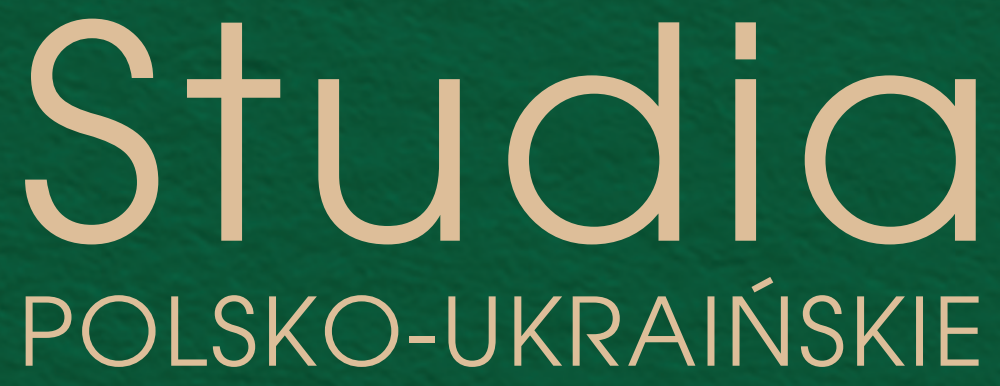




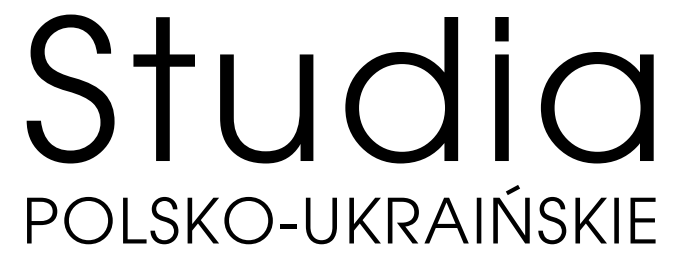




\section{Rada Naukowa}

prof. dr hab. Petro Bilous (Żytomierski Uniwersytet Państwowy im. Iwana Franki, Ukraina)

prof. dr hab. Giovanna Brogi (Uniwersytet w Mediolanie, Włochy)

prof. dr hab. Teresa Chynczewska-Hennel (Uniwersytet w Białymstoku, Polska)

dr hab. Mariusz Drozdowski (Uniwersytet w Białymstoku, Polska)

prof. dr hab. Piotr Fast (Uniwersytet Śląski, Polska)

dr Katarzyna Jakubowska-Krawczyk (Uniwersytet Warszawski, Polska)

prof. dr hab. Stefan Kozak (Uniwersytet Warszawski, Polska)

dr hab. Roman Mnich (Uniwersytet Warszawski, Polska)

prof. dr hab. Mirosław Nagielski (Uniwersytet Warszawski, Polska)

dr hab. Żaneta Nalewajk (Uniwersytet Warszawski, Polska)

prof. dr hab. Anna Nasiłowska (Polska Akademia Nauk, Polska)

prof. dr hab. Olha Novyk (Berdiański Państwowy Uniwersytet Pedagogiczny, Ukraina)

prof. dr hab. Vira Prosalova (Doniecki Uniwersytet Narodowy im. Wasyla Stusa

w Winnicy, Ukraina)

prof. dr hab. Rostyslav Radyshevskyi (Kijowski Uniwersytet Narodowy

im. Tarasa Szewczenki, Ukraina)

dr hab. Ludmila Siryk (Uniwersytet Marii Curie-Skłodowskiej, Polska)

prof. dr hab. Oksana Slipushko (Kijowski Uniwersytet Narodowy

im. Tarasa Szewczenki, Ukraina)

prof. dr hab. Hanna Skrypnyk (Narodowa Akademia Nauk Ukrainy, Ukraina)

prof. dr hab. Frank E. Sysyn (Uniwersytet Alberty, Kanada)

prof. dr hab. Mykola Tymoshyk (Kijowski Narodowy Uniwersytet Kultury

i Sztuki, Ukraina)

prof. Larysa Vakhnina (Narodowa Akademia Nauk Ukrainy, Ukraina)

prof. dr hab. Alicja Wołodźko-Butkiewicz (Uniwersytet Warszawski, Polska)

dr hab. prof. UMCS Ihor Nabytovych (Uniwersytet Marii Curie-Skłodowskiej, Polska)

prof. dr hab. Frank E. Sysyn (Uniwersytet Alberty, Kanada)

prof. dr hab. Iryna Bondarevska (Uniwersytet Narodowy „Akademia

Kijowsko-Mohylańska", Ukraina)

mgr Denis Kaidalov (Uniwersytet Warszawski, Polska)

prof. dr hab. Andriy Danylenko (Uniwersytet Pace, USA)

dr Julija Dragojlović (Uniwersytet w Belgradzie, Serbia) 
Wydział Lingwistyki Stosowanej Pracownia Dziejów Polsko-Ukraińskich Stosunków Literackich

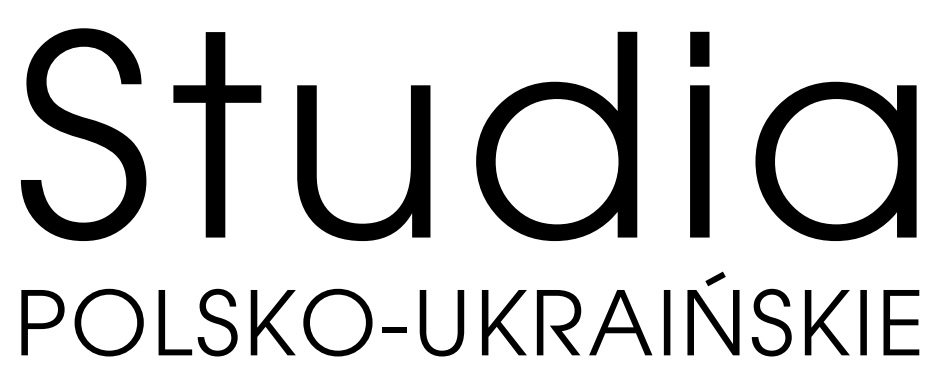

$\bullet$ 


\section{Redakcja}

prof. dr hab. Walentyna Sobol, Uniwersytet Warszawski, Polska - Redaktor Naczelna prof. dr hab. Teresa Chynczewska-Hennel, Uniwersytet w Białymstoku, Polska Zastępca Redaktora Naczelnego

Dawid Bzorek, Uniwersytet Warszawski, Polska - Sekretarz Redakcji

Adres Redakcji

Uniwersytet Warszawski

Wydział Lingwistyki Stosowanej

ul. Szturmowa 4

02-678 Warszawa

Projekt okładki i stron tytułowych

Dariusz Górski

Redaktor prowadzący

Dorota Dziedzic

Redaktor tekstów polskich i angielskich

Denys Kaidalov

Redaktor tekstów ukraińskich

Julia Kamińska

ISSN 2353-5644, e-ISSN 2451-2958

(c) Copyright by Wydawnictwa Uniwersytetu Warszawskiego 2021

(c) Copyright by Katedra Ukrainistyki, Wydział Lingwistyki Stosowanej UW 2021

Edycja elektroniczna jest wersją pierwotną czasopisma

Wszystkie artykuły w numerze 8/2021 publikowane są na zasadach licencji CC BY 3.0 PL. Pełna treść wzorca dostępna jest pod adresem: http://creativecommons.org/ licenses/by/3.0/pl/legalcode

Wydawnictwa Uniwersytetu Warszawskiego

00-838 Warszawa, ul. Prosta 69

wuw@uw.edu.pl

Dział Handlowy: tel. (48 22) 55-31-333

e-mail: dz.handlowy@uw.edu.pl

Księgarnia internetowa: www.wuw.pl

Skład, łamanie i wersja elektroniczna

Dariusz Górski

Druk: POZKAL

Numer ukazał się dzięki środkom Ministerstwa Nauki i Szkolnictwa Wyższego w ramach programu "Wsparcie dla Czasopism Naukowych”.

Redakcja nie ponosi odpowiedzialności za treść artykułów. 


\section{Spis treści}

\section{150-lecie Łesi Ukrainki}

Mariia Moklytsia, Роль рукописної спадщини Лесі Українки у підготовці повного зібрання їі творів . . . . . . . . . . . . . . . . . . . . . 11

Anna Choma-Suwała, Bojarynia Łesi Ukrainki w recepcji Józefa Łobodowskiego ......................... 21

Larysa Semeniuk, Tetiana Danyliuk-Tereshchuk, Народні балади Волині й Західного Полісся в записах Лесі Українки та членів ії родини: українсько-польські паралелі . . . . . . . . . . . . . . . . . 40

\section{W kręgu ego-dokumentów ukraińskich i polskich}

Tetiana Bovsunivska, Діарист як творець документальної медіації . Mirosław Nagielski, Diariusz wojny smoleńskiej Władysława IV (1633-1634) . . . . . . . . . . . . . . . . . . . . . . . . 69

Walentyna Sobol, Пилип Орлик сам про себе . . . . . . . . . . . . . . 85 Yaroslav Myshanych, Утвердження просвітницької естетики у щоденнику Петра Апостола . . . . . . . . . . . . . . . . . . . . . . . . 100

\section{Ego-materiały wobec wyzwań współczesności}

Teresa Chynczewska-Hennel, Fragment Dziennika Nepalskiego . . . . . . 117 Anna Horniatko-Shumylovych, Забуті імена: Василь Ткачук очима родичів й односельчан (на основі актуальних інтервю) . . . . . . 126 Eugeniusz Sobol, Skąd zło? Paradoksy rewolucji na Ukrainie O Wspomnieniach i Dziennikach Jewhena Czykałenki . . . . . . . . . . . . . . . 142

\section{Zagadnienia komparatystyki literackiej i filozoficznej}

Dawid Bzorek, Dyskurs życia prywatnego w dziennikach Filipa Orlika i Franciszka Il Rakoczego . . . . . . . . . . . . . . 
Oleksandr Siedin, Revealing the Rationality of Myth: Contribution of Bronislaw Malinowski . . . . . . . . . . . . . . . . . . . . . . .

Uliana Baran, The development of children's literature in Ukraine in the XX-XXI centuries . . . . . . . . . . . . . . . . . . . .

\section{Ad fontes}

Valerii Zema, Wizjonerstwo historyczne w tekstach pisarzy innowierczych

Mykola Krupach, «3 лупою літературного детектива» (До проблеми ідентифікації утаємничених текстів) . . . . . . . . . . . . . . . . . 212

\section{Artykuły recenzyjne}

Tadeusz Srogosz, Olha Morozova, Doslidzhennia istorii Ukrainy pershoi polovyny XX st. $v$ suchasnii polskii istoriohrafii: napriamky, kontseptsii, dyskusii / Badania historii Ukrainy pierwszej połowy XX wieku we współczesnej historiografii polskiej: trendy, koncepcje, dyskusje, Vydavnytstvo CzNU im. Petra Mohyly, Mikolaiv 2020, ss. 432

Mariusz R. Drozdowski, Historia wojen domowych w Polsce Alberta Viminy, w przekładzie Krzysztofa Żaboklickiego, pod redakcja, ze wstępem i komentarzami Teresy Chynczewskiej-Hennel, Instytut Badań nad Dziedzictwem Kulturowym Europy, Białystok 2017, ss. 284 . . . . . . . .

Yaroslav Polishchuk, Graniczne kształty ukraińskiego dramatu. Nataliia Maliutina, Ukraińska dramaturgia końca XIX i początku XX wieku. Redakcja naukowa Bogusław Bakuła, Agnieszka Matusiak, Toruń: Wydawnictwo Adam Marszałek, $271 \mathrm{~s}$

\section{Varia}

Ihor Stambol, Цвинтар Ольшани у Празі як місие пам'яті українців . 261 Tetiana Kachak, Дитинство в часи кризи XX-XXI cm. у літературі та культурі Центральної та Східної Європи . . . . . . . . . . . . . . . 274

Larysa Vakhnina, Myroslava Karatsub, Відзначення ювілею Максима Рильського в Інституті мистецтвознавства, фольклористики та етнології ім. М. Т. Рильського НАН України . . . . . . . . . . . . .

\section{In memoriam}

Teresa Chynczewska-Hennel, Profesor Ihor Skoczylas (5 IV 1967 - 20 XII 2020) 


\section{Contents}

\section{150-lecie Łesi Ukrainki}

Mariia Moklytsia, The role of Lesya Ukrainka's manuscript heritage in the preparation of her complete works. . . . . . . . . . . . . . . . .

Anna Choma-Suwała, Lesia Ukrainka's Boyarynia in reception of Józef Łobodowski. . . . . . . . . . . . . . . . . . . . . . .

Larysa Semeniuk, Tetiana Danyliuk-Tereshchuk, Folk ballads of Volyn and Western Polissya in the records of Lesya Ukrainka and her family members: Ukrainian-Polish parallels. . . . . . . . . . . . . . .

\section{W kręgu ego-dokumentów ukraińskich i polskich}

Tetiana Bovsunivska, Diarist as a creator of documentary mediation . . . Mirosław Nagielski, Diary of the Smolensk war of Władysław IV (1633-1634) . . . . . . . . . . . . . . . . . . . . . 69

Walentyna Sobol, Pylyp Orlyk about himself . . . . . . . . . . . . . . . 85

Yaroslav Myshanych, The establishment of the Enlightenment Aesthetics in the Diary of Peter the Apostle . . . . . . . . . . . . . . . . 100

\section{Ego-materiały wobec wyzwań współczesności}

Terasa Chynczewska-Hennel, The Fragment of Nepal Diary . . . . . . . . Anna Horniatko-Shumylovych, Forgotten names: Vasyl Tkachuk in the eyes of relatives and countrymen (based on recent interviews) . . . . 126 Eugeniusz Sobol, Where does evil come from? Paradoxes of revolution in Ukraine. On Diaries and Memoirs of Yevhen Chykalenko . . . . . . . . .

\section{Zagadnienia komparatystyki literackiej i filozoficznej}

Dawid Bzorek, Pylyp Orlyk and Francis II Rákóczi in comparative perspective ...................... 
Oleksandr Siedin, Revealing the Rationality of Myth: Contribution of Bronislaw Malinowski . . . . . . . . . . . . . . . . . . . . Uliana Baran, The development of children's literature in Ukraine in the XX-XXI centuries . . . . . . . . . . . . . . . . . .

\section{Ad fontes}

Valerii Zema, Historical Visionary in the Writings of Dissident Authors . . Mykola Krupach, "With a Magnifying Glass of a Literary Detective" (The problem of identifying clandestine texts) . . . . . . . . . . . . . 212

\section{Review articles}

Tadeusz Srogosz, The study of Ukrainian history in the first half of the 20th century in contemporary Polish historiography: trends, concepts and discussions, Vydavnytstvo CzNU im. Petra Mohyly, Mikolaiv 2020, pp. $432 \ldots \ldots \ldots \ldots \ldots \ldots \ldots \ldots \ldots \ldots \ldots \ldots \ldots \ldots$

Mariusz R. Drozdowski, The History of Civil Wars in Poland by Albert Vimina, in translation of Krzysztof Żaboklicki, editor, with introduction and comments of Teresa Chynczewska-Hennel, Instytut Badań nad Dziedzictwem Kulturowym Europy, Białystok 2017, pp. 284. . . . . .

Yaroslav Polishchuk, Border shapes of Ukrainian drama. Natalia Maliutina, Ukraińska dramaturgia końca XIX i początku XX wieku. Wydawnictwo Adam Marszałek, Toruń 2020, 271 p. . . . . . . . . . . . . . . . . .

\section{Varia}

Ihor Stambol, Olshany Cemetery in Prague as a place of memory of Ukrainians. . . . . . . . . . . . . . . . . . . . . . . . . . . 261

Tetiana Kachak, Childhood during the crisis of the XX-XXI centuries in literature and culture of Central and Eastern Europe . . . . . . . . . . 274

Larysa Vakhnina, Myroslava Karatsuba, Celebrating the anniversary of Maxim Rylsky at the Rylsky Institute of Art Studies, Folklore and Ethnology NAS, Ukraine . . . . . . . . . . . . . . . .

\section{In memoriam}

Teresa Chynczewska-Hennel, Professor Ihor Skochylas (5 IV 1967 - 20 XII 2020) . . . . . . . . . . . . . . . . . . . . . . . . . . 


\title{
Mariia Moklytsia
}

Lesya Ukrainka Volyn National University (Ukraine)

ORCID: 0000-0001-7984-4377

\section{Роль рукописної спадщини Лесі Українки у підготовці повного зібрання її творів}

\section{The role of Lesya Ukrainka's manuscript heritage in the preparation of her complete works}

\begin{abstract}
The article discusses the preparation of the academic edition of the complete works by Lesya Ukrainka for publication carried out by the staff of the Volyn National University named after Lesya Ukrainka (Lutsk, Ukraine), with the involvement of leading literary critics of Ukraine. The implementation of this large-scale project (a collection of 14 volumes) became possible due to the fact that the university is the owner of the electronic archive of Lesya Ukrainka. The manuscript heritage of the writer has become available for detailed study by a wide range of researchers, in addition to remotely. The article states that careful processing of manuscripts revealed many problems in studying Lesya Ukrainka's work, in particular, ideological interference in the process of publishing and interpreting manuscripts, especially draft manuscripts. The comparison of rough and clean autographs proved to be especially fruitful for commenting on texts, for an in-depth, and often completely new understanding of classical works. The organizers set a goal to fully reflect the handwritten legacy of Lesya Ukrainka in comments and notes. Unfortunately, not every work of the writer received such an in-depth discourse, because many texts are presented in the collection of first editions, as neither draft nor final manuscripts were found. But even the available autographs allow us to interpret the writer's manuscript heritage as a self-sufficient object of science, to which it is necessary to apply not only the textual and genetic method but also many other methods of modern literary criticism.
\end{abstract}

Keywords: Lesya Ukrainka, collected works, draft autograph, clean autograph, textology. 
Аналіз основних досліджень. Текстологічні дослідження досить широко представлені в науці про Лесю Українку, адже певний пієтет у ставленні до рукописів започаткувала сама письменниця, коли в останній рік свого життя упорядкувала наявні в неї рукописи (головним чином чернетки, адже чистові рукописи із редакцій майже не поверталися) і передала в архів Львівського відділення Наукового товариства імені Т. Шевченка (НТШ). Важко переоцінити і роль членів родини: матері, сестри Ольги, чоловіка Климента Квітки - у справі збирання і збереження рукописів. Шанобливе ставлення до цієї частини спадщини домінувало протягом 1920-х рр.: досі не втратили актуальності текстологічні зауваги Б. Якубського, Є. Ненадкевича, М. Драй-Хмари, А. Ніковського, А. Гозенпуда та інших дослідників. Львівський архів було описано і введено в науковий обіг у повоєнний час М. Деркач, О. Бабишкіним. Ціла когорта науковців вивчала рукописи, зібрані у фондах Інституту літератури ім. Т. Г. Шевченка Академії наук України: Г. Аврахов, О. Ставицький, Л. Мірошниченко, Т. Третяченко, Г. Гаджилова, В. Савчук та ін. Їхні скрупульозні фахові дослідження створили ту необхідну базу, яка дозволяє сьогодні вийти на якісно новий рівень вивчення, позбувшись ідеологічних упереджень, суттєво розширивши коло дослідників і застосувавши, окрім власне текстологічного, широку палітру сучасних наукових методів.

Постановка проблеми. У дослідженнях рукописів текстологічний підхід забирає левову частку зусиль дослідника і часто не залишає місця для наукових інтерпретацій чи нових гіпотез. Ідеологічне спрямування науки тривалий час не дозволяло науковцю виходити за межі фактажу й описовості. Якщо врахувати обмеження, актуальні й досі, у доступі до архіву, то картина проблем, пов'язаних з рукописною спадщиною Лесі Українки, набуде чітких обрисів. Давно назріла пора застосувати до рукописів нові підходи, переконливо показати, що для Лесі Українки надважливим був процес творчості, а не лише результат, як звично думали у радянські часи, думає й досі чимало науковців. 
Вперше за історію академічних видань письменника-класика, через 50-літню перерву, підготувала до друку повне зібрання творів Лесі Українки (14 томів) не наукова, а освітня установа: Волинський національний університет імені Лесі Українки. Таку підготовку здійснено внаслідок переконливої перемоги у національному конкурсі. Перемога, у свою чергу, стала можливою завдяки багатолітнім напрацюванням Інституту дослідження творчості Лесі Українки, створеного 2006 року на базі університету, за підтримки Інституту літератури Академії наук України. На той час в університеті вже було зібрано чимало матеріалів, присвячених творчості Лесі Українки. Але статус науково-дослідницької установи дозволив приступити до надважливого проєкту - переведення архіву Лесі Українки на електронні носії. Це складна і фінансово витратна робота, яка не всіма чиновниками і науковцями сприймалась як необхідна. Деякий час електронним архівом користувалися лише науковці Волинського університету, які готували індивідуальні наукові проєкти. Успішне завершення цих проєктів зумовлене також і можливістю вільного доступу до архіву письменниці. За десять років по творчості Лесі Українки було захищено 4 докторських (С. Кочерги, О. Вісич, Т. Левчук, С. Романова), 6 кандидатських дисертацій (О. Вісич, В. Савчук, С. Романова, Ю. Левчук, Т. Данилюк-Терещук, А. Радько). Автори цих досліджень стали осердям колективу, спроможного підготувати до видання повне зібрання творів Лесі Українки. Вихід такого зібрання важливий не лише з огляду на 150-літній ювілей Лесі Українки, а й через назрілу необхідність деконструкції радянських підходів до вивчення канонізованого класика.

Мета статті - наголосити, що рукописна спадщина письменника-класика, а саме рукописи Лесі Українки, - це безумовна цінність національної культури, важливий его-документ епохи, якому за радянських часів приділялась мінімальна увага. Досі знаходять науковці рукописи, що вважалися втраченими, досі тривають пошуки рукописів, які знаходяться у важкодоступних місцях зберігання (архіви Росії та інших країн світу), робляться відкриття, які змінюють усталені погляди. 
Виклад основного матеріалу. За десятиліття численних видань творів Лесі Українки в різних історичних умовах і з різними редакційними вимогами відбувся суттєвий відхід від першоджерела, а саме від автографів. Хоча у 1920-ті роки висококваліфіковані дослідники намагалися максимально уводити рукописи в коментарі, примітки і додатки (зокрема, йдеться про найбільш повне представлення рукописів у 12-томному виданні творів Лесі Українки «Книгоспілки» 1930 р.), домінування ідеологічного підходу зрештою підпорядкувало академізм. Коли упорядники академічних видань писали: «Подається за першодруком, звіреним з рукописом», це не означало, що будь-який дослідник отримає повне уявлення про початковий рукопис і всі зміни, які вносились у текст на різних етапах його оприлюднення. Ставлення до чорнових рукописів як до сирого, невідшліфованого, а отже й менш цінного, ніж остаточний варіант, матеріалу творчості, визначало підходи і впливало на результати. Початкові версії багатьох творів, особливо великих за обсягом, майже випали з поля зору дослідників на багато десятиліть, а якщо щось і оприлюднювалось, то лише фрагментарно, з настановою, що жодна публікація не повинна впливати на канонізований образ письменниці. Тому усебічне опрацювання рукописної спадщини із застосуванням сучасних підходів - це шлях назустріч Лесі Українці, це деконструкція всіх ідеологічних нашарувань, стереотипів й упереджень, які й досі (переважно непомітно, на несвідомому рівні) визначають бачення іiі творчості.

Чимало нового було відкрито науковцями Інституту дослідження творчості Лесі Українки під час підготовки 14-томного зібрання творів Лесі Українки 2021 року. Завдяки електронним копіям архіву рукописи стали доступними для ретельного опрацювання всіма учасниками проєкту. Членами колективу (а це близько 30 осіб) стали науковці з усієї України. Через умови карантину всі змушені були працювати дистанційно. Завдяки електронному архіву в упорядників з'явилась можливість у коментарях і примітках нового зібрання максимально повно показати історію створення кожного тексту. Робота з рукописами 
часто була надскладною, адже чистових рукописів Лесі Українки зберіглося дуже мало, а чернетки - це багато разів правлені тексти, писані олівцем, який майже втратив колір. I все ж копітка робота з рукописами дозволила максимально наблизитись до автентичного образу письменниці, декодувати багато незрозумілих через втручання ідеології аспектів, простежити всі етапи постання видатних творів Лесі Українки.

Як відомо, рукописи потребують чималих зусиль і витрат на їх збереження. Вразливість паперових носіїв і традиційних способів писання (для кінця XIX - початку XX ст. це олівець і чорнило, має значення також якість паперу) диктували певні умови зберігання і використання рукописів Лесі Українки. Доступ до цих матеріалів для ширшого кола дослідників завжди був утруднений. Історія збереження рукописів Лесі Українки це яскрава і водночас трагічна сторінка в історії української культури, сторінка, за якою криється чимало важливих процесів і тенденцій. Текстологічні дослідження дають максимально об’єктивовану картину творчого процесу письменниці. Але не менш важливими є проблеми осягнення культурно-історичного значення рукописної спадщини Лесі Українки, широкого кола питань художньо-естетичного змісту.

Погляд на рукописну спадщину Лесі Українки вертає нас на понад сто років назад, а це велика дистанція, яка багато аспектів творчості здатна деактуалізувати. Через вивчення рукописів зміцнюється неперервність глибокої традиції. Леся Українка переймалась проблемами, актуальність яких сьогодні лише загострилась: питання цінності національної мови для людини, яка прагне опанувати багато іноземних мов; питання приналежності української нації до європейської і водночас усвідомлення іiї унікальності та ін. У 14-томному зібранні творів Лесі Українки відбулося максимально повне оприлюднення рукописів Лесі Українки. Упорядники сподіваються, що це дасть безцінний матеріал для науковців із різних галузей.

Важливе значення має словник Лесі Українки, який складається з кількох суттєво різних лексичних груп. Рукописи 
яскраво демонструють поступове формування базового для світогляду й естетики набору концептів. Словник Лесі Українки насичений рідкісними діалектними словами і фразеологізмами української мови. Але його ж характерною ознакою є численні запозичення з багатьох іноземних мов. Не випадково Леся Українка посідає чільне місце серед творців української літературної мови: завдяки її зусиллям українська мова розширила словник і набула здатності наукового осмислення будь-яких проблем на найвищому рівні абстрагування. Словник Лесі Українки може розглядатися як зразок природного розширення літературної мови у процесі формування авторського стилю.

Застосування до рукописної спадщини таких сучасних методів, як структурно-семіотичний, наратологічний, міфокритичний, імагологічний, психоаналітичний, герменевтичний, рецептивний, інтертекстуальний та ін. дозволяє цілком інакше тлумачити багато ключових проблем творчості Лесі Українки. Варто підкреслити, що поглиблене вивчення рукописів при підготовці зібрання творів ще раз підтвердило попередньо висунуті і захищені науковцями гіпотези. Зокрема, семіотичний аналіз культурософських кодів Лесі Українки, здійснений С. Кочергою ${ }^{1}$, посприяв осмисленню концептосфери письменниці. Підхід на засадах естетики нон-фініто, застосований О. Вісич ${ }^{2}$, допоміг суттєво переоцінити роль чорнових рукописів. Культурно-історичний і генераційний підхід дозволив С. Романову показати ключову роль Лесі Українки у формуванні українського модернізму. ${ }^{3}$ Формалістичний і жанрологічний аналіз творів Лесі Українки у працях Т. Левчук ${ }^{4}$ посприяли формуванню спільних

${ }^{1}$ S. Kocherha, Kulturosofiia Lesi Ukrainky. Semiotychnyi analiz tekstiv, «Tverdynia», Lutsk 2010.

2 O. Visych, Estetyka non-finito u tvorchosti Lesi Ukrainky, «Tverdynia», Lutsk 2014.

${ }^{3}$ S. Romanov, Etyko-estetychna systema Lesi Ukrainky i natsionalnyi literaturnyi kontekst epokhy, Avtoreferat dys... doktora filolohichnykh nauk, 10.01.01 - ukrainska literatura; 10.01 .06 - teoriia literatury, Kyiv 2019.

${ }^{4}$ T. Levchuk, Fenomen literaturnosti, «Tverdynia», Lutsk 2018. 
критеріїв для коментування текстів. Дисертаційні текстологічні і генетичні напрацювання В. Савчук 5 і А. Радько 6 були успішно залучені у процесі підготовки зібрання творів Лесі Українки.

Психоаналітичний метод, який тривалий час застосовує до творчості Лесі Українки авторка цієї статті7, також актуалізувався під час опрацювання рукописів для повного зібрання творів. Зокрема, йдеться про чорновий рукопис драми Лесі Українки «Камінний Господарь», майже вдвічі більший за обсягом від чистового рукопису. Частково цей рукопис був опрацьований при підготовці 12-томного видання творів Лесі Українки 1930 р. $€$. Ненадкевичем, ${ }^{8}$ але пізніше, разом із самим репресованим зібранням, майже зник з поля зору і читачів, і науковців. Чому письменниця так суттєво скоротила початковий текст - не просте питання. Сама Леся Українка в листі до О. Кобилянської пояснила скорочення так: «Так воно не $\epsilon$, бо хтось дійсно mit Todesverachtung9 працював дні і ночі, працював 3 гарячкою в крові, а скінчивши, хорував певно більше, ніж хорують жінки

${ }^{5}$ V. Savchuk, Dolia lystiv Lesi Ukrainky, «Tverdynia», Lutsk 2011.

${ }^{6}$ A. Radko, Zibrannia tvoriv Lesi Ukrainky u vydavnychomu proekti «Emihratsiinoi "Knyhospilky"» [w:] Lesia Ukrainka v diaspornomu literaturoznavstvi. Nimetsko-ukrainski zviazky, zb. nauk. pr., t. 11, Miunkhen-Ternopil 2019, s. 194-203.

7 M. Moklytsia, Estetyka Lesi Ukrainky (kontekst yevropeiskoho modernizmu), Universytet im. Lesi Ukrainky, Lutsk 2011; M. Moklytsia, Psykhoanalitychnyi naratyv u liubovnykh istoriiakh Lesi Ukrainky («Blakytna troianda», "Lisova pisnia») [w:] „KELM. Nauka, oświata, prawo, zarządzanie”, Łódź 2018, nr 4(24), s. 184-193; M. Moklytsia, Psykhoanalitychnyi naratyv u tvorchosti Lesi Ukrainky (na prykladi dramy «U pushchi») [w:] Volyn filolohichna: tekst $i$ kontekst, zb. nauk. pr., Lutsk 2018, vyp. 26: Lesia Ukrainka i personalii epokhy, s. 139-156; M. Moklytsia, Psykhoanalitychnyi naratyv u drami Lesi Ukrainky "Kaminnyi hospodar» [w:] Okrylenist slovom: zb. nauk. pr. na poshanu prof. Stepana Khoroba, Ivano-Frankivsk 2019, s. 50-61; M. Moklytsia, Psykhoanalitychnyi naratyv yak literaturoznavchyi termin (proiektsiia na dramaturhiiu Lesi Ukrainky [w:] Aktualni problemy literaturoznavchoi terminolohii, naukovyi zbirnyk, Rivne 2020, vyp. 3, s. 40-44.

${ }^{8}$ Ye. Nenadkevych, Ukrainska versiia svitovoi temy pro Don Zhuana v istorychno-literaturnii perspektyvi [w:] Lesia Ukrainka, Povne zibrannia tvoriv, t. 11, «Knyhospilka», Kharkiv-Kyiv 1930, s. 7-42.

9 Зі зневажанням смерті (нім.) - М. М. 
після породу, а прийшовши ледве не ледве до здоровя, працював знову над уже скінченою драмою <...> щ о б зробити ії короткою (вона була чи не двічі довша, ніж тепер), щоб сконцентрувати iї стиль, наче якусь сильну ессенцію, зробити його ляконічним, як написи на базальті, увільнити його від ліричної млявости та розволіклости <..> уняти сюжет в короткі енергічні риси, дати йому щось “камінного”. Я не люблю багато мережання та візерунків на статуях, а ся драма повинна була нагадувати скульптурну групу - такий був мій замір, а про виконання судити не можу». ${ }^{10}$

Це пояснення загалом вкладається в той тип творчого процесу, який передбачає орієнтацію на досконалий результат. Для Лесі Українки така мотивація властива: вона дуже суттєво допрацьовувала свої тексти. Але водночас численні зізнання (в тому числі і в наведеному листі) Лесі Українки вказують, що головний процес іiі творчості відбувався в ірраціональній частині психіки: твори писалися швидко, стан організму був надзвичайно хворобливий і дуже виснажував авторку. Раціональне сприйняття майже не функціонувало. Це означає, що процес творчості переважно був або сублімаційний (за концепцією 3. Фройда), або візійний (за концепцією К.-Г. Юнга), тобто з мінімальною участю раціональної сфери. Натомість наступна стадія роботи над текстом була повністю підпорядкована раціо. Отже, зіставлення чорнового і чистового варіантів одного тексту не лише виявляє різницю чи спосіб удосконалення, а й значно глибші прошарки творчого процесу. Привертає увагу не просто правка (пошук більш точних чи більш яскравих словосполучень), а часте викреслювання чималих фрагментів, які не містять очевидних недоліків (оскільки драматургія Лесі Українки віршована, формальний аспект завжди впадає в око). У драмі «Камінний Господарь» вилучені не лише рядки і строфи, а й цілі сцени, внаслідок чого змінилась диспозиція кожного персонажа, а також їхні характери. Наприклад, у початковому варіанті драми вагоме

${ }^{10}$ Lesia Ukrainka, Lysty: 1903-1913, «Komora», Kyiv 2018, s. 672. 
місце посідала Донна Соль. Вилучено великий фрагмент за участю Донни Соль і їі ревнивого чоловіка на балу в Альваресів, скорочено сцени з'ясування стосунків Донни Соль і Дон Жуана, сцена втручання Донни Соль у діалог Дон Жуана з Командором і чимало іншого. Внаслідок цих вилучень Донна Соль стала епізодичним персонажем. Робота над кожним персонажем драми, сутність якої увиразнюється завдяки зіставленню чорнового і чистового рукописів, - це окрема тема. Застосування різних наукових методів до рукописів дозволить суттєво поглибити розуміння цього і багатьох інших творів Лесі Українки.

Висновки. Леся Українка, опрацьовуючи текст, народжений стихійно (ірраціонально), вилучає ті елементи, які містять надто прямі вказівки на біографічні події, намагається максимально опосередковувати й універсалізувати особисто пережите. Важко переоцінити значення рукописів при вивченні творчості віддаленого у часі класика. 3 огляду на трагічну історію України, особливо радянський період, коли було знищено безліч безцінних надбань культури, можна стверджувати, що наявність великої кількості рукописів Лесі Українки - це виняткова цінність, яка вимагає не лише збереження, а й поглибленого і систематичного вивчення. Повне представлення рукописів у новому зібранні творів дозволить піднести на новий рівень вивчення творчості Лесі Українки. Разом з тим окреслено низку проблем, пов'язаних з подальшими пошуками рукописів та їх вивченням.

\section{References}

Kocherha S., Kulturosofiia Lesi Ukrainky. Semiotychnyi analiz tekstiv, "Tverdynia», Lutsk 2010.

Levchuk T., Fenomen literaturnosti, «Tverdynia», Lutsk 2018.

Moklytsia M., Estetyka Lesi Ukrainky (kontekst yevropeiskoho modernizmu), Universytet im. Lesi Ukrainky, Lutsk 2011.

Nenadkevych Ye., Ukrainska versiia svitovoi temy pro Don Zhuana v istorychno-literaturnii perspektyvi [w:] Lesia Ukrainka, Povne zibrannia voriv, t. 11, «Knyhospilka», Kharkiv-Kyiv 1930, s. 7-42. 
Savchuk V., Dolia lystiv Lesi Ukrainky, «Tverdynia», Lutsk 2011.

Radko A., Zibrannia tvoriv Lesi Ukrainky u vydavnychomu proekti «Emihratsiinoi "Knyhospilky"» [w:] Lesia Ukrainka v diaspornomu literaturoznavstvi. Nimetsko-ukrainski zviazky, zb. nauk. pr., t. 11, Miunkhen-Ternopil 2019, s. 194-203.

Romanov S., Etyko-estetychna systema Lesi Ukrainky i natsionalnyi literaturnyi kontekst epokhy, Avtoreferat dys... doktora filolohichnykh nauk, 10.01.01 ukrainska literatura, 10.01.06 - teoriia literatury, Kyiv 2019.

Ukrainka Lesia, Lysty: 1903-1913, «Komora», Kyiv 2018.

Ukrainka Lesia, Kaminnyi Hospodar, Arkhiv Instytutu literatury im. T. H. Shevchenka Akademii nauk Ukrainy, f. 2, od. zb. 19 (chystovyi avtohraf), f. 2, od. zb. 784 (chornovyi avtohraf).

Visych O., Estetyka non-finito u tvorchosti Lesi Ukrainky, «Tverdynia», Lutsk 2014. 


\section{Anna Choma-Suwała}

Maria Curie-Skłodowska University in Lublin (Poland)

ORCID: 0000-0001-8909-7993

\section{Bojarynia Łesi Ukrainki w recepcji Józefa Łobodowskiego}

\section{Lesya Ukrainka's Boyarynia in reception of Józef Łobodowski}

\section{Abstract:}

In the interwar period, Józef Łobodowski was one of the few who became interested in the work of Lesya Ukrainka. In the 1930s, he translated her drama Forest Song. Unfortunately, the war prevented its publication and the prepared materials were lost. Łobodowski's translation output also included a fragment of the drama Boyarinya, which appeared in the 32nd Polish-Ukrainian Bulletin in 1938. It is worth emphasizing that Łobodowski proved to be known not only as a translator, but also as a literary critic. He has written a number of articles on Ukrainian literature. Among them, two of them, published in the "Polish-Ukrainian Bulletin": Lesya Ukrainka and Works of Lesya Ukrainka (On the 25th Anniversary of Death - 1913-1938) in 1933 and 1938, respectively, deserve special attention. The discussed translation is largely an example of dynamic equivalence. In them, the translator draws attention to semantic adequacy, but does not give up the poeticisation of the text.

Key words: Ukrainian literature, translation, interwar period, Lesya Ukrainka, Józef Łobodowski.

Łesia Ukrainka (Łarysa Kosacz-Kwitka, 1871-1913) debiutowała bardzo wcześnie, jej dwa wiersze Konwalia (Конвалія) i Safona (Сафо) zostały opublikowane na łamach lwowskiego czasopisma „Zoria” („Зоря”) w 1884 roku, kiedy autorka miała niespełna trzynaście lat. Wkrótce wyszły drukiem także trzy zbiory jej poezji: Na skrzydłach pieśni (На крилах niсень, 1893), Myśli i marzenia (Думи і мріï, 1899) 
i Recenzje (Відгуки, 1902). Trudno zatem uwierzyć, że jej twórczość na początku XX wieku była niemal zupełnie nieznana polskiemu czytelnikowi. W Polsce pojawiały się jedynie pojedyncze przekłady, a pierwsze z nich autorstwa ukraińskiego tłumacza Sydora Twerdochliba opublikowano w Antologii współczesnych poetów ukraińskich w 1910 roku. O wzmożonym zainteresowaniu twórczością Łarysy Kosacz możemy mówić dopiero w okresie powojennym. W 1941 roku pojawiły się przekłady autorstwa m.in. Stanisława Jerzego Leca i Zuzanny Ginczanki, a w latach 1956-1971 Leopolda Lewina, Władysława Boruńskiego, Kazimierza Andrzeja Jaworskiego, Tadeusza Chróścielewskiego i Floriana Nieuważnego. ${ }^{1}$

Usprawiedliwieniem małego zainteresowania spuścizną ukraińskiej pisarki wydają się słowa ostatniego z nich:

Istnieją w kulturze europejskiej twórcy, których dzieło przesiąknięte na wskroś pierwiastkami narodowymi jest tak organicznie związane z kulturą rodzimą, że mimo niezaprzeczalnej wielkości i oryginalności z trudem wychodzą poza krąg własnych odbiorców, zdumionych rzekomą niewrażliwością i brakiem zainteresowania cudzoziemców. ${ }^{2}$

W okresie międzywojennym Józef Łobodowski był jednym z nielicznych, którzy zainteresowali się dorobkiem Łesi Ukrainki. Translatorska działalność lubelskiego poety w dwudziestoleciu międzywojennym zasługuje na szczególną uwagę, ponieważ okres ten był dla niego najbardziej owocny. W latach trzydziestych pracował między innymi nad przekładem dramatu Łesi Ukrainki Leśna pieśń (Лicoвa nісня). O czym wspomina w artykule Ze wspomnień ukrainofila:

Przeniósłszy się na stałe do Warszawy, zacząłem pisać dużo do „Wschodu” i „Myśli Polskiej”, a przede wszystkim do „Biuletynu Polsko-Ukraińskiego”, z którym już współpracowałem poprzednio. Sporo tłumaczyłem, przygotowując powoli obszerną antologię poezji ukraińskiej od „Słowa o pułku

1 Zob. W. Sobol, Recepcja twórczości Łesi Ukrainki w Polsce, tłum. M. Zambrzycka, „Przegląd humanistyczny”, 2011, nr 4 (427), s. 82-83.

${ }^{2}$ F. Nieuważny, Fenomen Lesi Ukrainki [w:] Łesia Ukrainka, Pieśn lasu, Państwowy Instytut Wydawniczy, Warszawa 1989, s. 5. 
Ihora" aż po Olżycza i Antonycza. Świetny poeta ukraiński, Jewhen Małaniuk zachęcił mnie do przełożenia fantastycznego dramatu Łesi Ukrainki „Leśna pieśń”. Przekład, nad którym praca wlokła się dłuższy czas, przerywana przez uboczne, głównie zarobkowe zajęcia, został ukończony w lecie 1939, i jedynie wybuch wojny przeszkodził wystawieniu tego pięknego utworu, nieustępującego literacko ani „Balladynie”, ani „Snowi nocy letniej”. ${ }^{3}$

Niniejszy artykuł jest próbą prezentacji zachowanych przekładów i przybliżenia polskiemu czytelnikowi wkładu Łobodowskiego w popularyzację twórczości Łesi Ukrainki w Polsce międzywojennej.

Wart podkreślenia jest fakt, że Łobodowski dał się poznać nie tylko jako tłumacz, ale także krytyk literacki. Spod jego pióra wyszło szereg artykułów poświęconych literaturze ukraińskiej. Wśród nich na szczególną uwagę zasługują dwa opublikowane w „Biuletynie Polsko-Ukraińskim": Łesia Ukrainka ${ }^{4}$ i Twórczość Łesi Ukrainki (W dwudziestopięciolecie śmierci - 1913-1938)5 odpowiednio w 1933 i 1938 roku.

W swoich tekstach bardzo pochlebnie wyrażał się o dokonaniach Łesi Ukrainki stawiając ją na równi z Tarasem Szewczenką:

Zdumiewająco olbrzymi dorobek literacki (siedem wielkich tomów) tej niezwykłej w literaturze światowej kobiety-pisarki, pod względem formy, jest logicznym rozwinięciem linji poetyckiej: liryka - poemat - dramat. Oprócz doskonałości stylu, plastyczności obrazów, doskonałego języka i mistrzowskiego opanowania formy dramatycznej, - najważniejszem i najbardziej zdumiewającem w twórczości Łesi Ukrainki jest wewnętrzna energia utworów, płomień prawdziwej poezji i prawie niedościgniony (poza Szewczenką) w literaturze ukraińskiej prometejski patos narodowy. ${ }^{6}$

Możliwe, że właśnie to było przyczyną zainteresowania twórczością Łesi Ukrainki, bo jak wiadomo w okresie warszawskim (1933-1936)

3 J. Łobodowski, Przeciw upiorom przeszłości, Test, Lublin 2015, s. 133.

${ }^{4}$ Ed. K. [J. Łobodowski], Łesia Ukrainka, „Biuletyn Polsko-Ukraiński”, 1933, nr 12, s. 1-2.

5 J. Łobodowski, Twórczość Łesi Ukrainki (W dwudziestopięciolecie śmierci - 19131938), „Biuletyn Polsko-Ukraiński”, 1938, nr 32, s. 345-346.

6 Ed. K. [J. Łobodowski], Łesia Ukrainka, s. 1. (Zachowano oryginalną pisownię). 
Łobodowski zbliżył się do kół zrzeszający ukraińską emigrację, tłumacząc poezję ukraińską korzystał z pomocy Pawła Zajcewa, Natalii Lywickiej-Chołodnej i Jurija Łypy. Z kolei ugruntowaniem jego poglądów politycznych był okres wołyński i współpraca ze związkiem „Prometeusz”. Otwarcie bronił idei dążeń narodowowyzwoleńczych Ukrainy. Tym przekonaniom podporządkowywał także wybory translatorskie. Wybierał utwory poetów ukraińskich, dla których słowo było bronią w walce o niepodległość.

$\mathrm{W}$ ten nurt idealnie wpisuje się poemat Bojarynia (Бояриня), który znalazł się w translatorskiej spuściźnie Łobodowskiego. Jego fragment pojawił się w 32. numerze „Biuletynu Polsko-Ukraińskiego” w 1938 roku. $^{7}$

Bodźcem do napisania dramatu była tęsknota za rodzinnym krajem. Autorka potrzebowała zaledwie trzech dni (27-29 kwietnia 1910 roku), aby przebywając w Egipcie przelać na papier swoją nostalgię. Jest to obok Pieśni lasu jeden $\mathrm{z}$ dwóch wyjątkowych utworów w dorobku Łarysy Kosacz. Podobnie jak „dramat-feeria” jest poświęcony Ukrainie, a konkretnie jednemu $\mathrm{z}$ najcięższych momentów w jej historii - okresowi tzw. „ruiny”, który przypadał na lata 1657-1687. W dramacie Bojarynia, Łesia Ukrainka namawia, aby nie opuszczać ojczyzny, nie stronić od ojczystego języka i zwyczajów, ale robić wszystko, co możliwe, by być prawdziwym ukraińskim patriotą. W jednej z recenzji Józef Łobodowski słusznie zauważa, że:

Gniew poetki wobec objawów małoduszności, sprzedajności czy wręcz zdrady narodowej musiały szukać cenzuralnych form wyrazu, co najłatwiej było osiągnąć za pomocą przerzucania się w analogiczne epoki dziejowe. Stąd też historyczne utwory poetki prawie zawsze mają jakiś wydźwięk aktualnościowy, prawie zawsze pod maską dawno nieistniejących ludzi i przebrzmiałych wypadków ukazują żywy, bolesny problem współczesnej ukraińskiej rzeczywistości. $^{8}$

7 Łesia Ukrainka, Bojarzynia. Fragment poematu dramatycznego, przeł. z ukr. J. Łobodowski, „Biuletyn Polsko-Ukraiński”, 1938, nr 32, s. 347-348.

8 J. Łobodowski, Twórczość Łesi Ukrainki..., s. 346. 
Autorka dość adekwatnie odwzorowała nie tylko ducha epoki, styl myślenia przedstawicieli różnych klas, ale także szczegóły obyczajów, zachowania, ubioru, wnętrza itp. Utwór ukazuje jej światopogląd, jej ból, refleksję nad perspektywą narodową, chęć ukazania przyczyn i skutków upadku Ukrainy.

Kwestią ostro postawioną w dramacie jest problem dwóch tradycyjnych kultur, dwóch zupełnie różnych mentalności. Łobodowski podkreśla, że

[w] utworze tym poetka wysunęła w drastycznej formie sprawę zasadniczego antagonizmu dwóch kultur: moskiewskiej i ukraińskiej (rzecz dzieje się w wieku XVII). „Bojarzyni” są przeważnie przemilczani, w sowieckich omówieniach twórczości Łesi Ukrainki najczęściej nawet nie wymieniani, i oczywiście nie ma mowy o wystawieniu tego dramatu na jakiejkolwiek scenie teatralnej dzisiejszej Ukrainy. ${ }^{9}$

Za życia Łesi Ukrainki Bojarynia nie wyszła drukiem. Jej pierwsze wydanie pojawiło się w czasopiśmie „Рідний край” w 1914 roku. Krytyka przyjęła je obojętnie. Prawydanie ukazało się jako oddzielna książka w 1918 roku w Jekaterynosławiu (dzisiejszy Dniepr). Według Pauliny Andrijczuk-Danczuk,

Znamy tylko jedną recenzję jekaterynosławskiego wydania książki z 1918 roku (o czym wspomina Draj-Chmara). Autor tej recenzji W. Straszkewycz charakteryzuje poemat Łesi Ukrainki z punktu widzenia literackiego i dramatycznego: „Sztuka jest napisana poetycko, w delikatnych, łagodnych tonach i podczas czytania tworzy nastrój, ale kiedy poemat dramatyczny zabrać do teatru, to wydaje mi się, że w spektaklu będzie odczuwalny brak ruchu scenicznego". ${ }^{10}$

Kompozycja utworu składająca się z pięciu części zbudowana jest niemal w całości w formie dialogów. Fabuła utworu skoncentrowana jest wokół uczucia jakie zrodziło się między bojarem Stepanem (pochodzenia ukraińskiego) i Oksaną, która w imię miłości

\footnotetext{
9 J. Łobodowski, W stulecie Łesi Ukrainki, „Kultura”, 1971, nr 6, s. 115.

10 Cyt. za: P. Andriichuk-Danchuk, Natsionalne pytannia $w$ dramatychnii poemi „Boiarynia” Lesi Ukrainky, Dzherzi Syti, Niu Dzherzi 2007. - Moje tłumaczenie.
} 
opuszcza ojczyznę i wyrusza za ukochanym do Moskwy. Rozwój akcji ukazuje życie głównej bohaterki w Moskwie, jej niemożność przyzwyczajenia się do roli żony bojara. W dramacie ukazane są portrety psychologiczne głównych bohaterów na tle etnopsychologii. Mychajło Draj-Chmara uważa, że: „element psychologiczny w tym poemacie przesłania to, co historyczne"11. Widoczne są w niej dwa główne motyw nostalgii i zdrady. Pierwszy z nich łączy się z postacią głównej bohaterki, której towarzyszy poczucie tęsknoty za ojczyzną. Drugi natomiast wiąże się z postacią Stefana i jest widoczny już na samym początku utworu w konflikcie na tle patriotycznym między Iwanem Perebijnym i moskiewskim bojarem. W dalszej części dramatu przybiera on postać sporu między Oksaną i Stefanem, stając się przyczyną nieporozumień na gruncie rodzinnym.

Charakteryzując twórczość Łesi Ukrainki, Łobodowski słusznie zauważa, że najczęściej występującym w niej motywem jest motyw zdrady narodowej i bezczynności w obliczu zagrożenia:

Motyw ten niejednokrotnie łączy się z podkreślonym poprzednio motywem nostalgii na obczyźnie. Gdy w poemaciku dramatycznym „Bojarzyni” na tle dobrze naszkicowanego życia w Moskwie XVII wieku występuje motyw narodowej pasywności, czytelnik doskonale wyczuwa, że pisząc o ukraińskiej „ruinie”, poetka miała na myśli najbardziej bolesne i dręczące strony współczesnej rzeczywistości. ${ }^{12}$

Łobodowski przybliżył polskiemu czytelnikowi fragment ostatniej części poematu, w której bardzo słaba Oksana „z zapadniętymi oczami i chorym rumieńcem na twarzy" wychodzi do ogrodu. Gdy zasypia, Stepan potajemnie omawia z matką, jak ją leczyć i dochodzi do wniosku, że jedynym rozwiązaniem jest jej powrót na Ukrainę.

Możemy się tylko domyślać co było przyczyną wyboru tego właśnie fragmentu dramatu, ale znając translatorskie upodabnia Łobodowskiego trudno się temu dziwić. Jego zdaniem, Łesia Ukrainka

11 M. Drai-Khmara, Boiarynia [w:] Lesia Ukrainka, Bojarynia. Dramatychna poema, Vydannia Orhanizacyi Zhinok Ukrayiny, Toronto 1971, s. 77.

12 J. Łobodowski, Twórczość Łesi Ukrainki..., s. 346. 
[...] była ukraińską nacjonalistką. Ale nie w tym ujemnym znaczeniu, jakie słowu „nacjonalizm” nadały późniejsze, a głównie nasze czasy. W mrocznej nocy carskiego ucisku, jaka w młodych latach i Ukrainki zapadła nad Ukrainą, należała do tych, na razie nielicznych, którzy głosili contra spem spero i wzywali do odrodzenia historycznej świadomości narodowej, tyle raz przygłuszanej. ${ }^{13}$

Przetłumaczony fragment zaczyna się słowami Oksany, która w marzeniach ciągle powraca do obrazu utraconej ojczyzny, młodości spędzonej w ojcowskim sadzie otulonym poświatą księżyca:

Оксана:

Се ти, Степане?.. Бач, мені приснилось, що місяць ясно-ясно засвітив у батьковім садочку...

С т еп ан:

(удавано веселим голосом):

Місяць, люба?

Се дивно, бо якраз на тебе сонце!

О ксана:

Що ж, може, там ясніше світить місяць, ніж тут сонце...

С те п ан:

Не журись, Оксано, ось хутко знов побачим, як там світить і сонечко, і місяць на Вкраїні.

Оксан а:

Се ж як? Хіба умру? Тоді запевне душа полине...14
Oks a na:

To ty, Stepanie? Popatrz, śniło mi się, że jasny księżyc olśnił sad, ojcowski sad kochany...

Ste p a n:

(udaje wesołość)

Księżyc, luba?

To dziwne, bo nad nami właśnie słońce! Oks a na:

Cóż, może tam jaśniejszy księżyc nocą niż tutaj słońce...

Ste pan:

Nie smuć się, Oksano, niedługo znów ujrzymy, jak jaśnieją księżyc i słońce w naszej Ukrainie.

Oksana:

Jakże to? - Chyba umrę... Pewnie wtedy poleci dusza... ${ }^{15}$

Tłumaczowi udało się w pełni odwzorować zawarte w pierwowzorze dialogi, ich nastrój i klimat. Przekład można zatem uznać za

13 J. Łobodowski, W stulecie Łesi Ukrainki, s. 115.

14 Lesia Ukrainka, Tvory v 12-ty tomakh, t: 8: Dramy, za red. D. Yakubovskoho, Tyshchenko\&Biloys Vydavnycha Spilka, New York 1954, s. 150. (Pozostałe fragmenty oryginału pochodzą z powyższego źródła, numery stron podane w nawiasie).

15 Łesia Ukrainka, Bojarzynia. Fragment poematu..., s. 347. (Cytaty przekładu pochodzą z tego samego źródła, numery stron podane w nawiasie). 
w pełni adekwatny, akceptowalny z punktu widzenia jego pragmatyki. Jest on zrozumiały dla polskiego odbiorcy i oddaje pierwotne zamierzenie autora. Najwięcej trudności translatorskich dostarczyło Łobodowskiemu słowotwórstwo i nacechowane emocjonalnie deminutywy. Użyte w oryginale formy rzeczowników typu: caдочкy, сонечко, річок, братчикам, батенька są wyznacznikiem emосjоnalnego zabarwienia lub doprecyzowania użytego w oryginale znaczenia wyrazu. Rezygnacja z nich pozbawiła przekładu specyficznego ukraińskiego kolorytu. I jak podkreśla Wojtasiewicz: „[...] formy zdrobniałe i rubaszne bardzo często nie tylko wskazują przedmiot, o który chodzi, ale jednocześnie wyrażają stosunek uczuciowy do niego"16. W poemacie pojawiają się również charakterystyczne dla języka ukraińskiego, zwłaszcza stylizowanego, słowne powtórzenia. Najczęściej są one utworzone przez użycie tego samego przymiotnika lub przysłówka i niosą ze sobą wysoki stopień manifestacji danej cechy lub właściwości, np. ясно-ясно. Występują także jako powtarzające się czasowniki wyrażające intensyfikację akcji: сuдiв-сudis.

W tego typu translacjach tłumacz zmuszony jest do poszukiwania odpowiednich ekwiwalentów leksykalnych lub w sytuacji ich braku - wykazania się umiejętnościami interpretacyjnymi oraz inwencją twórczą. Brak tego typu umiejętności wpływa negatywnie na efekty translacji. Na ten temat wypowiada się bardzo autorytatywnie Olgierd Wojtasiewicz: „W tej dziedzinie niedostateczność takiej interpretacji ujawnia się chyba najwyraźniej. W najlepszym razie zubaża ona i upraszcza sprawy bardzo zróżnicowane w oryginale, a ponadto w wielu wypadkach zawodzi całkowicie". ${ }^{17}$

Tłumacz ma przed sobą niejako dwie możliwości: albo przenieść elementy ukraińskiej kultury i niepowtarzalny koloryt oryginału do przekładu, albo dokonać takich transformacji, by poemat był zrozumiały dla polskiego czytelnika. Łobodowski przyjął strategię drugą i zmodyfikował, a niekiedy całkowicie wyeliminował, elementy

\footnotetext{
16 O. Wojtasiewicz, Wstęp do teorii ttumaczenia, Tepis, Warszawa 2005, s. 45. 17 Ibidem, s. 43.
} 
oryginału, zastępując je słowami przystosowanymi do przyzwyczajeń odbiorcy docelowego. Tego typu udomowienia widoczne są w następujących frazach: що місяць ясно-ясно засвітив / у батьковім садочку - że jasny księżyc olśnit sad, / ojcowski sad kochany; ось хутко знов побачим, як там світить/ $і$ сонечко, $і$ місяць на Вкраїні - niedługo znów ujrzymy, jak jaśnieja / księżyc i słońce $w$ naszej Ukrainie.

Jednocześnie chcąc zachować pierwotny ladunek emocjonalny tłumacz posłużył się przymiotnikami i przysłówkami: sad kochany, słońce w naszej Ukrainie siedziałeś długo, mitych braci, stara szabla, które konkretyzują znaczenie i nadają wypowiedzi bardziej osobisty charakter. Dzięki takiemu zabiegowi dochodzi do rozszerzenia fraz, częstych inwersji i substytucji, które prowadzą do znaczących przesunięć $\mathrm{w}$ sferze sensów.

Innym problemem ujawnionym $\mathrm{w}$ dramacie Bojarynia oraz $\mathrm{w}$ innych utworach Łesi Ukrainki jest przeciwstawianie się pojęciu „niewolnictwo”. Nie ma na świecie wartości przewyższającej wartość wolności, bo tylko ten, kto wyzwolił się z wewnętrznej niewoli, może marzyć o uwolnieniu swoich sąsiadów, swojego ludu, swojej ojczyzny. Różnemu podejściu do pojęcia wolności poświęcony został kolejny fragment dialogu głównych bohaterów. Stepan łączy wielkie nadzieje $\mathrm{z}$ wyjazdem na spokojną, jego zdaniem, Ukrainę. Jest przekonany, że uzyska pozwolenie od cara. Dla Oksany te słowa są powodem wielkiego rozgoryczenia:

C теп пн:

Цар пустить. Вже ж тепера на

Вкраїні утихомирилося.

О к с а а (2оcmpo):

Як ти кажеш?

Утихомирилося? Зломилась воля, Україна лягла Москві під ноги, се мир по-твоєму ота руїна?

Отак і я утихомирюсь хутко в труні... (s. 150)
Stepan:

Car puści! - Przecież dziś

na Ukrainie spokojnie wszystko.

Oks a n a:

Jakżeś to powiedział?

Wszystko spokojnie? Wolność przełamana, u nóg moskiewskich legła Ukraina

i to dla ciebie spokój - ta ruina? Oh, tak i ja się wkrótce uspokoję w zacisznej trumnie... (s. 347) 
Jak słusznie podkreśla Mychajło Draj-Chmara w poemacie Łesia Ukrainka oprócz źródeł historycznych wykorzystuje również znane motywy literackie:

W ostatnim akcie poematu Stepan mówi Oksanie, że poprosi cara o pozwolenie na jej pielgrzymkę do Kijowa. Podróż do Kijowa w celu zwiedzania pieczar i oddawania czci świętym to motyw, który często pojawia się w naszej literaturze. Na przykład w wierszu Szewczenki „Najemnica” Hanna udaje się z pielgrzymką do Kijowa. W powieści Kulisza „Czarna rada” Czerewań $\mathrm{z}$ rodziną jedzie na pielgrzymkę do Kijowa. ${ }^{18}$

Przetłumaczony dialog, podobnie jak oryginał, jest przepełniony niepokojem i emocjonalną impulsywnością. Bohaterowie prowadzą bardzo ożywioną rozmowę, w której pojawia się obraz uciemiężonej, zrujnowanej Ukrainy. Polskie tłumaczenie niepozbawione jest licznych transformacji wynikających z przyjętej przez Łobodowskiego strategii adaptacji. Już w pierwszym wersie zauważamy substytucję i amplifikację, które oddają występującą w tekście źródłowym wypowiedź. Tłumacz, w miejsce trudnych do przekładu form: одживешся, утихомирилося wprowadza czytelne dla odbiorcy polskiego rozbudowane substytuty: do zdrowia wrócisz, spokojnie wszystko, których znaczenie nie zawsze jest zbieżne $\mathrm{z}$ oryginałem. Co ciekawe Łobodowski nie jest wierny swoim wyborom, сzasownik утихомирилося przekazuje na różne sposoby, oprócz przytoczonego wyżej ekwiwalentu używa również jego odwrotności wszystko spokojnie. Natomiast formę pierwszej osoby liczby pojedynczej утихомирюсь tłumaczy jako uspokoje się, natomiast pochodny wyraz втихомирилось zastępuje rzeczownikiem spokój. Zatem można wysnuć wniosek, że znając najbliższy oryginałowi odpowiednik świadomie $z$ niego rezygnuje dynamizując tym samym tekst przekładu. Jedne $\mathrm{z}$ ciekawszych substytucji i amplifikacji występują w następujących wersach: Toż przecie Moskwa słońca nie zasłoni, / ni w gaju drzew rodzimych nie powal / rzek nie wysuszy (Москва ж не може заступити сония, /

${ }^{18}$ M. Drai-Khmara, Boiarynia [w:] Lesia Ukrainka, Bojarynia, op. cit., s. 85. - Moje tłumaczenie. 
зв'ялити гаю рідного, зсушити/ річок веселих). Pierwszy z nich jest również przykładem archaizacji. Drugi i trzeci z kolei można uznać za rodzaj konkretyzacji treści.

Proces polegający na wprowadzeniu wyrazów i zwrotów reprezentujących dawne słownictwo jest powszechny w procesie powstawania przekładu. W tłumaczeniu Łobodowskiego znajdujemy kilka przykładów archaizacji i wprowadzenia elementów potoczności. Pojechać razem $z$ toba umyślitem (Надумав я поїхати з тобою); Czemu tak do mnie mówisz? Aż mi dziwno! (Мені аж дивно! Що се ти говориш?); teraz gdy nastat “spokój”, radbyś szedt (menep, як “втихомирилось", ти їдем). Jak wynika z powyższych zestawień są one autorskim pomysłem tłumacza. Krzysztof Lipiński podkreśla, że

[...] archaizmy są zakorzenione w kulturze każdego narodu i dlatego rzadko dochodzi do sytuacji, że archaizm w języku oryginału posiada swój odpowiednik w języku przekładu. Tego typu substytucje mogą pojawić się również jako element stylizacji językowej oddającej np. koloryt epoki, wówczas dochodzi do wykorzystania archaizmów języka docelowego. ${ }^{19}$

Kolejny fragment utworu odnosi się do jednego z wcześniej naświetlonych problemów zdrady narodowej, postrzeganym przez pryzmat pasywności Stepana, który grzejąc się w blasku Moskwy nie zrobił nic dla ocalenia ojczyzny. Jeśli jednak spojrzymy na dramat Bojarynia jak na utwór alegoryczny. W osobie Stepana możemy odnaleźć przedstawiciela ukraińskiej inteligencji końca XIX początku XX wieku, który utracił poczucie własnej tożsamości narodowej i przyjął cudzą kulturę zrzekłszy się własnej. Oksana jest natomiast członkiem społeczeństwa, który walczył o prawo do samostanowienia narodu ukraińskiego, protestował, ale trafiwszy w sieć zaborczych działań caratu traci siły i kona na obczyźnie. ${ }^{20}$

Konflikt między tymi dwoma postawami życiowymi widoczny jest w dialogu Stepana i Oksany, która kategorycznie odmawia wyjazdu na Ukrainę i dziwi się pomysłowi męża, aby jej towarzyszyć:

19 K. Lipiński, Vademecum tłumacza, Idea, Kraków 2000, s. 105-106.

${ }^{20}$ M. Drai-Khmara, Boiarynia [w:] Lesia Ukrainka, Bojarynia, op. cit., s. 71-72. 
Оксан а (розпаливиись, підводиться):

А я дивую, ти 3 яким лицем збираєшся з'явитись на Вкраїні! Сидів-сидів у запічку московськім, Поки лилася кров, поки змагання велося за життя там на Вкраїні, - тепер, як “втихомирилось”, ти їдеш того ясного сонця заживати, що не дістали руки загребущі, та гаєм недопаленим втішатись. На пожарині хочеш подивитись, чи там широко розлилися ріки від сліз та крови?.. (с. 150-151)
Oks a n a (zapala się):

I mnie też dziwno, z jakim ty obliczem dziś się wybierasz w naszą Ukrainę! Siedziałeś długo w Moskwie na przypiecku, póki się lała krew, dopóki walka za ukraińską wolność się toczyła - teraz gdy nastał „spokój”, radbyś szedł korzystać z tego słońca, co go ręce drapieżne z nieba ukraść nie umiały, i gajem cieszyć się niedopalonym. $\mathrm{Na}$ pogorzeli pragniesz się rozejrzeć, czy tam szeroko rzeki się rozlały od łez i krwi... (s. 347)

Polski przekład tego fragmentu poematu nie poddaje się jednoznacznej ocenie. Niektóre fragmenty tekstu zostały przetłumaczone dokładnie, w innych Łobodowski wyraźnie odstępuje od treści oryginału, niekiedy skraca i uprasza go, innym razem dodaje pojedyncze wyrazy, uszczegóławiając zawarty w tekście źródłowym przekaz. Zastosowane przez tłumacza modyfikacje nie wpływają znacząco na ogólny wydźwięk utworu. Już w pierwszym wersie widoczna jest bardzo udana substytucja leksykalna Zmiłuj się, Oksano! (Що се ти, Оксано?). W drugim oprócz wspomnianej wcześniej archaizacji mamy przykład inwersji w obrębie wersu. Do najbardziej udanych ekwiwalencji należy zaliczyć kolejne wersy: Siedziałeś długo w Moskwie na przypiecku (Сидів-сидів у запічку московськім); za ukrainska wolność się toczyła (велося за життя там на Вкраӥнi); korzystać z tego słońca, co go ręcel drapieżne z nieba ukraść nie umiały (того ясного сония заживати, що не дістали руки загребуші).

W artykule Strapienia tłumacza, przywodząc postulat Peipera o równomiernym rozmieszczeniu „napięć lirycznych”, Łobodowski pisze, że przy tłumaczeniu poematu zastosowanie owego postulatu nie jest możliwe, gdyż należy, przede wszystkim, wydobyć z oryginału elementy najbardziej istotne: 
Tłumacz jak kartograf w krajobrazie, powinien orientować się według głównych punktów triangulacyjnych. Jeśli nie straci z pola widzenia żadnego z nich, przekład ma szansę wypaść zadawalająco. Inaczej mówiąc, chodzi o wydobycie elementów najbardziej istotnych, nieraz, gdy zajdzie potrzeba, kosztem drugorzędnych. ${ }^{21}$

$\mathrm{W}$ dramacie jednym $\mathrm{z}$ istotnych elementów jest kolejny fragment, w którym Oksana porównuje siebie i Stepana do zardzewiałej szabli przywartej do pochwy. Jak zauważa Draj-Chmara: „Ten sam obraz istnieje również $\mathrm{w}$ wierszu Lesi Ukrainki Tovaryshtsi na spomyn (Przyjaciótce na pamiątkę)". 22

$\mathrm{O}$ к ан а

(дивиться на свою й Степанову рукu):

От, здається, руки чисті, проте все мариться, що їх покрила не кров, а так... немов якась іржа... як на старих шаблях буває, знаєш?

(Пускає його руку і лягає знов.

Говорить повільніше, млявіше, 3 перервами.)

у батенька була така шаблюка... вони іiі закинули... ми з братом знайшли... в війну побавитись хотіли... не витягли... до піхви прикипіла... заржавіла... Отак і ми з тобою... зрослись, мов шабля 3 піхвою... навіки... обоє ржаві... (c. 151-152)
O ks a n a:

(ogląda ręce swoje i Stepana)

Oh, zdaje się, czyste, a jednak ciągle mi się przywiduje, że je okryła, nie, nie krew... lecz rdza... wiesz, taka rdza, jak na szabliskach starych? (puszcza rękę i kładzie się. Mówi powolniej, z przerwami).

Była u ojca taka stara szabla w komorze zarzucona... myśmy z bratem ją odszukali... w wojnę chcąc się bawić... lecz próżno... rdzawa... do pochwy przywarła... nie można było wyjąć. Tak i my... zrośnięci razem, niby szabla z pochwą... oboje rdzawi...(s. 347)

Polskie tłumaczenie tego fragmentu, jak większość translacji Łobodowskiego, jest ukierunkowane na odbiorcę. W opartym na zasadzie ekwiwalencji przekładzie tłumacz zachował zawarte $\mathrm{w}$ oryginale obrazy i symbole. Trudne fragmenty zmodyfikował lub

${ }^{21}$ J. Łobodowski, Strapienia tłumacza, „Kultura”, 1956, nr 6, s. 47-48.

22 Ibidem, s. 86. 
zastąpił zrozumiałymi dla polskiego czytelnika substytutami, ale nie do końca pozbawił przekład augmentatywu шаблюка. Zrezygnował $\mathrm{Z}$ adekwatnego odpowiednika w wersie: Była u ojca taka stara szabla (У батенька була така шаблюка), ale użył zgrubienia w poprzedzającym te słowa fragmencie: że je okryła, nie, nie krew... lecz rdza.../ wiesz, taka rdza, jak na szabliskach starych? (не кров, а так... немов якась іржа.../ як на старих шаблях буває, знаєш?), podkreślająс dodatkowo przekaz przymiotnikiem.

Analiza kolejnego fragmentu tłumaczenia skłania do wniosku, że translacja jest w znacznym stopniu przykładem ekwiwalencji dynamicznej, przekazuje bowiem główną myśl zawartą w oryginale. Na drugim planie stoją natomiast dosłowność, kolejność wyrazów, ścisła wierność strukturze gramatycznej itd. Tłumacz większą uwagę poświęca naturalnemu odwzorowaniu utworu w języku odbiorcy, dowodzi tego poniższe zestawienie oryginału z polska wersją językową:

С тепан :

Ти, Оксано, вмієш

Зарізати словами без ножа.

Нас доля так уже скарала тяжко, що, певне, й Бог простить усі гріхи. Хто кров із ран теряв, а ми із серця. Хто засланий, в турму замкнутий був, а ми несли кайдани невидимі.

Хто мав хвилини щастя в боротьбі, а нас важка, страшна душила змора, і нам не вділено було снаги

ту змору подолати...

Оксан а (спокійніше й тагідніше, ніж досі):

Так, се правда.

Але ніхто сього не зрозуміє, поки ми живі. Отже, треба вмерти. (c. 152)
Stepan:

Ty, Oksano, umiesz, bez noża zarżnąć bezlitosnym słowem... Nas los tak pokarał nadto ciężko, że pewnie Bóg przebaczy każdy grzech. Kto $z$ rany broczył krwią, a my spod serca. Kto na zesłaniu za kratami siedział, a myśmy nieśli więzy niewidoczne.

Kto chwilę szczęścia zaznał wpośród walk, a nas dusiła straszna, ciężka zmora i nie sądzone było, nie pisane tej zmory zmóc na zawsze...

Oks an a: (spokojniej $i$ łagodniej, niz dotychczas)

Tak, to prawda.

Ale tej prawdy nikt nie wyrozumie, póki żyjemy. $\mathrm{Na}$ to umrzeć trzeba. (s. 347)

Lubelski poeta wprowadził w przekładzie liczne zmiany: amplifikacje, inwersje, substytucje, nie zawsze zachowując pierwotne 
znaczenie, mimo to w gruncie rzeczy przekazuje kluczowe obrazy, wstępujące w tekście źródłowym: Ty, Oksano, umiesz,/ bez noża zarżną́ bezlitosnym słowem...(Ти, Оксано, вмієш/ Зарізати словами без ножа.); Bodajbym lepiej ja te słowa mówit (Ой, краще 6 я тобі таке казав!); a nas dusiła straszna, ciężka zmoral i nie sądzone było, nie pisanel tej zmory zmóc na zawsze (а нас важка, страшна душила змора,/ і нам не вділено було снаги/ ту змору подолати); Ale tej prawdy nikt nie wyrozumie (Але ніхто сього не зрозуміє). Na szczególną uwagę zasługują bardzo ciekawe kompensacje, które są przykładem użycia przestarzałych, wychodzących z użycia słów: zmóc (zwyciężyć kogoś w walce) i wyrozumieć (zrozumieć, pojąć, analizując rozumowo dojść do wniosku). ${ }^{23}$ Ich użycie w pełni odpowiada pierwotnemu zamysłowi autorki, oddając znaczenie ukraińskich zwrotów.

Tłumacz dużo uwagi poświęca adekwatności semantycznej, ale nie rezygnuje z upoetycznienia prostych niekiedy sformułowań: Kto $z$ rany broczyt krwia, a my spod serca./ Kto na zesłaniu za kratami siedziat (Хто кров із ран теряв, а ми із серия./ Хто засланий, в турму замкнутий був).

Warto nadmienić, że wyrazem poważnej ingerencji Łobodowskiego w tekst oryginału jest znaczna transformacja lub całkowita redukcja tekstów pobocznych, które w utworze Łesi Ukrainki są nie tylko wskazówkami dla wystawiających dramat, ale także stanowią samodzielną wypowiedź. Precyzują one zachowanie bohaterów, odwzorowują rzeczywistość i komentują świat przedstawiony. Rezygnacja $\mathrm{z}$ dosłownego tłumaczenia didaskaliów pozbawia cytowany fragment intymnego charakteru, dzięki czemu akcent zostaje położony na wypowiedź bohaterów, a nie ich zachowanie:

О ксан а (підводиться і прихиляє його до себе):

$\mathrm{Hi}$, любий, ти на світі потрібніший, тобі ще є про що й про кого дбати.
Oksana:

Nie, luby, tyś na świecie potrzebniejszy, potrzebna będzie innym twa opieka.

23 Słownik języka polskiego pod red. W. Doroszewskiego, https://sjp.pwn.pl/doroszewski [20.12.2020]. 
Борцем не вдався ти, та після бою подоланим подати пільгу зможеш, як ти не раз давав... На бойовиську не всі ж померли, ранених багато... поможеш їм одужати, то, може, колись там... знов зібравшися до бою, вони тебе згадають добрим словом а як і ні - не жалуй, що поміг.

(Сидять якийсь час мовчки, обнявuucb). (c. 153)
Bojownik z ciebie żaden, lecz po walce pokonanemu umiesz przyjść z pomocą, jak nie raz przedtem... Na pobojowisku nie wszyscy padli, iluż leży rannych... Do życia wrócić pomóż im, to może kiedyś tam... znów na walkę wyruszając, pamięcią wdzięczną imię twe otoczą... a jeśli nie... nie żałuj, żeś pomagał... (siedzi chwile w milczeniu) (s. 378)

Łobodowskiemu kolejny raz udało się zachować kontekst danej sytuacji, a zastosowane substytucje oddały sens tekstu źródłowego, mimo że w utworze znajdują się takie środki językowe, jakich brakuje w języku polskim: potrzebna będzie innym twa opieka (moбi me $\epsilon$ про що й про кого дбати). Znaczące jest również to, że niektóre kompensacje w niczym nie ustępują wartości oryginału: pamięcia wdzięczna imię twe otocza (вони тебе згадають добрим словом). Tłumacz zadbał również o adekwatne umieszczenie wielokropku, który przerywając tok wypowiedzi akcentuje zawarte w niej emocje.

Ostatni fragment tłumaczenia jest swego rodzaju testamentem głównej bohaterki. Oksana przekazuje Stepanowi swoją ostatnią wolę. Zdaje sobie sprawę $\mathrm{z}$ tego, że nie jest on typem bohatera, ale chce uratować go przed mianem zdrajcy. Nie widzi już zbawienia dla siebie, idąc do domu zwraca się ku zachodzącemu słońcu, które zobaczy jej ukochaną Ukrainę, z prośbą aby ją pozdrowiło:

Оксана:

Ходім.

(Спираючись на руку Степанову, іде до будинку. Не доходячи

рундука, спиняється

і обертається, дивлячись на соние, що вже зникає за обрієм.)

Добраніч, сонечко! Ідеш на захід... Ти бачиш Україну - привітай!

(c. 154)
Oks ana :

Chodźmy!

(Wspierając się na ręku Stepana, idzie do domu. Nie dochodzac do ganku zatrzymuje się i odwraca, patrzac na zachodzące słońce, które już znika za horyzontem).

Dobranoc słońce! - ty na zachód idziesz. Zobaczysz Ukrainę - więc powitaj!

(s. 378) 
Jeśli chodzi o frazę „сонце вже навзаходi”, to w polskim tłumaczeniu Józef Łobodowski dokonał bardziej poetycznego przekłady, wykorzystując metaforę: Patrz, stońce chyli się na zachód.

Podsumowując pobieżną analizę, należy podkreślić, że przekłady Łobodowskiego, choć nieliczne, miały na celu zainteresowanie polskiego czytelnika twórczością Łesi Ukrainki. Był nie tylko tłumaczem jej dramatów, ale także wierszy. Fragmenty trzech z nich Dym (Дим), Gdzieście słowa rozglośne, przepadly bez śladu... (Де поділися ви, голоснії слова...) і Na motyw z Mickiewicza (На мотив з Міцкевича) zaczynający się od słów: $Я$ не кохаю тебе $і$ не прагну дружиною cmamu (Nie, ja nie kocham! Nie pragnę, abyś mnie nazwat swa żona) zachowały się w nr. 6 powojennej paryskiej „Kultury” z 1971 roku. Spolszczone wiersze wpisują się w nurt translatorskich wyborów tłumacza. Lubelski tłumacz dostrzegł ich potencjał i doceniał twórczość Łesi Ukrainki, o czym świadczą jego słowa:

Znaczenie i stanowisko Łesi Ukrainki w literaturze ukraińskiej polega (...) $\mathrm{z}$ jednej strony na tym, że wprowadzając do poezji i dramatu europejską szerokość horyzontów, pierwsza zdobyła się na ogólnoludzką problematykę, a zwłaszcza na stawianie i artystyczne rozwiązywanie zagadnień psychologicznych. Miłość, poświęcenie, obowiązek, zdrada własnej osobowości, wierność ojczyźnie - znalazły w jej twórczości interpretację tyleż artystyczną, co pozbawioną prowincjonalnego prymitywizmu. ${ }^{24}$

Translacje Łobodowskiego są bardzo zbliżone do oryginałów, a dokonane transformacje służą pragmatyce tłumaczenia i przejrzystości odbioru. Omówiona translacja jest w dużej mierze przykładem ekwiwalencji dynamicznej. Przekład zachowuje swoisty koloryt pierwowzorów. Tłumacz zwraca w nim uwagę na adekwatność semantyczną, ale nie rezygnuje z upoetycznienia tekstu. Łobodowski tworzy oryginalne metafory, stosuje liczne środki kompensacji, wprowadza archaizmy i udomowienia, wszystko po to, aby wywołać w polskim czytelniku doświadczenie odbioru podobne do reakcji adresata pierwotnego. Mimo licznych zmian, braku jednorodności

${ }^{24}$ J. Łobodowski, Twórczość Łesi Ukrainki..., s. 346. 
i konsekwencji w podejmowanych wyborach, jego przekład zasługuje na ocenę pozytywną, zdołał bowiem w atrakcyjny sposób przekazać polskiemu czytelnikowi kunszt Łesi Ukrainki.

\section{References}

Andriichuk-Danchuk P., Natsionalne pytannia w dramatychnii poemi „Boiarynia” Lesi Ukrainky, Dzherzi Syti, Niu Dzherzi 2007.

Drai-Khmara M., Boiarynia [w:] Lesia Ukrainka, Bojarynia. Dramatychna poema, Vydannia Orhanizacyi Zhinok Ukrayiny, Toronto 1971, s. 59-88.

Ed. K. [J. Łobodowski], Łesia Ukrainka, „Biuletyn Polsko-Ukraiński”, 1933, nr 12, s. $1-2$.

Lesia Ukrainka, Tvory v 12-ty tomakh, t: 8: Dramy, za red. D. Yakybskoho, Tyshchenko\&Biloys Vydavnycha Spilka, Nyu-York 1954.

Lipiński K., Vademecum tłumacza, Idea, Kraków 2000.

Łesia Ukrainka, Bojarzynia. Fragment dramatycznego, przeł. z ukr. J. Łobodowski, „Biuletyn Polsko-Ukraiński”, 1938, nr 32, s. 347-348.

Łobodowski J., Przeciw upiorom przeszłości, Test, Lublin 2015.

Łobodowski J., Twórczość Łesi Ukrainki (W dwudziestopięciolecie śmierci - 19131938), „Biuletyn Polsko-Ukraiński”, 1938, nr 32, s. 345-346.

Nieuważny F., Fenomen Łesi Ukrainki [w:] Łesia Ukrainka, Pieśn lasu, Państwowy Instytut Wydawniczy, Warszawa 1989, s. 5-20.

Słownik języka polskiego pod red. W. Doroszewskiego, https://sjp.pwn.pl/doroszewski/wyrozumiec;5521847.html [20.12.2020].

Sobol W., Recepcja twórczości Łesi Ukrainki w Polsce, tłum. M. Zambrzycka, „Przegląd humanistyczny”, 2011, nr 4 (427), s. 78-92.

Wojtasiewicz O., Wstęp do teorii tłumaczenia, Tepis, Warszawa 2005. 


\title{
Larysa Semeniuk
}

Lesya Ukrainka Volyn National University (Ukraine)

ORCID: 0000-0002-6619-9695

\section{Tetiana Danyliuk-Tereshchuk}

Lesya Ukrainka Volyn National University (Ukraine)

ORCID: 0000-0002-9677-4929

\section{Народні балади Волині й Західного Полісся в записах Лесі Українки та членів їі родини: українсько-польські паралелі}

\section{Folk ballads of Volyn and Western Polissya in the records of Lesya Ukrainka and her family members: Ukrainian-Polish parallels}

\begin{abstract}
:
The article highlights research findings of the ballad plots from the folklore repertoire of Volyn and Western Polissia of the end of the 19th century revealed in the records of Lesya Ukrainka and her family members (Mykhailo and Olha Kosach, Olena Pchilka) and also known in close Polish analogues of those days. The ballads, recorded by the Kosachs, are dominated by stories of family relationships and conflicts caused by marriage without love, long-term separation (the topic of incest), and the mother's interference in a marital relationship that leads to murder, poisoning, and other tragic situations. A comparative analysis of ballad variants in two languages allows identifying not only the geographical area of spreading of ballad plots in the folklore of neighbouring nations, the specifics of plots, motifs, images, but also points to the features of the Ukrainian and Polish folklore works interaction on the borderlands. In the ballads, belonging to the International Ballad Fund, the plot-lines about wanderings of a dishonoured girl, the incest-related topics, mother's poisoning of her daughter-in-law and son, about the death of a servant because of his/her mistress' caprices, the wife's murder of her husband are typical and similar to various languages. Ukrainian and Polish versions of the ballad-songs have similar features in the structural components of the lyrics, describing mostly life tragic collisions, everyday situations, dialogues
\end{abstract}


of the characters, and artistic details. Despite the affinity of plots, images, artistic means of expression, multilingual texts offer different, often radically different ways of resolving personal and family conflicts. In addition, they are often marked with national colouration and reflect the features of local life, the social life realities of the Ukrainians, Poles, and other ethnic groups. The study has revealed that national attribution of the characters, their specific national names (especially in the Polish texts), polarization on the principle of ours/a stranger, a native/foreigner are the most noticeable features. The Ukrainian and Polish plots express mental ethnic stereotypes of folklore carriers, in particular, regarding women's role in family and society.

Keywords: Lesya Ukrainka, the Kosach family, Volyn, Western Polissia, folk ballad, version, plot, Ukrainian-Polish borderland.

Народна балада належить до найбільш поширених жанрів традиційного пісенного репертуару жителів Волині й Західного Полісся. Популярним жанром вона також була й залишається в Польщі. У цьому переконують фольклорні записи 3 цих теренів, зроблені в XIX-XX ст. такими знаними збирачами фольклору, як 3. Доленга-Ходаковський, М. Костомаров, О. Кольберг, П. Чубинський, Д. Булгаковський, О. Малинка, К. Квітка, Ф. Колесса та К. Мошинський. Частина з них увійшла до видання українських народних балад, упорядкованого О. Деєм та А. Ясенчук ${ }^{1}$. До збирання та публікації баладного репертуару Волині й Західного Полісся активно долучилася й Леся Українка та члени іiі родини - мати Олена Пчілка, сестра Ольга, брат Михайло.

Попри те, що фольклористичний доробок Лесі Українки та iї оточення вже не раз ставав об’єктом наукових студій (праці К. Квітки, М. Деркач, П. Одарченка, Л. Яросевич та ін.), народнобаладний пісенний матеріал з теренів українсько-польського пограниччя, збережений завдяки небайдужості відомої родини

${ }^{1}$ Balady. Kokhannia ta doshliubni vzaiemyny, uporiad. O. Dei, A. Yasenchuk (teksty), A. Ivanytskyi (melodii), Nauk. dumka, Kyiv 1987; Balady. Rodynno-pobutovi stosunky, uporiad. O. Dei, A. Yasenchuk (teksty), A. Ivanytskyi (melodii), Nauk. dumka, Kyiv 1988. 
Драгоманових-Косачів, спеціально не вивчався. Як переконують дослідження Л. Вахніної2, такий аналіз особливо важливий в аспекті етнокультурних контактів, адже розташування цих регіонів на перетині різних етнічних культур (української, білоруської, польської) наклало відбиток на їхній пісенний репертуар, зокрема на народнобаладну творчість.

Метою статті $\epsilon$ аналіз баладних сюжетів з фольклорного репертуару Волині й Західного Полісся в записах Лесі Українки та членів її родини і близьких польських варіантів задля виявлення особливостей українсько-польської фольклорної взаємодії на пограниччі.

Прикметно, що вже в XIX ст. до фіксації та збереження традиційного баладного фонду волинян та поліщуків поряд із українцями активно долучилися білоруські та польські дослідники: 3. Доленга-Ходаковський, Р. Зенькевич, О. Кольберг, Д. Булгаковський, М. Довнар-Запольський, пізніше - К. Мошинський та ін. Спостерігаючи за процесом побутування народнопісенної творчості на Волині й Західному Поліссі, українські й польські фольклористи відзначали природний нахил жителів цих країв до виконання пісень гостро драматичного та трагічного звучання. Так, польський письменник і вчений Ю. Крашевський, який тривалий час жив на Поліссі й добре знав його традиційну культуру, звернув увагу на такий факт: коли трапляється нещастя, то переживання поліщука часто висловлюється співом. «Найдивніше, - писав він, - що в ці особливі хвилини печалі жінки, замість того щоб говорити і плакати, неустанно сумно співають» ${ }^{3}$.

Українська письменниця і дослідниця традиційної культури Олена Пчілка, коментуючи фольклорні матеріали з Полісся

${ }^{2}$ L. Vakhnina, Folklor ukraynsko-polskoho pohranychia [w:] Hranytsy, kultury y ydentychnosty. Etnolohyia vostochnoslavianskoho pohranychia, Moskva 2012, s. 254-261; L. Wachnina, Folklor ukraińsko-polskiego pogranicza (na przykładzie ballady) [w:] Polska-Ukraina. Pogranicze kulturowe i etniczne, Wrocław 2008, s. $227-240$.

3 J. Kraszewski, Wspomnienia Wołynia, Polesia i Litwy, t. 1, Wilno 1840, s. 139. 
і Волині, зазначала: «Те, що записи мої зроблені на Поліссі, надає ім особливого значення, оскільки населення цієї місцевості, що губиться у лісах і віддалених від новіших впливів куточках, краще зберегло стару пісенність» ${ }^{4}$. Серед колядок, записаних Пчілкою, є зразки календарно приурочених пісень-балад.

Запрошуючи $Ф$. Колессу до збирання і вивчення поліського фольклору, польський дослідник К. Мошинський указував у своєму листі від 28 лютого 1932 року, що в усній поетичній творчості цього регіону можна виявити багато пам'яток «дуже давніх часів»5. Це підтвердила їхня спільна фольклорна експедиція на Полісся, матеріали якої склали збірку поліських народних пісень ${ }^{6}$. Помітне місце в ній займають балади.

Знайомство Косачів із волинсько-поліською фольклорною традицією припадає на 80-90-ті pp. XIX ст. Записи, зроблені Оленою Пчілкою, Михайлом, Ларисою і Ольгою Косачами, переважно на Звягельщині (в Миропіллі, Жабориці, Полонному) та на Ковельщині (Колодяжне, Білин, Скулин, Волошки та ін.). Ольга Косач-Кривинюк зауважила великий інтерес Лесі Українки до пісенного фольклору краю: «У Колодяжному Леся виконала з деякою допомогою брата Михайла велику етнографічну роботу: записала од різних колодяженських людей та від одної жінки з села Біліня (у нас ії звали “Білінкою”, і я не пам’ятаю, як вона звалася) дуже багато пісень»7. Сама авторка цих рядків теж цікавилася народними піснями та вела їхні записи. До рукописного збірника 1890-1893 рр., або т. зв. «колодяженського зошита» увійшло дві баладних пісні в записах Ольги та

${ }^{4}$ Olena Pchylka, Ukraynskye koliadky (tekst volynskyi), «Kyevskaia staryna», t. 80, nr 1, 1903, s. 154-155.

${ }^{5}$ Z lystuvannia Filareta Kolessy, «Narodna tvorchist ta etnohrafiia», nr 4, 1971, s. 56.

${ }^{6}$ Muzychnyi folklor z Polissia u zapysakh F. Kolessy ta K. Moshynskoho, uporiadkuv. ta komentari S. Hrytsy, Kyiv 1996.

${ }^{7}$ O. Kosach-Kryvyniuk, Oznaiomlennia Lesi Ukrainky $z$ narodnoiu tvorchistiu [w:] T. Skrypka, Spohady pro Lesiu Ukrainku, u 2-kh t., t. 1, Tempora, Kyiv 2017, s. 128. 
шість - у записах Лариси Косач. Про труднощі фіксації таких текстів Леся Українка зізнавалася в листі до М. Драгоманова від 21.XII.1891 р. (2 січня 1892) з Колодяжного. Надсилаючи дядькові «давно обіцяних пісень», вона писала, що їх «справді трудно було дістати, бо вони мало співаються і то більше межи старими людьми» ${ }^{8}$.

Початком 90-х pp. XIX ст. датовані також спільні фольклорні записи Лариси і Михайла Косачів, зроблені, як уточнює К. Квітка, «безпосередньо від волинських селянок і селян» 9 . Цікаву інформацію про це містить «Літературна газета» за 4 квітня 1941 року: «Відомо, що з допомогою свого брата вона [Леся Українка - Л. С., Т. Д.-Т.] збирала пісні та билини в селах Ковельського і Луцького повітів» ${ }^{10}$. Автор замітки (в публікації «Наш кор[еспондент]») міг помилитися 3 жанровим означенням («билина»); ймовірно, тут ідеться про думи чи балади, які записували Лариса і Михайло Косачі. Згадки про такі записи є в їхній переписці 1890-1894 pр., листах Лесі Українки до М. Драгоманова цього періоду. Так, відомо що Лариса Косач радилася з дядьком щодо записаного разом із братом:

Чи не прийняли 6 Ви од мене деяких етнографічних матеріалів, може, вони Вам на що здадуться? Бо я їх не вмію до пуття довести. На пробу Міша оце мусить Вам послати скілька волинських «баллад», що я йому диктовала, як він був тут у мене; прийміть їх, коли вони куди-небудь судні (Лист Лесі Українки від 16(28).VII.1891 р. з Євпаторії до Драгоманова М. П. $)^{11}$.

Серед нині відомих пісенних записів Лариси і Михайла Косачів, чільне місце посідають балади: усього 21 текст, 3 них

${ }^{8}$ Lesia Ukrainka. Lysty 1876-1897, uporiadkuvannia V. Prokip, peredmova V. Aheievoi, Komora, Kyiv 2016, s. 166-167.

${ }^{9}$ Narodni melodii. Z holosu Lesi Ukrainky zapysav i uporiadyv Klyment Kvitka, ch. I-II, Kyiv 1917-1918, s. 1.

${ }^{10}$ Lesia Ukrainka: dokumenty i materialy: 1871-1970, vidp. red. S. Pilkevych, Naukova dumka, Kyiv 1971, s. 355-356.

${ }^{11}$ Lesia Ukrainka. Lysty 1876-1897..., s. 146. 
20 записано рукою М. Косача та 1 пісня в запису Лесі Українки ${ }^{12}$. Про фольклорні вподобання Михайла Косача свідчать не тільки численні записи баладних, історичних та ліричних любовних пісень, а й спроби систематизації та цифрового шифрування фольклорних текстів:

Розігнався я оце мотиви пісень на цифри перекладати та закон знаходити, та поки що нічого не виходить, загайне діло це перекладання, тим то поки одну й переклав, як перекладу більше, то, може, що й удасться закметити (Лист М. Косача від 4 авг[уста] 1890 р. з Колодяжного до Косач О. П. (матері) $)^{13}$.

Зокрема йдеться про спосіб подачі варіантів, коли рядки двох пісенних текстів нумеруються відповідно арабськими та римськими цифрами, між однаковими частинами тексту ставиться знак «=», а відмінні фрагменти тексту наводяться повністю.

Частина пісень баладного жанру в записах Михайла Косача згрупована тематично: «Баллада про завоз дівчини» (4 записи, 3 них 3 - варіанти пісні «Ой у полі, полі коршомка стояла»), «Чари» (4 тексти, два з яких - варіанти пісні «Ой чиє ж то поле, широкі загони?») та «Різни баллади» (9 сюжетів). Очевидно, Леся Українка мала намір їх опублікувати, про що йдеться в листі до М. Драгоманова від 5 квітня 1894 р.:

Ви не довольні, що я послала до Ж[итя] і С[лова] такий нецікавий матеріял, але Фр[анко] просив у мене власне сього. Не знаю, чи буде цікаво, як я пошлю туди пісні баладного змісту (теж сирий матеріал, бо довести до пуття я не вмію)? Міша певне міг би написати й краще, але він тепер дуже зайнятий, вчиться до екзаменів, а разом з тим він лаборантом при фізичному кабінеті, так що часу як відмірено (Лист Лесі Українки від 5(17).IV.1894 р. з Києва до Драгоманова М. П.) ${ }^{14}$.

${ }_{12}$ Muzei vydatnykh diiachiv ukrainskoi kultury v Kyievi, od. zb. D-2223.

${ }^{13}$ M. Kosach (Mykhailo Obachnyi), Tvory. Pereklady. Lysty. Zapysy kobzarskykh dum, uporiad. ta koment. L. Miroshnychenko, nauk. red. M. Sulyma, Komora, Kyiv 2017, s. 275-276.

${ }^{14}$ Lesia Ukrainka. Lysty 1876-1897..., s. 279. 
Тексти трьох баладних пісень («Чорна хмаройка наступає», «Була вдовойка в конець села» та «Шла Мар'юся в поле»), що виконувалися під час купальського свята, увійшли до праці «Купала на Волині» Лесі Українки, опублікованої у львівському журналі «Житє і Слово» ${ }^{15}$. Письменниця записала їх у селах Колодяжному (№o 12, 13) та Біліні (№ 18) Ковельського повіту влітку 1890 р. в часі «живого дійства»16.

Баладні пісні краю записувала також Олена Пчілка. Одну 3 них - старовинну баладу про дівчину-воячку - вона опублікувала в розвідці «Украинские колядки (текст волынский)», що побачила світ у журналі «Киевская старина» за 1903 рік ${ }^{17}$.

Косачам удалося зафіксувати тексти понад 30 баладних пісень, що репрезентують народнобаладний репертуар з теренів українсько-польського пограниччя кінця XIX ст. та дають цінний матеріал для порівняльних студій, виявлення спільного і відмінного у культурних надбаннях сусідніх народів.

Серед балад, записаних Косачами, є пісні з міжнародного баладного фонду (про мандрівку зведеної дівчини, на теми інцесту, про отруєння матір'ю невістки і сина, про вбивство дружиною чоловіка), а також ті, що постали на основі українських суспільних і побутових реалій. 3 цього погляду слушною видається думка О. Дея, який стверджував: «Сюжети всіх українських балад, у тому числі перейнятих від сусідів, були породжені або «відшліфовані» (якщо йдеться про запозичені) побутовими та історичними обставинами національного життя» 18 .

3-поміж баладних пісень про особисті дошлюбні відносини вирізняються сюжети на теми суперництва в коханні, отруєння чарами, втрати дівочого вінка, зведення підмовленої дівчини та ін.

${ }^{15}$ Lesia Ukrainka. Kupala na Volyni, «Zhytie i Slovo», t. 1, kn. 2, 1894, s. 276-284. ${ }^{16}$ V. Pokalchuk, Slidamy Lesi Ukrainky: znaiomstvo z Klymentiiem Kvitkoiu i Olhoiu Petrivnoiu Kosach; Batky Lesi Ukrainky [w:] Spohady pro Lesiu Ukrainku, Dnipro, Kyiv 1971, s. 114.

${ }^{17}$ Olena Pchylka, Ukrainski koliadky (tekst volynskyi)..., s. 152-175.

${ }_{18}$ Balady. Kokhannia ta doshliubni vzaiemyny..., s. 13. 
На українсько-польському пограниччі поширений сюжет балади про зведення дівчини, в якому, за словами I. Франка, «дівчина показується просто одуреною, ошуканою, або й насильно зганьбленою»19. Докладний огляд українських, білоруських і польських варіантів сюжету свого часу зробив М. Довнар-Запольський ${ }^{20}$, а Цезар Нейман опублікував коротеньку розвідку про цю баладу, де через польські і чеські варіанти приводить iï до зв’язку з бретонською легендою про Синю Бороду ${ }^{21}$.

Полісько-волинські балади про зведення дівчини в записах М. Косача неоднакові щодо розгортання сюжету: в одних зводитель топить свою жертву, в інших - спалює. Так, з містечка Миропілля Звягельського повіту походить пісня «Ой у полі, полі коршомка стояла», де козак кидає намовлену дівчину «у Дунай глибокий» ${ }^{22}$. Ще К. Квітка, який присвятив баладам цієї тематики окрему розвідку, зауважив:

Історія, що кінчиться топленням дівчини, характеристична найбільше для поляків (взагалі існують три версії: а) дівчина втонула, б) не втонула, в) кінець неясний). $<\ldots>$ Пісні такого змісту українською мовою існують у північно-західній частині України, але й там вони рідші, ніж пісні, що кінчаться спаленням дівчини» 23.

Численні польські паралелі тексту «о dziewczynie uwiedzonej», наведені у збірнику О. Кольберга «Покуття» ${ }^{24}$, підтверджують висновок ученого. Тут, як і в волинському варіанті, схожі ситу-

19 I. Franko, Zhinocha nevolia v ruskykh pisniakh narodnykh [w:] I. Franko, Zibrannia tvoriv, u 50 t., t. 26, Naukova dumka, Kyiv 1980, s. 220.

${ }^{20}$ Belorusskoe Polese. Sbornyk etnohrafycheskykh materyalov, sobrannykh M. Dovnar-Zapolskym, vyp. 1. Pesny pynchukov, Kyev 1895, nr 555 i dodatok III, nr 22.

${ }^{21}$ Materialy etnograficzne $z$ okolic Pliskowa w powiecie Lipowieckim. Zebrane przez pannę Z. D., opracowat Nejman Czesław [w:] Zbiór wiadomości do antropologii krajowej, t. 8, 1884.

${ }^{22}$ Muzei vydatnykh diiachiv ukrainskoi kultury v Kyievi, od. zb. D-2223, ark. 29-33.

${ }^{23} \mathrm{~K}$. Kvitka, Ukrainski pisni pro divchynu, shcho pomandruvala $z$ zvodytelem, «Povidomlennia Kabinetu muzychnoi etnohrafii», nr 2, Kyiv 1926, s. 4.

${ }^{24}$ O. Kolberg, Lud..., m. 30. Pokucie, cz. II, nr 22-23. 
ації, діалоги: дівчина добровільно погоджується на мандрівку, потім розкаюється, зводитель топить іiі у ставку (рідше - в Дунаї). Часто варіанти схожі навіть деталями. Так, у волинському тексті, записаному М. Косачем, говориться, що зводитель заїхав «з Україноньки», себто, з чужого, іншого краю, бо, як пояснює К. Квітка, «там, де співалися ті пісні, Україною звали сторону, що лежить на схід і південь» 25 . Подібне бачимо і в польських баладах: зводитель приїхав «z cudzej ukrainy», «z cudzej krainy», «z dalekiej ukrainy» ${ }^{26}$. Зазвичай польські балади називають конкретні імена персонажів («Kazinka z Jasienkiem», «Jasienko» i «Anusia», «Јаś» та «Marysia» і под.); в україномовних текстах ними виступають дівчина і козак. У класичному польському тексті та в полісько-волинських баладах момент насильства під час намови та втечі відсутній. Польські балади підкреслюють нещирість почуттів зводителя, якого цікавить не дівчина, a iii грошi: «nabierz złota dosyć / żeby miał co nosić» 27 .

Попри схожість українських і польських балад цього сюжетного типу, К. Квітка на підставі мелодичних розбіжностей відкидав їхню генетичну спорідненість:

Не вважаючи на поетичну близькість деяких українських і польських варіантів, я не знайшов між численними і розмаїтими польськими мелодіями до цієї пісні жодної, яку б можна було поставити в генетичний зв'язок з українською 28.

Ще один варіант балади в запису М. Косача з Миропілля пісня «Ой у полі, полі коршомка стояла», де йдеться про підмовлену дочку шинкаря Хайку та їі спалення. На думку К. Квітки, «Цей мотив чужий для західно-європейських та польських

${ }^{25}$ K. Kvitka, Ukrainski pisni pro divchynu, shcho pomandruvala $z$ zvodytelem..., s. 4.

${ }^{26}$ Pieśni ludu polskiego: serya I / zebrał i wydał Oskar Kolberg, s. 27-71, https:// polona.pl/item/piesni-ludu-polskiego-serya-i-zebral-i-wydal-oskar-kolberg,MT A5MjczODA/8/\#info:metadata [20.11.2020].

27 Ibid., s. 35 [20.11.2020].

${ }^{28}$ K. Kvitka, Ukrainski pisni pro divchynu, shcho pomandruvala z zvodytelem..., s. 6. 
пісень на тему мандрування з зводителем; на Україні пісні з цим родом катастрофи становлять тип дуже люблений» ${ }^{29}$. Це спостереження знайшло підтвердження в найбільшому сучасному виданні українських баладних пісень ${ }^{30}$. Польських варіантів з таким розгортанням дії не виявлено. Однак польські балади пропонують дуже різноманітні варіанти вирішення конфлікту: зводителя, що занапастив дівчину, вбиває погоня (брати скривдженої) ${ }^{31}$; дівчина сама чинить розправу ${ }^{32}$.

Не менш цікавий варіант балади про зведення дівчини - в запису М. Косача з містечка Мельниця Ковельського повіту, в якому підмовленою героїнею, як і в попередньому, виступає Хайка, проте намовляють ії не козаки, а «салдати», що перебувають у корчмі на постої (у польських баладах у ролі звідника часом виступає «mazur»). Така національна атрибуція зводителів може бути ознакою більш пізнього походження балади. Ïї розв'язка схожа на ту, що притаманна баладам польського походження: солдати топлять Хайку в Дунаї. За зовні окресленою побутовою ситуацією та життєвими трагічними колізіями молодої дівчини незримо проглядають конфліктні моменти на рівні свій / чужий, інородець. Специфічного національного колориту цій баладі надають рефрени «Ох вей, мамуню, зуд, зуд, ну-ну-ну, / коршомка стояла, та-рі-рі-бом-бом», а також прикінцева заувага записувача: «Далі йде жидівська ламентація прозою, напр. Ой чи не мала ти хати, чи не було в тебе тата?.. і т. і.»33.

Серед баладних пісень, записаних Косачами, переважають сюжети про родинні взаємини і конфлікти, спричинені одруженням без любові, тривалою розлукою (тема інцесту), втручанням матері у стосунки подружжя, що веде до вбивства, отруєння та інших трагічних розв'язок.

${ }^{29}$ Ibid., s. 11.

${ }^{30}$ Balady. Kokhannia ta doshliubni vzaiemyny..., s. 262-318.

${ }^{31}$ O. Kolberg, Pieśni z Podola rosyjskiego w latach 1858 i 1862 [w:] Zbiór wiadomości do antropologii krajowej, t. 12, 1888, nr 12.

${ }^{32}$ O. Kolberg, Lud..., m. 38. Chetmskie, cz. II, s. 9-10, nr 9.

${ }^{33}$ Muzei vydatnykh diiachiv ukrainskoi kultury v Kyievi, od. zb. D-2223, ark. 29-33. 
Лесі Українці належить один із записів народної балади про сватання сина до матері і брата до сестри («Ой 3-под того явора» $)^{34}$. Пісня надзвичайно розповсюджена в Україні, де вона відома як купальська, веснянка, але найчастіше ії виконання не обмежувалося певним часом ${ }^{35}$. Польські паралелі з нотами опубліковані в ряді збірників XIX ст. ${ }^{36}$.

Про увагу Косачів до цієї баладної пісні свідчить один із листів М. Косача до Лесі Українки: «Дядько питається пісні про оженіння матері з сином, але такої я ніде і тіні не чув, крім “корабля" і “вдову”, треба цюю хіба йому послати» (Лист М. Косача від 18.VIII.[18]91 р. з Колодяжного до Косач Л. П.). ${ }^{37}$ А вже за місяць з Дерпта він уточнює в рідних:

Чи послала йому [М. Драгоманову. - Л. С., Т. Д-Т.] Леся пісню про «удову та синів»? Як ні, то хай спитається у Кароля варіант цеї пісні: він тим цікавий, що, здається мені, перейнятим з літературного білоруського переказу, так принаймні, на мою думку, показує мова цего варіанту (Лист М. Косача від 18.IX.1891 з Dorpat до О. П. Косач (матері) ${ }^{38}$.

Текст у запису Лесі Українки має традиційну фабулу: народивши двох синів, удова пускає їх на Дунай і просить сили природи оберігати і годувати дітей; після довгої розлуки вона не впізнає дорослих синів, котрі сватають матір і сестру, а потім

${ }^{34}$ Kolodiazhenski pisni z rukopysnoho zoshyta $v$ zapysakh Lesi Ukrainky ta Olhy Kosach, faksymilne vydannia rukopysu ta vidtvorennia tekstu, Volyn. obl. druk., Lutsk 2006, s. 61.

${ }^{35}$ L. Semeniuk, Ukrainski narodni balady Zakhidnoho Polissia (zahalnoukrainskyi kontekst i rehionalna svoieridnist), RVV «Vezha» VNU im. Lesi Ukrainky, Lutsk 2009, s. 51.

${ }^{36}$ O. Kolberg, Lud..., m. 30. Pokucie, cz. II, nr 35-37; O. Kolberg, Lud..., m. 36. Wolyń, nr 537; Materiały etnograficzne $z$ okolic Pliskowa w powiecie Lipowieckim..., t. 8, nr 128; B. Popowski, Pieśni ludu ruskiego ze wsi Zalewańszczyzny (Winnickiego pow.) [w:] Zbiór wiadomości do antropologii krajowej, t. 8, 1884, nr 10, 21.

${ }^{37}$ M. Kosach (Mykhailo Obachnyi), Tvory. Pereklady. Lysty. Zapysy kobzarskykh dum, Komora, Kyiv 2017, s. 289.

${ }^{38}$ Ibid., s. 298. 
самі зізнаються, хто вони насправді і кепкують з удови; це запобігає інцесту. Сюжетне уповільнення дії в баладі досягається завдяки трикратним зверненням удови до сил природи (моря, риби, жовтого піску), дублюванню питань та відповідей героїв. М. Драгоманов, наполягаючи на можливому іï зв'язку із солдатськими піснями ${ }^{39}$, міг спиратися на схожі варіанти із привнесеною московською лексикою: «Ой син матки не берьоть, / Матка за сина не йдьоть, / Ой брат сестри не берьоть, / Сестра за брата не йдьоть!» ${ }^{40}$.

Один із найбільш оригінальних баладних текстів у запису Лесі Українки - пісня-балада на тему інцесту «Ой у полю корчомка» ${ }^{41}$, широко відома в українському, білоруському та польському ${ }^{42}$ фольклорі. Традиційно вона входила в комплекс весняного та купальського календарного циклів і відображала ритуальні моменти поведінки в ці проміжки часу ${ }^{43}$. Сюжет пісні розгортається у специфічно українських обставинах, місцем події названо корчму. Звичною $є$ й соціальна атрибуція персонажів шинкарка, наймичка, козак або чумак, на якому «жупан дран», та найменування брата і сестри («Карпів син» і «Карп'янка»). Інші етнічні характеристики персонажів - у подібних польських баладах («W dole kalinka stojała»): «z Krakowa jestem wójtówna», «z Krakowa jestem wójtowic» ${ }^{4}$. Поліська балада в запису Лесі Українки підкреслює моральне недопущення кровозмішання: брата із сестрою, що мимовільно згрішили, не приймають у монастир, від них відвертається ліс зі звіриною та море з рибою; спокуту вони несуть через метаморфозу в квітку братики.

${ }^{39}$ Narodni melodii. Z holosu Lesi Ukrainky zapysav i uporiadyv Klyment Kvitka..., s. $105-111$.

${ }^{40}$ Kolodiazhenski pisni z rukopysnoho zoshyta $v$ zapysakh Lesi Ukrainky ta Olhy Kosach..., s. 61.

${ }^{41}$ Ibid., s. 62.

${ }^{42}$ O. Kolberg, Lud..., m. 30. Pokucie, cz. II, nr 32-33.

${ }^{43} \mathrm{M}$. Hrymych, $Z$ istorii dvokh ukrainskykh balad pro intsest, "Narodna tvorchist ta etnohrafiia», nr 3, 1990, s. 44-45.

${ }^{44}$ Pieśni ludu polskiego: serya I / zebrat i wydał Oskar Kolberg, s. 218 [20.11.2020]. 
Схожий сюжет із с. Перековичі Ковельського повіту («Була вдова на Подолі» з циклу «Різни баллади») в запису М. Косача може відображати більш пізній період функціонування пісні: до інцесту тут не доходить, сестра і брати впізнають один одного, проте їхні життєві шляхи розходяться: «Старші пішли (2) панувати, / А найменший (2) горувати, (2) / Хліба й солі (2) заробляти, (2) / Стару матір годувати» 45 . Інший сюжетний хід бачимо в польських баладах: брат відпускає впізнану сестру та наказує «nie rób darmo nikomu» або пропонує вчинити самогубство ${ }^{46}$.

Аналізуючи польські варіанти балади про шлюб брата 3 невпізнаною сестрою, Я. Бистронь стверджує, що вона найбільше відома в північній Польщі, звідки перейшла на польсько-білоруське пограниччя. Джерела польської пісні він знаходить у німецькому фольклорі, де ця тема була надзвичайно поширена ${ }^{47}$.

Балада про трагедію слуги, якого покохала пані, широко відома не лише в Україні, а й у білорусів, поляків та інших слов’янських народів. Варіант у запису Лесі Українки («Молодая пані Петруся кохала») має помітку «Луцьке, від Лариси Косач» ${ }^{48}$. Текст збережений не повністю, втрачено 13-16 рядки. До першого рядка пісні Леся Українка подала таку авторську примітку: «Співають теж: Вельможная пані... або Пані пана мала, Петруся кохала». Пісня розгортає сюжет у такій послідовності: залицяння пані до слуги, зрада чоловікові за його відсутності, діалог пані зі слугами, покарання Петруся, побивання пані за коханцем. Пісні притаманний соціально загострений конфлікт, що зумовлений становою нерівністю персонажів. Остання стає причиною трагічного фіналу та викликає сумніви в щирості почуттів пані до слуги, що став жертвою iї примхи.

${ }^{45}$ Muzei vydatnykh diiachiv ukrainskoi kultury v Kyievi, od. zb. D-2223, ark. 29-33.

46 Pieśni ludu polskiego: serya I / zebrał i wydał Oskar Kolberg, s. 217-223 [20.11.2020].

47 J. Bistron, Piesn o spotkaniu si rodyenstwa [w:] Lud, t. 32, 1934, s. 45.

${ }^{48}$ Muzei vydatnykh diiachiv ukrainskoi kultury v Kyievi, od. zb. D-2223, ark. 4. 
Пісня-балада про пані і Петруся в запису М. Косача з села Старі Кошари Ковельського повіту («Чи чули ви, люде, такої новини») має більш розгорнутий сюжет, порівняно із записом Лесі Українки. Усі структурні компоненти тексту логічно вмотивовані обставинами розгортання драми. У варіанті подано локальну прив’язку події («Чи чули ви, люде, такої новини, / Забито Петруся в Джуранській долині»). Драматизм ситуації поглиблюється спробою Петруся покаятися перед паном та неможливістю виправдати вчинене: «Не буду я тебе в кайдани кувати, / Гей, не буду тобі життя дарувати» ${ }^{49}$.

Паралельні польські тексти з іншими мелодіями та без нот увійшли до збірників О. Кольберга ${ }^{50}$ і 3. Рокосовської1, Вацлава 3 Олеська ${ }^{52}$. У польській баладі «Wyjechał pan z chartami na pole», на відміну від української, обранець пані - не селянин, a «krawczyk», що послаблює поляризацію героїв та соціальну гостроту конфлікту; соціальний стан пана теж уточнено (переважно він «starosta»), як і ім’я головної героїні («Каsia») ${ }^{53}$.

Близькі польські паралелі, записані О. Кольбергом на Поділлі та Холмщині ${ }^{54}$, має балада про вбивство чоловіком жінки за намовою матері, відома в запису М. Косача з Миропілля Звягельського повіту («Мати сина на лвалт оженила»). Різномовні тексти пояснюють причину намови сина до злочину тим, що свекруха невістки «не злюбила», «ne do lubowi newistoczku wziała» 55 . Мати дає синові докладну пораду, як скарати дружину: «Піди,

49 Ibid, ark. 29-33.

50 O. Kolberg, Lud..., m. 36. Wołyń, nr 536; O. Kolberg, Lud..., m. 30. Pokucie, cz. II, nr 56, 57; O. Kolberg, Lud..., m. 38. Chełmskie, cz. II, nr 1.

51 Z. Rokossowska, Wesele i pieśni ludu ruskiego ze wsi Jurkowszczyzny w powiecie Zwiahelskim na Wołyniu [w:] Zbiór wiadomości do antropologii krajowej, t. VII, 1883, s. 171.

52 Pieśni polskie i ruskie ludu Galicyjskiego / zebrał i wydał Waclaw z łeska, Lwów 1833, s. 514, nr 32.

53 Pieśni ludu polskiego: serya I / zebrał i wydał Oskar Kolberg, s. 84-115 [20.11.2020].

54 O. Kolberg, Pieśni z Podola rosyjskiego w latach 1858 i 1862..., nr 12; O. Kolberg. Lud..., m. 38. Chetmskie, cz. II, nr 8.

55 O. Kolberg, Lud..., m. 30. Pokucie, cz. II, nr 180. 
сину, на ярмарок пішки, / Купи, сину, дротяниї віжки. (2) / Зв'яжи милій і руки, і ніжки. / Купи, сину, дротянку-нагайку, / Та бий жінку з вечора до ранку» ${ }^{56}$. Про такі ж засоби тортур («wołosiani wiżky», «nahajku drotianku») йдеться і в польських баладах ${ }^{57}$. В українській версії сюжету син, усвідомивши скоєне, висловлює протест владній матері і відмовляється ховати сліди злочину. Польська балада завершується намовами матері приховати скоєне та констатацією наслідків драми: «Tak kozak czerez maty stareńku / poteriaw swoju mołodu myłeńku» ${ }^{58}$.

У фольклорному репертуарі поляків та українців на Волині та в Східній Польщі зберігся драматичний сюжет про вбивство жінкою свого чоловіка. Польський дослідник Е. Кухарський вважав цю баладу шедевром середньовічної шляхетської поезії59. У полісько-волинському пісенному репертуарі вона менш поширена. В запису М. Косача з Миропілля на Звягельщині («Ой зима, зима та й холодная») жінка, вчинивши злочин, не приховує його: «А жона мужа та й зарізала, / В зеленим саду та й повісила. / А сама ходить, рученьки ломить: / - Ой горе, горе 3 таким мужем жить, / А іще горійше, як мужа забить» ${ }^{60}$. У класичному польському тексті балади «Stała nam się nowina» після повідомлення про те, що «pani pana zabiła», докладно описано, як пані спершу ховає сліди злочину («W ogródku schowała, / rutkę na nim nasiała»), а далі виправдовується перед братами зниклого чоловіка. Не повіривши іiі аргументам, брати не менш жорстоко карають злочинницю: «Wyjechali za lasy / I tam darli z niej pasy» ${ }^{61}$.

За спостереженням Л. Вахніної, поширення цього сюжету

${ }^{56}$ Muzei vydatnykh diiachiv ukrainskoi kultury v Kyievi, od. zb. D-2223, ark. 29-33. ${ }^{57}$ O. Kolberg, Lud..., m. 30. Pokucie, cz. II, nr 180.

58 Ibid.

59 E. Kucharski, «Pani Pana zabiła» jako zabytek średniowiecznej poezji dworskiej, «Pamiętnik Literacki», cz. 28, 1931, s. 349-537.

${ }^{60}$ Muzei vydatnykh diiachiv ukrainskoi kultury v Kyievi, od. zb. D-2223, ark. 29-33.

${ }^{61}$ Pieśni ludu polskiego: serya I / zebrał i wydał Oskar Kolberg, s. 13-26, [20.11.2020]. 
у фольклорному репертуарі українців «відображає і певні національні риси українських жінок, для яких протягом століть були характерні такі риси, як гордість, впевненість у собі, домінування в родинному оточені та право приймати рішення, які стосувалися навіть людського життя чи то власного чоловіка, чи коханця» ${ }^{62}$. Ці спостереження стосуються й польського етнічного середовища.

Наведений матеріал переконує в тому, що народна балада як один із найбільш поширених фольклорних жанрів у пісенному репертуарі Волині й Західного Полісся, перебувала в полі фольклористичних зацікавлень Лесі Українки та членів ії родини. Тим самим вони прислужилися справі фіксації народнопісенної традиції полісько-волинського краю. Зібраний Косачами в кінці XIX ст. матеріал (зокрема, понад три десятки баладних сюжетів різноманітної тематики) засвідчує тематичну різноманітність, виразний національний колорит, близьку спорідненість із польськими баладами пограниччя. Особливу схожість демонструють балади, що належать до міжнародного баладного фонду (про мандрівку зведеної дівчини, на теми інцесту, про отруєння матір'ю невістки і сина, про смерть слуги через примху пані, про вбивство дружиною чоловіка). Українські і польські варіанти пісень подібні структурними компонентами текстів, життєвими трагічними колізіями, побутовими ситуаціями, діалогами персонажів, художніми деталями. Попри спорідненість сюжетів, образів, художньо-виражальних засобів, різномовні тексти пропонують різні, часто кардинально відмінні шляхи вирішення особистих і родинних конфліктів. Окрім того, вони позначені національним колоритом, відображають особливості місцевого побуту, реалії суспільного життя українців, поляків та інших етносів (наприклад, євреїв). Помітною є національна атрибуція персонажів, їх питомо національні найменування (особливо в польських текстах), поляризація за принципом свій / чужий,

${ }^{62}$ L. Vakhnina, Ukrainsko-polski paraleli u baladi «Oi stalasia novyna» [w:] Kyivski polonistychni studii, t. 19, Kyiv 2012, s. 477-481. 
інородець. Українські та польські сюжети увиразнюють ментальні етнічні стереотипи носіїв фольклору, зокрема в поглядах на роль жінки в родині та суспільстві. У перспективі цей аспект може бути предметом окремого наукового дослідження.

\section{References}

Balady. Kokhannia ta doshliubni vzaiemyny, uporiad. O. Dei, A. Yasenchuk (teksty), A. Ivanytskyi (melodii), vstup. st. O. Deia, Nauk. dumka, Kyiv 1987.

Balady. Rodynno-pobutovi stosunky, uporiad. O. Dei, A. Yasenchuk (teksty), A. Ivanytskyi (melodii), vstup. st. O. Deia, Nauk. dumka, Kyiv 1988.

Belorusskoe Polese. Sbornyk etnohrafycheskykh materyalov, sobrannykh M. Dovnar-Zapolskym, vyp. 1. Pesny pynchukov, Kyev 1895.

Bistron J., Piesn o spotkaniu si rodyenstwa [w:] Lud, t. 32, 1934, s. 45-67.

Franko I., Zhinocha nevolia v ruskykh pisniakh narodnykh [w:] Franko I. Zibrannia tvoriv, u 50 t., t. 26, Naukova dumka, Kyiv 1980, s. 210-253.

Hrymych M., $Z$ istorii dvokh ukrainskykh balad pro intsest, «Narodna tvorchist ta etnohrafiia, nr 3, 1990, s. 38-45.

Kolberg O., Pieśni z Podola rosyjskiego w latach 1858 i 1862 [w:] Zbiór wiadomości do antropologii krajowej, t. 12, 1888, $\mathrm{nr} 12$.

Kolberg O., Lud. Jego zwyczaje, sposób życia, mowa..., m. 36. Wołyń, Kraków 1857-1890.

Kolberg O., Lud. Jego zwyczaje, sposób życia, mowa..., m. 30. Pokucie, cz. II, Kraków 1857-1890.

Kolberg O., Lud. Jego zwyczaje, sposób życia, mowa..., m. 38. Chetmskie, cz. II, Kraków 1857-1890.

Kolodiazhenski pisni $z$ rukopysnoho zoshyta $v$ zapysakh Lesi Ukrainky ta Olhy Kosach, faksymilne vydannia rukopysu ta vidtvorennia tekstu, Volyn. obl. druk., Lutsk 2006.

Kosach M. (Mykhailo Obachnyi), Tvory. Pereklady. Lysty. Zapysy kobzarskykh dum, uporiad. ta koment. L. Miroshnychenko, nauk. red. M. Sulyma, Komora, Kyiv 2017.

Kosach-Kryvyniuk O., Oznaiomlennia Lesi Ukrainky z narodnoiu tvorchistiu [w:] Skrypka T. Spohady pro Lesiu Ukrainku, u 2-kh t., t. 1, Tempora, Kyiv 2017.

Kraszewski J., Wspomnienia Wołynia, Polesia i Litwy, t. 1, Wilno 1840.

Kucharski E., «Pani Pana zabiła» jako zabytek średniowiecznej poezji dworskiej, «Pamiętnik Literacki», cz. 28, 1931, s. 349-537. 
Kvitka K., Ukrainski pisni pro divchynu, shcho pomandruvala z zvodytelem, «Povidomlennia Kabinetu muzychnoi etnohrafii», nr 2, Kyiv 1926, s. 4-31.

Lesia Ukrainka: dokumenty i materialy: 1871-1970, vidp. red. S. Pilkevych, Naukova dumka, Kyiv 1971.

Lesia Ukrainka, Kupala na Volyni, «Zhytie i Slovo», t. 1, kn. 2, 1894, s. 276284.

Lesia Ukrainka, Lysty 1876-1897, uporiadkuvannia V. Prokip (Savchuk), peredmova V. Aheievoi, Komora, Kyiv 2016.

Materiały etnograficzne $z$ okolic Pliskowa w powiecie Lipowieckim. Zebrane przez pannę Z. D., opracował Nejman Czesław [w:] Zbiór wiadomości do antropologii krajowej, t. 8, 1884.

Muzei vydatnykh diiachiv ukrainskoi kultury v Kyievi, od. zb. D-2223.

Muzychnyi folklor z Polissia u zapysakh F. Kolessy ta K. Moshynskoho, uporiadkuv. ta komentari S. Hrytsy, Kyiv 1996.

Narodni melodii. Z holosu Lesi Ukrainky zapysav i uporiadyv Klyment Kvitka, ch. I-II, Kyiv 1917-1918.

Olena Pchylka, Ukraynkye koliadky (tekst volynskyi), «Kyevskaia staryna», t. 80, nr 1, 1903, s. 152-175.

Pauli Ż., Pieśni ludu ruskiego w Galicji, t. 1-2, Lwów 1838.

Pieśni ludu polskiego: serya I / zebrat i wydał Oskar Kolberg, https://polona.pl/ item/piesni-ludu-polskiego-serya-i-zebral-i-wydal-oskar-kolberg,MTA5Mjc zODA/8/\#info:metadata

Pieśni ludu, zebrat w latach 1861-1891 Zygmunt Gloger. Muzykę opracował Zygmunt Noskowski, Kraków 1892.

Pieśni polskie i ruskie ludu Galicyjskiego zebrat i wydał Waclaw z łeska, Lwów 1833. Pokalchuk V., Slidamy Lesi Ukrainky: znaiomstvo z Klymentiiem Kvitkoiu i Olhoiu Petrivnoiu Kosach; Batky Lesi Ukrainky [w:] Spohady pro Lesiu Ukrainku, Dnipro, Kyiv 1971, s. 104-109.

Popowski B., Pieśni ludu ruskiego ze wsi Zalewańszczyzny (Winnickiego pow.) [w:] Zbiór wiadomości do antropologii krajowej, t. 8, 1884.

Rokossowska Z., Wesele i pieśni ludu ruskiego ze wsi Jurkowszczyzny w powiecie Zwiahelskim na Wolyniu [w:] Zbiór wiadomości do antropologii krajowej, t. VII, 1883.

Semeniuk L., Ukrainski narodni balady Zakhidnoho Polissia (zahalnoukrainskyi kontekst i rehionalna svoieridnist), RVV «Vezha» VNU im. Lesi Ukrainky, Lutsk 2009.

Stecki T., Wołyń pod względem statystycznym, historycznym i archeologicznym, т. 1, Lwów 1864.

Vakhnina L., Folklor ukraynsko-polskoho pohranychia [w:] Hranytsy, kultury y ydentychnosty. Etnolohyia vostochnoslavianskoho pohranychia, Moskva 2012, s. 254-261. 
Vakhnina L., Ukrainsko-polski paraleli u baladi «Oi stalasia novyna» [w:] Kyivski polonistychni studii, t. 19, Kyiv 2012, s. 477-481.

Wachnina L., Folklor ukraińsko-polskiego pogranicza (na przykładzie ballady) [w:] Polska-Ukraina. Pogranicze kulturowe i etniczne, Wrocław 2008, s. 227240.

Z lystuvannia Filareta Kolessy, «Narodna tvorchist ta etnohrafiia», nr 4, 1971, s. 54-57. 
II. W kręgu ego-dokumentów ukraińskich i polskich 


\section{Tetiana Bovsunivska}

Taras Shevchenko Kyiv National University (Ukraine)

ORCID: 0000-0002-2018-4674

\section{Діарист як творець документальної медіації}

\section{Diarist as a creator of documentary mediation}

\section{Abstract:}

The paper is devoted to the study of mediation and mediators in ego-documentary prose. The are nine possibilities of mediation formation in the diary (Taras Shevchenko's "Diary" is taken as a sample): 1) by means of memories, 2) as dictated by heart, 3) by means of emotional temporitum, 4) through the actualization of personalities, 5) as an imitation of the previous genre form, 6) as revision of the past, 7) in dreams, 8) by means of language expression, 9) by using the Bible. Shevchenko's journal is characterized by the movement of everyday life to the realm of the transcendent. If in the literature of Romanticism the mediators are usually located in the transcendent, then in Shevchenko to this classical landmark of the Romantics is added everyday life as dreamed and transcendent.

Keywords: non-fiction, self-documentary prose, diary, Taras Shevchenko, diarist, transcendent, mediator, mediation.

Проблема автодокументальної прози не в тому, що вона межує 3 чистою художньою вигадкою, а в тому, що ця вигадка утримується в межах документалізму, є його послідовним наслідуванням, так би мовити, пересотворенням в межах умовно визнаної достовірності. Звідси значні утруднення в ідентифікації жанрів нон-фікшн. Адже підсвідомо дослідники сприймають текст будь-якого жанру нон-фікшн як документальний, майже повністю не беручи до уваги саму можливість чистої вигадки в такому творі. 3 цього приводу Олена Местергазі писала: «Немає сумніву у тому, що істинний твір мистецтва - створений він за 
допомогою вимислу або принципово іншим способом, який відкидає вимисел та спирається на голос самого діючого факта наділений всіма ознаками художності. I в цьому сенсі поділ на літературу fiction i non-fiction - всього лише умовність...» ${ }^{1}$. Одним із аспектів, які сприяють деякому розмиванню межі між fiction i non-fiction, i є медіація, яка в щоденникових записах так само присутня, як і в художніх текстах.

До того ж медіативні аспекти автодокументальної прози становлять іï стійку характеристику. Медіація та медіатор у літературі - це прагнення письменника віднайти омріяний ідеал та прокласти до нього дорогу всупереч усім спротивам. Рене Жирар пише: “Учень спрямовується до того, на що йому вказує - або нібито вказує, - зразок лицарської поведінки. Назвемо такий зразок медіатором бажання" 2 . І за цим визначенням медіація це процес проявлення бажання, прагнення, воління до чогось. Рене Жирар твердить, що “медіація породжує друге бажання, зовсім подібне до того, яке відчуває медіатор, - а це означає, що ми завжди маємо справу з двома конкуруючими між собою бажаннями"' Медіатор - втілення жаданої ідеї або зразка і може бути як суб'єктом, так і об’єктом. Медіація - шлях до нього

Звичайно, документальна медіація - явище складне, оскільки засноване на історичних фактах та свідченнях, які можна перевірити. Діарист при цьому намагається приховати медіативне підгрунтя оповіді. Оця-то прихована медіація в автодокументальному, переважно щоденниковому, тексті і становить нашу наукову зацікавленість.

${ }^{1}$ E. H. Mesterhazy, Lyteratura non-fykshn/non-fiction. Eksperymentalnaia entsyklopedyia, izd. Sovpadenye, Moskva 2007, s. 73.

$2 \mathrm{R}$. Zhyrar, Lozh romantyzma y pravda romana, per. s frants. A. Zyhmonta, Novoe lyteraturnoe obozrenye, Moskva 2019, s. 32.

${ }^{3} \mathrm{R}$. Zhyrar, Lozh romantyzma y pravda romana, per. s frants. A. Zyhmonta, Novoe lyteraturnoe obozrenye, Moskva 2019, s. 37.

${ }^{4}$ Див. про це докладно: Т. V. Bovsunivska, Poet yak transtsendentnyi mediator $v$ literaturi romantyzmu [w:] Literaturoznavchyi dyskurs vid baroko do postmodernu: Kolektyvna monohrafiia, up. i nauk. red. N. Levchenko, Maidan, LiublinKharkiv 2020, s. 365-379. 
Відносно самого терміна «діарист» треба відзначити, що він не має однойстайного поширення і часто підміняється такими термінами, як «автобіографіст», «белетрист», «хронографіст», «літописець», «хронікер», «біографіст», «бібліографіст», «хронолог», а до цього додайте класичні поняття «наратор», «оповідач», «автор», «упорядник» тощо. Зазвичай діаристом називають автора щоденника. Проблема медіації у щоденнику ніколи не розглядалася, оскільки цей жанр традиційно відносять до різновиду документалістики. Тому візьмемо за приклад «Журнал» Тараса Шевченка та розглянемо в ньому прийоми, за допомогою яких, власне, й формується медіація та медіатори:

1. Медіація формується через конструювання залучених до тексту спогадів. Фактично, більшість автодокументальних текстів пишуться за спогадами, але нас більше цікавить не сам спогад, а форма його презентації, ідеологічні наголоси та екстраполяції. «Одно воспоминание о прошедшем и виденном в продолжении этого времени приводит меня в трепет» ${ }^{5}$. «Дневник» Т.Шевченка містить велику кількість спогадів. Призначення кожного та дотичніть до медіатора - то тема окремого и досить великого дослідження. Зараз лише зауважу, що медіативна змістовність кожного спогаду - це факт, який легко встановлюється.

2. Медіація формується як продиктована серцем: «Обратимся к светлому и тихому, как наш украинский осенний вечер, и запишем все виденное и слышанное и все, что сердце продиктует» ${ }^{6}$. Серце - наскрізна категорія романтичної естетики та практики письма. Дослухатися власного серця в літературі українського романтизму (як і західного) й означало істинну достовірність. Сердечне вчування гарантувало дотримання істини за романтичним світоспогляданням.

3. Медіація формується як мета перегляду минулого під певним кутом зору. Нариклад, «для памяти минувших дней»7.

\footnotetext{
5 T. Shevchenko, Dnevnyk, Hoslytyzdat, Moskva 1954, s. 31.

${ }^{6}$ Ibidem, s. 31 .

7 Ibidem, s. 31.
} 
4. Медіація формується через емоційний темпоритм. Наприклад, у щоденнику Т.Шевченка уповільнений ідилічний темпоритм оповіді завжди пов'язується з вивільненням від муштри та казарми. У ньому криється ідеалізація звичайного життя, бо воно для автора і стає мрією. Домінанту емоційного темпоритму щоденника Т. Шевченка становить тяглість, очікування (свободи), що створюється за допомогою ретардаційного зображення. Свобода як медіатор присутня у всьому тексті. Очікування свободу, а потім насолода нею - одна із провідних медіативних ліній тексту. Казарменне життя також подається як небажана тяглість (беззмістовна повторюваність дій і актів, промов, покарань тощо).

5. Медіація формується через поперсональну актуалізацію 3 акцентом на певних вчинках. У записі від 13 червня згадується Яків Кухаренко, який написав Шевченкові листа вже після того, як дізнався про заборону листування з покараним поетом: «И - благороднейший друг! - написал мне самое искреннее? Самое задушевное письмо» ${ }^{8}$. Особливе місце у цьому посідає формування образу України: «Передо мной красовалася моя прекрасная, моя бедная Украина, во всей непорочной меланхолической красоте своей» ${ }^{9}$. Ідеалізація України у поета послідовно простежується у всьому щоденнику, утворюючи образ України омріяної, тобто один із провідних медіаторів тексту.

6. Медіація формується через наслідувальну жанрову форму журналу. Т. Шевченко удавано шкодує, що обрав цей жанр та мусить щодня робити якісь записи від 14 червня 1857 року:

Если правду сказать, я не вижу большой надобности в этой пунктуальной аккуратности. А так - от нечего делать. На бездельи и это рукоделье. Записному литератору или какому-нибудь поставщику фельетона? тому необходима эта бездушная аккуратность как упражнение, как его насущный хлеб ${ }^{10}$.

\footnotetext{
8 Ibidem, s. 33.

9 Ibidem, s. 65.

10 Ibidem, s. 34.
} 
7. На наступний день поет зазначає: «Что же я сегодня внесу в свой журнал? Совершенно нечего занести» ${ }^{11}[5$, с.35]. «Кончится ли, наконец, это гнусное существование, это однообразное записывание однообразнейших бесконечных дней» ${ }^{12}$. Таки наголошуване дотримання жанру, а саме - необхідність щоденних записів, поступово стає своєрідною грою для Т. Шевченка. Він одягає маску обивателя, звичайного дрібного мешканця імперії та ховається за нею у хвилини подолання тиску суєтного й одноманітного казарменного життя. Він ще не знає, що вже ніколи не буде мати цього родинного затишку, домівки, марудної щоденщини. Медіація посилюється очікуванням: «Несносный ветер, мучительная неизвестность!» ${ }^{13}$. Виконуючи вимоги жанру «журнала» робити щоденні записи, діарист Шевченко так і діє, щоразу констатуючи стан гнітючого очікування свободи: «20-е июля - день, в который я предполагал проститься с моею тюрьмою, так написал Лазаревскому и Кухаренку. А ветер, олицетворенная судьба, распорядился иначе. Что делать? Посидим еще за морем да подождем погоды» ${ }^{4}$. Медіація у цьому разі стає надзвичайно виразною.

8. Медіація формується в снах діариста. Так, сни Т. Шевченка межують з мареннями про свободу та мандри по рідному краю. Сформовані мрії та бажання поета у снах становлять не просто підсвідомі прагнення, а сферу трансцендентного, де медитація стає природною. Цікаво, що і в снах також з'являється побут, домівка, повсякдення. Тобто на відміну від поетичної медіації Шевченка, щоденникова більш приземлена навіть у снах. Сни підсилюють уявлення про повсякдення як трансцендентну сферу.

9. Підсиленню емоційної перипетії у щоденнику Шевченка сприяють численні афоризми та фразеологізми: «Надеждою

\footnotetext{
11 Ibidem, s. 35.

12 Ibidem, s. 101.

13 Ibidem, s. 103.

14 Ibidem, s. 105.
} 
живут ничтожные умы» ${ }^{15}$ (з Гете); «Свежо предание, а верится с трудом» ${ }^{16}$ (фразеологізм) та ін. Зазвичай вживання цих засобів мовлення сприяє утворенню медіативної перипетії; переключає на інший регістр сприйняття якогось явища, найчастіше з сумного - на сатиричне чи комічне.

10. Медіація формується при використанні Біблійних зразків:

О святые, великие, верховные апостолы! Если бы вы знали, как мы запачкали, как изуродовали провозглашенную вами простую, прекрасную, светлую истину! Вы предрекали лжеучителей, и ваше пророчество сбылось. Во имя святое, имя ваше, так называемые учителя вселенские подрались, как пьяные мужики, на Никейском вселенском соборе ${ }^{17}$.

Таких відверто сакральних інвектив у щоденнику багато і вони виконують роль емоційного й інтелектуального переключення з суєтного повсякдення на божественний простір буття.

Романтична медіація Т. Шевченка у «Журналі» перемістилась із області, що характерна для романтизму, трансцендентного до побутового, яке мислиться поетом майже трансцендентно, ірреально, недосяжно. Провідною ознакою Шевченкової медіації у щоденнику є саме дорівняння побутовізму до трансценденції, адже поет марить цивільним щоденним життям, жадає поринути в нього. Така особливість медіативного спрямування тексту, звичайно, легко пояснюється конкретною життєвою ситуацією Т. Шевченка. Щоденник писався напередодні звільнення від солдатської служби з великим очікуванням простого затишку повсякдення цивільного життя. Для поета це звичне родинне тепле давно перейшло до сфери трансцендентного і тому романтичне переселення медіаторів до сфери трансценденції у даному разі дотримане.

На терапевтичну функцію щоденника Шевченка вказав Олег Єгоров:

\footnotetext{
15 Ibidem, s. 51.

16 Ibidem, s. 54.

17 Ibidem, s. 59.
} 
Насамперед Шевченко хоче забути жахи солдатчини, позбутись спогадів про десятиріччя каторги невибагливим побутописанням - це його перша праця, до якої ніхто не примушує. Солдатське минуле він хоче викреслити з життя, і тому, як і Кюхельбекер, який писав у своєму тюремному щоденнику зовсім сторонні теми, ігнорує чисто солдатську тематику ${ }^{18}$.

При цьому медіатором стає звичайне життя з його дрібними турботами, наповнене побутом та без обтяжливих обов'язків. Тобто те, що зазвичай не підпадає під поетичне романтичне увічнення. Сам Шевченко говорить про терапевтичну функцію щоденника: «Сей журнал, который в эти томительные дни ожиданий сделался для меня необходимым, как страждущему врач» ${ }^{19}$.

Можемо говорити про нарощування медіативної змістовності щоденника Т. Шевченка від простих сповнених побутовими подіями-медіаторами записів - до записів, що мають естетичне наснаження та відображають формування літературних ідей та оцінок. Якщо на початку «Журнала» автор випромінює радість від простого вивільнення від солдатської служби (дозволили гуляти в саду та на городі комендантші), то, покидаючи Новопетрівське укріплення, він все більше розповідає про цікавинки свого культурного життя, про нових друзів та гостини. Якщо перші записи - це побутописання з відповідною медіацією тяжіння до такого простого життя, то дедалі більше з'являється емоційно-піднесених коментарів, що викликані культурним життям, і вершиною таких записів є захват, високий емоційний сплеск, з яким він сприйняв поезію М. Лермонтова.

Так сталось, що медіативна орієнтація щоденника Шевченка, змінюючись у зазначеному напрямі, затягнула до увічнення і культурні переживання поета, і його побутове життя. Насолода від першого і другого майже дорівняна. Аналіз медіативного спрямування щоденника Тараса Шевченка свідчить про щирість

\footnotetext{
18 Ibidem, s. 54.

19 Ibidem, s. 66.
} 
діариста так само, як і про втрату відчуття цензури, самоконтролю тощо. Коли щоденник пишеться «на замовлення» або заздалегідь планується автором до друку, то його медіація формується цілеспрямовано та однотипно; тут же ми маємо справу iз стихійно сформованою різноспрямованістю щоденникових записів. Особливість щоденникової медіації полягає в ії посиленій детермінованості контекстом життя письменника, тому текст відображає авторське уявлення про бажане, але недосяжне так само, як це ми спостерігаємо в художніх текстах романтиків, але ця щоденникова медіація накладається на життєві спонуки самого автора, які можна перевірити, які є фактами його життя, мають відповідних свідків. Звичайно, автор вільний у способі маскування або відтворення щоденникової медіації, але позбутись іï він не владний.

\section{References}

Bovsunivska T. V., Poet yak transtsendentnyi mediator $v$ literaturi romantyzmu [w:] Literaturoznavchyi dyskurs vid baroko do postmodernu: Kolektyvna monohrafiia, up. i nauk. red. N. Levchenko, Maidan, Liublin-Kharkiv 2020, s. $365-379$.

Ehorov O. H., Russkyi literaturnyi dnevnyk XIX veka. Ystoryia y teoryia zhanra, Flinta, Nauka, Moskva 2003.

Mesterhazy E. H., Lyteratura non-fykshn/non-fiction. Eksperymentalnaia entsyklopedyia, Sovpadenye, Moskva 2007.

Shevchenko T., Dnevnik, Goslitizdat, Moskva 1954.

Zhyrar R., Lozh romantyzma y pravda romana, per. s frants. A. Zyhmonta, Novoe lyteraturnoe obozrenye, Moskva 2019. 


\title{
Mirosław Nagielski \\ University of Warsaw (Poland) \\ ORCID: 0000-0003-4873-4313
}

\section{Diariusz wojny smoleńskiej Władysława IV (1633-1634)}

\section{Diary of the Smolensk war of Władysław IV (1633-1634)}

\begin{abstract}
:
Władysław IV Smolensk campaign is well described both in historical works and sources including diaries of Mikhail Borisovich Shein. One of these diaries now kept Riksarkivet in Stockholm describes military activities from the coming of relief force organized by Władysław IV in September 1633 to the Treaty of Polyanovka signed in June 1634. It contains previously unknown information about battles of Smolensk, Polish-Lithuanian Commonwealth troops march, complex relationships between hetmans, difficulties of army provisioning, officers and soldiers of various types of units. Thanks to the documents from the theatre of war we are able to reconstruct the structure of the officer cadre of the Polish-Lithuanian Commonwealth and the Muscovite forces. Also noteworthy are relations of Registered Cossacks comprised special units of the Polish-Lithuanian Commonwealth that came to present in front of the king. The Diary mainly describes military activities until the surrender of Shein, leaving little space to describe the struggle on the Biała in spring 1634. That event is described in every detail in the diary of John Moskorzewski.
\end{abstract}

Keywords: Władysław IV, Smolensk, Cossacks, diary, Shein, foreign haul

Historycy zajmujący się dziejami kampanii smoleńskiej Władysława IV mają bogatą podstawę źródłową w postaci wielu diariuszy, pamiętników, edycji korespondencji z lat 1632-1634, gdy Moskwa rozpoczęła działania zmierzające do odzyskania Smoleńska - kluczowej twierdzy na pograniczu litewsko-moskiewskim. Do nich należą 
m.in. opublikowany w 1895 r. diariusz przez A. Rembowskiego ${ }^{1}$, diariusz ekspedycji smoleńskiej począwszy od 25 sierpnia 1633 roku wydany jako dodatek do znanej pracy O. Celeviča o udziale w tej wojnie Kozaków zaporoskich ${ }^{2}$, fragmenty diariusza tej wojny począwszy od 4 września 1633 roku wydany przez A. Szałandę 3 . Szeroko omówił źródła do tej kampanii W. Lipiński ${ }^{4}$ oraz K. Liske, który zajął się głównie relacjami agenta elektora brandenburskiego Weinbeera i diariuszem podróży Adama Oleariusa von Ascherslebena, wysłannika księcia Fryderyka Holsztyn-Gottorp do Persji, który dotarł także pod Smoleńsk w trakcie walk z siłami Michała Borysowicza Szeina. ${ }^{5}$ Jednym z najistotniejszych diariuszy dotyczących tego okresu jest znajdujący się w zbiorach mikrofilmów Archiwum Głównego Akt Dawnych w Warszawie w tzw. zbiorze Extranea IX Polen nr 140 (awizy do 1644 r. - mkf. 73), którego oryginał znajdujemy w sztokholmskim Riksarkivet pod tytułem „Relation och Diarium Rorande Smolensks Undsatting 1633”. Był on sporządzany przez jednego z kancelarzystów Jakuba Zadzika kanclerza w. kor. Strona tytułowa sugeruje, iż mamy do czynienia z „Relatią z obozu JKMci, a naprzód na Głuszycy, gdzie najpierwej JKMść przyszedszy szczęśliwie pod Smoleńsk obozem stanął die 2 septembris in Anno 1633" doprowadzoną do dnia 14 grudnia tr., tj. gdy główny obóz moskiewski Szeina był już szczelnie otoczony przez siły polsko-litewskie. ${ }^{6}$ Po tej dacie autor diariusza zaznaczył, iż dołącza drugą część diariusza, która winna zaczynać narrację całej

1 J. Moskorzewski, Dyaryusz wojny moskiewskiej 1633 roku, wyd. A. Rembowski, Warszawa 1895.

2 O. Tselevich, Uchast kozakiv v smolensii viini 1633-4 rr., "Zapysky Naukovoho Tovarystva imeni Shevchenka”, t. XXVIII, 1899, s. 31-68.

3 A. Szałanda, Dyjaryusz Maskouskaj wajny u 1633 godze, „Commentarii Polocenses Historici”, t. III, Połock 2006, s. 50-64.

${ }^{4}$ W. Lipiński, Materiały i źródła do wojny smoleńskiej (1632-1634), „Przegląd Historyczno-Wojskowy", t. II, Warszawa 1930, s. 119-141.

${ }^{5}$ K. Liske, Przyczynki do historii wojny moskiewskiej z lat 1633-1634, „Biblioteka Ossolińskich", T. XI, 1868, s. 1-65.

${ }^{6}$ Diariusz kampanii smoleńskiej Władysława IV 1633-1634, oprac. M. Nagielski, Warszawa 2006, s. 102-193. 
kampanii smoleńskiej. Druga jego część nosi tytuł „Fragmenta diariusza ab augusto mense, jako się KJMść z Orszy ruszył ku Smoleńskowi z wojskiem; ten diariusz miał być naprzód pisany, ale to łacno się może redigi ad ordinem". Ta część kończy się na edycji traktatu pokojowego z Moskwą w dniu 13 czerwca 1634 roku z wyszczególnieniem wszystkich komisarzy Rzeczypospolitej, którzy brali udział w rozmowach ze stroną moskiewską. ${ }^{7}$

Informacje zawarte w poszczególnych diariuszach wzajemnie się uzupełniają, gdyż ich autorzy zwracali uwagę na inne wydarzenia, które miały miejsce nie tylko pod Smoleńskiem, ale pod Waźmą i Dorohobużem, gdzie znajdowały się zapasy aprowizacyjne dla armii M. B. Szeina. Oczywiście dominują relacje z działań sił polsko-litewskich pod twierdzą smoleńską zmierzające do odblokowania jej i zmuszenia sił moskiewskich do opuszczenia blokhauzów otaczających Smoleńsk. Wiele miejsca poświęcili autorzy tych doniesień Kozakom zaporoskim, którzy w kilku partiach przybywali na pomoc wojsku Rzeczypospolitej, chcąc się także zaprezentować nowemu władcy Władysławowi IV. W pierwszej grupie już 17 września pod Smoleńsk przybyli Kozacy pod wodzą Tymosza Orendarenki. Dwa dni później kronikarz zanotował wkroczenie całego korpusu kozackiego do obozu JKMci znajdującego się na wzgórzu Hłuszycy pod dowództwem Tymofieja Michajłowicza. Wzmianek o aktywnych działaniach oddziałów kozackich pod Smoleńskiem mamy wiele. Przykładowo z awiz z 25 września wynika, że „tejże nocy Kozacy Zaporowscy wpław Dniepr przeszedszy Francuza ingeniera i dwóch Niemców przywiedli i KJM oddali z bratią ruską, za którą dano im dwa cebry miodu i talarów 20"8. Wobec coraz trudniejszej sytuacji Szeina do oddziałów kozackich pozostających w służbie Rzeczpospolitej zaczęli przybywać z jego armii Kozacy dońscy. Pod datą 24 października czytamy w diariuszu smoleńskim, iż „do Kozaków Zaporowskich zaprzedało się kilka nieprzyjacielskich, powiadając iż wielka się w nieprzyjacielskim wojsku szkoda stała, bo w onegdajszej

\footnotetext{
7 Ibidem, s. 193-316.

8 Ibidem, s. 223.
} 
potrzebie wiele przednich oficierów pozabijano"9. Czytelnik przeglądający awizy z pola walki często znajduje na kartach tych doniesień informacje o walczących Kozakach; tylko z kontekstu można wywnioskować, czy chodzi o „naszych” Kozaków zaporoskich, czy dońskich przyprowadzonych przez Szeina pod mury Smoleńska i pozostających w służbie moskiewskiej czy wreszcie mowa o kozakach ale w tym wypadku chodzi o towarzyszy służących w wojsku polsko-litewskim ale po „kozacku” czyli w chorągwiach lżej uzbrojonych od ciężkozbrojnej husarii. Prezentowany diariusz wzbogaca naszą wiedzę nie tylko o przygotowaniach strony polsko-litewskiej do tej kampanii, przemarszu tych sił pod twierdzę smoleńską, konfliktach jakie miały miejsce pomiędzy żołnierzami z obu zaciągów narodowego i cudzoziemskiego (rajtarii, dragonii i piechoty niemieckiej) czy wreszcie o mało znanych konfliktach w łonie naczelnego dowództwa. $\mathrm{Na}$ porządku dziennym były spory pomiędzy hetmanami, tj. hetmanem polnym lit. Krzysztofem Radziwiłłem i hetmanem polnym kor. Marcinem Kazanowskim. Do sporów dochodziło od momentu pojawienia się odsieczy na wzgórzach Hłuszycy gdyż odmienne koncepcje założenia obozu królewskiego mieli sami Litwini, tj. ww. K. Radziwiłł i wojewoda smoleński Aleksander Gosiewski. W diariuszu pod datą 2 września czytamy:

Stanął KLMść nad rzeką Lubną we dwóch mil lekkich od Smoleńska; tam radził jmp. wojewoda smoleński aby KJMść z wojskiem, z którym wjachał stanął nad rzeką Jasienną w pół mili dobrym, albo w mili małej od Smoleńska, tak żeby miał i brzeg Dniepru dla żywności od Orszy i Dąmbrownej i rzekę Jasienną; przemogła jednak rada jmp. hetmana W. Ks. Lit., który radził, żeby KJMść stanął nad Dnieprem w półtora mil od Smoleńska drogą prostą, ale dla przepraw trudną, jako się tego na oko doznało, że przez godzin blisko 16 pod Smoleńskiem wojsko stanąć nie mogło. ${ }^{10}$

${ }^{9}$ W każdej niemal korespondencji spod Smoleńska mamy wzmianki o działaniach wojsk kozackich; w dniu 25 października kronikarz zanotował: „Kozacy zaporowscy, których kilkanaście od Smoleńska z jmp. wojewodą smoleńskim [Aleksandrem Gosiewskim] z tę tam stronę przyjechali, dwu Szwedów oddali, których pod ostrożkami nieprzyjacielskimi dostali”; ibidem, s. 148-149.

10 Ibidem, s. 102; por. M. Nagielski, Kampania smoleńska Władysława IV (16331634) $w$ świetle diariusza kancelaryjnego $w$ Extraneach szwedzkich $A G A D$ [w:] 
Spory dotyczące zakładania generalnego obozu dla wojsk tak koronnych jak litewskich nie ustawały, co potwierdzają kolejne awizy obozowe z 10 września 1633 r. Jak donosił nieznany informator:

Kontrowersyje były niepotrzebne między pany hetmany, jeśli my do litewskiego obozu, czyli Litwa do naszego obozu wniść miała. Przewiódł stojąc mordicus przy swoim uporze pan hetman litewski [K.Radziwiłł] i tak 4 septembris doszła znowu unia z Litwą. Weszliśmy my do ich obozu i stanęliśmy prawie we środku, gdzie lubo nam ciasno barzo, patientia. ${ }^{11}$

Do poważnych incydentów dochodziło stale pomiędzy hetmanami, stąd monarcha w celu zablokowania ewentualnej odsieczy dla Szeina wysłał ku Dorohobużowi właśnie hetmana polnego kor. M. Kazanowskiego, przydając mu znającego ten teatr walki wojewodę smoleńskiego, aby tym samym nie dochodziło do dalszych animozji z K. Radziwiłłem. Potwierdzają to kolejne zapiski w diariuszu, gdzie pod datą 29 października 1633 r. czytamy: „Naszy pp. hetmani barzo się z sobą gniewają i nie mówią do siebie; widzę chce ich jednać JM. ks. kanclerz [Jakub Zadzik]"12. Informacje okazały się prawdziwe, gdyż kanclerz starał się mediować między hetmanami i ich godzić, którzy wyzwali się nawet na pojedynek. ${ }^{13}$

Tego typu diariusze, które szczegółowo przedstawiają działania wojenne, atmosferę panującą wśród kadry dowódczej, stosunki pomiędzy żołnierzami różnych rodzajów broni ukazują także skład społeczno-narodowy armii polsko-litewskiej biorącej udział w walkach o uwolnienie Smoleńska od oblężenia przez siły moskiewskie. Wymienieni są także wyżsi dowódcy armii M. B. Szeina, w skład bowiem jego kadry oficerskiej wchodzili zaciągnięci przez płka Aleksandra Leslie'go Anglicy, Szkoci, Niemcy i Francuzi, którzy stali na czele cudzoziemskich pułków w armii moskiewskiej. Z korespondencji

Od armii komputowej do narodowej. Dzieje militarne Polski i jej wschodnich sasiadów od XVI do XX wieku, pod red. M. Krotofila i A. Smolińskiego, Toruń 2005, s. 28-29.

${ }^{11}$ Diariusz kampanii smoleńskiej Władysława IV, s. 212-213.

12 Ibidem, s. 153.

13 Zob. J. Dorobisz, Jakub Zadzik (1582-1642), Opole 2000, s. 217. 
wchodzącej w skład narracji diariuszy dowiadujemy się jak działała kancelaria Rzeczypospolitej w dobie tej kampanii, w której uczestniczył sam monarcha. W obozie przyjmowano bowiem poselstwa i sporządzano przez kancelarzystów tak J. Zadzika jak podkanclerzego lit. Pawła Stefana Sapiehy instrukcje dla posłów, dowódców działających na innych teatrach operacyjnych. Najistotniejsze jednak dla badających życie codzienne obozowe w tym okresie są prezentowane $\mathrm{w}$ edytowanych awizach scenki rodzajowe, tj. wydarzenia, które nigdy nie pojawiłyby się w innych formach przekazu. W diariuszach bowiem poza licznymi awizami $\mathrm{z}$ teatru działań znajdujemy korespondencję prywatną urzędników, szlachty, księży i innych osób obecnych pod Smoleńskiem, które informowały swych najbliższych o sytuacji, dzieląc się uwagami nt. tak prowadzenia działań ale także opisując incydenty jakie miały miejsce w trakcie całej tej kampanii. Przykładem może być zatarg jaki miał miejsce podczas przemarszu wojsk koronnych pod Smoleńsk w Borysowie w trakcie przemarszu wojska w kierunku Orszy. Do krwawego zatargu doszło przypadkowo a powód dali pacholik spod roty husarskiej dworzańskiej króla i woźnica spod jednej z kompanii regimentu gwardii pieszej JKMci pod płkiem Reinholdem Rosenem. Obaj pili w karczmie w Borysowie a woźnica napominany przez pacholika $\mathrm{z}$ roty dworzańskkiej nie chciał uiścić rachunku karczmarce. Doszło do bijatyki a na pomoc obu przybiegło $\mathrm{z}$ jednej strony towarzystwo husarskie a $\mathrm{z}$ drugiej rzesze piechotnych Rosena. Oddajmy zatem głos autorowi tej relacji:

Gdy się sami biją, gruchnęło to i z obu stron hultajstwo im przybywało do posiłku; tam iż woźnice królewscy w większej liczbie byli bo zewsząd im na pomoc Rożnowa piechota biegła, przyszło szwankować onemu pacholikowi i usarzom dworskim; aż potym z obu stron zajuszywszy się do tego przyszło, że chorągiew dworską in consulte podniózszy wyszli w pole przeciwko Rożnowym, tam $\mathrm{w}$ tym tumulcie chorągiew królewska zdrapana i znieważona. ${ }^{14}$

Widząc przewagę chłopstwa, towarzystwo husarskie wyzwało na pojedynek oficerów piechoty JKMci, a sam pan Skarszewski wyzwał

${ }^{14}$ Diariusz kampanii smoleńskiej Władysława IV, s. 199. 
samego obersztera Rozena. Król jednak powiadomiony o zajściach zakazał pod gardłem pojedynków, a winnych postawiono przed sądem hetmańskim. „Sądzono potym iudiciarnie te rzeczy, ale siła ich sarka na to że mitius niż beło trzeba skarano authores, bo ścięto telko jednego czy drugiego hajduka,a o zdrapanie dwudziestu woźnic kijmi bito,a to przepadło co z Usarzów nabito i nakaleczono". ${ }^{15}$

W diariuszu znajdujemy informacje dotyczącą problemów z wystawieniem chorągwi dworzańskiej Władysława IV, która stanowiła bezpośrednią ochronę monarchy. W jej skład wchodzili dworzanie JKMci, którzy wraz z pocztami mieli stawić się do obozu gdy w wyprawie wojennej uczestniczył monarcha. W kampanii smoleńskiej z wystawieniem tej roty były niemałe problemy, gdyż wielu dworzan królewskich uchylało się od tego obowiązku. Wojna $\mathrm{z}$ Moskwą toczona $\mathrm{z}$ reguły daleko od centralnych prowincji Korony, w trudnych warunkach klimatycznych nie skłaniała ich do wystawienia drogich pocztów husarskich. Pod koniec sierpnia $1633 \mathrm{r}$. w obozie pod Orszą monarcha nadal oczekiwał nie tylko na leniwie ciągnące regimenty ale także na opóźniających się dworzan. Z awiz spisanych w obozie orszańskim z 26 sierpnia tr. wynika, iż w tym czasie „poczty prezentowali pp.dworzanie: sześć tylko pocztów litewskich a siódmy p. starosty rózańskiego [Wojciecha Wessla]. KJMść barzo sollicitus, że się regimenty nierychło pospieszają mianowiecie p. Arciszewskiego [Eliasza], p. Weihera [Jakuba], pp. Radziwiłłów [Janusza] podkomorzego litewskiego i [Zygmunta]kawalera [maltańskiego] książęcia i Wolsona ${ }^{16}$. PP.pokojowych tu o male barzo aż spod chorągwie Króla JMci towarzystwo ${ }^{17}$ do ubierania i rozbierania przyjeżdżają i z tych wszystka assistentia przed pokojem"18. Sytuacja nie uległa poprawie, a do tego doszło do sporów między Litwinami

\footnotetext{
15 Ibidem, s. 199-200.

16 Chodzi o płk. Jakuba Wallisona stojącego na czele regimentu liczącego 800 porcji piechoty; zob. komput wojsk królewskich zaciągniętych na wojnę smoleńską w 1633 r.; D. Kupisz, Smoleńsk 1633-1634, s. 244-245.

17 Chodzi o towarzystwo spod chorągwi husarskiej KJMci pod komendą Mikołaja Stogniewa będącej w służbie wojsk kwarcianych.

18 Diariusz kampanii smoleńskiej Władysława IV, s. 195-196.
} 
i Koroniarzami, kto ma być dowódcą roty dworzańskiej. W obozie pod Bajowem 28 sierpnia „poczty naszy dworzanie pokazowali, litewskich coś więcej niżeli koronnych, a koronnych zaledwo trzech, co barzo exprobant Domini Lithuani i za porucznika p. Wyszla starostę różańskiego do chorągwie KJMci dworskiej nie chcą przyjść, powiadając że nas więcej (jakoż tak jest, bo ich będzie do trzechset koni przy których i piechot różnych pocztowych także do 400) i służalszych, choć jednak i kto inszy będzie, nie tuszę aby chorągiew królewską rozwinąć miano; przyjdzie podobno na czas dworzańskim pocztom podjechać pod chorągiew starą Króla JMci pieniężną p. Stogniewa"19. Stale jednak dochodziło do drobnych incydentów między żołnierzami i oficerami, którzy wrażliwi byli na pomijanie ich w czynieniu honorów wobec króla. Walczono o tego typu sprawy jak zajmowanie odpowiedniego miejsca w szyku wojska czy w sprawianiu asystencji towarzyszącej Władysławowi IV w trakcie jego pochodu ku twierdzy smoleńskiej. Jeden z kancelarzystów zanotował, iż w obozie pod Bajowem doszło do poważnego incydentu między gwardią rajtarską króla a podkomorzym podolskim Marcinem Kalinowskim. Oto co czytamy w awizach z 28 sierpnia:

Pana Kalinowskiego podkomorzego podolskiego, że zwadę zaczynał, i z rajtarami Króla JM ${ }^{20}$ certował o praeminentią szcia bliższego za Królem JM. zawiązał p. hetman koronny [Marcin Kazanowski ] ślubem rycerskim, rozumiemy jednak, że wyjdzie z tego kłopotu, zwłaszcza gdy się nic złego z tej zwady nie stało. ${ }^{21}$

Wiele informacji uzyskujemy na temat przechodzenia $\mathrm{z}$ armii Szeina na stronę polsko-litewską żołnierzy z oddziałów Szeina, głównie byli to cudzoziemcy, którzy widząc iż szala zmagań przechyla się na rzecz polskiego monarchy decydowali się porzucić służbę moskiewską. Dzięki tym wzmiankom pochodzącym z diariusza

\footnotetext{
19 Ibidem, s. 200-201.

${ }^{20} \mathrm{Na}$ czele roty rajtarskiej KJMci liczącej 120 koni stał Jan Sey-Manteuffel; zob, Wojsko KJMci na ekspedycyja moskiewskg 1633 r. [w:] Diariusz kampanii smoleńskiej Władysława IV, s. 336.

21 Ibidem, s. 203.
} 
możemy określić skład korpusu dowódcy moskiewskiego pod względem narodowościowym. Wielu z oficerów pochodzących ze Szkocji, Anglii czy Holandii zostało zwerbowanych przez płka Aleksandra Lesley’a. Zawiedzeni warunkami w służbie carskiej i trudnościami życia obozowego w blokowanym przez siły polsko-litewskie obozie wojsk Szeina rezygnowali ze służby w siłach moskiewskich. Pierwsze dezercje żołnierzy moskiewskich obserwujemy już we wrześniu 1633 roku. Pod datą bowiem 26 tm. czytamy w diariuszu: „Języków nieprzyjacielskich z piechoty ośm się przedało, jeden porucznik obersztera Szarlego"22. Kilka dni później ponownie zdezerterowało kilkunastu żołnierzy, którzy złożyli relacje o sytuacji panującej w blokhauzie Szymona Prozorowskiego. Dnia 30 września „ku wieczorowi czternaście cudzoziemców przedało się powiadając, że Prozorowski w trzech milach od Seyna stanął sturbowany, dając przyczynę ustąpienia jego,że Damm $^{23}$ słysząc w nocy, że naszy koło zamków opanowanych pilno robią"24. W kolejnych miesiącach wobec pogarszającej się sytuacji oddziałów Szeina niemal każdego dnia przybywali cudzoziemcy, rezygnując ze służby carskiej i prosząc o paszporty umożliwiające im swobodny wyjazd z Rzeczypospolitej do własnych krajów. Niektórzy z nich godzili się przyjąć służbę u Władysława IV zaskoczeni niezwykle przyjaznym stosunkiem do nich polskiego monarchy. Pod datą 3 października czytamy w diariuszu, iż „tegoż dnia zaprzedało się do nas Anglików kilkanaście nieprzyjacielskich"25. Wielce interesujące w tym zakresie są awizy z 21 i 28 listopada tr. informujące o coraz trudniejszej sytuacji

22 Ibidem, s. 114. Byli to żołnierze z pułku Jakuba Charley’a złożonego z cudzoziemców zwerbowanych w Anglii i Holandii, który miał liczyć 911 ludzi. W. Lipiński, Stosunki polsko-rosyjskie w przededniu wojny smoleńskiej 1632-1634 i obustronne przygotowania wojskowe, „Przegląd Historyczno-Wojskowy”, t. IV, Warszawa 1931, s. 259-260.

${ }^{23}$ Indrykt van Damm - Holender w służbie moskiewskiej, stał na czele piechoty „sołdatskiej” złożonej z żołnierzy moskiewskich; D. Kupisz, Smoleńsk 16321634, s. 69.

${ }^{24}$ Diariusz kampanii smoleńskiej Władysława IV, s. 122-123.

${ }^{25}$ Ibidem, s. 127. 
panującej w obozie wojsk moskiewskich Szeina: „Języków nieprzyjacielskich do 20 przedało się do nas, którzy tam o wielkim głodzie powiadają a między inszemi rzeczami jałowiczego mięsa ani widać. Ci na Moskwę, ba i na oficerów swych barzo narzekają,że wszystko udawali, że jest dosyć żywności, a w rzeczy samej jej nie masz" ${ }^{26}$. $\mathrm{Z}$ kolei pod datą 28 listopada zanotowano:

Dwaj Angielczykowie przedali się do Smoleńska i kilka Francuzów i Niemców, których wszystkich 30 kilka przyszło ze Smoleńska o paszporty, które im KJMść dać kazał i po piąciu talarach na drogę. A tym co na służbę JKMci przystają po dziesięciu. $Z$ tych chorąży jeden $\mathrm{z}$ Stralsundu rodzie powiedział iżby wszyscy cudzoziemcy żołdaci odeszli od nieprzyjaciela kiedyby wiedzieli tu o takiej prędkiej łaskawej odprawie i innych wiele rzeczy referował. ${ }^{27}$

Dzięki zeznaniom dezerterów strona polsko-litewska doskonale wiedziała o sytuacji w obozie Szeina oraz upadającym morale i dyscyplinie wśród jego żołnierzy. Łagodne traktowanie uciekinierów z obozu moskiewskiego, obdarowywanie ich żywnością i pieniędzmi dotarło do obozu nieprzyjacielskiego stąd odnajdujemy w diariuszu dalsze wzmianki o masowym porzucaniu służby carskiej głównie przez cudzoziemców zwerbowanych przez agentów cara Michała Romanowa w Anglii i Niemczech. Szczególnie interesująca jest jedna relacja zamieszczona pod datą 3 października 1633 r., gdzie dzięki ich zeznaniom dowództwo polsko-litewskie uzyskało informacje o przygotowaniach Szeina do odwrotu i porzuceniu dotychczasowych obozowisk. W awizach obozowych czytamy bowiem:

Angielczykowie coraz od nich do nas się przedają; już do trzechset paszportów z kancelaryjej wydano im do patriej accepto a Reg. Maiestate honorario odchodzą, a drudzy w służbie zostawają u nas. Siła tu tego od nieprzyjaciela przedaje się, Francuzi, Szkoci, Szwedowie. Już tedy ze trzech stron wolny Smoleńsk, z jednej jeszcze stronę w szańcach się trzymają, ale niedługo jako przedawczykowie powiadają, tylko dział pięć wielkich burzących, odbierzeć się im nie chce choć po 200 człeka w nie zaprzągają, a ruszyć ich nie mogą

26 Ibidem, s. 174.

27 Ibidem, s. 178. 
z miejsca; po półtorasta rubli na żołdata jednego dają od jednej sztuki a nihil dotąd effecerunt, na ostatek chcą je prochami rozsadzić, jeżeli ich nie będą mogli uwieść. ${ }^{28}$

Nie oznaczało to wcale, że dezercje miały miejsce tylko z obozu moskiewskiego. Kancelarzyści skrupulatnie wynotowywali także przypadki przechodzenia z obozu polsko-litewskiego żołnierzy do blokhauzów nieprzyjacielskich. Były to jednak wypadki sporadyczne ,ale mające miejsce. I tak w listopadzie 1633 r. „kuśnierz jeden uciekł od nas do Moskwy bojąc się karania dlatego, iż więzień jeden od nas do Moskwy Moskwicin nazwany Trzeciakow, z którym on przestawał i który $\mathrm{w}$ nim $\mathrm{w}$ jednej budzie mieszkał uciekł do nieprzyjaciela zabrawszy mu cudzych rzeczy z sobą"29. Głównie na stronę moskiewską przechodzili prości żołnierze i podoficerowie wobec trudnej sytuacji aprowizacyjnej w obozie polsko-litewskim i kłopotami w wypłacie żołdu głównie dla jednostek zaciągu cudzoziemskiego. Z awiz z 15 listopada 1633 r. dowiadujemy się ,że „oficer jeden, sierżant p.Arciszewskiego ${ }^{30}$ przedał się do nieprzyjaciela bo się pierwej od niego do nas był zaprzedał, co p. Arciszewskiego do obwarowania gruntownie ostróżka tym więcej pobudziło", w celu ograniczenia dezercji z jego pułku. ${ }^{31}$

$\mathrm{Z}$ diariusza dowiadujemy się o wielu problemach natury logistycznej związanych $\mathrm{z}$ zaopatrzeniem wojska $\mathrm{w}$ proch, muszkiety a także kłopotami $\mathrm{z}$ wyposażeniem korpusu artyleryjskiego. Na ciągły brak dobrze wyszkolonych artylerzystów uskarżało się wielu dowódców $\mathrm{w}$ trakcie prowadzenia działań wojennych. W tym przypadku korzystano z potencjału jakim dysponował Gdańsk, przez który ściągano aparaturę wojenną aż pod Smoleńsk. $Z$ awiz obozowych z 14 stucznia 1634 r. dowiadujemy się bowiem, że „Armata ze Gdańska nowej roboty stanęła już w obozie, kartaunów dwanaście sztuk,

\footnotetext{
${ }^{28}$ Ibidem, s. 227.

${ }^{29}$ Ibidem, s. 168.

30 Chodzi o płka Eliasza Arciszewskiego dowódcy regimentu piechoty niemieckiej liczącego 800 ludzi; zob. D. Kupisz, Smoleńsk 1632-1634, s. 244.

${ }^{31}$ Diariusz kampanii smoleńskiej Władysława IV, s. 168.
} 
moździerzów trzy i insze instrumenta i potrzeby do nich należące, także i puszkarzów 20 posłano do gdańszczan, bez których nam tu barzo źle beło, bo się jeden przed kilką niedziel przedał do nieprzyjaciela, drugiego zabito, i tak ledwieśmy mieli puszkarzów dwóch" 32 . Sytuacja pod tym względem znacznie się poprawiła, gdyż w wyniku kapitulacji armii Szeina strona polsko-litewska przejęła znaczne zasoby artylerii, broni ręcznej i innych rzeczy nieodzownych do prowadzenia wojny.

W spisie zamieszczonym w omawianym źródle wymieniono aż 103 działa różnych wagomiarów, siedem moździerzy, prochu kadzi 68, kul do dział fas 18, ołowiu kap 200 oraz „muszkietów, zbroj, konnych i pieszych, szpad, rydlów,żelaz rozmaitych i w sztukach wielkich knotów, lin niezliczona i niezmierna rzecz wzięta" 33 . Większość z wymienionej aparatury wojennej została przewieziona do twierdzy smoleńskiej, która niemal przez rok skutecznie odpierała ataki sił moskiewskich. W opisach ukazujących życie codzienne obozowe nie brakuje ciekawych informacji dotyczących bezpośrednio osoby królewskiej i towarzyszącego mu w tej kampanii brata Jana Kazimierza. Okazuje się, że wiele szczęścia mieli obaj gdy lustrowali pozycje własnej piechoty i pole bitewne w początkowym okresie walk o odblokowanie Smoleńska. W przesyłanych awizach za okres od 29 września do 1 października czytamy:

Tegoż dnia nim poczęto strzelać, królewicz JM Kazimierz szedł sobie piechotą samoczwart ku obozowi nieprzyjacielskiemu polem opodal przecie, kiedy strzelba dała się słyszeć nieprzyjacielska, ku naszemu obozowi na piechotę udał się Królewicz JM, schyliwszy głowę samoczwart, nadbieżało go dwaj towarzystwa spod chorągwie p. wojewody smoleńskiego [Aleksandra Gosiewskiego] przy nim szli, jeden z nich idąc za Królewiczem JM po prawej ręce chciał na drugą stronę przejść , to jest na lewą idąc zaszedł za Królewicza JM, w tym go kula w łeb uderzyła i padł zaraz na ziemię i tam bez dusze został w polu, dziękował zaraz Panu Bogu Królewicz JM za takową tarczę, którą mu na ten czas zesłał dla obrony zdrowia jego, bo go to prosto za królewiczem potkało.

32 Ibidem, s. 255.

33 Zob. Komput dział, które Moskwa według umowy tabor oddając Królowi JMci zostawić i z insza municyja musiała [w:] Diariusz..., s. 290-291. 
Przed namiotem KJM blisko barzo lokajowi kula nogę odcięła. Jadąc KJM tego dnia kiedy nieprzyjaciel z ostrożków swych pouciekał, kula z działa przed końcem ( na którym sam KJM jachał) w ziemie uderzyła i wszystkiego ziemia osypała. ${ }^{34}$

Tego typu incydentów znajdujemy w diariuszu wiele, które kancelarzyści eksponują i co mogło zainteresować czytających te awizy z pola walki.

Mimo, że kampania smoleńska należała do największych sukcesów Władysława IV i Rzeczypospolitej w starciach z Moskwą, nie pomijano kwestii trudnych ukazujących mankamenty zarówno odnoszące się do prowadzonych działań, struktury armii, postawy oficerów i żołnierzy i ich morale i dyscypliny, które często nie były na należytym poziomie, $W$ wielu miejscach diariusza znajdujemy wpisy informujące o skandalicznym zachowaniu szczególnie żołnierzy z chorągwi zaciągu narodowego. I tak pod datą 6 października, a więc po miesiącu walk pod Smoleńskiem, czytamy: „Tego dnia kilkanaście towarzystwa spod chorągwie p. Ogińskiego ${ }^{35}$ wytrąbiono iż ślubem od jmp. hetmana litewskiego [Krzysztofa Radziwiłła] zawiązani będąc wyjechali z obozu i służbę, nie mając przyczyny żadnej do rotmistrza, porzucili" 36 . Z podobnym zachowaniem się towarzystwa choragiewnego spotykamy się w opisie wydarzeń z 24 października, gdzie jeden z kancelarzystów zanotował: „Dawał trębacz termin pewnemu towarzystwu, którzy nie opowiedziawszy [się] p. hetmanowi spod chorągwie p. Czyża ${ }^{37}$ rotmistrza wyjechali, aby się stawili do sądu hetmańskiego"38. Przykro odebrał zapewne Władysław IV kłótnie związane z niechęcią wzmocnienia załogi Smoleńska po odblokowaniu tej twierdzy od oblężenia. Znając

34 Ibidem, s. 125.

$35 \mathrm{~W}$ tym przypadku chodzi o rotę husarską chorążego trockiego Aleksandra Ogińskiego; zob. Komput wojsk królewskich pod Smoleńskiem [w:] D. Kupisz, Smoleńsk 1632-1634, s. 242-244.

36 Diariusz kampanii smoleńskiej Władysława IV, s. 129.

37 Kiryk Czyż rtm. chorągwi petyhorskiej w kompucie litewskim; zob: D. Kupisz, Smoleńsk 1632-1634, s. 243.

38 Diariusz kampanii smoleńskiej Władysława IV, s. 147. 
kłopoty aprowizacyjne załogi i dodatkowe obowiązki wynikające ze służby garnizonowej wielu pułkowników regimentów pieszych odmawiało wejścia w mury Smoleńska zapewne żądając dodatkowej zapłaty. Pod datą 7 września znajdujemy ciekawe uwagi na ten temat, wskazujące na nie najlepsze stosunki w gronie najwyższej kadry zaciągu cudzoziemskiego: „Regiment królewica JMci Kazimierza ${ }^{39}$ ,bo się drugie ociągały, z ochoty i rozkazania samego królewica JMci wszedł do Smoleńska bez żadnej wymówki spectante hoste most do Smoleńska przechodził, a drugie się regimenty z swemi oberszterami o to targowały. $\mathrm{O}$ czym bełoby siła pisać, ale czasu i bezpieczeństwa takiego nie masz" 40 . Widzimy zatem ,że diariusz przechowywany w zbiorach AGAD w Warszawie wzbogaca naszą wiedzę o kampanii smoleńskiej Władysława IV, prezentując nie tylko kolejne etapy zmagań pod twierdzą smoleńską ale ukazuje strukturę, organizację sił polsko-litewskich, skład korpusu oficerskiego oraz rzetelnie przedstawia także mankamenty jakie wystąpiły tak w trakcie przemarszu tych sił spod Wilna ku Smoleńskowi jak w trakcie samych działań wojennych. Uzupełnia zatem obraz tej kampanii jaki znajdujemy w diariuszu Jana Moskorzewskiego. Dopiero skonfrontowanie obu tych diariuszy wraz z innymi źródłami epoki, $w$ tym z szyfrowanymi depeszami obrońców Smoleńska kierowanymi do hetmana polnego lit. Krzysztofa Radziwiłła dają pełny obraz wydarzeń jakie miały miejsce pod murami twierdzy smoleńskiej w latach 1633-1634. ${ }^{41}$ Także wiele wzmianek w obu diariuszach dotyczących udziału oddziałów wojska zaporoskiego przybyłych pod Smoleńsk dla wsparcia sił polsko-litewskich świadczy, że Kozaczyzna zaporoska poparła w tym konflikcie Rzeczypospolitej z Moskwą Władysława IV, tym samym

${ }^{39}$ Chodzi o regiment piechoty niemieckiej Jana Kazimierza Wazy pod komendą ppłka Henryka Denhoffa, który w sile 1200 porcji wszedł do twierdzy smoleńskiej; zob. Wojsko KJMci na ekspedycyja moskiewska 1633 r. [w:] Diariusz kampanii smoleńskiej Władysława IV, s. 337.

40 Diariusz kampanii smoleńskiej Władysława IV, s. 211.

${ }^{41}$ Zob. M. Nagielski, Szyfrowane depesze Samuela Stanisława Sokolińskiego ze Smoleńska w 1633 r., „Miscellanea Historico-Archivistica”, t. XI, Warszawa 2000, s. 286-304. 
odwzajemniając się za podjęcie przez tego władcę nowego dialogu z Kozakami choćby w kwestii odtworzenia hierarchii prawosławnej i przekazania urzędu metropolity kijowskiego Piotrowi Mohyle. Wkład bowiem Kozaczyzny w działania prowadzone tak wobec Moskwy jak Turcji przeciwko siłom Abazy paszy w 1633 r. był znaczący, co podkreślają historycy opisujący pierwsze lata panowania Władysława IV. ${ }^{42}$

\section{References}

Antonowych M., Kozatske viisko u Smolenskii viini, Warszawa 1937.

Diariusz kampanii smoleńskiej Władysława IV 1633-1634, oprac. M. Nagielski, Warszawa 2006.

Dorobisz J., Jakub Zadzik (1582-1642), Opole 2000.

Franz M., Idea państwa kozackiego na ziemiach ukrainnych w XVI-XVII wieku, Toruń 2006.

Kupisz D., Smoleńsk 1633-1634, Warszawa 2001.

Lipiński W., Materiały i źródła do wojny smoleńskiej (1632-1634), „Przegląd Historyczno-Wojskowy", t. II, Warszawa 1930.

Lipiński W., Stosunki polsko-rosyjskie w przededniu wojny smoleńskiej 16321634 i obustronne przygotowania wojskowe, „Przegląd Historyczno-Wojskowy", t. IV, Warszawa 1931.

Liske K., Przyczynki do historii wojny moskiewskiej z lat 1633-1634, „Biblioteka Ossolińskich”, t. XI, 1868.

Moskorzewski J., Dyaryusz wojny moskiewskiej 1633 roku, wyd. A. Rembowski, Warszawa 1895.

Nagielski M., Kampania smoleńska Władysława IV (1633-1634) w świetle diariusza kancelaryjnego w Extraneach szwedzkich AGAD [w:] Od armii komputowej do narodowej. Dzieje militarne Polski i jej wschodnich sąsiadów od XVI do XX wieku, pod red. M. Krotofila i A. Smolińskiego, Toruń 2005.

42 Zob. M. Antonowych, Kozatske viisko u Smolenskii viini, Warszawa 1937; M. Franz, Idea państwa kozackiego na ziemiach ukrainnych w XVI-XVII wieku, Toruń 2006, s. 186-189; M. Nagielski, Wspótpraca sił Rzeczypospolitej z Kozaczyzna w I połowie XVII wieku dla obrony granic Rzeczypospolitej [w:] Polsko -Ukraińska wspótpraca wojskowa na przestrzeni dziejów, pod red. J. Odziemkowskiego, Oświęcim 2018, s. 30-33. 
Nagielski M., Szyfrowane depesze Samuela Stanisława Sokolińskiego ze Smoleńska w 1633 r., „Miscellanea Historico-Archivistica”, t. XI, Warszawa 2000.

Nagielski M., Wspólpraca sił Rzeczypospolitej z Kozaczyzna w I połowie XVII wieku dla obrony granic Rzeczypospolitej [w:] Polsko -Ukrainska wspólpraca wojskowa na przestrzeni dziejów, pod red. J. Odziemkowskiego, Oświęcim 2018. Szałanda A., Dyjaryusz Maskouskaj wajny u 1633 godze, „Commentarii Polocenses Historici, t. III, Połock 2006.

Tselevich O., Uchast kozakiv v smolensii viini 1633-4 rr., „Zapysky Naukovoho Tovarystva imeni Shevchenka", t. XXVIII, 1899. 


\section{Walentyna Sobol}

University of Warsaw (Poland)

ORCID: 0000-0003-0484-6874

\section{Пилип Орлик сам про себе}

\section{Pylyp Orlyk about himself}

\section{Abstract:}

This article explores various forms of self-presentation of the hetman on the path of self-knowledge in the conditions of hopelessness caused by emigration. Pylyp Orlyk's handwritten diary of 1725, 1726, and 1727 is dominated by motives of accustoming to emigration conditions, protection of privacy, discourses, illness and recovery, friendship, solitude with reading, and finally, more clearly than before, the self-awareness of the soul. "Peregrine", as Orlyk calls himself in 1727, after eighteen years of emigration. He orders two or three services at once for the children on their birthdays, for the health of his wife Anna of the Hercyk family. Orlyk visits all the churches in Thessaloniki, is a good Christian, but nowhere emphasizes his denomination. He believes in the power of praying for the health of his family and friends. Sincere prayer becomes medicine. One of the described disasters of that time is perceived today in a very modern way - "bad air". This euphemism is repeated in the manuscript when it comes to the plague pandemic in Thessaloniki, Smyrna, Istanbul.

Keywords: Emigration, prayer, privacy, friendship, discourses, reading, epidemic.

Альберт Ейнштейн стверджував, що $є$ тільки два способи прожити життя. Перший - ніби чудес не існує. Другий - ніби навколо тільки самі чудеса. Барокові его-документи, проаналізовані з перспективи чуда, увиразнюють не тільки сакральне, а й скеровують увагу дослідників у царину приватного життя. Окремі аспекти приватного життя гетьмана Орлика вже були 
в полі мого зору1. У цій статті звернімося до щойно розшифрованого рукопису Орлика з років $1725,1726,1727$, в якому крізь призму як реального, так і чудесного чіткіше окреслюється, як сам себе починає усвідомлювати Орлик після вісімнадцяти еміграційних років. Він переживає своєрідне осяяння, описане в бароковій літературі, як реакція на дивовижні з'яви, чудо, яке $\epsilon$ «втручанням безкінечного і безумовного в кінечне і випадкове, сходження вічного в історично однократне»². Як знаємо, спеціальні збірники чудес почали з'являтися в Україні від XVII століття. Найдавнішим вважається Сказання про чудесні й визначні явища в православній церкві Петра Могили. Сам титул виразно підкреслює інтенції. Цей почин - наголосити, що і в східній православній церкві також є місце чуду - спонукав Атанасія Кальнофойського до використання описів Могили і створення збірки Тератургима або Чуда (1638) - про чуда та незвичайні події в Печерському монастирі. Кальнофойський взяв участь у виданні іншої збірки чуд Парергон І.Денисовича. У 1676 Iоаникій Галятовський написав Скарбницю потребну й пожитечну про чуда в Почаївському монастирі. I врешті славнозвісна Гора Почаївська, яка видана вперше в 1742, але згодом були перевидання. Хоча маю відношення до цього тексту (мій переклад увійшов до виданої в 2012 збірки, яку впорядкував В.Шевчук³), але

${ }^{1}$ W. Sobol, Dyskurs życia prywatnego w „Diariuszu podróżnym” Filipa Orlika (ujęcie komparatystyczne) [w:] Memuarystyka w dawnej Polsce. Redakcja Piotr Borek, Dariusz Chemperek, Anna Nowicka-Struska. Wydawnictwo Collegium Columbinum, Kraków 2016, s.161-167.

2 S. Averyntsev, Chudo [w:] S. S. Averyntsev. Sofiia- Lohos. Slovnyk, vyd.Dukh i litera, Kyiv 1999, s. 204.

${ }^{3}$ Pro stipku chudovnu naisviatishoi Marii divy na Hori Pochaivskii ta yii davnist. Pereklad V. Sobol [w:] Skarbnytsia potrebna y pozhytochna. Ukrainski monastyrski litopysy, zhytiia, povchannia chentsiam, chuda ta inshe. Uporiadkuvannia, vstupna stattia ta komentari Valeriia Shevchuka, Vydavnytstvo «Lybid», Kyiv 2012, s. 414426. Skarbnytsia potrebna y pozhytochna. Ukrainski monastyrski litopysy, zhytiia, povchannia chentsiam, chuda ta inshe. Uporiadkuvannia, vstupna stattia ta komentari Valeriia Shevchuka, Vydavnytstvo «Lybid», Kyiv 2012, s. 414-426. Zob. Również: P.Chomik, Kult ikon Matki Bożej w Wielkim Księstwie Litewskim 
зупинюся на мотивах дивовижної витривалості та психічної стійкості автора барокового рукопису в світлі антропології пам'яті, яка вписується в традицію біографічних студій на базі власне пам'ятникарського матеріалу․․ Праця з рукописом дарувала певні несподіванки в тому, як автор усвідомлює себе і пише про себе, долаючи випробування емігрантської недолі, часом на хисткому пограниччі реального і неймовірного. Дефініція зі словника Яворського 5 окреслює додатковий сенс епіфанії. Від певного часу він уживається як відкриття ширшої перспективи на те, що невидиме, на сенс існування: аж після вісімнадцяти років вигнання в нотатці від 30 січня 1727 року Орлик вперше називає себе пілігримом у широкому значенні - „Ja iako peregring”. Уже не подумки (раніше він зізнався в цьому сам собі), а в ситуації, коли від нього очікували відповідь: «Uczyniłem tedy na to replikę, iż Ja iako peregring nie chcę się tu w żadne rzeczy mieszać...» ${ }^{6}$. У тій екстремальній ситуації викристалізовується розуміння невідворотності долі. Ситуацію, в якій Орлик це усвідомлює, теж можна окреслити як епіфанію: гетьман виявляє лояльність у стосунку до Далматинського єпископа, який збирав у Салоніках милостиню («jałmużnę») для руського монастиря на горі Афон. Орлик не підтримує надміру жорстких заходів салоніцького митрополита, хоча той $є$ його приятелем:

w XVI-XVIII wieku, Wydawnictwo Uniwersytetu w Białymstoku, Białystok 2003; Księga Cudów przed ikona Matki Boskiej Waśkowskiej dokonanych. Do druku przygotował i wstępem opatrzył Antoni Mironowicz, Wydawnictwo Uniwersytetu w Białymstoku, Białystok 2012; Księga Cudów przed ikona Matki Bożej w Starym Korninie dokonanych dokonanych. Do druku przygotował i wstępem opatrzył Antoni Mironowicz, Wydawnictwo Uniwersytetu w Białymstoku, Białystok 1997. ${ }^{4}$ M.Napiórkowski, Od teoretyzowania na temat praktyk do praktykowania teorii [w:] Antropologia pamięci. Zagadnienia i wybór tekstów. Wstęp i redakcja Paweł Majewski, Marcin Napiórkowski, Wydawnictwa Uniwersytetu Warszawskiego, Warszawa 2018, s. 12.

${ }^{5}$ S. Jaworski, Słównik terminów literackich, Universitas, Kraków 2007, s. 61.

${ }^{6}$ P. Orlyk, Diariush podorozhnii, yakyi $v$ imia Troitsi naisviatishoi, rozpochatyi $v$ roku 1720 misiatsia zhovtnia dnia 10-ho. Tom III, Vydavnytstvo «Tempora», Kyiv 2013, s. 314. 
Miał tedy posłać Ojciec Metropolita po tamtego Ep[isko]pa do wsi Hajwatowa dokąd on pojachał ztąd 17 huius z głową Ś[więtego] Pantelejmona dla poświęcenia wody, i zebrania na monaster Ruski jałmużny, chcąc go ztamtąd do siebie civiliter $^{7}$ sprowadzić, pod pretekstem pilnej z nim conferencyi, i za przybyciem Je[go] tu do Saloniku, patent swój odebrać, jeżeli będzie convictus ${ }^{8}$ w tym, jako mu o nim relacię uczyniono. Jeżeli tedy będe żyw, będę widzieć i wiedzieć exitum rei $i^{9}$.

Відчуваючи крихкість життя в непевності, Орлик шукає зміцнення духу у спілкуванні з природою, у поїздках до чудодійного джерела Агіазми, святої води. Віднайдення та відвідання одного iз таких джерел поза межами міста Салоніки (куди був зісланий Орлик) так вразило його, що в нотатках 1724 року віднаходимо його власноруч зроблену карту місцезнаходження Агіазми ${ }^{10}$. Це єдиний малюнок Орлика у його рукописі, на нього не звернув уваги жоден з трьох палеографів-трудівників, які в 1830 у Варшаві зробили скорочену копію ${ }^{11}$. Магдалена Любанська в праці Praktyki lecznicze $w$ prawosławnych monasterach $w$ Bułgarii ${ }^{12}$, написаній на підставі теренових досліджень у болгарських церквах та монастирях, оприявнює ті ж практики витривалості та зцілення, які триста років тому описав діарист, тобто купання в святих джерелах, контакт з сакральними предметами, вживання стрічок, поясів інших виробів із тканини як носіїв життєдайної енергії:

Mam nieodpatre wrażenie, że właśnie śledząc zjawisko dawnych leczniczych praktyk, pełniej możemy zrozumieć ich współczesną specyfikę - przede

7 немилосердно

8 засуджений

9 події, Ibidem, s. 314-315.

10 W.Sobol, Dyskurs życia prywatnego $w$ „Diariuszu podróżnym” Filipa Orlika (ujęcie komparatystyczne) [w:] Memuarystyka w dawnej Polsce. Redakcja Piotr Borek, Dariusz Chemperek, Anna Nowicka-Struska. Wydawnictwo Collegium Columbinum, Kraków 2016, s. 161-167.

11 MF 16748

12 M. Lubańska, Praktyki lecznicze $w$ prawosławnych monasterach $w$ Bułgarii. Perspektywa antropologii (post)sekularnej. Wydawnictwa Uniwersytetu Warszawskiego, Warszawa 2019, s. 325. 
wszystkim banalny, wydawałoby się fakt, że pewne przedmioty i miejsca $\mathrm{w}$ oczach wiernych uobecniają sacrum ${ }^{13}$.

У діаріуші років перебування в турецькій провінції Салоніки дізнаємося про найдивовижніші тогочасні хвороби та ліки на них, про лікарів добрих і не дуже сумлінних, а найголовніше - як радив сам собі гетьман із самотністю, із невизначеністю свого становища. Із тривожними думками про дружину та вісьмох дітей. Ліком стає молитва. Відразу дві або й три служби замовляє за дітей у дні їхнього народження, за здоров'я дружини Анни з роду Герциків. Орлик відвідує в Салоніках всі храми, найчастіше святого Антонія та святого Теодора, є добрим християнином, але ніде не підкреслює своєї конфесії. Вірить у силу молитви за здоров'я своїх рідних і друзів. Одне із описаних Орликом тогочасних лих сприймається нині по-сучасному «зле повітря». Саме такий евфемізм повторюється в рукописі, коли мова заходить про пандемію чуми в Салоніках, Смирні, Стамбулі. У 1724 році Орлик разом із приятелями втікає від біди з Салонік до села Галаціти. Але подальші щоденникові нотатки розповідають про спалахи епідемії, від якої помирають і в інших міста, про це пише Орлик у наступних роках діаріуша. Не знайдемо жодної згадки про якісь ліки від цього лиха. Натомість тогочасна медицина вже давала собі раду з такими захворюваннями, як «кристера», «пароксизма» чи «фебра». То власне фебра, або ж пропасниця, найбільше мучила мешканців Салонік. Нестабільний клімат міста, на який часто нарікає Орлик, сприяв таким хворобам ${ }^{14}$.

Як лікувалися мешканці Салонік? Які ліки на той час були розповсюджені? Сьогодні вони можуть і здивувати, і спонукати до рефлексій, як наприклад, пускання крові з вени: „We czwartek kazałem sobie krew puścić $\mathrm{z}$ mediany przed południem, a po obiedzie

13 Ibidem.

${ }^{14}$ P. Orlyk, Diariush podorozhnii, yakyi v imia Troitsi naisviatishoi, rozpochatyi v roku 1720 misiatsia zhovtnia dnia 10-ho. Tom III, Vydavnytstvo «Tempora», Kyiv 2013, s. 145. 
przechodziłem się nad morze"15. Знані від прадавніх часів ліки природного походження використовувалися і у XVIII столітті. Так, часник допомагає від болю голови. А звичайний хрін, який гетьман отримує в подарунок від митрополита, сприймається як панацея та запорука поправи самопочуття ${ }^{16}$. Приязнь має для Орлика першорядне значення: «мій коханий», як наголошує Орлик у діарії, отець протосингел синайський привозить йому цілюще зілля («kilkanaście korzonków chrzanu») від отця митрополита серезького, «великого мого приятеля». Приятелем стає йому і медик Даніель, який від фебри рекомендує пурганс (purgans), лаксативу та екзотичний лік "Kina Kina sive rabia» ${ }^{17}$. За кілька днів, у четвер, той же лікар вдається до нових форм допомоги, аби вивести гетьмана з важкого стану після прийняття екзотичного ліку: «18/7 we czwartek dał mi Żyd Medik laxacią dla wypędzenia z żołądka Kiny Kiny, ktora mię operowała letko, i dobrze od rana az do pierwszey godziny"18. 3 подальших нотаток може скластися враження, що Орликові, який відчув спрагу після прийняття ліку «Кіна Кіна або рабіа», принесло полегшення вино наполовину з водою, якого запрагнув випити.

В іншому випадку свіжі газети, цього разу італійські, не лише підіймають настрій, а й полегшують загальний стан, коли допікав сильний кашель («kaszel srodze trapi, y przez całą mię noc prawie przeszłą inkommodował ${ }^{19}$ tak dalece, że więcey nad półtory godziny nie mogłem spać ${ }^{20}$ ). Настрій покращується, коли отримавши від приятеля Гнесто свіжі газети (цього разу ітаійські), заглиблюється в їх читання, а потім реасумує в кількох реченнях, що діється в світі - у Франції, Іспанії, Швеції, Римі, Відні - у нотатці за 12 жовтня 1726 року.

\footnotetext{
15 Ibidem, s. 101.

16 Ibidem, s. 209.

17 Ibidem, s. 146.

18 Ibidem, s. 147.

19 Incommodo - перешкоджати

20 Ibidem, s. 207.
} 
Po południu przysłał mnie Pan Gnesto gazety drukowane Italjańskie, z których constant ${ }^{21}$, że Francja cale daleka jest od wojny, i bardziej chce kontinuować pokój i w przyjaźni stałej z Cesarzem i z Królem Hiszpańskim zostawać, aniż się faedere $^{22}$ wiązać $\mathrm{z}$ Potencjami Heretyckiemi. Cesarzowa Jej m[o]ść Ruska intra$v i t^{23} \mathrm{w}$ alians, $\mathrm{z}$ Cesarzem J[ego] $\mathrm{m}[\mathrm{o}]$ ścią Rzymskim, i traktat w Wiedniu skonkludowała przez Plenipotencjariusza ${ }^{24}$ swe[go] J[ego] m[ość] Pa[na] Ludwika Kazimierza z Łanczyna Łanczyńskie[go] Szambelana ${ }^{25}$ swe[go]. Szwecja zaś uczyniwszy alians z Cesarzem J[ego] m[o]ścią Rzymskim, i z Cesarzową Jej m[o] ścią Ruską, niedotrzymała onego, i wkroczyła in faedus ${ }^{26} \mathrm{z}$ Królem Angielskim ${ }^{27}$.

Вітальна сила еманує від найперших нотаток за жовтень 1726 року: знаходимо першу згадку про тогочасну гру як утіху приятельських зустрічей, а чи прикмету спокійного часу, в яку Орлик грає із найближчим приятелем французьким консулом, хоча й короткий час. Автор називає іï «L。Ombra» (в іншому місці - „Lombra”):28

1/20 We wtorek po Kondyi był u mnie Pan Consul Francuski, i zabawił się u mnie grą $\mathrm{L}^{\circ} \mathrm{Ombra}$ do wieczera. 2/21 we środę byłem u $\mathrm{Pa}$ [na] Consula Francuskie[go] o Kondyi i zabawiłem się u nie[go] do samej nocy na tejże samej grze $\mathbf{L}^{\circ} \mathbf{O m b r a}^{29}$.

Товариське життя, бесіди («дискурси») за появою нових лектур та гри сприяє появі нових приятелів та знайомих. Один із них французький купець і капітан Шавалер, який розповідає про вулкан Везувій, про землетрус у столиці Сицілії Палермо та інші новини ${ }^{30}$.

11/30 w piątek po obiedzie byłem u Pa[na] Consula Francuskie[go], gdzie zabawiłem się do wieczera grając w Lombra, a bez bytności mojej przychodził

\footnotetext{
21 констатую

22 вузол

23 увійшла

24 уповноважений

25 урядовець високого рангу

26 в лізі, в спілці

27 Ibidem, s. 207.

28 Ibidem, s. 206.

29 Ibidem, s. 203.

${ }^{30}$ Ibidem, s. 206.
} 
do mnie Pan Chawalier Kupiec Francuski wczora tu do portu przybyły chcąc mi oddać wizitę, ale niezastawszy mię przywitał się ze mną tamże u Pa[na] Consula Francuskie[go], gdzie słyszałem że część większa miasta Stołeczne[go] w Siciliej Palermy zapadła się z kilkanastu tysięcy ludzi. Żałosny wprawdzie casus i ruina, ale w tym kraju, czesto to bywa dla wybuchających ogniów z Wezuwiusza, i dla trzęsienia ziemi gwałtowne[go], i wielu już tam miast głównych ziemia i morze pożarły ${ }^{31}$.

Тільки в одному випадку описана фізіологічна реакція організму на ліки ${ }^{32}$, обсервація, що діється 3 тілом унаслідок лікування. Звично Орлик дуже делікатний і стриманий. Сам себе Орлик пізнає із подивом: еміграція змінила його. Так, у нотатці з 27 листопада 1726 року маємо оповідання із бароково-контрастними сильветками тогочасних лікарів, талановитого і бездарного. Обоє взялися рятувати на міру власних знань, здібностей та досвіду поштивого й шанованого в Салоніках чоловіка Хаджі Діаменди. У його голові залишилася випадкова куля, яка могла спричинити швидку смерть. Першим його лікарем був медик, нацією Грек, але досвідчений та бувалий в «cudzych Kraiach Włoskich». За його допомогою Хаджі Діаменді видужав, почав ходити і навіть був на службі Божій на святого Димитрія та на обіді у митрополита. Але згодом довідується, що до Салонік прибув на кораблі купецькому медик Француз. Обіцяючи неможливе, новоприбулий медик не слухає раціональних доказів свого опонента - лікаря-Грека (хоча «tamten Cerulik Greczyn srodze się temu opponował»). Цілковитого зцілення не сталося, а навпаки, лікар-наступник зводить Хаджі Діаменди (врятованого талановитим попередником) у могилу:

Byłem też i Ja z powinności Chrześciańskiej na tym pogrzebie, któremu assistował Metropolita z dwoma Ep[isko]pami i z całym Duchowieństwem tutejszym w Cerkwi Ś[więtego] Athanazego, po skończeniu pogrzebowych hymnów, miał kazanie, kupcy wszyscy znaczniejsi tutejsi także byli i wielu Ludzi, z których mało kogo widział niepłaczące[go] i nieżałujące[go] tego

31 Ibidem, s. 206.

32 Ibidem, s. 149. 
człowieka, który wielkiej był poczciwości, a lubo Ja z natury twardy jestem do płaczu, jednak nie mogłem się utrzymać od łez, widząc nad tym człowiekiem pospolity płacz i rzewny żal. Niech tedy requiescit in pace ${ }^{33}$.

Тут цінним видається не стільки опис подій, свідком яких Орликові судилося стати на еміграції, а процес його самопізнання. Свідоцтва автора діаріуша, як неодноразово переконуємося, переплітаються із зізнаннями. Це відбувається в якісно нових ситуаціях. Найбільш зворушливими $є$ інтимно-родинні, проникливі нотатки, як наприклад у тузі за померлим у Вроцлаві десятирічним сином. Як зі своїм болем, так і з несподіваною радістю він усамітнюється. Переживає і горе, і подарунки долі зі своїм мовчазним приятелем-сповірником, яким є власноруч писаний діаріуш. Про добру новину, народження 22 березня 1726 року третього онучати, цього разу дівчинки ${ }^{34}$, знаходимо радісний запис. Наразі гетьман дізнається про відрадну подію аж через півроку, 29 жовтня 1726 року. Повернувшись зі Служби Божої, яку він найняв у церкві святого мученика Теодора за здоров’я своєї доні Марисеньки в день ії народження, гетьман отримує листа від коханої дружини з Кракова:

...A kiedym powrócił po Nabożeństwie, właśnie jakby w półgodzinę odebrałem listy od mojej najmilszej małżonki z Krakowa przez umyślnie tu do mnie delegowane[go] człowieka urodzeniem Greka od Pana Jana Beglego, kupca także Greka w Krakowie mieszkające[go], kreditora Żony mojej, który requiru$i a c^{35}$ po mnie wypłacenia 2000 talarów, przysłał tu synowca czyli siostrzeńca swe[go], z swoim i żony mojej najmilszej listami, z których informowałem się że chwała Bogu Najwyższe[mu] cała familia ${ }^{36}$ moja zdrowa, że Córka moja najmilsza Anastazja Stenflikowa Generałowa Marty $22^{37}$ w tym roku Córkę sobie a mnie wnuczkę powiła, i już z błogosłowieństwa i miłosierdzia

33 спочиває з миром, Ibidem, s. 238.

${ }^{34}$ Правдоподібно, онука не прожила довго, бо ж у щоденнику з наступних років про неї ані слова.

35 який вимагає

${ }^{36}$ родина

3722 marca 1726 roku 
Boskie[go] dwóch mam wnuków, a trzecią wnuczkę, którzy niech na chwałę Boską szczęśliwie rosną, a nam na pociechę ${ }^{38}$.

Якщо родинні події та новини Орлик переживає наодинці, то відомість про лист від короля Станіслава до гетьмана миттєво стає знаною в Салоніках навіть без його волі. Психологічно-ментальний портрет Орлика увиразнює дискурс, знаний в культурі як savoir-vivre, як чудодійний лік. Гречність - суспільно акцептована гра - в товаристві Орлика має свої правила. Це не тільки вживання гречних слів та зворотів в окреслених ситуаціях (бесіди, звані «дискурсами»), а й реальні вчинки з наміром сприяти чи допомогти комусь у складній ситуації. Товариство Орлика в Салоніках, крім Міхала, єдиного з 8 дітей, який був 3 ним, а також мандрівників та випадкових гостей, які відвідували гетьмана, - це французький консул Бланк, митрополит, англійський попередній консул Джонс, його друг, і теперішній англійський консул, Стівенсон.

У словнику (Słownik językowego savoir-vivre'u ${ }^{39}$ ) з його 52 розділами є акцент авторки Малгожати Марціянік, що у виданні зібрано й представлено, якими словами гречності послуговуються люди останньої декади XX і першої декади XXI ст ${ }^{40}$. Із подивом констатуємо, що в рукописі чимало висловів, які не змінилися від століть і знайшли своє місце у згаданому словнику. То може бути окрема тема для аналізу, як відбулося заприязнення Орлика, котрий засвоїв науки і в єзуїтському колегіумі Вільно, і в Києво-Могилянській Академії, з французьким консулом

${ }^{38}$ P. Orlyk, Diariush podorozhnii, yakyi v imia Troitsi naisviatishoi, rozpochatyi v roku 1720 misiatsia zhovtnia dnia 10-ho. Tom III, Vydavnytstvo "Tempora», Kyiv 2013, s. 214-215.

${ }^{39}$ M. Marcjanik, Stownik językowego savoir-vivre'u. Wydawnictwa Uniwersytetu Warszawskiego, Warszawa 2017, s. 8.

40 Авторка словника Малгожата Марціянік адресує словник для студентів гуманістичних студій (полоністика, журналістика, культурознавство), де є такі предмети, як „Etykieta jezykwa”, „Etykieta w komunikacji”, „Językowy savir-vivre”, „Etyka, estetyka, etykieta językowa”( M. Marcjanik, Słownik językowego savoir-vivre’u. Wydawnictwa Uniwersytetu Warszawskiego, Warszawa 2017, s. 9). 
Бланком, який у Салоніках став його найближчим другом. Гетьман цінує високу культуру Бланка та його дружини, шліфує в їхньому товаристві знання французької, дбає, аби дружні стосунки з приятелями були міцніші за всі незгоди:

...wstąpiłem do Ojca Metropolity, którego zastałem w Cerkwi na Nabożeństwie Nieszpornym, po którym zabawiłem się z nim z półgodziny na różnych diskursach, a kiedym wyszedł od niego, dali mi znać ludzie moi, że Pan Consul Francuski bez bytności mojej przysyłał do mnie do gospody, dając znać że mię chce nawiedzić z Jej m[o]ścią Swoją, wstąpiłem tedy do nie[go] prosząc o wybaczenie i żałując że nie mogłem mieć dla absency $i^{41}$ mojej honoru przyjęcia Ich m[ości] u siebie, obiecali tedy jutro u mnie bydźt ${ }^{42}$.

Повною протилежністю до Бланка є англійський консул Стівенсон-дивак, якого гетьманові по-людськи шкода. Чому? Бо є відлюдником і безбожником:

19/8 we czwatrek w Święto Narodzenia Najświętszej Panny po południu o Kondyi, chciałem nawiedzić Pana Consula Angielskie[go], alem nie zastał nikogo, i wrota były zamknięte, gdyż Sama z Córkami chodziła za miasto na promenadę, a Sam siedział jeden jak niedwiedź zamknąwszy się w domu, dziwne[go] ten jest człowiek a prawie dzikiego humoru ${ }^{43}$.

I наступного разу Орлик застає подібну картину, але не зневіряється, а всупереч побаченому хоче зрозуміти ірраціональну поведінку, а може хворобу, щоб спробувати якось допомогти Стівенсонові:

21/10 w sobotę nic nie było ad notandum ${ }^{44}$, tylko że po długim niewidaniu się byłem u Pana Consula Angielskiego, które[go] zastałem jednego w Domu jak niedwiedzia siedzące[go], Sama zaś z Córkami odeszła była na promenadę ${ }^{45}$

41 брак

${ }^{42}$ P. Orlyk, Diariush podorozhnii, yakyi v imia Troitsi naisviatishoi, rozpochatyi v roku 1720 misiatsia zhovtnia dnia 10-ho. Tom III, Vydavnytstvo «Tempora», Kyiv 2013, s. 191.

43 Ibidem, s. 190.

44 до нотування

45 Ibidem, s. 193. 
Наполегливість гетьмана в поверненні теперішнього англійського консула до нормальності - також штрих до його шляхетності, до такої людської вдачі, яка бажає іншим добра. Така постава стає зрозумілою також і з огляду на його дружбу з попереднім англійським консулом Джонсом, з яким заприязнився відразу по прибуттю до Салонік, а наступно листувався. Тому Орлик тішиться, зустрівшись з Рубертом Міллінгом, приятелем свого приятеля Джонса:

... kiedy zabawiłem się z półtory godziny na różnych diskursach, z J[ego] $\mathrm{m}[\mathrm{o}]$ ścią Panem Consulem Francuskim, który nadszedszy do mnie insperate ${ }^{46}$ o dziesiątej godzinie przed południem, odszedł w pół do dwunastej. Nad wieczer był u mnie kupiec Angielski Pan Rubert Miling, który wczora do portu tutejsze[go] przybył z Swoim Okrętem, gdzie coroku bywa, człowiek poczciwy i wielki me[go] Przyjaciela $\mathrm{Pa}\left[\right.$ na] Jonesa przyjaciel ${ }^{47}$.

Але не тільки позитивна настанова до життя, переклади, листування, полювання, вивчення французької, лектури справляють оздоровчий вплив на самого Орлика та його оточення: „Czytanie w ciszy, dla samego siebie, wystarczy, aby stworzyć sferą zażyłości oddzielającą czytelnika od zewnętcznego świata"48. Вдумливе читання гартує волю, уміння запанувати над емоціями. Розшифрування рукопису дозволяє не погодитися з Борисом Крупницьким, який свого часу писав:

«Впертий, еластичний і гнучкий, він (Орлик. - В.С.) не мав у своїм розпорядженні лишень однієї прикмети, такої необхідної для державного мужа великого формату. Він не належав до сталевих натур, як ось Богдан Хмельницький і Мазепа, при всій еластичності останнього»99.

46 несподівано, зненацька

47 Ibidem, s.205.

${ }^{48}$ Historia życia prywatnego. Tom 3. Od renesansu do oświecenia. Pod redakcją Rogera Chartiera. Zakład Narodowy im. Ossolińskich, Wrocław, Warszawa, Kraków 2005, s. 169.

49 B. Krupnytskyi, Hetman Pylyp Orlyk (1672-1742). Ohliad yoho politychnoi diialnosty, Varshava 1937, s. 176. 
Твір одкровення, щоденник дає десятки прикладів того, що навіть у найскладнішій ситуації, як би зле не почувався, гетьман дотримується етикету, не відмовляє в допомозі. Уміє сердечно поговорити із мандрівними монахами з гори Афон, щиро почастувати, елегантно надати свою карету, єдину в Салоніках, для дружини свого приятеля французького консула Бланка та ін. Неодмінна прикмета його вдачі - це гостинність. Завжди достойно приймає гостей. Наприклад, доброго і поштивого Рафаеля Вілрояля. У 1724-му Орлик пізнав його, коли той зачарував грою відразу на двох музичних інструментах. Через два роки, в 1726-му, Вілрояль прибуває в гості до гетьмана разом зі своїм старшим братом.

26/15 we czwartek nawiedział mię Rafael Wilrojal Żyd znaczny kupiec Liworneński, mający tu wielką estimę $e^{50}$ u kupców Francuskich i u same[go] Consula Francuskie[go] owszem u wszystkich Turków i Greków, Żydzisko dość dobry i poczciwy, który przyprowadził z sobą do mnie brata swego starsze[go] rodzone[go], novissime ${ }^{51} \mathrm{z}$ Liworny przbyłe[go], dla oddania mnie wizity, których przyjąłem ea civilitate $e^{52}$, która ich osobom należała ${ }^{53}$.

Можемо говорити про різноманітні форми самопрезентації гетьмана на дорозі пізнання себе самого в умовах безвиході, яку спричинила еміграція. У 1725, 1726, 1727 роках домінує самотність як стан і як відчуття, самотність, яка стає, як у Монтеня (Michel de Montaigne), дорогою до спокійної мудрості. Нових вимірів набувають мотиви приватності, хвороби і одужання, приязні і дружби, усамітнення з лектурою, зрештою, виразніше, ніж досі окреслюється самоусвідомлення дороги, якою ішла душа мандрівника, "peregringa», яким вважає себе сам у 1727 році, після вісімнадцяти років еміграціі. У початковій частині діарія

\footnotetext{
50 пошана

${ }^{51}$ недавно

52 зичливо

${ }^{53}$ P. Orlyk, Diariush podorozhnii, yakyi $v$ imia Troitsi naisviatishoi, rozpochatyi v roku 1720 misiatsia zhovtnia dnia 10-ho. Tom III, Vydavnytstvo «Tempora», Kyiv 2013, s. 196.
} 
(1720-1723 роки) від переслідування російського шпигуна Ягужинського рятує Орлика родич з Ополя барон Кароль Орлик, одного з ним гербу. Швагра Григорія Герцика у Варшаві арештували. Орлик арешту уникнув, заслання - ні. У частині діарія, написаній у турецькій провінції, в Салоніках гетьман рятує сам себе, свою справу, і наскільки може - свою родину. Причому мало допомогли його численні листи і шифрами, і різними мовами - латиною, французькою, польською - до сильних світу, в т.ч. й до папи Бенедикта XIII та королів. Тут до більш ретельних студій маємо психологію макроіндивідуального самовияву і саморятунку. Сам собі стає опертям, чудодійним і реальним водночас.

\section{References}

Averyntsev S., Chudo [w:] S.S.Averyntsev. Sofiia- Lohos. Slovnyk. Dukh i litera, Kyiv 1999.

Chomik P., Kult ikon Matki Bożej w Wielkim Księstwie Litewskim w XVI-XVIII wieku, Wydawnictwo Uniwersytetu w Białymstoku, Białystok 2003.

Historia życia prywatnego. Tom 3. Od renesansu do oświecenia. Pod redakcją Rogera Chartiera, Zakład Narodowy im. Ossolińskich, Wrocław, Warszawa, Kraków 2005.

Krupnytskyi B., Hetman Pylyp Orlyk (1672-1742). Ohliad yoho politychnoi diialnosty, Varshava, 1937.

Księga Cudów przed ikona Matki Boskiej Waśkowskiej dokonanych. Do druku przygotował i wstępem opatrzył Antoni Mironowicz, Wydawnictwo Uniwersytetu w Białymstoku, Białystok 2012.

Księga Cudów przed ikoną Matki Bożej w Starym Korninie dokonanych dokonanych. Do druku przygotował i wstępem opatrzył Antoni Mironowicz, Wydawnictwo Uniwersytetu w Białymstoku, Białystok 1997.

Kyievo-Pecherskyi pateryk. Vydannia druhe, vypravlene. Vydavnytstvo «Svichado», Lviv 2004.

Lubańska M., Praktyki lecznicze w prawosławnych monasterach $w$ Bułgarii. Perspektywa antropologii (post)sekularnej. Wydawnictwa Uniwersytetu Warszawskiego, Warszawa 2019.

Marcjanik M., Słownik językowego savoir-vivreu. Wydawnictwa Uniwersytetu Warszawskiego, Warszawa. 
Napiórkowski M., Od teoretyzowania na temat praktyk do praktykowania teorii [w:] Antropologia pamięci. Zagadnienia i wybór tekstów. Wstęp i redakcja Paweł Majewski, Marcin Napiórkowski, Wydawnictwa Uniwersytetu Warszawskiego, Warszawa 2018, s. 7-37.

Orlyk P., Diariush podorozhnii, yakyi v imia Troitsi naisviatishoi, rozpochatyi $v$ roku 1720 misiatsia zhovtnia dnia 10-ho. Tom III, Vydavnytstvo «Tempora», Kyiv 2013.

Pro stipku chudovnu naisviatishoi Marii divy na Hori Pochaivskii ta yii davnist. Pereklad V.Sobol [w:] Skarbnytsia potrebna y pozhytochna. Ukrainski monastyrski litopysy, zhytiia, povchannia chentsiam, chuda ta inshe. Uporiadkuvannia, vstupna stattia ta komentari Valeriia Shevchuka, Vydavnytstvo «Lybid», Kyiv 2012, s. 414-426.

Shevchuk V., Pro istoryko-literaturni pamiatky, shcho tvorylysia $v$ ukrainskykh monastyriakh [w:] Skarbnytsia potrebna y pozhytochna. Ukrainski monastyrski litopysy, zhytiia, povchannia chentsiam, chuda ta inshe. Uporiadkuvannia, vstupna stattia ta komentari Valeriia Shevchuka, Vydavnytstvo «Lybid», Kyiv 2012.

Skarbnytsia potrebna y pozhytochna. Ukrainski monastyrski litopysy, zhytiia, povchannia chentsiam, chuda ta inshe. Uporiadkuvannia, vstupna stattia ta komentari Valeriia Shevchuka, Vydavnytstvo «Lybid», Kyiv 2012.

Sobol W., Dyskurs życia prywatnego w „Diariuszu podróżnym” Filipa Orlika (ujęcie komparatystyczne) [w:] Memuarystyka w dawnej Polsce. Redakcja Piotr Borek, Dariusz Chemperek, Anna Nowicka-Struska. Wydawnictwo Collegium Columbinum, Kraków 2016, s. 161-167. 


\title{
Yaroslav Myshanych
}

National Academy of Sciences of Ukraine (Ukraine)

ORCID: 0000-0003-0775-5951

\section{Утвердження просвітницької естетики у щоденнику Петра Апостола}

\section{The establishment of the Enlightenment Aesthetics in the Diary of Peter the Apostle}

\begin{abstract}
:
The diary of Petro Apostol belongs to great samples of documentary prose of the beginning of the 18th century. The document indicates an expressive influence of the European ideological and cultural trend of the Enlightenment, which found its reflection in the language, figurative system and problems. The author wrote his diary for more than two years - from May 1725 to August 1727. There are several motifs in the diary, against the background and in the interweaving of which the historical era of Ukraine of that time is visible. First of all, it is told about the family of the Apostols and their life in the Myrgorod regiment. The system of images created by the author is interesting - here his parents, peasants, Cossacks, serfs, Cossacks foremen, Russian nobles, merchants, princes, tsars, foreigners, friends of the author. The author's attitude to his heroes is characteristic of enlighteners. It is rationalistic, that is, each mentioned person in society performs his function regardless of which class he belongs to. Particular interest in a wide range of problems that the author writes about in his notes - he is interested in family, agriculture, relations between people, legal issues, the problem of serfdom, poverty, personal relations, he talks about books and newspapers, about friends, about his father, about Prince Menshikov and his service, talks about entertainment and leisure, about dances and receptions, talks about clothes and everyday life, about gifts for the family, about his wife, about baptism and the birth of a child. The author does these problems esthetic in his notes, puts them into literary practice.
\end{abstract}

Keywords: rationalism, enlightenment, policy, esthetics, context, perspective. 


\section{Мета статті}

Проаналізувати вплив європейського Просвітництва на українську щоденникову літературу. Вказати на характерні риси, котрі з'явилися ущоденнику Петра Апостола, проаналізувати його жанр, стиль і проблематику, вказати на контекст, у якому він був створений.

Щоденниковий жанр або, за словами В.Шевчука, «стисле літописання», набуло в Україні значного поширення переважно у другій половині XVII - XVIII ст. і стало помітним явищем так званої документальної літератури.

Загалом щоденникова література досліджувалася у наукових працях Олександра Галича, Миколи Корпанюка, Дмитра Затонського, Валентини Соболь, Олега Єгорова, Ольги Зінченко, Петра Білоуса, Ірини Сирко, Наталії Стахнюк, Світлани Ігнатьєвої, Олени Отземко, Ольги Матвеєвої.

Здебільшого дослідники щоденників і діаріушів для своїх студій обирають джерелознавчий дискурс (Отземко Олена), жанрову специфіку, походження жанру, його різновиди, типологію (О. Матвеєва, Н. Стахнюк, І. Сирко), досліджують жанр в контексті традицій (В. Соболь) і в контексті епохи (О.Зінченко). Велику цікавість становлять комплексні наукові дослідження щоденників українських письменників XX ст. О. Галича та студії над мемуарно-літописними творами XVI - XVIII ст. М. Корпанюка.

Початок XVIII ст. в Європі був позначений швидким поширенням і розвитком ідейно-культурної течії Просвітництва. Дослідженням впливів просвітництва на українську літературу, зокрема на щоденникарство, початку XVIII ст. дотепер належної уваги не приділялося. Просвітницька тематика набула широкої популярності у вивченні значно пізнішого періоду - творчості Григорія Сковороди.

Особливе зацікавлення, на нашу думку, становлять діаріуші першої третини XVIII ст., написані представниками шляхетських козацьких родів, оскільки ці люди були свідками важливих історичних подій, а відтак були причетними до них. До таких належить, зокрема, щоденник Петра Апостола. Оригінал 
твору є франкомовним. Перший переклад щоденника Петра Апостола 3 французької мови на російську було виконано Олександром Лазаревським і надруковано в журналі «Киевская старина» в 1895 році1. Писати щоденник Петро Апостол почав ще будучи в Україні, тоді продовжив його у російській столиці. Чи це робилося з власної волі, чи на замовлення - достеменно невідомо. Валерій Шевчук вважає, що праця молодшого Апостола поєднує в собі риси діаріуша індивідуального та офіційного, тобто такого, що виконувався за дорученням когось зі старших, але водночас містить багато особистих, родинно-побутових моментів. Текст пам'ятки охоплює період часу трохи більше, ніж два роки - з травня 1725 р. по серпень 1727 р.

\section{Про мову}

Мова щоденника - французька. Чому автор обрав одну із сучасних йому європейських мов замість широковживаної в той час латини чи, зрештою, не послуговувався рідною? Можемо запропонувати дві версіі. Перша найімовірніша - світоглядна. Як відомо, Петро Апостол отримав освіту за місцем проживання - у Москві, при дворі князя Олександра Меншикова, куди його забрали з України заручником ще в дитинстві. У ті часи цар Петро I був відомий своїми реформами, дбав про освіту дворянських (і не тільки) дітей і запрошувати вчителів 3-за кордону було звичайною практикою.

Автор «Історії України та українських козаків», австрієць Йоганн-Християн Енгель згадував, що молодий Апостол досить вільно послуговувався в житті щонайменше чотирма європейськими мовами - французькою, німецькою й італійською, польською, знав також латинуㄹ. Це зрозуміло і з тексту його щоденника.

1 A. L. [Lazarevskyi O.] Dnevnyk Petra Danylovycha Apostola (mai 1725 h. - mai 1727 h.), „Kyevskaia staryna”, 1895, T. 50, №7/8, Otd. 2, s. 100-155.

2 Ukrainska derzhava druhoi polovyny XVII - XVIII st.: polityka, suspilstvo, kultura, Kyiv 2014, s. 177. 
Вірогідно, що через вчителів йому передалася цікавість до просвітницьких ідей, котрі набули широкого поширення в Європі на початку XVIII ст. Цим пояснюється його зацікавлення європейською літературою і пресою, які йому привозили на замовлення і на які він витрачав великі, як на той час, гроші. Зрозуміло, що молода людина тягнулася до знань і продовжувала здобувати їх шляхом самоосвіти - через книжки, словники та пресу з Західної Європи.

Доступна література національними мовами могла спонукати молодого сина Миргородського полковника Данила Апостола викласти свої думки однією з європейських мов, а саме французькою, котра на той час витісняла латину в науковому світі й побутувала в міжособистісному спілкуванні освічених людей. Зрештою, походження й соціальний стан Петра Апостола так само посприяли його мовним уподобанням.

Друга версія - конфіденційно-криптологічна - не суперечить першій, лише доповнює іiі. Автор щоденника не бажав, щоб його твір читали сторонні. Можемо припустити, що французькою мовою в Російській імперії на той час володіло не так багато людей, навіть з високим соціальним статусом. Так, покровитель Петра Апостола - князь Олександр Меншиков - не вмів ні читати, ні писати, через що потребував грамотного помічника ${ }^{3}$. Можемо зробити попередній висновок - свій щоденник Петро Апостол писав для родинного кола чи для себе особисто. Це питання суперечливе, бо, з одного боку, щоденник міг бути призначений для однієї особи, але можливо й протилежне бажання автора зацікавити більшу кількість читачів через множинність проблем, поставлених у ньому4 і таким чином зробити крок у бік популярної літератури.

\footnotetext{
${ }^{3}$ N. Y. Pavlenko, Aleksandr Danylovych Menshykov, «Nauka», Moskva 1983, s. 198. ${ }^{4}$ S. V. Turaev, Spornye voprosy lyteratury Prosveshchenyia [w:] Problemy Prosveshchenyia v myrovoi lyterature, «Nauka», Moskva 1970, s. 16.
} 


\section{Структура щоденника}

Пам'ятку можна умовно розділити на дві половини. Перша iï частина була написана в період життя автора в Україні, на території Миргородського полку тодішньої Гетьманщини. У другій частині йдеться про переїзд до імперської російської столиці Петербурга та перебування в ньому.

Текст щоденника складається з розміщених у хронологічному порядку записів про поточні події і факти. Кожна нотатка може сприйматися читачем як окрема оповідь на певну тему, яка має власний сюжет і власних героїв. Зауважимо, що художнє оформлення оповідей $є$ більш ніж скромне, очевидно, автор з певних причин ставив собі за мету розповісти більше, не користуючись великою кількістю виражальних засобів. Це не суперечить тогочасному поетичному канону, що застосовувався для історичних творів. Навпаки, на переконання Феофана Прокоповича, історичний твір повинен відповідати трьом критеріям: стислості, ясності і правдоподібності 5 , а сам історик повинен бути обачним і скупим щодо підбору слів для своєї праці, щоб не провокувати недовіру до неї захопленістю до охудожнення твору. Основа щоденникарства - простота, доступність і правдивість. Літописець мусить казати правду і лише правду. Записи Петра Апостола цілком відповідають цим вимогам. Виникає закономірне питання - до якого типу творів належить щоденник Петра Апостола - до історичних чи до літературних? На нашу думку, в конкретному випадку можемо говорити про історизм літературного твору та літературність історичного - однаковою мірою. I форма і зміст пам'ятки доводять, що цей твір належить історикам, але його образна система, тематична строкатість і контекстуальність можуть досліджуватися методами літературознавства, а знання історії й філософії виконають допоміжну роль.

${ }^{5}$ F. Prokopovych, O poetycheskom yskusstve [w:] F. Prokopovych, Sochynenyia, Moskva-Lenynhrad 1961, s. 401-402. 


\section{Контекстуальність}

Для адекватного прочитання й розуміння щоденникових записів Петра Апостола важливого значення набуває розуміння контексту історичної доби та культурної ситуації, в яких знаходився автор щоденника.

Конкретно-історична дійсність, відображена у творі, сприймається як його максимальний (віддалений) контекст i реалізує зв'язок автора і дійсності читача, внаслідок чого забезпечується історична безперервність людського досвіду взагалі і досвіду художнього зокрема6

У нашому випадку необхідно зрозуміти умови й обставини життя в Україні першої третини XVIII ст., в яких знаходився автор щоденника і з яких він брав матеріали для своїх записів і котрі мали вплив на його світосприйняття, на нього особисто та на його твір. Це можуть бути й історичні обставини, що склалися на території України після поразки шведів під Полтавою, і пов'язана $з$ цим фактична ліквідація інституту гетьманства та залишків незалежності Української козацької держави. Вплинула на автора й політична ситуація, що склалася в столиці імперії Петербурзі після смерті Петра I, і спроби Миргородського полковника Данила Апостола відновити гетьманський уряд вже за сприяння нового царя. Культурний стан тогочасних вищих соціальних кіл, зокрема можливість вивчати іноземну літературу, спілкуватися з іноземцями, читати їхню пресу, відвідувати театральні вистави, церковні служби, бали, прийоми - також варто взяти до уваги. Важливе суспільне становище самого Петра Апостола в Миргородському полку, де він задіяний як господарник і суддя. Дуже помітний вплив батька, який потребує синової допомоги у своїх державницьких справах. Добра освіта Петра Апостола посприяла його широкому світогляду, інтересам і тому багатству тем, про які він оповідає у щоденнику. Помітне

${ }^{6}$ ULE, «Ukrainska radianska entsyklopediia» im. M. P. Bazhana, Kyiv 1990, t. 2, s. 557-558. 
пожвавлення міждержавних стосунків з європейськими країнами на початку XVIII ст. відкрило перед ним нові можливості для спілкування й самоосвіти, що опукло відображено в творі.

Зауважимо, що процес існування твору в літературі має дві сторони - його написання і його прочитання, причому важливим $\epsilon$ саме прочитання в контексті. Мусимо визнати, що значно більша частина інформації щоденника міститься у контексті. Для повноцінного й адекватного сприйняття щоденникових записів цю двоплановість треба враховувати, пам'ятаючи, що літописи, діарії писалися «для пам'яті» як джерела інформації для обізнаного читача, котрий, знаючи й іншу інформацію, одержував можливість розгортати власну сюжетну оповідь про конкретні події та постаті.

\section{Стиль і жанр щоденника}

Якщо спиратися на класифікацію щоденників О.Г.Єгорова7, то запропонований твір за стилем можна віднести до типу інформативно-розповідних щоденників. Учений пропонує характеризувати щоденник за змістовим принципом: у нашому випадку твір має риси всіх чотирьох пропонованих ним жанрових типів: родинно-побутового, подорожнього, суспільнополітичного і службового.

Якщо звернутися до «Літературознавчої енциклопедії» ${ }^{8}$, можемо знайти такі жанрові ознаки щоденника: періодичність, регулярне ведення записів, зв'язок записів із поточними, а не давно минулими подіями, спонтанний характер записів (відсутність авторської оцінки подій), літературна необробленість записів, безадресність чи невизначеність адресата щоденника, інтимний, а тому щирий і чесний характер записів.

${ }^{7}$ O. H. Ehorov, Russkyi lyteraturnyi dnevnyk XIX veka: ystoryia y teoryia zhanra: yssled., Nauka, Moskva Flynta 2003.

${ }^{8}$ Literaturoznavcha entsyklopediia: u 2 t., VTs «Akademiia», Kyiv 2007, T. 2 / avt.-uklad. Yu. I. Kovaliv, s. 592-593. 
Лаконічність стилю, лапідарність висловлювань, за словами Д.Чижевського, можуть свідчити про «любов до простоти», «нахили до ясних, за певними приписами вибудуваних рамок», «прагнення до прозорої ясності думки», «прагнення дати найточніший вислів» у автора щоденника9. Йому властиві «ясність», «простота», «спокій», «закінченість у собі», «сконцентрованість». Літературний стиль показної простоти і ясності, за словами вченого, міг вживатися в будь-яку добу і в будь-якій європейській літературі, тож немає нічого дивного, що він проявив себе в Україні на початку XVIII ст. в епоху бароко.

\section{Вплив епохи на щоденник Петра Апостола}

Однією з найцікавіших особливостей пам'ятки є їі проблематика, точніше - iї строкатість і близькість до повсякденного життя. Розмаїття піднятих автором тем і $€$ основним аргументом на користь впливу доби Просвітництва, котра тривала в Західній Європі близько ста років - від Джона Локка (90-ті pp. XVII ст.) до Іммануїла Канта (90-ті pp. XVIII ст.) ${ }^{10}$, а відтак знайшла свій відгук і в Російській імперії.

Важливою особливістю літературного твору епохи Просвітництва $є$ демократизація його героя. Герой перестає бути винятковим і володіти унікальними можливостями, на відміну від, скажімо, літописного героя доби бароко. Він не займає вищі щаблі в соціальній ієрархії. Він $є$ просто центральною діючою особою твору, з якою читач легко може себе ідентифікувати й поставити на її місце.

Художній дискурс щоденника полягає у новизні проблем, які ставить перед собою автор. Це - актуальні на той час ідеї, нові образи, пошуки друзів, теми кохання, відпочинку,

\footnotetext{
${ }^{9}$ D. Chyzhevskyi, Istoriia Ukrainskoi literatury, Femina, Ternopil 1994, s. 28-29. 10 S. V. Turaev, Spornye voprosy lyteratury Prosveshchenyia [w:] Problemy Prosveshchenyia v myrovoi lyterature, «Nauka», Moskva 1970, s. 14.
} 
естетизація побуту шляхетства, політичних питань, балів, хрестин, народження дитини тощо.

3 прочитаного тексту щоденника бачимо, що до кола авторських інтересів потрапляє багато звичайних повсякденних питань: господарська діяльність, юридична практика, спілкування й розваги; він не втрачає нагоди чогось навчатися й прочитати книжку чи газету, відвідати театральну виставу чи церковну службу. Його цікавлять прості люди, їхні справи: він знається на сільському господарстві, має власну улюблену справу бджолярство - і докладно кілька разів у щоденнику розповідає про неї.

Якщо подивитися на жанрово подібні твори тієї доби, то найближчим до щоденника Петра Апостола за стилем є діаріуш Миколи Ханенка («Діяріуш або журнал, тобто щоденна записка оказій та церемоній, що трапляються при дворі ясновельможного його милості пана Іоана Скоропадського, військ пресвітлої його імператорської величності Запорозьких обох боків Дніпра гетьмана»), він дуже докладний і об’ємний, але, на жаль, охоплює замало часу - лише трохи більше половини 1722 року і не має такої широкої проблематики. Центральний герой у діаріуші Ханенка виражений слабко.

Записки канцеляристів Пилипа Борзаківського і Павла Ладинського (1722 - 1733 рр.) є, фактично, уривками зі щоденника Гетьманської канцелярії і їх проблематика обмежена рамками діяльності цієї установи, тому виклад матеріалу нагадує службові документи. Можемо зробити висновок, що Петро Апостол дозволив собі дивитися на життя значно ширше за багатьох сучасників, сприймати його таким, яким воно $є$ насправді й не обмежуватися якоюсь однією темою чи проблемою, становими традиціями. Він волів писати про те, що помічав, що його цікавило чи викликало якісь почуття. Тому його щоденник наближає нас до тогочасного різнобічного життя, дає виняткову можливість поглянути на нього зблизька.

Цікавою є система образів, створена Петром Апостолом, тут і образи простих селян, козаків, кріпаків, козацької 
старшини, і російського дворянства, і купців, князів, царів, іноземців, друзів самого автора. Головних образів у щоденнику кілька, це - сам автор, його батько, мати, брат і князь Олександр Меншиков. Особливу пізнавальну роль виконує образ Петрової матері - розумної, діяльної, практичної господині, української шляхтянки, берегині родини.

У добу Просвітництва (кінець XVII - XVIII ст.) відбувався «процес ускладнення самої «архітектури» художньої думки, наділення їі новими функціями, способами репрезентації і розширенням самого «семантичного поля» художнього тексту на шляхах інтеграції [...] художньої думки в просторі духовної культури. А це, певна річ, потребувало особливого реципієнта, який міг би бути інтегрований у процес відкриття/конструювання смислу, іноді навіть на рівні банальних побутових повсякденних відносин» ${ }^{11}$. Отже, якщо письменник володів мовою й стилем, то, 3 другого боку, вже повинен був знайтися читач, підготовлений до належного сприйняття такого тексту з усіма його художніми, естетичними й філософськими особливостями, читач, який розуміє обставини, за яких твір було написано і навіщо написано.

Показовим є ставлення Петра Апостола до дійсності, в якій йому довелося жити. 3 одного боку, він - лояльний до російського правління представник козацької старшини. 3 іншого - старанний помічник Данила Апостола у його справах і представник своєї нації, що турбується про долю Гетьманщини й робить усе від нього залежне для відновлення гетьманського уряду. Він змушений жити у чужому й навіть ворожому для себе середовищі, поводити себе як типовий російський дворянин і - водночас - працювати на користь своєї батьківщини. Така «двоїстітсь» поведінки й світогляду цілком може бути ознакою діяча доби Просвітництва і Бароко. Характерною рисою красного письменства доби Просвітництва,

${ }^{11}$ I. V. Limborskyi, «Ihry rozumu» v literaturi Prosvitnytstva ta yikhnia dolia za doby hlobalizatsii [w:] I. V. Limborskyi, Mahisterium. Literaturoznavchi studii, 2012, Vyp. 48, s. 95. 
висловлюючись філософськими категоріями, стала «естетизація об'єктивної реальності» й «упорядкування елементів суспільного життя окремою свідомістю крізь призму мистецтва», а також «зростаюча автономія середовища власного естетичного»12, що дало можливість Петру Апостолу підняти у своєму щоденнику багато нових проблем, котрі стали наслідком його спостережень над повсякденним життям.

Коло проблем, про які пише автор щоденника, надзвичайно широке, тому згадаємо ті з них, які роблять щоденник по-своєму винятковим. Із нотаток першої половини щоденника бачимо, що Петро Апостол є досить прагматичною молодою людиною, яка робить все з погляду доцільності й вигоди. Йому не притаманні бездумні вчинки. Вигода всієї родини становить його особистий інтерес, бо він є одним із спадкоємців дуже багатого роду, чудово розуміє, яка відповідальність лежить на ньому і яка спадщина очікує на нього в майбутньому, тому дбає про українські національні та родинні справи щиро й відповідально. У сім’ї Апостолів відчутний культ жінки-матері, яка за відсутності вдома чоловіка керує величезним господарством, у чому ӥй допомагають діти, вона ж розпоряджається сімейними фінансами. Петро Апостол кілька разів згадує в своїх записах про матір, говорить про неї з відчутною повагою та пієтетом. Цілком ймовірно, що за іiі дорученням він займається описом їхього господарства, худоби й вартісних речей. Із непідробною цікавістю пише автор про своє захоплення бджільництвом, не оминає увагою й інші сфери сільського господарства. Старанно занотовує кількість худоби на пасовищах, пише про стихійні лиха та їхні наслідки, як це бачимо в літописах інших авторів. Помітними в його записах є проблеми бідності, кріпацтва, торгівлі людьми, соціальної несправедливості, викликані як колоніальним становищем Гетьманщини під владою Москви,

12 A. H. Vorotylyn, Estetyzatsyia subektyvnoi realnosty $v$ fylosofyy postmoderna [w:] Vestn. Sev. (Arktych.) feder. un-ta., Ser.: Humanyt. y sots. nauky., 2016, № 6, s. 75 . 
так і старшинсько-магнатським господарюванням української шляхти. Петра Апостола цікавлять стосунки між людьми - він допомагає полковому судді вирішувати господарські й особисті суперечки, інколи робить це сам, намагаючись бути справедливим і неупередженим.

Спілкування 3 колоніальною адміністрацією і лояльне ставлення до російських урядовців з Малоросійської Колегії дають розуміння того, що з'явилася проблема денаціоналізації української еліти, започаткованої московськими царями. Петро Апостол вимушений демонструвати свою промосковську позицію, бо від цього залежить успіх справи його батька, котру той почав після смерті гетьмана Полуботка у далекому Петербурзі.

Просвітницька культурна течія в умовах імперії набувала своєрідних форм, які, у конкретному випадку, можемо звести до форми просвітницького прагматизму, котрий, з одного боку, був нав'язаний освіченим верствам Гетьманщини згори, а 3 іншого - охоче був прийнятий ними заради власного збагачення й комфортного життя. Відмова від політичного життя, зосередженість на господарських справах, на торгівлі й економічних питаннях не завжди подобалися тогочасній українській інтелігенції. Критику прагматизму й застереження від надмірного збагачення знаходимо в драмі «Милость Божія», присвяченій Данилу Апостолу з приводу відновлення ним гетьманства. Анонімний автор устами Богдана Хмельницького застерігає:

Напослідок глаголю: самі не купчуйте:

Лука, стрілки, мушкета і шаблі пильнуйте!

Куплями-бо обв’язан житейськими воїн,

Імені сего весьма таков не достоїн.

I дітей своїх, скоро отправлять науки,

До сей же обучайте козацької штуки ${ }^{13}$.

${ }^{13}$ Mylost Bozhiia [w:] Ukrainska literatura XVIII st., "Naukova dumka», Kyiv 1983, s. 319-320. 
Щоденник промовисто ілюструє цей процес - політичними справами займається представник старшого покоління Данило Апостол, але й він потрапляє у пастку, з якої зміг вибратися лише ціною поневолення власного сина, для котрого політика була вже не на першому місці, хоча він розповідає досить багато і про неї. У час написання щоденника його цікавить те життя, що його оточує, він живе й розважається у царській столиці разом з такими як сам, молодими інородцями-заручниками, за що йому зрідка перепадає від батька. Знаходить друзів і серед ровесників з російського дворянства, про яких неодноразово згадує. Імперська ідеологія в той час старанно прищеплювалася молодим представникам національних еліт, для чого їх викликали до столиці й брали на службу до високопоставлених осіб чи державних установ. Цікаво, що молодий українець не втрачає духу, перебуваючи, фактично, в полоні, у «золотій клітці», де кожен день міг завершитися для нього або ув'язненням, або засланням. Його прагнення до розширення світогляду через контакти з друзями іноземцями значно сильніше за страх ув'язнення, а за його спиною відчувається потужна підтримка рідних і друзів з батьківщини. Син допомагає батькові, бо не може інакше, але поза тим його цікавлять книжки, газети, бали, прийоми, власний одяг, перуки, подарунки родині - він живе як типовий представник тогочасної «золотої молоді», набирається столичного полиску. 3 іншого боку - батько допомагає синові зберегти свою ідентичність, не розчинитися й не стати космополітом в імператорській столиці. Інколи авторові щоденника бракує засобів на деякі потреби і він звертається за допомогою до батька, але завжди старанно записує, куди й на що потратив гроші. Його прагматизм не показний, але $є$ частиною життєвої філософії, закладеної батьками й вихователями. Петро Апостол пам'ятає, хто він і звідки приїхав.

Не останнє місце у щоденнику займає проблема родини. Петро Апостол пише, що має дружину, яка приїжджає до нього з України, довідавшись, що його залишають у Петербурзі замість батька. Тут вони живуть тривалий час, у них народжується 
дитина. Зрозуміло, що при ближчому розгляді щоденникових текстів початку XVIII ст. можна відшукати більше літературного матеріалу, знайти більше проблем, на які їні автори звернули увагу, глибше й повніше дослідити їхню проблематику в контексті доби. Загалом, вивчення мемуарної літератури тієї епохи далеке від завершення й чекає на своїх перекладачів і дослідників. Європейська ідейно-культурна течія Просвітництва дісталася теренів України й знайшла свій відбиток у творі Петра Апостола. 3'явилися нові теми, нова проблематика й нові образи, які поступово почали проникати в красне письменство. Важливого значення набуває контекст, у якому написано твір. Процес проникнення просвітницьких ідей та впровадження просвітницької естетики розвивався поступово, був довготривалим і потребує подальших зусиль дослідників.

Проаналізований щоденник $є$ цінною документальною пам'яткою своєї доби, своєрідним зразком стилю просвітницького прагматизму, він розкриває перед нами багато цікавих нових граней тогочасного життя, вивчення його художньо-стильових особливостей потрібне з огляду на краще розуміння мислення освіченого представника козацької старшини, його поглядів на світ, на повсякденне життя, на Гетьманщину, на складні історично-суспільні процеси, що відбувалися в Україні й за iї межами на початку XVIII ст.

\section{References}

A. L. [Lazarevskyi O.] Dnevnik Petra Danilovicha Apostola (mai 1725 h. - mai 1727 h.), „Kyevskaia starina”, 1895, t. 50, №7/8, Otd. 2.

Chyzhevskyi D., Istoriia Ukrainskoi literatury, Femina, Ternopil 1994.

Ehorov O. H., Russkyi lyteraturnyi dnevnyk XIX veka: ystoryia y teoryia zhanra: yssled. Nauka, Moskva-Flynta 2003.

Halych O. A., U vymirakh non fiction. Shchodennyky ukrainskykh pysmennykiv XX st, Luhansk 2008.

Halych O. A., Dokumentalna literatura ta hlobalizatsiini protsesy u sviti, Luhansk 2013.

Korpaniuk M., Slovo. Khrest. Shablia, Kyiv 2005. 
Limborskyi I. V., «Ihry rozumu» $v$ literaturi Prosvitnytstva ta yikhnia dolia za doby hlobalizatsii [w:] I. V. Limborskyi, Mahisterium, Literaturoznavchi studii, 2012, Vyp. 48.

Literaturoznavcha entsyklopediia: u 2 t. , VTs «Akademiia», Kyiv 2007. t. 2 / avt.-uklad. Yu. I. Kovaliv.

Mali ukrainski diiarii XVII - XVIII stolit, Uporiadkuvannia ta peredmova Valeriia Shevchuka, Kyiv 2015.

Mylost Bozhiia [w:] Ukrainska literatura XVIII st., «Naukova dumka», Kyiv 1983.

Pavlenko N. Y., Aleksandr Danylovych Menshykov, «Nauka», Moskva 1983.

Prokopovych F., O poetycheskom yskusstve [w:] Feofan Prokopovych, Sochineniya, Moskva-Lenynhrad 1961.

Turaev S. V., Spornye voprosy literatury Prosveshchenyia [w:] Problemy Prosveshchenyia v myrovoi literature, "Nauka», Moskva 1970.

Ukrainska derzhava druhoi polovyny XVII - XVIII st.: polityka, suspilstvo, kultura, Kyiv 2014.

ULE, «Ukrainska radianska entsyklopediia» im. M. P. Bazhana, Kyiv 1990, t. 2.

Vorotylyn A. H., Estetyzatsyia subektyvnoi realnosty $v$ fylosofyy postmoderna [w:] Vestn. Sev. (Arktych.) feder. un-ta, Ser.: Humanyt. y sots. nauky, 2016, № 6.

Zinchenko O. Z., «Domashnii protokol» 1717 - 1767 rr. heneralnoho pidskarbiia Yakova Markovycha v konteksti ukrainskoho shchodennykarstva XVIII st. Tekst dysertatsii na zdobuttia naukovoho stupenia kandydata filolohichnykh nauk Ukrainska derzhava druhoi polovyny XVII - XVIII st.: polityka, suspilstvo, kultura, Kyiv 2014. 
III. Ego-materiały wobec wyzwań współczesności 


\section{Terasa Chynczewska-Hennel}

University of Białystok (Poland)

ORCID: 0000-9847-4540

\section{Fragment Dziennika Nepalskiego}

\section{The Fragment of Nepal Diary}

\section{Abstract:}

In Diary, the author describes a journey through a mysterious land, the Lo Kingdom in Upper Mustang, in northern Nepal. She compares her impressions to observations of the heroes of James Hilton's famous book "Lost Horizon". The fascination with the legendary land, the mythical Šambhai (Shangri La) has a huge impact to this day and attracts many travellers to visit the former Kingdom. Hiking the Himalayan trails from Kagbeni to Syanboche to the capital of Lo Manthanang brings many different reflections to everyone. Six hundred years of tradition and modern history overlap there and interact with each other. From 2008, the Kingdom of Lo is no longer formally established. Nepal is a Republic along with the Northern Mustang.

Keywords: Nepal, the Kingdom of Lo, James Hilton “Lost Horizon”, Upper Mustang, Lo Manthang.

\section{Nepal, koniec października 2015 roku. Pięć miesięcy po trzęsieniu ziemi. ${ }^{1}$}

Wreszcie zobaczę tę tajemnicza krainę, o której czytałam w przewodnikach, w relacjach podróżników, w powieściach. Tajemnicze Królestwo - Lo, Mustang, było krainą niemalże legendarną. Dawne królestwo zajmuje obszar jakże mniejszy od rozległego Tybetu,

\footnotetext{
${ }^{1}$ Poniższy tekst jest fragmentem książki Dziennik Nepalski przygotowywanej do druku.
} 
chroniony pasmem najwyższych gór świata na południu i Wyżyną Tybetańską od północy, ${ }^{2}$

Miejsce to żyło w mojej wyobraźni razem z mitami, które mieszały się z historią tej ukrytej do początków lat dziewięćdziesiątych $\mathrm{XX}$ wieku przed turystami krainy. Stawali mi przed oczyma bohaterowie z powieści Jamesa Hiltona $z$ „Zaginionego horyzontu”3. Swoją droga Hilton czerpał wiedzę o Tybecie z wielu źródeł. Korzystał, jak uważają badacze między innymi z relacji misjonarzy jezuitów do Tybetu w XVII i XVIII wieku, zwłaszcza z opisów ojca Ippolita Desideri, który opanował język tybetański, dzięki czemu mógł wieść dysputy z lamami.

Autora "Zaginionego horyzontu" zafascynował mit o Śambhali, legendarnej krainie, znajdującej się gdzieś na północy, pełnej szczęśliwości, harmonii, skąd miała się wywodzić „świetlista istota” Bodhisattwa Majtreja, po osiągnięciu wyzwolenia wszystkich istot. To właśnie w tej krainie, w scenerii mitycznej Śambhali, która w powieści zmieniała nazwę na Szangri - La, pośród najwyższych gór, Hilton umieścił fabułę swej książki. Tam, na zboczach góry Krakal, czyli Błękitnym Księżycu znaleźli się po katastrofie samolotu bohaterowie książki. Jak zdaje się, wszystkie utopie obiecujące nieskończoną szczęśliwość, tu w klasztorze można było uzyskać nieśmiertelność, jaką osiągnął Najwyższy Lama Szangri - La czy piękna dziewczyna z Mandżurii Lo Tsen grająca Chopina w tym bajkowym miejscu w Himalajach.

Podczas spotkania głównego bohatera książki Conway’a z Najwyższym Lamą usłyszał w czasie z nim rozmowy między innymi te słowa:

2 J. Drózd, I. Drózd, Mustang. Buddyjskie Królestwo Lo, Warszawa 2001; M. Gołębiowska, Daleko. Buddyjskie Królestwo Mustangu, Wołowiec 2019; M. Kalmus, Tybet. Legenda i rzeczywistość, Kraków 2008; J. Sieradzan, Zmotoryzowani Tulku. Zachodnie reinkarnacje tybetańskich buddystów, Warszawa 2018; T. Terzani, Mustang. Raj utracony [w:] idem, W Azji, tłum. J. Wajs, Warszaw 2010; H. Uhlig, Tybet, Kraj zakazany otwiera swe wrota, przekład A. Staniewska, Katowice 2008.

${ }^{3}$ J. Hilton, Zaginiony horyzont, tłum. W. Chwalewik, wstęp i weryfikacja J. Kania, Katowice 1989. 
Zaznasz rozkosznego spokoju, dni będą ci płynęły jak innym godziny, a przy tym o ileż pogodniej! Rok będzie mijał za rokiem, a ty z wolna od satysfakcji cielesnych przechodzić będziesz ku innej, uboższej, lecz nie mniej prawdziwie przyjemnej sferze przeżyć. Prawda mięśnie kiedyś zwiotczeją i apetyt osłabnie, lecz straty zostaną ci powetowane inaczej. Spokój, przenikliwość spojrzenia, dojrzały sąd o rzeczach, mądrość, pamięć cudownie jasną - to wszystko pozyskasz w zamian. No i rzecz najcenniejszą, nagrodę najbardziej ze wszystkich upragnioną - czas. Czas dla siebie, którego Europejczycy mają coraz mniej, a którego coraz bardziej pożądają. ${ }^{4}$

Tajemnicza kraina ukryta pośród himalajskich wzgórz do dziś jest dla wielu ludzi z Zachodu, Europejczyków, Amerykanów, Kanadyjczyków i nie tylko dla nich, w dalszym ciągu krainą wyśnioną, oazą mądrości i spokoju. Z pewnością miał na to wpływ James Hilton, przepowiadając w dodatku koszmar kolejnej wojny światowej, tego co dotknie ludzkość, która jeszcze miała w pamięci bolesne wydarzenia pierwszej wojny. Zapewne i Siedem lat w Tybecie, książka i film spopularyzowały wiedzę i zaważyły na wyobraźni człowieka. ${ }^{5}$ Tybet, tak jak i zaginione królestwo Górnego Mustangu, Królestwo - Lo przyciągają ludzi poszukujących duchowości, jakże często rozczarowanych „religijnością”, która nie pomogła w powstrzymaniu dwóch wielkich wojen i nadal, jak należy sądzić, nie pomaga współczesnemu człowiekowi w jego zmaganiach z rzeczywistym światem.

Jazda $\mathrm{z}$ Katmandu do Pokhary z naszymi przewodnikami przypomniała nam wszystkie poprzednie wyprawy. Po raz piąty jedziemy tą trasą zatłoczoną w obydwie strony. Wieczorem docieramy do hotelu położonego najbliżej lotniska. Rankiem, obudzono nas gdy, było jeszcze ciemno, taksówka zawiozła naszą ekipę na lotnisko. Przeszliśmy do sali odpraw. Lot miał być o dziewiątej rano, ale z powodu złych warunków atmosferycznych, nad doliną Kali Gandaki rozszalała się burza, co spowodowało wstrzymanie lotów. Czekaliśmy w poczekalni lotniska do samego południa. Gęstniał tłum turystów ale też i mieszkających w rejonie, do którego mieliśmy lecieć. Amerykanie,

${ }^{4}$ J. Hilton, op. cit., s. 138.

${ }^{5}$ H. Harrer, Siedem Lat $w$ Tybecie, tłum. E. Waldeck-Kurtyka, Poznań 2017; J. Sieradzan, op. cit., s. 14-20. 
jak zwykle dobrze zorganizowani mieli wykłady, które prowadził ich przewodnik. Młody chłopak, z którym rozmawiałam nie słuchał wykładu, tylko cały czas spędzał w laptopie. Swoja drogą jakoś nie przyszło mi do głowy, żeby na wędrówkę w Himalajach brać ze sobą komputer. Żałuję, że nie spytałam go o cel podróży, pomyślałam sobie, że pewnie leci do którejś z fundacji amerykańskich, które potem napotkamy w Marphie.

Jest nasz lot. Lecimy w chmurach, ale co jakiś czas lepsza widoczność pozwala spojrzeć na dolinę wijącej się czarnej rzeki, na wioski poukładane na zboczach gór, ścieżki, po których wędrują mieszkańcy i turyści. Lądujemy w Jomsom. Pamiętam to miejsce z poprzedniej wyprawy, ponieważ wytraciliśmy sporo czasu czekając na samolot, nie ma mowy o zatrzymaniu się nawet na herbatę. Idziemy trzy godziny do Kagbeni i tam nocujemy a następnego dnia jeszcze zatrzymujemy się dłużej w oczekiwaniu na sprawdzenie dokumentów.

To stąd rozpoczyna się nasza wędrówka po tajemniczym Królestwie - Lo, Górnym Mustangu (Upper Mustang).

Wędrujemy do Chele wzdłuż Kali Gandaki Nadi, odchodząc od rzeki, wśród wzgórz z tufu, które przypominały mi nieco Kapadocję. Krajobraz pierwszego dnia nieco mnie rozczarował, w oddali lśniły śnieżne szczyty górskie, sięgające sześciu tysięcy metrów nad poziomem morza. Szliśmy po piaszczystych szlakach, wokół dominował koloryt szarego piasku. Skały i jaskinie skalne przypominały budowle z piasku pustynnego. Ale gdy dochodziliśmy do wioski Chele przechodząc przez rzekę, znalazłam sporo pięknych amonitów, których nie wolno wywozić z Nepalu. Czarne skorupki łatwo można było otworzyć. A wewnątrz tych ciemnych skamielin kryły się i czekały na mnie, jak myślałam, te pięknie skręcone muszle $\mathrm{z}$ bogactwem pofałdowań, które pozwoliły na cofnięcie się w wyobraźni do czasów prastarego Oceanu Tetydy, miliony lat temu. Uczeni uważają, iż Ocean ten tworzyło kilka mórz, które zanikały na skutek wypiętrzania się dna i oddzielania się kontynentów.

Zbliżając się do wioski, słychać już było z dala odgłosy zwierząt i ludzi, zapach palenisk. Zmęczenie wówczas ustępuje, bo perspektywa odpoczynku, dodaje ponownie sił. Było nie było, osiem godzin 
marszu z krótkim odpoczynkiem w południe dawało o sobie znać. Tego pierwszego dnia nie ogarniał mnie zachwyt nad tajemniczym królestwem. Może sprawił to wiatr, brak słońca, dość jednostajny krajobraz a może po prostu moja wyobraźnia podsuwała mi inne obrazy. Krajobraz był w istocie surowy i dopiero pierwsza gompa zadziwiła nas bardzo. Ten czerwono - ceglany kolor gompy będzie nam teraz towarzyszyć podczas dalszej wędrówki.

Następnego dnia ruszyliśmy do Syanboche na prawie czterech tysiącach metrów n.p.m. Dzielni ludzie, że zdecydowali się zamieszkać na tej pustynno - górskiej ziemi. Był koniec października na polach już nie było śladu po uprawach zboża, czy gryki. Mało urodzajna ziemia $\mathrm{z}$ trudem dawała pożywienie, dodatkowo jeszcze potrzebującym - uchodźcom z Tybetu.

W książce Magdaleny Gołębiowskiej, admiratorce tego buddyjskiego królestwa czytamy także o jej wrażeniach, podobnych w jakiejś mierze do naszych. Autorka Wraca do swej ulubionej krainy i pozostaje niewątpliwie jego wielbicielką. ale co konieczne podkreślenia i podziwu - pomaga dzieciom, jako współzałożycielka Fundacji Szkoły na Końcu Świata. Zwraca on uwagę na zjawisko, które obserwować można podczas także wielu innych wypraw szlakami himalajskimi. To co, podróżnicy, misjonarze próbowali bądź narzucać lub łączyć w jakimś dziwnym synkretyzmie, religii i kultur, teraz zaobserwować można współistnienie, ale jakby w oderwaniu wzajemnym, tych „doskonałości” wynalazków cywilizacyjnych, także chińskich przecież z tkwieniem w starym sposobie życia, na które owe wynalazki wcale nie mają przemożnego oddziaływania. Pasterze przepędzają stado mułów i osłów, tak jak robił to jego przodek sprzed wieków. Są pewnie podobnie nawet ubrani, tyle że teraz młody człowiek ma na uszach słuchawki i dźwięki dudnią niekiedy tak głośno, że przechodzący słyszą muzykę. W chatach, w których zatrzymujemy się na posiłek, czy nocleg dudni z kolei telewizor. Młodzi oglądają chętnie transmisje wydarzeń sportowych, najchętniej piłkę nożna, dziewczyny i starsze kobiety tasiemce produkcji Bollywood.

Jak zauważyła autorka wspomnianej książki, ludzie zamieszkujący Górny Mustang (Upper Mustang) choć zainteresowani są 
jak najbardziej światem współczesnym, to wcale nie porzucają swojej religii:

Czorteny, miejsca kultu zawierające relikwie i symbolizujące obecność Buddy, według miejscowych nadal strzegą wiosek przed złymi duchami, tak jak strzegły ich przez stulecia. Klasztory odznaczają się ceglastym kolorem na tle szarych skal, niczym uśpieni wartownicy. Mimo drogi umożliwiającej ruch kołowy na głównym szlaku do stolicy, jego odnogi, czyli wąskie ścieżki, które dostrzec można dzięki niewysokim kopczykom ułożonym z drobnych kamieni, wciąż biegną $\mathrm{w}$ tych samych kierunkach co dawniej. Wypłowiałe flagi na przełęczach powiewają, modląc się w powierzonych im intencjach, długie rzędy młynków modlitewnych ciągnących się wzdłuż murowych w sentencje religijne, na to, by ktoś minął je prawą strona. ${ }^{6}$

Było dość ponuro, gęsta mgła nie pozwalała na rozejrzenie się po okolicy, zresztą zmęczenie i wysokość jeszcze dodatkowo zniechęcały do jakiejkolwiek aktywności. Dotarliśmy w końcu na miejsce. Rankiem pogoda wcale się nie poprawiła ale trzeba było ruszać dalej w kierunku północnym. Szłyśmy pokonując wysokości, przełęcze na sporych wysokościach $\mathrm{w}$ śniegu na zmianę $\mathrm{z}$ deszczem. Obiecywane piękne widoki były niedostępne za ścianami mgły, chmur, deszczu i śniegu. Po sześciu godzinach podróży, przemoczone i przemarznięte zostałyśmy „doprowadzone” przez naszych przewodników do Ghami (Ghemi), położonej na 3520 m n.p.m. Przy gorącym posiłku, złożonym ze średnio smacznej wodnistej zupy i ryżu z sosem pomidorowym z puszki i gorącej herbaty ze sproszkowanym imbirem udało się namówić gospodarzy schroniska do zawiezienia nas dżipem do kolejnego miejsca zaplanowane wyprawy do Chrangu. Na ten sam pomysł wpadła też grupa turystów francuskich, którzy wcześniej minęli nas na przełęczy. Też byli zmarznięci i bardzo niezadowoleni z powodu tej podłej pogody. Deszcz ze śniegiem nie ustępował. Nie mogłyśmy, czego bardzo potem żałowałyśmy przejść wzdłuż najdłuższej w całym Mustangu ściany - Mani Wall. Widziałyśmy ją jedynie z okienka samochodu, którym przemierzałyśmy dalszy odcinek. Była

${ }^{6}$ M. Gołębiowska, op. cit., s. 33. 
już noc, w każdym razie, tak nam się wydawało gdy dotarłyśmy do hotelu w Charangu (Tsarangu).

Rankiem, po przebudzeniu zauważyłam, zniknięcie mojej towarzyszki wyprawy. Spojrzałam w okno, które wychodziło na podwórko osłonięte dachem. Kiedy wpadła znienacka zguba, nie chciałam jej uwierzyć, że ujrzała błękit nieba. A jednak okazało się to prawdą. Pod nami huczały rzeki, głębokie wycięcie ujścia rzeki Charang Kola, która prowadziła do przepaści, gdzie płynęła Kali Gandaki. Na niebie nie było nawet obłoczka, byłyśmy wśród pustynnych gór z przylegającymi kolumnami skalnymi, klifami z cieniutką powłoczką śnieżną i z tej delikatnej w odcieniach mieszanki szarości i błękitu wyrastały nam rdzawo, niebiesko białe czorteny. Stupy, gompy, forteca, dawny pałac królewski, w którym mieściła się wielka biblioteka, jak bardzo przywodziła na myśl opis biblioteki z "Zaginionego horyzontu” Jamesa Hiltona.

Wyruszyliśmy wreszcie do stolicy Królestwa do Lo Manthanangu. Sześćsetletnią stolicę Mustangu powitaliśmy już po zachodzie słońca. ${ }^{7}$

Stolica Królestwa Lo została założona przez Ame Pala (13871447), który oderwał swą krainę Mustangu od zwierzchnictwa jednego z rozpadających się w Tybecie księstw Gungtangu. Te trzy nota bene księstwa rywalizowały ze sobą po południowej stronie himalajskiego pasma - Purang, Gugtang i najsilniejsze Guge (Szang-Szung).

W okresie największego rozkwitu tej dynastii zapoczątkowanej przez słynnego Ama Palę podbijano tereny wokół. Dolina Kali Gandaki stała się w następnych stuleciach ożywionym szlakiem handlowym. Budowano nowe osady, na południu powstało Kagbeni, Jomsom, stolica dystryktu. Na północy w drodze do Lo Mantanangu powstały Chuksang, Ćele (Czele), Ghami.

Złoty okres dla Mustangu trwał do polowy XVI wieku, prowadzone wojny $\mathrm{z}$ sąsiadami, wewnętrzne spory doprowadziło do zmniejszenia obszaru królestwa, ograniczonego do doliny Kali Gandaki. Ponadto dalajlamowie $\mathrm{z}$ Lhasy uważali te krainę za zależną od

${ }^{7}$ Lo Manthang (Lomanthanag), Historia, https://en.wikipedia.org/wiki/Lo_Manthang [20.10.2020]. 
nich. Pod koniec XVIII wieku osłabione Królestwo Lo złożyło akt poddańczy wojowniczym Gurkhom, pierwszemu władcy zjednoczonego Nepalu, jakim byl Prithiwim Narajan. Szlak solny z Tybetu, karawany wiozące towary w obu kierunkach, tętniące przy tej okazji życie tubylców zamarło w roku 1959, w którym Chińska Republika Ludowa okupując Tybet, pozamykała przejścia graniczne z najważniejszym na przełęczy Kora La na 4660 m n.p.m.

Kiedy podeszłyśmy pod bramę pałacu królewskiego wydawał się dość ponury, z licznymi rysami na ścianie frontowej, które świadczyły o poważnym uszkodzeniu przez ostatnie trzęsienie ziemi. Sympatyczna mieszkanka tej niezwykłej stolicy opowiedziała, że nie spotkamy tu nikogo z rodziny królewskiej, bo wszyscy przebywają teraz w Katmandu. Król Dzigme Dorda Palbar Bista wraz ze swoją małżonką Tybetanką Rani Sahib zimy spędzał zwykle w Katmandu przede wszystkim ze względu na swój stan zdrowia. Dwudziesty piąty następca Ame Pala zmarł niecały rok później, po naszej wizycie w Mustangu, w grudniu 2016 roku.

Chodziłyśmy po uliczkach oglądając stare gompy, świątynie, klasztory. Nie można było wchodzić do środka ale i tak czułyśmy się jak bohaterowie Zaginionego Horyzontu. W każdym napotykanym mnichu widziałyśmy lamów „istniejących poza czasem”. Lamowie pamiętali czas przedtybetański, jak zapewniał w powieści jeden $\mathrm{z}$ jej bohaterów Czang. Twierdził on, że „Jednym z pierwszych kroków wiodących do oczyszczenia umysłu jest panoramiczna wizja własnej przeszłość, te zaś najlepiej widzieć w perspektywie". Wskazywał na ważne, przełomowe wydarzenia, „momenty szczytowe”, którymi może być na przykład wizyta złożona pewnemu człowiekowi. ${ }^{8}$

Powędrowaliśmy następnego dnia w kierunku słynnej przełęczy Kora La, do granicy z Tybetem w Chinach.

${ }^{8}$ J. Hilton, op. cit., s. 152. 


\section{References}

Drózd J., Drózd I., Mustang. Buddyjskie Królestwo Lo, Warszawa 2001.

Gołębiowska M., Daleko. Buddyjskie Królestwo Mustangu, Wołowiec 2019.

Harrer H., Siedem Lat w Tybecie, przekład E. Waldeck-Kurtyka, Poznań 2017.

Hilton J., Zaginiony horyzont, tłum. W. Chwalewik, wstęp i weryfikacja J. Kania, Katowice 1989.

Kalmus M., Tybet. Legenda i rzeczywistość, Kraków 2008.

Lo Manthang (Lomanthanag), Historia, https://en.wikipedia.org/wiki/Lo_Manthang [20.10.2020].

Sieradzan J., Zmotoryzowani Tulku. Zachodnie reinkarnacje tybetańskich buddystów, Warszawa 2018.

Terzani T., Mustang. Raj utracony [w:] idem, W Azji, tłum. J. Wajs, Warszaw 2010. Uhlig H., Tybet, Kraj zakazany otwiera swe wrota, przekład A. Staniewska, Katowice 2008 . 


\title{
Anna Horniatko-Shumylovych
}

Adam Mickiewicz University in Poznań (Poland)

ORCID: 0000-0003-1625-6193

\section{Забуті імена: Василь Ткачук очима родичів й односельчан (на основі актуальних інтерв'ю)}

\section{Forgotten names: Vasyl Tkachuk in the eyes of relatives and countrymen (based on recent interviews)}

\begin{abstract}
:
Vasyl Tkachuk (1916-1944) is a forgotten talent of the Ukrainian literature of the 1930s. Not so long ago this outstanding short-story writer was completely unknown to a wide range of readers. Today his memory is being laboriously restored. His artistic profile, personal features, and his surrounding's attitude to the author may be described to readers thanks to the recent interviews with his close relatives and the residents of his home village and region. Memories of the people who met Vasyl Tkachuk or remember him from their relatives' stories prove the writer's exceptional nature and his writing career, which was stopped by his death.
\end{abstract}

Keywords: forgotten talent, recent interview, writer's artistic profile, Ukrainian literature.

\section{Вступ. Забуте ім'я Василя Ткачука}

Коли 2011 року бібліограф-краєзнавець Івано-Франківської обласної бібліотеки для юнацтва Ярослава Бідичак проводила для учнів природничо-математичного ліцею краєзнавчу годину до 95-річчя від дня народження українського новеліста 30 -х років ХХ ст. Василя Ткачука, з цілим переконанням підкреслювала:

Мало, дуже мало залишилося після В. Ткачука, кілька збірок, що повернули зі спецхронів, трохи листів до друзів і ще менше фотографій. Для 
місцевих краєзнавців це непочатий край роботи. Адже нічого не відомо про дружину і доньку письменника (навіть імен), батьків, братів і сестер. Нічого не відомо, якими були останні роки і дні життя самого Василя Ткачука. Де шукати його сліди? На полях битв чи у застінках НКВД. [...] I нині прибалтійські вітри засівають мжичкою його забуту могилуㄹ․

I не знала тоді згадана бібліограф-краєзнавець, що кількадесят кілометрів від Івано-Франківська в рідному селі письменника наполегливий учитель хімії Роман Ризюк уже майже тридцять років шукає його сліди і має свої успіхи. Не знала, що в Іллінцях живе родичка Василя Ткачука, а в далекому Щецині через два роки, вціліла з воєнної завірюхи єдина дочка письменника публікуватиме збірне видання творів свого і для неї невідомого, передчасно померлого батька.

\section{1. Слідами творчості Василя Ткачука}

Приблизно три роки досліджень творчої дороги Василя Ткачука (1916-1944) дозволили мені зібрати доволі цікавий матеріал для аналізу його художньої спадщини. Варто підкреслити, що поміж сучасних дослідників Ткачукової новелістики, можна назвати поодинокі імена, такі як Роман Горак, Степан Хороб чи Христина Федор (дівоче Синітович)². Результатами моїх роздумів став

${ }^{1}$ Kraieznavcha hodyna „Zoloti dzvonyky Vasylia Tkachuka”, http://www.ylibif. at.ua/news/kraeznavcha_godina_zoloti_dzvoniki_vasilja_tkachuka [2011-0316-31].

2 R. Horak, Zahublenyi talant Vasylia Tkachuka [w:] V. Tkachuk, Zoloti dzvinky, Apriori, Lviv 2014, s. 239-303; R. Horak, Vasyl Tkachuk z Illintsiv, ch. 3-4, „Pereval”, 2015, s. 294-304; S. Khorob, Odyn iz kohorty uchniv slavetnoho novelista (Prozova tvorchist V.Tkachuka) [w:] „Visnyk Dnipropetrovskoho universytetu im. Alfreda Noblia. Seria „Filolohichni nauky”, 2013, № 2(6), s. 222-228; Kh. Fedor, Vasyl Tkachuk v zakhidnoukrainskomu literaturnomu ta kulturnomu protsesi pochatku XX stolittia [w:] „Humanitarna osvita v tekhnichnykh vyshchykh navchalnykh zakladakh”, 2014, №29, s. 260-278.; Kh. Fedor, Vasyl Tkachuk kriz pryzmu rozhortannia nym stefanivskykh tradytsii [w:] „Humanitarna osvita v tekhnichnykh vyshchykh navchalnykh zakladakh”, 2015, № 31, s. 231-243; Kh. Fedor, 
цикл статей, присвячених окремим аспектам поетики й проблематики новелістики Ткачука, зокрема образам, концептам і символам, що зумовлюють унікальність Ткачукового прозопису. Образ бурі, концепт вітру чи символ чічки, аналізовані мною в окремих статтях, склали підгрунтя ширшої розвідки про натурфілософію як феномен художнього світу Василя Ткачука ${ }^{3}$. Окреме дослідження я присвятила традиції і новаторству у творчості письменника, підкреслюючи багатогранність його художнього доробку - з одного боку зануреного в українську класику, зокрема стефаниківську новелу „концентрації чуття”, з другого - спраглого новаторських пошуків, зокрема на рівні надзвичайно багатої стилістичної палітри ${ }^{4}$ Попри факт, що, за словами критиків 30-х років, Василь Ткачук „постає як світлий пророк майбутнього, вірить у добро, живе з надією у краще"”, в його новелах широко репрезентовані мотиви й образи смерті,

Kolorystyka tvoriv Vasylia Tkachuka ta yii rol u vysvitlenni ideino-khudozhnikh dominant prozy pysmennyka [w:] „Humanitarna osvita v tekhnichnykh vyshchykh navchalnykh zakladakh”, 2014, № 30, s. 235-243; Kh. Fedor, Istoryko-kulturna spadshchyna Vasylia Tkachuka ta osoblyvosti yoho khudozhnioho myslennia [w:] „Spheres of Cilture”, volume VIII, Maria Curie-Sklodovska University, Lublin 2014, s. 97-105; Прикметно, що у 30-х роках XX ст. новелістична творчість Василя Ткачука була у полі зору зацікавлень багатьох тодішніх критиків і літературознавців. Детальніше на цю тему дивись статтю: A. Horniatko-Szumiłowicz, „Skromne obrazki wiejskie” Wasyla Tkaczuka (szkic do portretu pisarza zapomnianego) [w:] Studia et Documenta Slavica, nr 1, red. J. Czaplińska,: Wydawnictwo Uniwersytetu Opolskiego, Opole 2017, s. 9-21.

3 A. Horniatko-Shumylovych, Naturfilosofia yak fenomen khudoznioho svitu Vasylia Tkachuka [w:] „IX Mizhnarodnyi konhres ukrainistiv. Literaturoznavstvo. Zbirnyk naukovykh statei (do 100-richchia Natsionalnoi akademii nauk Ukrainy)", red. S. Pyrozhkov, A. Zahorodnii, H. Skrypnyk, NAN Ukrainy, IMFE im. Rylskoho, Kyiv 2018, s. 21-36.

${ }^{4}$ A. Horniatko-Shumylovych, Vasyl Tkachuk. Mizh tradytsiieiu i novatorstvom. Narys problematyky [w:] „Tożsamość ukraińska wobec przemian XVII-XXI w.”, red. K. Jakubowska-Krawczyk, A. Nowacki, Wydawnictwo KUL, Lublin 2017, s. 141-157;

${ }^{5}$ Kh. Fedor, Vasyl Tkachuk kriz pryzmu rozhortannia nym Stefanuvskykh tradytsii, s. 241. 
дослідженню яких я присвятила чергову статтю6 . Об'єктом моєї пильної уваги стала й небувала майстерність змалювання Ткачуком жіночих образів, оскільки письменник присвятив героїням чи не найбільше творчої наснаги у своїх творах, починаючи від образу дівчинки, через дівчину, молодицю, матір, бабцю, тещу аж до збірної картини жіноцтва7. I, врешті, заради грунтовного дослідження історико-літературного контексту, в якому функціонував непересічний новеліст, я проаналізувала його внесок у творче зростання маловідомого донедавна авангардного угруповання „Дванадцятка”, що діяло у Львові в роках 1935-1939, і в якому Ткачук був відомий як „Гуцулик”8.

\section{2. Три розмови в Україні й одна в Польщі}

Оскільки, володіючи певними ресурсами літературознавчих та теоретичних знань, звичайно, за умови доступу до творчої спадщини даного письменника, можливо доволі влучно проаналізувати її художність, остільки його життєвий шлях, характер, особистисні якості найкраще пізнаються на основі листів чи спогадів самого письменника або, коли їх немає (як по суті це сталося у випадку Василя Ткачука), через розмову з очевидцями чи людьми, якимось чином, близькими даному творцю.

${ }^{6}$ A. Horniatko-Shumylovych, Na terezakh doli(Motyvy i obrazy smerti u novelistytsi Vasylia Tkachuka) [w:] „Slavica Wratislaviensia CLXVIII. Wielkie tematy kultury w literaturach słowiańskich 14. Tanatos 2", red. E. Tyszkowska-Kasprzak, G. Durdev-Małkiewicz, M. Świetlicki, D. Żygadło-Czopnik, Wydawnictwo Uniwersytetu Wrocławskiego, Wrocław 2019, s. 123-135.

7 A. Horniatko-Shumylovych, Maisternist zmaliuvannia zhinochykh postatei $v$ novelistytsi Vasylia Tkachuka [w:] „Kobieta w zwierciadle języka i kultury”, red. A. Archangielska, M. Hordy, Wydawnictwo Naukowe Uniwersytetu Szczecińskiego, Szczecin 2017, s. 481-499.

${ }^{8}$ A. Horniatko-Shumylovych, Iz metoiu "pidshukuvannia novykh dynamichnykh form vyslovu”. "Dvanadtsiatka” yak avanhardne javyshche $v$ ukrainskii literaturi [w:] „Poznańskie Studia Slawistyczne” nr 18, Wydawnictwo Poznańskiego Towarzystwa Przyjaciół Nauk, Poznań 2020, s. 125-144. 
Одним із таких способів є інтерв’ю - „метод одержання необхідної інформації шляхом безпосередньої цілеспрямованої бесіди інтерв'юера з респондентом. [...]. Інтерв'юеру відводиться ведуча роль ініціатора в організації і проведенні бесіди, в той час як респондент виступає у ролі веденого, в ролі джерела інформації" 9 . Це, звичайно, основний метод збирання інформації в соціології, журналістиці та психології, але й літературознавстві.

Влітку 2018 року вдалось мені побувати в „малій батьківщині” Василя Ткачука, де він ступав босоніж, „наелектризовуючись від землі". У рідному селі Іллінці Снятинського району, 9-го серпня згаданого 2018 року, я провела три інтерв’ю: з Людою Шиховою дочкою Романа Ризюка, багатолітнього директора Народного музею історії села Іллінці, пристрасного збирача і пропагандиста творчості Василя Ткачука; з Анною Федорійчук - віднайденою родичкою письменника, онукою рідної сестри його матері, яка живе в Іллінцях, але досі не знала дочки письменника; із Миколою Сулятицьким - земляком Ткачука - гуцулом, вихідцем із Снятинщини, професором Кафедри українознавства і філософії Івано-Франківського національного медичного університету. Ще до поїздки в Іллінці, 4-го серпня 2018 року, я організувала інтерв'ю з дочкою письменника - Ольгою Гоффманн (нар. 1938), яка, як виявилось, і це також свого часу було для мене відкриттям, живе в північно-західній Польщі, у Щецині.

Попробуємо систематизувати зібраний матеріал, спираючись насамперед на теорію інтерв'ю.

За формою інтерв'ю (дослідники виділяють чотири його типи: стандартизоване, глибинне, фокусоване й вільне ${ }^{10}$ ), я провела три змішаних. Розмови з Ольгою Гоффманн, Людою Шиховою й Миколою Сулятицьким були сумішшю фокусованого, стандартизованого й глибинного інтерв'ю, тоді як 3 Анною Федорійчук - фокусованого й вільного. Як правило, усі чотири інтерв'ю мали характер фокусованих, тобто спрямова-

9 V. Picha, Sotsiolohia: zahalnyi kurs, Karavela, Kyiv 2000, s. 212.

10 Ibidem, s. 212-213. 
них на вивчення думки співорзмовника відносно конкретного факту - забутого таланту Василя Ткачука. Водночас бесіди 3 трьома першими респондентами були, якоюсь мірою, стандартизовані, заздалегідь підготовлені. Ольга Гоффманн та Микола Сулятицький отримали запитання електронною поштою, мали час підготуватися до відповідей. Формулювання запитань, їх порядок, кількість, а навіть можливі відповіді, якоюсь мірою, передбачались. Водночас згадані три розмови містили елементи глибинного інтерв'ю, оскільки їхньою метою було отримати інформацію, яка не тільки засвідчувала б наявність того чи іншого факту, явища (спогади про Василя Ткачука), але й пояснювала причини появи даних фактів, явищ. Це зокрема торкалось інтерв'ю, проведеного з Миколою Сулятицьким, який з'ясував причини конкретних виборів письменника (захоплення приходом радянської влади у Львів восени 1939 року, присутність у його творах мотивів братовбивчих сутичок, образів зрадника-перекинчика тощо), віддзеркалюючи доволі широкий суспільно-політичний контекст.

Бесіда 3 Анною Федорійчук, хоча фокусована на зібрання інформації про Василя Ткачука, мала характер вільної. Не знаючи про зустріч з віднайденою родичкою письменника, я не склала плану інтерв'ю, не сформулювала завчасно питань, респондентка також, звичайно, їх не отримала. Звідти перші їі слова: „Моя бабуся, а його мама - Ткачука Василя, були рідні сестри. А моя мама з Василем Ткачуком вже були перві [двоюрідні - А. Г.-Ш.]"11 - висказані на підтвердження автентичності кровної спорідненості з письменником.

3 огляду на кількість мовників, усі розмови належали до різновиду інтерв’ю-діалогу, тобто бесіди за схемою „питання + відповідь”. Як правило, одночасно з основними питаннями,

11 Дана цитата (записана курсивним шрифтом) і всі інші, що є частиною вищевказаних чотирьох інтерв'ю, зберігаються в архіві авторки статті. Передбачається їхня публікація у планованій мною монографії про життя і творчість Василя Ткачука. 
я ставила співрозмовникам уточнюючі, додаткові питання, за ïх допомогою направляючи бесіду в потрібне русло, з'ясовуючи деякі нюанси, цікаві деталі, факти. Так, наприклад, уточнюючий характер мали запитання, звернені до Люди Шихової, про дату відкриття та чергові етапи організації Народного музею історії села Іллінців. Ми допитали також Миколу Сулятицького, як, на його погляд, склалось би життя Ткачука, коли б він вижив, але водночас змушений був функціонувати в умовах кон'юнктурних 40-50-тих років в Україні. Звичайно, такі питання надали процесу розмов відповідної драматургії, інтонаційного багатства, роблячи матеріал розмови сюжетним, інтригуючим.

3 огляду на спосіб спілкування, три з проведених мною інтерв'ю мали безпосередній характер, т.зв. обличчям до обличчя, під час яких проводився запис на диктафон. Одна - розмова з Ольгою Гоффманн відбулась кількаразово не для запису, причому інформацію, отриману під час бесіди, можна було використати, а остаточний варіант інтерв'ю дочка письменника передала у письмовій формі.

3 огляду на місце проведення інтерв'ю12, розмови 3 Людою Шиховою та Анною Федорійчук відбулись на робочому місці, тобто в Народному музеї історії села Іллінці, розмова з Миколою Сулятицьким проведена була в т.зв. інтер-ситуації (коломийському готелі „Писанка”), так само з Ольгою Гоффманн кількаразово в інтер-ситуаціях (у моєму домі в Щецині за кавою, в українській домівці в Щецині).

За метою, яку я хотіла реалізувати, усі чотири розмови були, скоріше всього, сумішшю документального інтерв'ю з інтерв'ю думок $^{13}$. У кожній бесіді наявний був елемент установлення конкретних фактів з життя Василя Ткачука в поєднанні зі спробою оцінювати дані факти в контексті життя письменника. Так, наприклад, Микола Сулятицький не лише широко представив суспільно-політичний контекст, в якому жив і творив Василь

\footnotetext{
12 V. Picha, Sotsiolohia: zahalnyi kurs, Karavela, Kyiv 2000, s. 213.

13 Ibidem, s. 213.
} 
Ткачук, але й пояснив конкретні життєві вибори письменника, зумовлені саме політичною кон'юнктурою. За його словами, „він [Василь Ткачук - А.Г.-Ш.] не був кон'юнктурним письменником, хоча жив в кон'юнктурній ситуачї. Однозначно". Так само й Ольга Гоффманн не лише розповіла про основні віхи життєвого шляху батька, наприклад, історію знайомства і подружнього життя з ії матір'ю, Марією Януш, але й попробувала з'ясувати причини розриву супружжя батьків, суть проблеми вбачаючи скоріш за все в неспокійній натурі письменника:

3 часом прийшла любов, через що вони стали супружжям, ідеалізованим матір'ю. На жаль, мій батько був джияуном. Це красень, тому там, де з'являвся, завжди оточувався табунием дівчат і жінок, які припадали біля нього. Знаю, що мама страждала з иього приводу. Неохоче про ие розповідала,

\section{і далі}

від природи щедро обдарований, натура не поскупилася йому на вроду й чарівливість. 3 того, що мені відомо, любив розгульне життя, хотів перебувати в иентрі зацікавлення, міг повести себе зухвало, не завжди був акуратний. У подружньому житті скоріш за все тяжкий, зі схильністю до гулянок, танию, нічного життя.

До речі, про непокірну вдачу Ткачука кількаразово згадувала родичка, Анна Федорійчук, вбачаючи у цьому, так само як і Ольга Гоффманн, якийсь елемент вільнодумства, широкої натури, характерної для непересічних особистостей („Він такий був непокорний. Він нікого не признавав. Не хотів з [...] панством, ні з ким зв'язуватися").

\section{3. Унікальність проведених інтерв'ю}

Кожне з інтерв’ю мало свій характер, свою специфіку, що відрізняло його від решти. Кожне з них унікальне і дає цінну інформацію про „загублений талант” Ткачука. 
Розмова з Людою Шиховою дала уявлення про надзвичайно копітку працю, яку зробив їі батько для „повернення із забуття в безсмертя" імені Ткачука та його творчої спадщини, особливо в Снятинському районі. Завдяки цьому інтерв'ю уточнено факти щодо встановлення та функціонування Народного музею історії села Іллінці, в якому окремий стенд виділений Ткачукові, а також щодо відкриття меморіальної дошки йому присвяченої.

Інтерв'ю з Миколою Сулятицький послужило засобом збору інформації про специфіку життя в Снятинському районі у 30-40-х роках минулого століття. Згадана розмова дала також відповідь на складні питання про стосунки між тодішніми українцями-автохтонами й поляками, росіянами, євреями.

Співбесіда з Ольгою Гоффманн - найбільш інтимізована, оскільки дочка письменника розповіла про свої очікування щодо відновлення забутого імені батька, висловила жаль з приводу неможливості реалізувати звичайні реляції дитина-батько, згадала непрості відносини письменника з дружиною, відшукала в себе спільні з ним риси характеру.

Особливо неочікуваною виявилась розмова з віднайденою родичкою письменника - Анною Федорійчук. Хоча найкоротша з усіх чотирьох, чи не найкраще показала ставлення родичів до Ткачука як до постаті унікальної, яка сильно вирізнялася на тлі родичів і тодішніх односельчан.

Власне кажучи, спільною рисою усіх чотирьох інтерв'ю був акцент на винятковість постаті Василя Ткачука. Зокрема співрозмовники з України, уродженці Снятинщини, тісно зв'язані 3 місцевою культурою і традицією, підкреслювали непересічність новеліста. Так, наприклад, Люда Шихова, згадувала про „неординарну особистість” і щоб акцентувати винятковість дуже молодого письменника, пестливо називала його „пацаном", якому було тільки 19 років, коли імпозантним тиражем 5 тисяч примірників вийшла його перша збірка Сuні чічки (1935). Моя співрозмовниця захоплювалася його поетичним словом („я звернула увагу на красу слова”), цитувала яскраві Ткачукові метафори: 
Та сонце [...] імило білий день попід пахи й потягло його за темно-синяву бинду гонорних гір"14, [...]. А Ткачук жив тут. I коли виходив вище на вулищю, він дійсно бачив, що сонце бере день попід паху і несе за гори. Але хто бз нас сказав так, не готуючись? А в нього такі фрази виходили [...];

надіялась, що воно вплине на якість живого мовлення сучасної молоді („Ради краси слова. Як діти тепер спілкуються двома-трьома реченнями і наскільки гарно говорив Ткачук"). Водночас із здивуванням реагувала на питання про можливі кон'юнктурні моменти в життєписі новеліста, заперечуючи будьякі сліди того типу в біографії письменника. На думку Люди Шихової, „переважно він писав про простих людей”.

Микола Сулятицький не заперечував, але виправдовував захоплення письменника приходом радянської влади, пояснюючи цей факт всезагальною ейфорією жителів тодішньої Снятинщини, переповнених ілюзорною вірою в прихід радянського „визволителя” від польського ярма:

[...] спочатку саме на Покутті були певні прорадянські настрої і навіть в Музею історії села Ілліниі й в інших історичних джерелах згадується, що були значно тояльніше налаштовані на Гуиульщині, на Косівщині, на Хоменщині, на певній частині Коломийщини.

Водночас мій співрозмовник не погоджувався з закидами деяких дослідників, які ладні звинувачувати Ткачука в кон'юнктурній діяльності:

Радянський Союз мав потужну армію, зброю, але ще більша зброя - ие була ідеологія і письменники - ие якраз були ковалі иієї ідеології. Їх навіть до війська не брали, причому тільки слухняних письменників. Василь Ткачук таким не виявився, він відразу пішов на конфлікт, він дійсно побачив справжнє обличчя нової радянської влади, яка хотіла все контролювати, яка хотіла зробити письменника не естетом, а служителем системи $i$ через те нам відомо, що потім і сталося, що почалася війна, його, як і небагатьох, призвали на фронт, фактично на смерть.

${ }^{14}$ V. Tkachuk, Yabluko [w:] V. Tkachuk, Syni Chichky, Novely, peredmova Kh. Synitovych, Ivano-Frankivsk 2013, s. 161. 
Так само й Ольга Гоффманн, підкреслювала об’єктивні причини цього суспільного феномену:

Мій батько був від наймолодщих літ під впливом комуністичної ідеології, вірив в їі правомірність. Важко иьому дивуватися, оскільки зростав у бідній сім'ї, виховуваний матір'ю, удовою, яка заробляла на утримання двох синів, Олександра й Василька, і дочки Марійки послугами, вищиванням.

Ткачукова родичка, Анна Федорійчук, зі зворушенням згадувала матір письменника, Олену Ткачук, і ї̈ величезну тугу за сином:, [...] Олена, мама Василя, не так переживала тяжко за Олександром, як переживала за Васильком". Демонструвала слова пісні, яку підспівувавла Ткачукова мати:

Та Василева мама складала сама [пісні - А.Г.-Ш.]: «Тяжка зима дуже була, як я Тебе народила, а ще більще тяжча стала, коли Тебе забирали». Так вони порівнювали, що зима була, дуже поганий рік був, дуже тяжкі морози тоді були [коли він народився - А.Г.-Ш.], а коли його забрали, то ій було важче, бо його не було вже з нею.

Анна Федорійчук підтвердила, що, попри свій юний вік, відчувала, що в родині Василь відрізнявся на фоні решти членів, саме своєю винятковістю, талантом, харизматичністю. „Він такий був непокірний. Він нікого не признавав. Не хотів з таким панством, ні з ким зв'язуватися". На моє запитання, з якого віку новеліст проявляв непересічний талант, респондентка відповіла: „Змалку, змалку. I був дуже такиц̆, що моїи бабиі розказували, що напевне з нього нічого не буде".

Тут момоволі насувається порівняння із загальновідомими словами батька Тараса Шевченка, Григорія, який, умираючи, мав про нього сказати: „Синові моєму Тарасові з спадщини після мене нічого не треба. Він не буде людиною абиякою; з його вийде або щось дуже добре, або велике ледащо"15.

15 Istoriia ukrainskoi literatury. U dvanadtsiaty tomakh. Tom chetvertyi. Taras Shevchenko, red. V. Donchyk, Kyiv 2014, s. 28. 
Ольга Гоффманн підтвердила виняткове ставлення Олени Ткачук до сина, тобто їі батька:

Василько був улюбленцем матері. Найбільш тішило ї̈ його бажання вчитися. Кохала його і він любив їі великою тюбов'ю, гордився бути ії сином. Доказом иьвого хай буде факт присутності коханої матері на його шлюбі з моєю матір'ю, що відбувся у Львові в иеркві св. Миколая. Сам їі привіз із рідного села. Одягнена в гуиульське вбрання, сиділа поруч нього, на почесному місці.

Моя співбесідниця підкреслила також, що дружина Ткачука, Марія, дуже його любила і шанувала, хоча відчувала жаль: „Мати не розповідала багато, не знаю з якого приводу, думаю, що хотіла мені заощадити смутку. Якщо розповідала, то завжди тільки добре. I про його талант".

Усі співрозмовники, в принципі, уникали відповідей на питання про художні деталі творчості новеліста („Я не можу Вам про це сказати” - Люда Шихова; „Не можу Вам відповісти на це питання. Просто немає в мене знання на ию тему" - Ольга Гоффманн). Найімовірніше з приводу їх незнайомості. Адже, окрім Миколи Сулятицького, згадані респонденти не філологи за фахом. Водночас усі вони підкреслювали унікальність Ткачука як письменника („Нешліфований діамант” - Ольга Гоффманн; „[...] він мав Божий дар до слова" - Люда Шихова).

Деякі аспекти проблематики творів Ткачука з'ясовував Микола Сулятицький, зокрема передумови виникнення у прозі новеліста образів зрадника-перекинчика, утікача-дезертира, зумовлені, на його думку, польсько-українською суспільно-політичною ситуацією 30-х років ХХ ст. Водночас цей самий респондент неохоче коментував порівняння творчого методу Василя Стефаника й Василя Ткачука, акцентуючи неповторність кожного з них:

Зводити, порівнювати... У кожного є своє бачення, свій стиль. У Стефаника свій, у Ткачука свій. Це, що вони подібні, [...], через те, щзо вони з одного краю, що у них така мова. Так само в Черемшини чи Леся Мартовича. Але у Ткачука було значно більше діалектизмів, значно більще фольклорних 
елементів, тому на перший погляд здається, щз він більш поетичніший. Через те, що він менше використовував літературну мову на той час.

Ольга Гоффманн указувала на принципову відмінність між Ткачуком і Стефаником з огляду на їхній соціальний статус:

Є суттєва різниия між родиною Василя Стефаника, народженого в багатій селянській родині [i, відповідно, родиною Василя Ткачука - А.Г.-Ш.]. Його мати могла приділити належну увагу талановитому синові, тоді як бідна [Ткачукова мати - А.Г.-Ш.] неписьменна, яка працювала, щзоб утримати своїх дітей, не мала такої можливості. Стала удовою у 1922 році.

I Микола Сулятицький, і Ольга Гоффманн заперечували, що Ткачук наслідував творчу манеру Стефаника. Дочка письменника наголошувала невдоволеність батька з приводу спроб закидати йому епігонство: „Обурювався, коли порівнювали його творчість із творчістю Василя Стефаника, якого, мовляв, мав наслідувати”. Так само і Микола Сулятицький: „Однозначно, що він не наслідував. [...] А вже наука, яка приходить, вона намагається встиснути це у свої рамки. Мабуть, після иього починаються роздуми, вже чисто наукові, менш тітературні".

Підсумовуючи, новеліст Василь Ткачук оточений на рідній йому Снятинщині великою пошаною і непідкупною любов’ю, а його родичі й односельчани переповнені почуттям гордості за справжній талант. Цей самий письменник - маловідомий для широкого загалу українців у Центральній, Східній і Південній Україні і поза ії межами, в результаті чого сприймається з певною стриманістю в оцінках. Саме тому робота над розповсюдженням його безперечно унікальної спадщини повинна бути завданням сучасних дослідників і критиків.

\section{Висновки. Поступове відновлення пам'яті}

3-поміж широкої сфери застосування інтерв'ю: на ранній стадії дослідження; для розробки великих опитувань; в якості 
додаткового методу отримання інформації, для уточнення і перевірки даних i, врешті, як основний метод одержання інформації16, для даного дослідження ця остання видається найбільш корисною. Адже справді письмових свідчень про життя Василя Ткачука залишилось украй небагато.

Проведені мною інтерв'ю допомогли реконструювати доволі повний образ популярного у 30-х, повністю забутого у 50-70-х роках і відновленого нещодавно таланту Василя Ткачука.

Завдяки здійсненню планів відвідати Народний музей історії села Іллінці, дочка Романа Ризюка, Люда Шихова, спонукала Анну Федорійчук до зустрічі зі мною як дослідницею спадщини Василя Ткачука. Результатом розмови було непереборне бажання родички Анни зустрітися з дочкою письменника, яке здійснилоя 28 жовтня 2018 року у Щецині. Дві родички, які ніколи не бачились, - дочка новеліста і його племінниця - під час першої спільної зустрічі намагалися визбирати спогади із закутків своєї і чужої пам'яті і відтворити образ загубленого в часі і просторі таланту - родича і письменника.

Завершуючи, хочеться додати, що згадувана в перших словах доповіді бібліограф-краєзнавець, по суті, зараз після проведення „краєзнавчої години” дізналася про титанічну працю Романа Ризюка - скромного борця за повернення пам'яті про Ткачука і відвідала Іллінецький музей, що наголосила в розмові зі мною Люда Шихова („Якраз 2011-го чи 2012 року, коли ми захищяли ту роботу [конкурсна робота МАН України під назвою „Недосnівана пісня" Василя Ткачука - А.Г.-Ш.], вона дістала розголос і ия жінка приїндала до нас в музей і брала інформачї̈ про Ткачука").

Ось такими малими кроками і великим зусиллям окремих людей забуте ім'я Василя Ткачука поволі повертається пам'яті народу, і там на рідній письменнику Снятинщині, і далі по всій Україні, і тут в українській діаспорі в Польщі, нарешті, посеред польських любителів української культурної спадщини.

16 V. Picha, Sotsiolohia: zahalnyi kurs, Karavela, Kyiv 2000, s. 212. 


\section{References}

Horak R., Vasyl Tkachuk z Illintsiv, ch. 3-4, „Pereval”, 2015, s. 294-304.

Horak R., Zahublenyi talant Vasylia Tkachuka [w:] V. Tkachuk, Zoloti dzvinky, Apriori, Lviv 2014, s. 239-303.

Horniatko-Shumylovych A., Vasyl Tkachuk. Mizh tradytsiieiu i novatorstvom. Narys problematyky [w:] „Tożsamość ukraińska wobec przemian XVII-XXI w.", red. K. Jakubowska-Krawczyk, A. Nowacki, Wydawnictwo KUL, Lublin 2017, s. 141-157.

Horniatko-Shumylovych A., Iz metoiu „pidshukuvannia novykh dynamichnykh form vyslovu”. "Dvanadtsiatka” yak avanhardne yavyshche v ukrainskii literaturi [w:] „Poznańskie Studia Slawistyczne” nr 18, Wydawnictwo Poznańskiego Towarzystwa Przyjaciół Nauk, Poznań 2020, s. 125-144.

Horniatko-Shumylovych A., Maisternist zmaliuvannia zhinochykh postatei $v$ novelistytsi Vasylia Tkachuka [w:] „Kobieta w zwierciadle języka i kultury”, red. A. Archangielska, M. Hordy, Wydawnictwo Naukowe Uniwersytetu Szczecińskiego, Szczecin 2017, s. 481-499.

Horniatko-Shumylovych A., Na terezakh doli(Motyvy i obrazy smertu u novelistytsi Vasylia Tkachuka) [w:] „Slavica Wratislaviensia CLXVIII. Wielkie tematy kultury w literaturach słowiańskich 14. Tanatos 2", red. E. Tyszkowska-Kasprzak, G. Durdev-Małkiewicz, M. Świetlicki, D. Żygadło-Czopnik, Wydawnictwo Uniwersytetu Wrocławskiego, Wrocław 2019, s. 123-135.

Horniatko-Shumylovych A., Naturfilosofia yak fenomen khudozhnioho svitu Vasylia Tkachuka [w:] „IX Mizhnarodnyi konhres ukrainistiv. Literaturoznavstvo. Zbirnyk naukovykh statei (do 100-richchia Natsionalnoi akademii nauk Ukrainy)", red. S.Pyrozhkov, A. Zahorodnii, H. Skrypnyk, NAN Ukrainy, IMFE im. Rylskoho, Kyiv 2018, s. 21-36.

Horniatko-Szumiłowicz A., „Skromne obrazki wiejskie” Wasyla Tkaczuka (szkic do portretu pisarza zapomnianego), [w:] Studia et Documenta Slavica, nr 1, red. J. Czaplińska, Wydawnictwo Uniwersytetu Opolskiego, Opole 2017, s. $9-21$.

Istoriia ukrainskoi literatury. U dvanadtsiaty tomah. Tom chetvertyi. Taras Shevchenko, Red. V. Donchyk, Kyiv 2014.

Kraieznavcha hodyna „Zoloti dzvonyky Vasylia Tkachuka” [w:] http://www.ylibif. at.ua/news/kraeznavcha_godina_zoloti_dzvoniki_vasilja_tkachuka [2011-0316-31].

Picha V., ,Sotsiolohia: zahalnyi kurs, Karavela, Kyiv 2000.

Synitovych Kh., Zhyttievyi i tvorchyi shliakh Vasylia Tkachuka [w:] Tkachuk V., Syni Chichky, Novely, perdmova Kh. Synitovych, Ivano-Frankivsk 2013, s. 5-13. Tkachuk V., Syni Chichky, Novely, peredmova Kh. Synitovych, Ivano-Frankivsk 2013. 
Fedor Kh., Vasyl Tkachuk $v$ zakhidnoukrainskomu literaturnomu ta kulturnomu protsesi pochatku XX stolittia [w:] „Humanitarna osvita v tekhnichnykh vyshchykh navchalnykh zakladakh", 2014, № 29, s. 260-278.

Fedor Kh., Vasyl Tkachuk kriz pryzmu rozhortannia nym stefanivskykh tradytsii [w:] „Humanitarna osvita v tekhnichnykh vyshchykh navchalnykh zakladakh” 2015, № 31, s. 231-243.

Fedor Kh., Istoryko-kulturna spadshchyna Vasylia Tkachuka ta osoblyvosti yoho khudoznioho myslennia [w:] „Spheres of Cilture”, volume VIII, Maria Curie-Sklodovska University, Lublin 2014, s. 97-105.

Fedor Kh., Kolorystyka tvoriv Vasylia Tkachuka ta yii rol u vysvitlenni idejno-khudozhnikh dominant prozy pysmennyka [w:] „Humanitarna osvita v tekhnichnykh vyshchykh navchalnykh zakladakh”, 2014, № 30, s. 235-243.

Khorob S., Odyn iz kohorty uchniv slavetnoho novelista (Prozova tvorchist V.Tkachuka) [w:] „Visnyk Dnipropetrovskoho universytetu im. Alfreda Nobelia. Seria „Filolohichni nauky”, 2013, № 2(6), s. 222-228. 


\section{Eugeniusz Sobol}

\section{Skąd zło? Paradoksy rewolucji na Ukrainie O Wspomnieniach i Dziennikach Jewhena Czykałenki}

\section{Where does evil come from? Paradoxes of revolution in Ukraine. On Diaries and Memoirs of Yevhen Chykalenko}

\section{Abstract:}

In this article author focused on the Diaries and Memoirs of Yevhen Chykalenko. He has tried to reconstruct the process of creating these books and compare them. The author creatively developed the comparative analysis of Memoirs and Diaries, because the first book is characterized by officiality, memory idyll, positive aspects of Ukraine. The second one brings bitterness and a critical judgment of his own nation. To emphasize this comparison, the author used the concept of Malgorzata Czermińska's autobiographical triangle. Reflecting on the passivity of the Ukrainian writer during the Ukrainian People's Republic, he came to the conclusion that it resulted from the philosophy of "not opposing evil with violence" by Leo Tolstoy. Between him and Chykalenko the author found more converging parallels. The author then dealt with the political myths of Chykalenko, among which he distinguished his fascination with Germany. If in Memoirs we deal with an idyllic and positive image of Ukraine and Ukrainians, catastrophic visions prevail in the dairies. It shows the fall of values, as well as the triumph of barbarism that prevailed after the revolution of 1917. Memoirs and Diaries by Chykalenko are very important for the study of the history of Ukrainian periodicals, we learn about the realities of the press, problems with censorship, editorial work, repressions.

Keywords: Yevhen Chykalenko, Diaries, Memoirs, Ukraine, Russia, Revolution, World War I, Civil War. 
W ostatnim czasie na Ukrainie wzrosło zainteresowanie postacią ukraińskiego filantropa, mecenasa, wydawcy i działacza społecznego Jewhena Czykałenki. Wiąże się to z publikacją obejmującą siedem tomów spuścizny literackiej Czykałenki, która powstała w burzliwym okresie na przełomie XIX i XX wieku i składającej się z wspomnień, dziennika oraz obszernej korespondencji. O ile w przypadku dzienników udało mi się skorzystać z nowego wydania z $2004 \mathrm{roku}^{1}$, to Wspomnienia tego autora dostępne były jedynie w internecie jako wydanie emigracyjne z roku $1955^{2}$. Zakres opisywanego materiału jest dosyć szeroki. Wspomnienia obejmują lata 1861-1907, Dziennik pisany był natomiast od roku 1907 do roku 1919, z tym że w obawie przed konfiskatą autor nie prowadził go w latach 19141918, aczkolwiek spisał ów okres później w postaci wspomnień, włączonych przez wydawcę do tej edycji dziennika. Ze względu na i tak obszerny materiał pominąłem w swojej interpretacji spuściznę epistolarną. Zatem chciałbym zbadać obecność Czykałenki zawartą we wspomnieniach, którym w polskim nazewnictwie literaturoznawczym odpowiada termin „pamiętnik”, zapisach dziennika oraz strefie milczenia.

Powstaniu dzieła literackiego zazwyczaj towarzyszy określony bodziec. Postarajmy się zatem w przybliżeniu prześledzić chronologię i okoliczności napisania dokumentów osobistych Czykałenki. Zaczynające się chronologicznie wcześniej od dziennika "Wspomnienia” były pisane później. Autor nie raz skarżył się, że pisał je na emigracji, gdzie nie miał pod ręką potrzebnych materiałów, które zaginęły w czasie bolszewickiej nawały na Kijów. Doroszenko w swojej książce przypuszcza, że zaczęły już powstawać w czasie I wojny światowej w Finlandii ${ }^{3}$, gdzie autor przebywał w sanatorium obawiając się

1 Ye. Chykalenko, Shchodennyk, Tempora, Kyiv 2004.

2 Ye. Chykalenko, Spohady 1861-1907, UVAN, New York 1955. Książka dostępna pod adresem: https://diasporiana.org.ua/memuari/1755-chikalenko-ye-spogadi-1861-1907/ [data dostępu 12.12.2020]

${ }^{3}$ D. Doroshenko, Yevhen Chykalenko, yoho zhyttia i hromadska diialnist, Vydannya Fondu im. Ye. Chykalenka pry Ukrainskomu Akademichnomu Komiteti, 
aresztowania i zsyłki, czekających go na Ukrainie. Niemniej jednak tenże badacz biografii Czykałenki podkreśla, że większość wspomnień napisana została właśnie na emigracji w Austrii, główną zaś motywacją pracy nad tą książką były względy zarobkowe. Wspomnienia ukazały się w latach 1925-1926 we Lwowie w spółce wydawniczej „Diło”, Dziennik natomiast już po śmierci autora w 1931 roku w wydawnictwie „Czerwona Kałyna”.

Próbując zastosować zaproponowany przez Małgorzatę Czermińską schemat interpretacyjny trójkąta autobiograficznego ${ }^{4}$, widzimy, że dokumenty osobiste Czykałenki prawie bez reszty sytuują się po stronie świadectwa. Zdarzeniowość jest ich najważniejszym aspektem, znaczną rolę w nich odgrywają opisy wydarzeń historycznych, których autor był bezpośrednim świadkiem. Lektura Dzienników niejako może uzupełniać czytanie Wspomnień, pełniących rolę bardziej oficjalnej książki, która ukazała się za życia autora. Wyznanie, czyli elementy dziennika intymnego pojawiają się niezwykle rzadko. Właśnie w zapiskach dziennika autor mógł sobie pozwolić na większe wyeksponowanie własnego ,ja”, na przykład na kąśliwe i uszczypliwe uwagi pod względem pisarzy, z którymi przyszło mu współpracować w ramach wydawanej przez siebie gazety „Rada”. We Wspomnieniach warty przytoczenia jest natomiast fragment o ataku nerwowym, którego doświadczył autor jako młody chłopiec w pensjonacie Sokołowskiego w Odessie, rozpoczynający świadomą edukację w duchu ukraińskiego patriotyzmu. Wtedy zaczął marzyć o odrodzeniu ukraińskiej państwowości na czele $z$ hetmanem ${ }^{5}$. To dobitnie potwierdza przypuszczenie, że wspomniany tekst powstawał na emigracji, kiedy Czykałenko zaczął otwarcie sympatyzować z ruchem hetmańskim i celowo mitologizował własne dzieciństwo. Niezwykle ważnym

Prague 1934, s. 75. Książka dostępna jest pod adresem: https://diasporiana.org. ua/ukrainica/9785-doroshenko-d-yevgen-chikalenko-1861-1929-yogo-zhittya-i-gromadska-diyalnist/ [data dostępu 12.12.2020]

${ }^{4}$ M. Czermińska, Autobiograficzny trójkąt. Świadectwo, wyznanie, wyzwanie, Universitas, Kraków 2000, s. 27.

${ }^{5}$ Ye. Chykalenko, op. cit., s. 79. 
wydaje się wprowadzenie przez Czermińską kategorii odbiorcy $\mathrm{w}$ aspekcie wyzwania $\mathrm{w}$ dokumentach osobistych. Jeżeli ważnym bodźcem przy rozpoczęciu prac nad wspomnieniami był wybuch I wojny światowej, wiążące się z nim nadzieje na rychły upadek Imperium Rosyjskiego i odzyskanie niepodległości przez Ukrainę, to kontynuowanie tej aktywności na emigracji stanowiło próbę ocalenia ukraińskości, apelem skierowanym do przyszłych pokoleń, aby nie ustawali w walce o sprawę narodowościową, nawet jeżeli niekiedy mogłaby ona wydawać się sprawą przegraną.

Biografia Czykałenki owiana jest tajemniczością. Przede wszystkim zastanawia jego bierność w okresie Ukraińskiej Republiki Ludowej, gdy w okresie wydarzeń rewolucyjnych i powołania Centralnej Rady po prostu usunął się na wieś, a potem po kolei odrzucał propozycje objęcia stanowisk urzędowych. Jak zaznaczyła badaczka:

Młodsi wiekiem współcześni Czekałenka szukali odpowiedzi na pytanie: dlaczego działacz cieszący się autorytetem w ukraińskich przedrewolucyjnych kręgach usunął się z życia politycznego i społecznego w latach 1917-1918, został obserwatorem wydarzeń historycznych, a nie ich uczestnikiem. [...] Polityk [O. Szulgin] nazywał swego bohatera „człowiekiem sprzed roku 1917”, weteranem ukraińskiego odrodzenia, całkiem ukształtowanego i nieprzygotowanego do nowych realiów zrodzonych przez rewolucję. ${ }^{6}$

Zajął się tym problemem również Doroszenko, minister spraw zagranicznych hetmanatu, który osobiście w imieniu Skoropadskiego proponował mu objęcie teki ministra rolnictwa, lecz Czykałenko odmówił zasłaniając się złym stanem zdrowia i zmęczeniem ${ }^{7}$. Postarajmy się zatem rozwikłać ową tajemnicę. Ważnym aspektem Wspomnień jest literackość, przejawiająca się chociażby w kunsztownej opisowości ukraińskiej przyrody. Zwłaszcza pierwsze rozdziały tej książki czyta się jak typową prozę szlachecko-ziemiańską, niezwykle

\footnotetext{
${ }^{6}$ I. Starovoitenko, Yevhen Chykalenko ta yoho spadshchyna w ukrayinskii istoriohrafii, „Istorychni doslidzhennia v Ukraini”, Vyp. 18, 2008, s. 153. [tutaj i wszędzie dalej, o ile nie zostało podane nazwisko tłumacza, tłumaczenie własne - E.S.]

7 D. Doroshenko, op. cit., i. 83.
} 
dopracowaną pod względem formalnym, w której sporo miejsca zajmują opisy domostw, prowadzenia gospodarstwa, anegdoty z życia sąsiadów mieszkających w okolicy. Główną osią narracji jest ukazanie procesu dojrzewania młodego wrażliwego chłopca oraz jego edukacji w duchu patriotycznym. Niezwykle ważnym elementem tej książki jest jej ludomania, zjawisko dosyć rozpowszechnione wśród kultur słowiańskich na przełomie wieków. Nie tylko ukraińskiej, ale także polskiej czy rosyjskiej, ale najbliższych i najłatwiejszym do udowodnienia kontekstem byłoby dla Czykałenki ludofilstwo Lwa Tołstoja. Oficjalność, literackość i dopracowanie formalne wspomnień bardzo wyraźnie kontrastuje z prywatnością Dzienników, przejawiającą się chociażby w karykaturalnych portretach ukraińskich polityków i artystów oraz niemożnością oswojenia tragicznego karkołomnego biegu historii. Widzimy, że rewolucja oraz bestialstwo natury ludzkiej, które przy tej okazji uaktywniło się w społeczeństwach dawnego imperium, podważyło racjonalny ład i zachwiało podstawami światopoglądowymi Czykałenki. Zamiast spojrzenia na wydarzenia historyczne przez pryzmat racjonalizmu i opanowania, z którym mieliśmy do czynienia we wspomnieniach, narrator po prostu włącza do tekstu materiały prasowe - apele, odezwy, pozbawione autorskiego komentarza. Jego opisy walki o Kijów toczonych przez różne stronnictwa polityczne (Centralna Rada, Dyrektoria, hetmanat wspierany przez Niemców, Biała Gwardia, bolszewicy) napisane zostały językiem chaotycznym naocznego świadka, który właśnie otarł się o niebezpieczeństwo śmierci i brakuje im głębszej refleksji historiozoficznej, a zamiast niej mamy do czynienia z powstawaniem chorobliwych wizji geopolitycznych. Nieprzypadkowo, w okresie klęski URL i upadku ukraińskiej niepodległości Czykałenko przestaje w ogóle pisać, gdyż oznaczało to porażkę jego marzeń i idei, której służył. Swoje wrażenia $\mathrm{z}$ tego okresu nie potrafił ująć na bieżąco w postaci zapisków dziennika, lecz spisał z perspektywy retrospekcji w postaci wspomnień, aczkolwiek teksty te znacznie ustępują liryzmowi i rozlewności wcześniejszych rozdziałów pamiętników.

Odwołania do Tołstoja zwłaszcza są ważne w kontekście bierności politycznej Czykałenki w okresie rewolucyjnym. Co więcej, uważam, 
że jego odsunięcie się od polityki wpłynęła teoria „nieprzeciwstawiania się złu przemocą" pisarza z Jasnej Polany. Lata 1917-1918 dla wielu państw Europy Środkowo-Wschodniej oznaczały odzyskanie lub uzyskanie niepodległych bytów państwowych powstałych na gruzach imperium Austro-Węgierskiego lub Rosyjskiego. Było to możliwe dzięki sojuszowi wszystkich warstw społecznych, przede wszystkim inteligencji i ludu. Inaczej sytuacja wyglądała na Ukrainie, gdzie przeważająca część mas ludowych znalazła się pod wpływem zgubnych haseł bolszewickich, czego skutkiem były powszechne rabunki i grabieże. Czykałenko z przerażeniem obserwował upadek człowieczeństwa na wsi. Tak naprawdę w ocenie rewolucji najważniejszy był dla niego jej aspekt moralny i to najbardziej zbliża go do tołstoizmu. Nie uważał, że czyniąc zło można zbudować sprawiedliwy ład społeczny, jak tego się spodziewali bolszewicy. W jego przypadku kwestie ustrojowe czy nawet narodowościowe schodziły na drugi plan przed wartościami moralnymi. W tym sensie lata 1917-1919 oznaczały dla niego zagładę humanizmu. Myślę, że przesłanie Czykałenki jest niezwykle aktualne dla dzisiejszej Ukrainy, gdzie często chęć osiągnięcia zysku za wszelką cenę wywołuje patologie społeczne, takie jak korupcja, nadużycia władzy, dyskredytujące samą ideę ukraińskiej niepodległości i czyniące spustoszenie moralne.

Tych paraleli i oddziaływań tołstoizmu można znaleźć całe mnóstwo we Wspomnieniach. Pokrewieństwo z ludem spotykamy już w pierwszym rozdziale książki, w którym Czykałenko opisując swoje dzieciństwo, podkreśla, że wraz z bratem chętnie spędzał czas wśród pastuszków wypasających owce. W ogóle sporo miejsca autor poświęcił opisowi kołowrotu wiejskiego żywota, wywodzących się z niepamiętnych czasów obrzędów ludowych, młocki, siania, wesel, zimowych wieczorów. Książka ta sama w sobie stanowi cenny materiał etnograficzny, bowiem zbieranie i zapisywanie wytworów kultury ludowej było jednym z postulatów kół ukraińskiej inteligencji powstających na przełomie XIX i XX wieku. Czykałenko, podobnie jak Tołstoj dostrzegał konieczność edukacji ludu i właśnie dlatego finansował wydawanie gazety „Rada”, a także napisał i opublikował własną broszurę Rozmowy o gospodarce wiejskiej, cieszącą się 
sporą popularnością̧. Działał na rzecz ucywilizowania chłopów i przebudzenia ich świadomości narodowej:

Podczas wakacji w Pereszorach podczas niedziel czytałem dworskim parobkom Kobziarza, Marka-Wowczka itd. Gdy wujek o tym się dowiedział, zaczął złośliwie ze mnie drwić . [...] Gdy przyszło mu na myśl, że moje czytania mają związek z „wędrówką w lud” [w oryginale ros.: „хождением в народ” widzimy tutaj odwołanie do ideologii narodnictwa] to zaczął udowadniać, że grupka marzycieli nie zburzy odwiecznego ładu. ${ }^{9}$

Jak wiemy, marzeniem Tołstoja było powstanie literatury dla ludu, w tym celu zaangażował się w założenie wydawnictwa „Posriednik”, publikujące książeczki dla chłopów, które miało pierwszeństwo na wydawanie jego powieści ${ }^{10}$. Ideałem Tołstoja było pozbycie się bogactwa, którego posiadanie uważał za grzech, i rozdzielenie majątku wśród chłopów. Analogię dla tej postawy można znaleźć u Czykałenki, ponieważ jeszcze przed zapowiedzianą reformą rolną odsprzedawał za niewielką płacę ziemię chłopom w swoich majątkach w Pereszorach i Kononiwce, gdyż uważał, że potrafi we własnym zakresie zadbać o ucywilizowanie relacji na wsi i narażał się tym samym arystokratom $\mathrm{z}$ sąsiednich posiadłości, podejrzewających go o skłonności buntownicze lub wywrotowe. Oczywiście, poglądy Czykałenki można określić jako tołstoizm uzupełniony o hasła odrodzenia narodowościowego.

Jak już wspomniałem podstawową będzie opozycja między oficjalnością wspomnień i prywatnością dzienników. Dlatego te obie publikacje powinny zostać rozpatrywane razem, gdyż w sposób naturalny się uzupełniają. Wysnuwam przypuszczenie, że znaczna część

8 „Za swoje książeczki otrzymałem później od towarzystw wiejsko-rolnych dwa srebrne i jeden złoty medal. Wysiłkiem ziemskich urzędów rozeszły się one w nakładzie pół miliona egzemplarzy. Prawdę przewidział L. Padałka, że broszura o 'Czarnym parze' utoruje drogę innym książeczkom w masy ludowe”, Ye. Chykalenko, Spohady 1861-1907, s. 190.

${ }^{9}$ Ibidem, s. 95.

10 W. Szkłowski, Lew Tołstoj, przeł. R. Granas, Państwowy Instytut Wydawniczy, Warszawa 1967, s. 603. 
wspomnień została napisana przed rokiem 1917, czyli wybuchem rewolucji, i należy przyznać słuszność Doroszence, który przypuszcza, że pracę nad tą książką autor rozpoczął w Finlandii podczas I wojny światowej, gdy ukrywał się przed carskimi żandarmami, chcącymi zatrzymać go pod zarzutem kolaboracji z Niemcami i Austriakami (słynne, wymyślone przez ochrankę spotkanie na czeskim zamku w Konopisztie). Świadczy o tym jasny klarowny styl wskazujący na niezłomną wiarę w racjonalny porządek świata. Znaczące jest zakończenie pamiętników. Ostatnie rozdziały książki poświęcone zostały prawie bez reszty problemom i zabiegom związanym $\mathrm{z}$ wydawaniem codziennej ukraińskiej gazety, które stało się możliwym po manifeście cara z roku 1905 . To przejście wskazywałoby na wyczerpanie formuły obecnej formy literackiej i przejście do dzienników, które autor zaczął prowadzić wcześniej i mógł w nim nieskrępowanie wylewać swoje żale. Tutaj zaryzykowałbym stwierdzenie, że Czykałenko był artystą, który zaczął uświadamiać sobie swoje powołanie, do czego przyczyniły się ciężkie warunki życia na emigracji. Nie musiał już zajmować się gospodarstwami, które zostały znacjonalizowane na radzieckiej Ukrainie. Gdy znalazł się wobec nicości, dopiero wtedy poczuł się pisarzem, co poskutkowało intensywną pracą nad wspomnieniami, mającymi wszelkie znamiona wybitnej i genialnej książki. Wcześniej pewnym substytutem artyzmu była dla niego działalność wydawnicza i filantropia polegająca na finansowaniu ukraińskiej literatury. Prawdopodobnie posiadał umysł kontemplacyjny i dlatego nie angażował się w bieżące sprawy polityczne w latach 1917-1919.

Wszystko, co ukraińskie, zostało we Wspomnieniach opatrzone dodatnimi walorami. Jest to książka piękna i wartościowa, mająca na celu podtrzymanie wiary $\mathrm{w}$ sprawę narodową. Pozytywny jest jej narrator, będący „ja” - autobiograficznym samego autora. Jako dziecko przeżywa niemal mistyczne objawienie dotyczące odrodzenia państwowego, a potem działa na rzecz poprawy sytuacji chłopów na wsi zgodnie $\mathrm{z}$ ideami narodnickimi i tołstoizmem. W kategoriach ofiary ukazane zostały losy członków ukraińskich kółek kulturalno-oświatowych, którzy za udział w ruchu narodnickim zostali skazani na wyroki zesłania. Sam Czykałenko otrzymał wtedy jedynie 
pięcioletni zakaz wyjazdu z własnego majątku w Pereszorach, w którym miał przebywać pod nadzorem policji, ale jako osoba politycznie podejrzana nie mógł już w żadnym wypadku liczyć na przyjęcie na studia, co było jego marzeniem. Owe pamiętniki naszkicowane zostały według czarno-białego schematu, gdzie dobro lezy po stronie ukraińskości, zaś negatywną etykietą opatrzony został ustrój carski i rosyjski szowinizm, stanowiący jeden $\mathrm{z}$ jego filarów. W dziennikach natomiast te sprawy nie wydają się tak oczywiste. Oczywiście, klęskę Ukraińskiej Republiki Ludowej spowodowały głównie czynniki zewnętrzne, mianowicie inwazja Armii Czerwonej, ale poprzedzał ją rozkład moralny i anarchia, która zapanowały na Ukrainie w latach 1917-1919. Przyczyny porażki autor upatruje w ideach socjalistycznych, których zwolennicy zdominowali Centralną Radę i Dyrektorię. Zamiast flirtu z zarażonymi bolszewizmem proletariatem i wiejską biedotą ukraiński rząd powinien był oprzeć się na klasie średniej ziemskich posiadaczy („середній землевласник” - w oryginale), twierdzi autor. Lecz przyczyny klęski URL tkwią również w ukraińskiej mentalności, której choroby i bolączki bardzo dokładnie zostały przedstawione przez autora w zapiskach dziennika. Czykałenko wykładał naprawdę spore kwoty, żeby uchronić wydawaną przez siebie gazetę przed bankructwem, gdyż miała ona stosunkowo niewielką ilość prenumeratorów (poniżej czterech tysięcy). Już w zapiskach z lat 1908-1910 nie szczędzi gorzkich słów pod adresem własnego narodu, którego większość stanowią, jego zdaniem, „perewertni” - odmieńcy, zrusyfikowani Ukraińcy, bardziej nienawidzący sprawy odrodzenia narodowego niż sami Rosjanie. Jesteśmy narodem anarchistów o mentalności niewolników, zaznacza Czykałenko ${ }^{11}$. Od czasu do czasu ogarnia go manichejska wizja rzeczywistości, gdyż oskarża ukraińską inteligencję o zdradę interesów narodowych. Poszukiwał remedium w idealizacji ukraińskiej wsi, lecz jego chłopomania doznaje bolesnej porażki w okresie porewolucyjnego chaosu, gdy zaobserwował zezwierzęcenie ludu. Wtedy jedyną deską ratunku dla

11 Ye. Chykalenko, Zapys z 8 chervnia 1910 r. [w:] idem, Shchodennyk, t. 1 (19071917), s. 106. 
Czykałenki staje się idea monarchiczna i pomysł osadzenia na projektowanym ukraińskim tronie księcia obcokrajowca. Swoje poglądy na tę sprawę wyłożył w artykule „Gdzie wyjście?”, który ukazał się w gazecie „Wola” 12 . Z tą pesymistyczną wizją polemikę podjął Wiaczesław Łypyński w broszurze Powołanie „Waregów” czy organizacja włościan? ${ }^{13}$. Ową polemikę spróbowała zrekonstruować ukraińska pisarka Tania Malarczuk w powieści Zapomnienie osnutej na wątkach z biografii Łypyńskiego ${ }^{14}$. Czykałenko często się pojawia w tej publikacji, wypowiada się cytatami z własnych wspomnień i dzienników ${ }^{15}$. Widzimy, że reakcją Czykałenki na rewolucję było odrealnienie i idealizacja rzeczywistości. Wydarzenia rewolucyjne znalazły się w jego przypadku po stronie niewyrażalnego, dlatego pogrążył się na jakiś czas w milczeniu. Analogię dla takiej postawy, polegającej na całkowitym rozczarowaniu się we własnym narodzie, znajdziemy również w dziennikach rosyjskiej poetki Zinaidy Gippius, dla której z kolei jedynym ratunkiem dla Rosji był „obcy bagnet”16.

W swoim tekście próbowałem wydobyć przede wszystkim walory literaturoznawcze omawianych książek, lecz polityka, a zwłaszcza relacje międzynarodowe odgrywają w nich ważną rolę, dlatego ważne jest odwołanie się do historii idei i historiozofii, ponieważ właśnie w czynnikach zewnętrznych Czykałenko upatrywał antidotum na kryzys ukraińskiej tożsamości. Ważną rolę w dziennikach odgrywają katastroficzne przewidywania, kontrastujące $\mathrm{z}$ optymizmem wspomnień. Owe chorobliwe wizje są niewątpliwie reakcją na sytuację zagrożenia i otarcia się o śmierć w mieście, o które raz po raz

12 Idem, De vyhid? Lyst do redaktsii, Wien 1921. Książka dostępna jest pod adresem: https://chtyvo.org.ua/authors/Chykalenko_Yevhen/De_vykhid7_lyst_do_redaktsii/ [data dostępu 12.12.2020]

${ }^{13}$ V. Lypynskyi, Poklykannia variahiv chy orhanizatsiia khliborobiv? Kilka zauvah z pryvodu statti Ye. Kh. Chykalenko "De vyhid?", New York 1954.

14 T. Malarchuk. Zabuttia. Roman, Vydavnytstvo Staroho Leva, Lviv 2016, s. 203. ${ }^{15}$ Ibidem, s. 130, 201.

16 Z. Gippius, Dzienniki petersburskie (1914-1919), Dziennik warszawski (19201921), przeł. H. Chłystowski, Czytelnik, Warszawa 2010, s. 446. Zob. E. Sobol, Mesjanizm i rewolucja. Polska i Rosja w tekstach rosyjskich symbolistów - Zinaidy Gippius i Aleksandra Błoka, „Bliza”, 4 (9), 2011, s. 182-194. 
wybuchają ciężkie walki, mam na myśli oczywiście Kijów. Niektóre z nich oczywiście się sprawdziły, na przykład o podziale Ukrainy między Rosję a Polskę, niebywałej rusyfikacji, która będzie karą za chwilę narodowowyzwoleńczej euforii. Czykałenko na przykład obawia się koalicji białych z Ententą, polskiej inwazji, ale także bierze pod uwagę rozlanie się bolszewizmu po całej Europie i cofnięcie się cywilizacji do stanu pierwotnych jaskiniowców:

Gdy naprawdę bolszewizm zagarnie całą Europę, to nasza cywilizacja może zaniknąć, jak ona, zgodnie $\mathrm{z}$ doniesieniami gazetowymi, zanika teraz w Moskowszczyźnie. U nas już na wsiach wraca życie pierwotne. ${ }^{17}$

W Dziennikach Czykałenki odnotowujemy katastrofizm, pojmowany jako wrogość historii i zagładę wartości. Zamiast linearnej koncepcji dziejów zaczynają dominować odczucia irracjonalne, a także obawy o nieuchronny zanik postępu cywilizacyjnego, wizja historii jako inwazji barbarzyństwa. W tym sensie dzienniki Czykałenki niejako poprzedzają inne świadectwa krytykujące ustrój totalitarny, na przykład dokumenty osobiste lub prozę autobiograficzną Czesława Miłosza i Aleksandra Wata, które właśnie są interpretowane przez pryzmat występowania w nich problematyki moralnej i próby odpowiedzi na odwieczne pytanie: skąd zło? (łac. ubi malum?) ${ }^{18}$. Niewątpliwie, owe zagadnienie zdominowało także refleksję historiozoficzną ukraińskiego autora. Te analogie i konteksty pozwalają nam jeszcze bardziej uzmysłowić opozycję między arkadyjskością wspomnień i infernalnością dzienników Czykałenki.

Korzenie germanofilstwa Czykałenki tkwią jeszcze w okresie przedrewolucyjnym, gdy z zazdrością patrzył na rozkwit życia ukraińskiego w przynależnej do Austro-Węgier Galicji. Przeprowadzał paralelę między sytuacją wynarodowienia Ukraińców w Imperium Rosyjskim a przebudzeniem narodowym, które ogarnęło Czechów, Łotyszy i Estończyków pod niemieckim panowaniem. Tylko Niemcy

17 Ye. Chykalenko, Zapys z 1 zhovtnia 1918 r. [w:] idem, Szczodennyk, t. 2, s. 126. Ten motyw regresu cywilizacyjnego pojawia się także w dziennikach Gippius. ${ }^{18}$ M. Czermińska, op. cit., s. 88-90. 
potrafiliby uczynić z Ukraińców kulturalny naród, wyrokuje autor dzienników ${ }^{19}$. Dlatego prowadzona w 1918 roku polityka Niemców na Ukrainie wydaje mu się bardzo krótkowzroczna. Zachowują się niczym okupanci, rozbudzając $\mathrm{w}$ krótkim czasie przeciwko sobie niechęć prawie wszystkim warstw społecznych. W ogóle nie orientują się w sytuacji na Ukrainie. Nie dostrzegają wielkiej różnicy między Rosjanami i Ukraińcami, w ogóle nie dbają o ukraińskie odrodzenie narodowe. Obalając Centralną Radę o orientacji socjalistycznej, Niemcy postanowili się oprzeć ma Związku Właścicieli Ziemskich, realizującym swoje interesy klasowe, a powinni byli prowadzić politykę środka na zasadach narodowo-demokratycznych, wtedy potrafiliby zjednoczyć masy ${ }^{20}$. Widzimy zatem, że poglądy polityczne Czykałenki podczas URL i wcześniejszym okresie nacechowane były umiarem i szeroko pojętym centrowym liberalizmem, ale właśnie ta opcja najbardziej przegrała w epoce wstrząsów rewolucyjnych, gdy społeczeństwa byłego imperium podzieliły się na zwolenników rewolucji i obrońców starego ładu, a przemoc i wojna stanowiły jedyny sposób rozwiązania sporów politycznych. W sytuacji klęski ukraińskiej państwowości w jego przekonaniach zaczynają dominować czynniki utopijne. W późniejszym czasie wykonał on oczywiście zwrot w kierunku idei monarchistycznych.

Wspomnienia i Dzienniki Czykałenki są niezwykle ważne dla badań dziejów ukraińskiego czasopiśmiennictwa, ponieważ przez długi czas wydawana przez niego gazeta „Rada” była jedynym przejawem życia ukraińskiego w Imperium Rosyjskim. Bardzo szczegółowo dowiadujemy się o ówczesnych realiach związanych $\mathrm{z}$ funkcjonowaniem prasy, kłopotach z cenzurą, pracy redakcji, która wpłynęła także na jego zapiski osobiste, musiał bowiem często używać języka ezopowego czy robić przerwy w pisaniu obawiając się aresztowania.

Niewątpliwie publikacja dzieł Czykałenki jest niezwykle ważnym wydarzeniem dla ukraińskiej literatury i życia społecznego. Zawarta jest w nich czytelna przestroga skierowana do współczesnych

\footnotetext{
19 Ye. Chykalenko, Zapys z 1 chervnia 1918 [w:] idem, Shchodennyk, t. 2, s. 46. ${ }^{20}$ Idem, Zapys z 9 serpnia 1918 [w:] ibidem, s. 96.
} 
Ukraińców, aby nie popełniali błędów swoich przodków, ponieważ po klęsce URL Ukraina doświadczyła stalinowskiego ludobójstwa i polityki wynarodowienia. Ukraina musi stanowić przede wszystkim ideał moralny, zaś znalezienie się po stronie dobra jest ważnym czynnikiem w obronie ukraińskiej państwowości w dzisiejszych niełatwych czasach, gdy mamy do czynienia jak gdyby z próbą powtórzenia historii.

\section{References}

Chykalenko Ye., De Vyhid? Lyst do redaktsii, Wien 1921.

Chykalenko Ye., Shchodennyk, vol. 1 (1907-1917); idem, Shchodennyk, vol. 2 (1918-1919), Tempora, Kyiv 2004.

Chykalenko Ye., Spohady 1861-1907, Ukrainska Vilna Akademiia Nauk u SShA, New-York 1955.

Czermińska M., Autobiograficzny trójkąt. Świadectwo, wyznanie, wyzwanie, Universitas, Kraków 2000.

Doroshenko D., Yevhen Chykalenko, yoho zhyttia i hromadska diialnist, Vydannia

Fondu im. Ye. Chykalenka pry Ukrainskomu Akademichnomu Komiteti, Prague 1934.

Gippius Z., Dzienniki petersburskie (1914-1919), Dziennik warszawski (1920-1921),

przeł. H. Chłystowski, Czytelnik, Warszawa 2010.

Lypynskyi V., Poklykannya varyahiv chy orhanizatsiia khliborobiv? Kilka zauvah

z prywodu statti Ye. Kh. Chykalenko "De vyhid?", New-York 1954.

Malarchuk T., Zabuttia. Roman, Vydavnytstvo Staroho Leva, Lviv 2016

Sobol E., Mesjanizm i rewolucja. Polska i Rosja w tekstach rosyjskich symbolistów Zinaidy Gippius i Aleksandra Błoka, „Bliza”, 4 (9), 2011.

Starovoitenko I., Yevhen Chykalenko ta yoho spadshchyna w ukrainskii istoriohrafi, „Istorychni doslidzhennia v Ukraini”, Vyp. 18, 2008.

Szkłowski W., Lew Tołstoj, przeł. R. Granas, Państwowy Instytut Wydawniczy, Warszawa 1967. 
IV. Zagadnienia komparatystyki literackiej i filozoficznej 


\section{Dawid Bzorek}

University of Warsaw (Poland)

ORCID: 0000-0002-6549-2873

\section{Filip Orlik i Franciszek II Rakoczy w ujęciu porównawczym}

\section{Pylyp Orlyk and Francis II Rákóczi in comparative perspective}

\section{Abstract:}

The author of this article showed the differences between two baroque ego-documents of prominent politicians: the 'Travel Diary' of Pylyp Orlyk, hetman of Ukraine and 'Diaries. Memories 'of Francis II Rákóczi, Prince of Transylvania. In the article is shown the family and love life of both personas. An interesting point of Rákóczi's ego-documents is also his love for Elżbieta Sieniawska, carefully hidden in the pages of his ego-documents.

Keywords: II. Rákóczi Ferenc, Pylyp Orlyk, discourse, private life.

W książce „Drogi zeszycie...”, „drogi ekranie...”, Philippe Lejeune pisze:

Papier to przyjaciel. Biorąc go za powiernika, uwalniacie się od swoich emocji, nie obciążając nimi drugiej osoby. Pozwala on swobodnie dawać wyraz rozczarowaniom, wybuchom gniewu, smutkom, wątpliwościom, ale także nadziejom i radościom. ${ }^{1}$

Ego-dokumenty epoki baroku przybliżają swoim czytelnikom ogromną ilość materiału odnośnie wydarzeń tamtego okresu² oraz

${ }^{1}$ Ph. Lejeune, „Drogi zeszycie...”, „drogi ekranie...”. O dziennikach osobistych, Wydawnictwa Uniwersytetu Warszawskiego, Warszawa 2010, s. 40.

2 Więcej: V. Shevchuk, Pro mali ukrainski diiariushi yak istoryko-literaturni pamiatky [w:] Mali ukrainski diarii XVII-XVIII stolit, uporiadkuvannia, pereklad, vstupna stattia ta komentar Valeriia Shevchuka, „Klio”, Kyiv 2015, s. 7-50. 
życia ludzi. Do klasycznych ego-dokumentów zalicza się: listy, wspomnienia, autobiografie i pamiętniki.

Celem mojego artykułu jest porównanie życia rodzinnego w pamiętnikach Filipa Orlika (1672-1742) oraz Franciszka II Rakoczego (1676-1735). Aktualność problemu wynika z tego, iż danymi postaciami interesuje się liczne grono naukowców, nie tylko Ukrainy i Węgier, ale również Polski, Słowacji, Rumunii i in.

„Diariusz podróżny” był skrupulatnie pisany przez Filipa Orlika w latach 1720-1732. Oryginał dziennika znajduje się w archiwum Ministerstwa Spraw Zagranicznych Francji w Paryżu, w oddziale Mémoires et Documents. Pologne (1720), № 7, 8, 9, 10, 11. Początkową część dziennika odczytał z oryginału oraz opracował do druku Jan z Tokar Tokarzewski Karaszewicz. Publikacja dziennika ukazała się w tomie XVII „Prac Ukraińskiego Instytutu Naukowego” (seria historyczna, zeszyt 3) w roku 1936 w Warszawie. We wstępie Tokarzewski zapowiedział wydanie wszystkich pięciu tomów diariusza oraz tom szósty, zawierający biografię hetmana, szczegółowe informacje o rodzinie Orlików, zbiór dodatkowych dokumentów, rejestry oraz informacje uzupełniające poprzednie tomy. Prace nad wydaniem dzienników hetmana Orlika przerwała II wojna światowa.

Drugim analizowanym przeze mnie ego-dokumentem są „Wyznania” oraz „Pamiętniki” Franciszka II Rakoczego. ${ }^{3}$ Ich oryginalna nazwa to "L'autobiographie d'un prince rebelle. Confession et Mémoires de François II Rákóczi”. Pamiętniki o wojnie weggierskiej od 1703 do jej zakończenia zostały ukończone w 1717 r. w Grobois. Owe ego-dokumenty Rakoczego miały więcej szczęścia niż diariusz Filipa Orlika, gdyż zostały wydane po raz pierwszy już w 1739 r. w Hadze w kilkutomowym dziele Histoire des révolutions de Hongrie où l'on donne une idée juste de son légitime gouvernement. Ukazały się one w języku węgierskim w 1861 roku dzięki zgodzie cenzury austriackiej. Wyznania zostały spisane w języku łacińskim. Ich tekst został odnaleziony w $1858 \mathrm{r}$. w Bibliothèque Nationale, a wydany

${ }^{3}$ Franciszek II Rakoczy, Pamiętniki. Wyznania, opr. Jerzy Robert Nowak, Państwowy Instytut Wydawniczy, Warszawa 1988 
w języku węgierskim w 1876 r. Dziennik Filipa Orlika natomiast został napisany w języku staropolskim $\mathrm{z}$ dużą ilością makaronizmów - słów łacińskich, francuskich, starocerkiewnosłowiańskich, greckich oraz tureckich. Dodatkowo, w dzienniku znajduje się duża liczba listów w języku polskim i francuskim.

Oba ego-dokumenty, pisane przez dwóch przedstawicieli epoki Baroku, są różne, ale równocześnie podobne. Filip Orlik dzieli swój dziennik podróżny na lata, miesiące oraz dni. Pierwszym wpisem tego fragmentu jest dzień 10 października 1720 roku, a ostatnim 13 lutego 1723 roku. Ego-dokumenty Franciszka II Rakoczego są podzielone na część „Wyznania” oraz „Pamiętniki”. „Wyznania. Księga pierwsza” są datowane na lata 1676-1701, następnie są prowadzone „Pamiętniki” 1703-1711, a następnie druga księga „Wyznań” - lata 1711-1712. U Rakoczego pamiętniki nie są prowadzone jak u Orlika, gdyż są one podzielone jedynie na lata, a $\mathrm{w}$ każdym roku informacje na temat wydarzeń są podane tekstem ciągłym, niepodzielonym.

Żywoty Filipa Orlika oraz Franciszka II Rakoczego są do siebie bardzo zbliżone. Oboje byli wychowani przez matki. Dzieciństwo u nich nie było idealne, stabilne. Ojciec Orlika zginął w bitwie pod Chocimiem, kiedy Orlik nie miał nawet roku. Początkowo pobierał on nauki we wsi, w której się wychował - w szkole, która należała do monastyru bazylianów, później kontynuował edukację w Wilnie w kolegium jezuickim. Franciszek II Rakoczy urodził się w Borszy a wychował w Munkaczu (obecnie Mukaczewo - ukr. Мукачево, węg. Munkács). Jego dzieciństwo przypadło na lata, kiedy toczyły się walki o zamek w tymże mieście i finalnie jego kapitulacja. Został on w 1688 roku (Rakoczy miał wtedy 12 lat) oddzielony od całej rodziny i oddany na wychowanie do kolegium jezuickiego w Austrii. Jak sam pisze:

O Panie, widzisz, że dziś jeszcze pisząc te słowa z trudem mogę powstrzymać żałość. Doprawdy, czyż mogło coś gorszego spotkać młodego księcia? Wygnano mnie z ojczyzny, wyrwano z ramion rodziców, wysłano do nieznanego kraju, potraktowano w sposób niegodny mego urodzenia i pozostawiono $\mathrm{z}$ ludźmi o obyczajach, do których zupełnie nie byłem przyzwyczajony i których języka nie znałem. [...] Pozbawiony wszelkiej pociechy ludzkiej, szukając rady 
w mym nieszczęściu, do Ciebie zwróciłem się, Panie, Pocieszycielu strapionych i Ojcze sierot. ${ }^{4}$

Jego rówieśnik, Filip Orlik, po ukończeniu kolegium jezuickiego wraz z matką Iryną Małachowską przeprowadza się do Kijowa, gdzie zapisuje się do klasy filozoficznej w Akademii Kijowsko-Mohylańskiej. W kręgu jego zainteresowań znalazły się historia, retoryka i poetyka. Podczas nauki, Filip Orlik wykazywał talent do nauki języków. Znał m.in. staropolski, francuski, ukraiński, łacinę, turecki, co w późniejszym czasie daje swoje owoce m.in. w sposobie pisania jego dziennika. Walentyna Sobol w artykule pt. „Multikulturowy dyskurs w ego-dokumentach Filipa Orlika herbu Nowina i Karola Chojeckiego herbu Lubicz" zauważa:

Filip Orlik, władający biegle językiem polskim, spisał w nim swój cały pięciotomowy dziennik, ale sporo inkrustował swój pamiętnik, zgodnie z panującą barokową tradycją ${ }^{5}$, wyrażeniami francuskimi, tureckimi, greckimi, a najobficiej - łacińskimi. ${ }^{6}$

Franciszek II Rakoczy po ukończeniu kolegium jezuickiego zdobywał wykształcenie w Czechach, potem parę lat we Włoszech, a później, jak sam pisze, „dalsze lata strawiłem na dworze wiedeńskim, na płochych rozrywkach młodego wieku"7.

W życiu Filipa Orlika oraz Franciszka II Rakoczego ważną rolę odgrywa rodzina. Sam Orlik nie był etnicznym Ukraińcem. Jego rodzina posiadała korzenie Białoruskie, Litewskie, Czeskie, Polskie: „Jego dziadek miał korzenie czeskie, ojciec uważał się, jak sam mówił

${ }^{4}$ F. Rakoczy, Pamiętniki. Wyznania, wybrał, opracował i wstępem poprzedził J. Nowak, przełożyła M. Paczoska, PIW, Warszawa 1988, s. 61.

${ }^{5}$ J. Axer, Dyskusje o roli łaciny w Nowych Atenach Benedykta Chmielowskiego jako świadectwo republikańskiej tożsamości narodu szlacheckiego [w:] Staropolskie kompendia wiedzy, red. I. Dacka-Górzyńska, J. Patryka, Warszawa 2009, s. 42.

6 V. Sobol, Multikulturowy dyskurs w ego-dokumentach Filipa Orlika herbu Nowina i Karola Chojeckiego herbu Lubicz [w:] Stan badań nad wielokulturowym dziedzictwem dawnej Rzeczpospolitej, red. W. Walczak, K. Łopatecki, t. VI, Białystok 2013, s. 524

7 F. Rakoczy, Pamiętniki..., s. 165. 
'politycznym Polakiem', a matka pochodziła z litewsko-białoruskiego rodu." " W czasie wesela Iwana Obydowskiego herbu Sulima, Filip Orlik zaznajamia się z Hanną - córką połtawskiego pułkownika wojska zaporoskiego Pawła Hercyka. Hanna pochodziła z znanego rodu kozackiej starszyny, mającego korzenie żydowskie ${ }^{9}$. Wkrótce po spotkaniu, Filip i Hanna pobierają się. Wydawać by się mogło, że ich małżeństwo zostało zawarte tylko z rozsądku i w celu wspięcia się przez Orlika po szczeblach kariery urzędniczej. Jednakże małżeństwo było udane i Filip Orlik do końca swoich dni kochał swoją żonę. Wkrótce po ślubie urodziło się ich pierwsze dziecko, córka, jaką nazwali Anastasiją (Nastusia). Następnie na świat przyszli kolejno: Hryhir, Michał, Warwara (Barbara), Jakiw (Jakóbek), Marta, Maryna (Marija) oraz Kateryna. Na kartach „Dziennika podróżnego” Filip Orlik pokazuje jak bardzo jest przywiązany do rodziny. Skrzętnie notuje dni, w których jego dzieci obchodzą imieniny oraz informuje, że daje za nich ofiarę na mszę. Hanna na emigracji wzięła na siebie ciężar opieki nad siedmioma dziećmi, kiedy w tym samym czasie Filip próbował zbudować koalicję antyrosyjską w Europie. Nawet przeprowadza się do Wrocławia, uciekając przed szpiegami rosyjskimi. Na kartach „Diariusza podróżnego” można zauważyć, że największą osobistą tragedią dla hetmana była wiadomość od żony o śmierci syna Jakubka:

30/19 Maij [1721] w Piątek czekałem cały dzień w wielkich szagrenach na Listy z Wrocławia ktore odebrałem z poczty o siodmey godzienie y z nich informowawszy się że Żona moia naykochańsza w tak wielkich po naykochańszym synie żalach zostaiąc żyie, niezmiernie ucieszyłem się bo mi naybardziey o iey Życie szło żeby nie osierociła dzieciey $\mathrm{w}$ tak wielkim nieszczęściu y w niepewnym stanie zostaiąc. ${ }^{10}$

8 T. Chukhlib, Pro Ukrinu $z$ honorom $i$ humorom. Pylyp Orlyk, Seriia: Velyki ukraintsi, OP „Zhytomyrska obldrukarnia”, Kyiv 2008, s. 4.

${ }^{9}$ Hertsyky, Russkyi byohrafycheskyi slovar, http://www.rulex.ru/01040070.htm [08.02.2021]

${ }^{10}$ Diiarii hetmana Pylypa Orlyka, opratsiuvav do druku Jan z Tokar Tokarzewski Karaszewicz, Pratsi Ukrainskoho naukovoho instytutu, tom XVII, seriia istorychna, knyha 3, Varshava 1936, s. 49. 


\section{i dalej:}

Junij 2/Maij 21 [1721] [...] Odebrałem także Listy od Corki Moiey y od Syna Michała pisane o przyczynie smierci nieboszczyka naymilsze-o Jakubka, ktorey był przyczyną niebożny Praeceptor, gdyż on właśnie dał mu lekarstwo chleba $\mathrm{z}$ siarką y z bobkowym lisciem, y kazał napalić piec, przy ktorym siedząc zaraził sobie głowę swądem y gorącem y nabył bolenia głowy y niezwyczaynych womitow a potem Epilepsiey. ${ }^{11}$

Strata dziecka jest dla Orlika dużym ciosem, gdyż właśnie w nim widział swojego następcę. W jedynym z listów do Szwecji pisze:

Nieuleczalny ból mojego przygnębionego ducha, ból, jaki przenika całą moją istotę i przekracza wszystkie nieszczęścia, a zrodził się on ze smutnej doli, jaka spotkała mojego ukochanego syna Jakuba, jedynej mojej pociechy, choć najmłodszej wiekiem, ale najbardziej rokującym [...] dziesięcioletnim chłopcem o rzadkim i dziwnym szczęściu. Ta nieodżałowana strata męczy mnie takimi wewnętrznymi bólami, że nie chcę niczego dla siebie, nawet życia. ${ }^{12}$

Drugi książę, Franciszek Rakoczy poślubia w 1694 roku w Kolonii księżniczkę Karolinę Amalię Heską-Rheinfels. Małżeństwo doczekało się czwórki potomstwa. Karolina Amalia była jedynążoną księcia, a po jej śmierci w 1722 r., Franciszek II nie wstąpił więcej w związek małżeński.

Ciekawą kwestią ego-dokumentów Rakoczego jest również jego miłość do Elżbiety Sieniawskiej, skrzętnie ukryta na kartach jego ego-dokumentów. Elżbieta Helena Sieniawska z Lubomirskich była żoną Adama Mikołaja Sieniawskiego herbu Leliwa, hetmana wielkiego koronnego. Spotkanie tych dwojga miało miejsce 24 grudnia 1701 r. w Warszawie. Jerzy Robert Nowak we wstępie do „Pamiętników. Wyznań” zwraca uwagę, że „Elżbieta Sieniawska, z domu Lubomirska, była zarazem największą miłością księcia Rakoczego i główną organizatorką pomocy militarnej i finansowej dla jego powstania"13. Dalej pisze:

11 Ibidem, s. 50.

12 A. Yensen, Orlyk u Shvetsii, „Zapysky Naukovoho tovarystva imeny Shevchenka”,

t. XCII, kn. VI, Lviv 1909, s. 109.

13 F. Rakoczy, Pamiętniki..., s. 15. 
Sieniawska pomagała Rakoczemu w nawiązaniu szerszych kontaktów z różnymi wpływowymi postaciami życia politycznego w Polsce, stworzyła mu w swych włościach stosunkowo bezpieczne warunki przetrwania najtrudniejszych dni do czasu wybuchu powstania na Węgrzech. ${ }^{14}$

Miłość Elżbiety Sieniawskiej i Franciszka II Rakoczego znalazła swoje odbicie m.in. w listach pisanych w języku francuskim. Z czasem miłość Franciszka przemijała, jednakże romans dalej był kontynuowany dla dobra Węgier. W pewnym momencie książę przenosi się do Gdańska, gdzie prowadzi hulaszcze, beztroskie życie. Skutkuje to końcem romansu między Franciszkiem II Rakoczym i Elżbieta Sieniawską.

Filip Orlik w czerwcu 1714 r. wyrusza z rodziną do Szwecji, gdzie przebywał przez pięć lat i gdzie narodziła się jego córka Maryna. Później 11 października 1720 r. wyruszył w podróż przez Niemcy, Austrię, Czechy, Polskę, Mołdawię, Rumunię, Bułgarię, Macedonię, Grecję, aż ostatecznie osiadł w Hospodarstwie Mołdawskim.

W dalszych częściach „Dziennika podróżnego” można znaleźć wiele listów miłosnych hetmana do swojej małżonki. Jednakże są to listy opublikowane jedynie częściowo w oryginale bądź przepisywane i dodawane do dziennika „dla pamięci”15. W dzienniku z lat 17201723 znajdujemy jedynie wzmianki o korespondencji:

18/7 [1723] [...] Eodem rano idąc do Cerkwi na nabożeństwo odesłałem do Alexandra Greczyna wspomnione-o tu w tym Diariuszu kilkakrotnie, Listy moie pisane [...] do Żony Moiey naymilszey, do Nastusi y Hrehore-o, dzieciy moich kochanych 13/2 Januarij praesentis $1723[\ldots]^{16}$

14 Ibidem, s. 16.

15 Więcej: V. Sobol, Piękno listów miłosnych staropolskich i staroukraińskich (Jana Sobieskiego i Pilipa Orlika) [w:] Epistolografia $w$ dawnej Rzeczypospolitej, red. P. Borek, M. Olma, Biblioteka tradycji, nr CXLVIII, tom VI: Stulecia XVI-XIX. Nowa perspektywa historyczna i językowa, Collegium Columbinum, Kraków 2015, s. 121-128.

16 Diiarii hetmana Pylypa Orlyka, opratsiuvav Jan z Tokar Tokarzewski Karaszewicz, Pratsi Ukrainskoho naukovoho instytutu, tom XVII, seriia istorychna, knyha 3, Varshava 1936, s. 163. 
Do końca swoich dni Filip Orlik kochał swoją żonę. Niestety, nie są znane dalsze losy Hanny. $\mathrm{W}$ dokumentach można jedynie znaleźć informację, że wraz z Filipem przebywała ona w Hanowerze, a następnie we Wrocławiu. Nie jest znana data i miejsce jej śmierci?.

W powyższym artykule zaakcentowany został jedynie urywek dyskursu życia prywatnego Filipa Orlika oraz Franciszka II Rakoczego. W dalszej perspektywie moim zdaniem najciekawszym jest dalsze, głębsze zbadanie życia prywatnego tych dwóch wybitnych osobistości w perspektywie komparatystycznej.

\section{References}

Axer J., Dyskusje o roli łaciny w Nowych Atenach Benedykta Chmielowskiego jako świadectwo republikańskiej tożsamości narodu szlacheckiego [w:] Staropolskie kompendia wiedzy, red. I. Dacka-Górzyńska, J. Patryka, Warszawa 2009.

Chukhlib T., Pro Ukrainu $z$ honorom i humorom. Pylyp Orlyk, Seriia: Velyki ukraintsi, „Zhytomyrska obldrukarnia”, Kyiv 2008.

Diiarii hetmana Pylypa Orlyka, opratsiuvav do druku Jan z Tokar Tokarzewski

Karaszewicz, Pratsi Ukrainskoho naukovoho instytutu, tom XVII, seriia istorychna, knyha 3, Warsaw 1936.

Lejeune Ph., „Drogi zeszycie...”, „drogi ekranie...”. O dziennikach osobistych, Wydawnictwa Uniwersytetu Warszawskiego, Warszawa 2010.

Rakoczy F., Pamiętniki. Wyznania, wybrał, opracował i wstępem poprzedził Jerzy Robert Nowak, przełożyła Maja Paczoska, Państwowy Instytut Wydawniczy, Warszawa 1988.

Shevchuk V., Pro mali ukrainski diiariushi yak istoryko-literaturni pamiatky [w:] Mali ukrainski diarii XVII-XVIII stolit, uporiadkuvannia, pereklad, vstupna stattia ta komentar Valeriia Shevchuka, „Klio”, Kyiv 2015, s. 7-50.

Sobol V., Multikulturowy dyskurs w ego-dokumentach Filipa Orlika herbu Nowina $i$ Karola Chojeckiego herbu Lubicz [w:] Stan badań nad wielokulturowym dziedzictwem dawnej Rzeczpospolitej, red. W. Walczak, K. Łopatecki, t. VI, Białystok 2013, s. 515-529.

Sobol V., Piękno listów miłosnych staropolskich i staroukraińskich (Jana Sobieskiego i Pilipa Orlika) [w:] Epistolografia w dawnej Rzeczpospolitej, red. P. Borek, M. Olma, Biblioteka tradycji, nr CXLVIII, tom VI: Stulecia XVI-XIX. Nowa perspektywa historyczna i językowa, Collegium Columbinum, Kraków 2015, s. 121-128. Yensen A., Orlyk u Shvetsii, „Zapysky Naukovoho tovarystva imeny Shevchenka”, t. XCII, kn. VI, Lviv 1909, s. 93-169. 


\title{
Oleksandr Siedin
}

National University of "Kyiv-Mohyla Academy" (Ukraine)

ORCID: 0000-0001-9943-8907

\section{Revealing the Rationality of Myth: Contribution of Bronislaw Malinowski}

\begin{abstract}
:
The article is focused on the intellectual significance of the theory of myth developed by prominent Polish anthropologist Bronislaw Malinowski within his anthropological approach known as functionalism. The author argues that Malinowski already in the first half of the 20th century anticipated the main trend within the later studies on myth. Like many influential myth-theorists of the next generations, Malinowski recognized the elements of rationality within mythical thinking. Both his emphasis on the integrity of culture as well as his opposition to diffusionism and evolutionism resonate with the perspective of structuralists in the second half of the 20th century. According to Malinowski, myth and science as the parts of culture serve mainly for the basic biological needs of the human body. The more elaborated vision of the functionality of myth has been proposed later in the philosophy of mythology of German poststructuralist Hans Blumenberg. Despite that, Malinowski's attention to the function of myth reflected and formed the general tendency of contemporary science of myth. This tendency presupposes the "de-archaization" of myth in contrast to the progressivist vision of myth as entirely "irrational" or "paralogical" thinking. The author also analyses how the intellectual heritage of Malinowski is used in the recent studies made by contemporary Polish and Ukrainian scholars.
\end{abstract}

Keywords: myth, rationality, Malinowski, functionalism, culture, anthropology.

The recent change in the theory of myth (second half of the 19th - early 21st century) which followed Bronislaw Malinowski's (1884-1942) works justifies the significance of the research of his studies in modern times. There is a certain number of tendencies in the philosophy of mythology of the latest decades that can be determined. 
Firstly, structuralists contributed to the rational methodological approach in myth theory. The complex schemes of myth elements that distinguish binary oppositions in Claude Lévi-Strauss ${ }^{1}$ methodology and linguistical perception of myth by Roland Barthes ${ }^{2}$ reflect this tendency.

Secondly, the function of myth came to the foreground. It was crucial to study the function in order to trace back the origins of myth and how the mythical itself was preserved throughout time. The emphasis on function therefore led to the increase of rationality in the perception of myth and through this also reduced the opposition of the "mythical" and the "rational" in modern approaches. Hans Blumenberg ${ }^{3}$, a poststructuralist, stated that mythical and scientific thinking have always been interconnected. The idea of the rational functionality of myth and its role in forming significances for societies, both regarding abstract and specific things, has been studied by Chiara Bottici ${ }^{4}$ and William Doty ${ }^{5}$.

Thirdly, the source material in the field of myth theory has expanded considerably, mostly due to the ethnographic expeditions conducted in the 20th century that continued to contribute to our understanding of indigenous peoples all around the world. Moreover, the striking use of imaginary narrative by the Nazi drew public attention to the modern political manifestation of the mythical.

All these tendencies grew stronger and became more distinctive after Malinowski's death. Reference to Malinowski's heritage is beneficial due to the fact that he already combines all the above listed features of modern studies. He was an ethnographer and anthropologist himself, and his field research of indigenous peoples brought him recognition. Moreover, he developed a method of classification of culture elements with a help of complex tables. His work laid

${ }^{1}$ C. Lévi-Strauss, Anthropologie structurale, Librairie Plon, Paris 1958, p. 227-255.

2 R. Barthes, Mythologies, Editions du Seuil, Paris 1957, p. 179-233.

${ }^{3}$ H. Blumenberg, Arbeit am Mythos, Suhrkamp, Frankfurt am Main 1979.

${ }^{4}$ C. Bottici, A Philosophy of Political Myth, Cambridge University Press, NY 2007.

${ }^{5}$ W. G. Doty, Mythography. The Study of Myths and Rituals, The University of Alabama Press, Tuscaloosa and London 2000. 
the foundation for a functionalist direction in anthropology that proclaimed the primary rationality of archaic societies in general and the utilitarian functions of myth in particular. Malinowski was one of the first researchers to view the Nazi phenomenon through a lens of anthropology, going as far as calling it "modern magic"6. Therefore, Malinowski's approach resembled the next-generation perspective on myth much more than it reflected the theories of many of his contemporaries, for example, the theories of the proponent of the irrationality of mythical (paralogical) thinking Lucien Lévy-Bruhl (1857-1939) ${ }^{7}$. The current article aims to determine the key aspects of Malinowski's functional approach in the context of the philosophy of mythology and to compare the reception of his contribution in modern Poland and Ukraine.

In his studies, Malinowski followed another prominent anthropologist's work "The Golden Bough" by a British scholar James George Frazer (1854-1941). This work became an inspiration for the young researcher to study anthropology himself. ${ }^{8}$ He appreciated Frazer's ideas throughout his whole life even though their ideas were in theoretical opposition. For example, as opposed to Frazer, Malinowski denied the enlightenment's view on myth as a primitive pre-scientific stage of spiritual life evolutionally transformed into rational thinking.

In addition, his anthropology model features the clearly articulated theoretical opposition in regard to contemporary theories of his time, namely the very influential ones, diffusionism and evolutionism. ${ }^{9}$ He strongly disagreed with the idea that cultural practices in societies emerge as a result of historical borrowing

${ }^{6}$ B. Malinowski, Freedom and Civilization, Roy Publishers, New York 1944.

${ }^{7}$ L. Lévy-Bruhl, La mythologie primitive: le monde mythique des australiens et des papous (Nouv.éd.), Presses universitaires de France, Paris 1963.

8 B. Malinowski, Myth in primitive psychology [in:] Magic, Science and Religion and Other Essays, ed. R. Redfield, The Free Press, Glencoe, Illinois 1948, p. 72-73.

9 A. I. Richards, The Concept of Culture in Malinowski's Work [in:] Man and Culture. An Evaluation of the Work of Malinowski, ed. R. Firth, Routledge \& Kegan Paul, London 1960, p. 15-32. 
or mark a certain basic stage in the process of evolution. On the contrary, he was interested in the cause of the cultural element's interconnection with different elements, their functions and how they formed a whole. When an observer is deeply involved in cultural context, according to Malinowski, it turns out that the ritual which may appear senseless at first sight and seemingly illogical myth have specific pragmatic functions in the life of society. This perspective resonates with the structuralism approach which takes over in humanitarian studies several decades later. Thus, back in the 1920s, Malinowski and Radcliffe-Brown ${ }^{10}$ introduced a perspective that revolutionized the perception of culture itself, representing its whole through the functioning balance of its compounds. Although, it was partially a result of the influence of structural functionalistic ideas of Emile Durkheim.

The fundamental idea of Malinowski's work is viewing culture as an integrated whole. By 'whole' he understands a complex of means of production, as well as means of consumption, the rules of interpersonal interactions and the common social practices like reproduction of ideas, beliefs and customs. As Malinowski wrote:

Whether we consider a very simple or primitive culture or an extremely complex and developed one, we are confronted by a vast apparatus, partly material, partly human and partly spiritual, by which man is able to cope with the concrete, specific problems that face him. These problems arise out of the fact that man has a body subject to various organic needs, and that he lives in an environment which is his best friend, in that it provides the raw materials of man's handiwork, and also his dangerous enemy, in that it harbors many hostile forces. ${ }^{11}$

Subsequently, Malinowski suggests that primarily culture emerges from the basic biological needs of a human being such as warmth, food, reproduction, hygiene, health, safety etc. An artificial environment,

10 A. R. Radcliffe-Brown, The Andaman Islanders, The University Press, Cambridge 1922.

${ }^{11}$ B. Malinowski, A Scientific Theory of Culture and Others Essays, Oxford University Press, New York 1960, p. 36. 
in other words, culture, has to be built in order to satisfy these needs. As the researcher underlines, this "secondary, or artificial environment, has to be permanently reproduced, maintained, and managed"12. Malinowski, therefore, determines that new restrictions and needs emerge inside the culture itself. He names this process a "secondary type of determinism". Malinowski distinguishes between instrumental and integral imperatives. The instrumental imperatives emerge out of economic, normative, educational and political types of activity, while integral ones include knowledge, religion and magic. In fact, Malinowski terms as functional the analysis that defines the relationship between cultural performance and a human need, basic or derived.

In this case, the need that was conveniently satisfied within the system serves as a foundation for culture itself, and not, in any case, the bare fact of a certain historical intervention or innovation that might have happened. Malinowski puts a spotlight on the satisfied need and proves that it is this need that causes those cultural changes that set the assimilation process of a certain historical innovation into motion. The scholar also connects the phenomenon of cultural diversity to the regional specifics of the needs which may be transformed in correlation to the universal and the fundamental manifestations of humanity. ${ }^{13}$

Science and myth thus both serve the same purpose: the satisfaction of integral imperatives. Malinowski suggests a simple understanding of science as an attempt to utilize past experiences in order to achieve certain results in the future, to implement the theory into practice and to make use of it bending reality to one's will. Science, due to the researcher, in that sense had been long present in primitive technology, economic and social structures since the very beginning of humanity's intellectual journey as "homo sapiens, homo faber and homo politicus" 14 . Malinowski assumes that the disappearance

\footnotetext{
12 Ibid., p. 37.

13 Ibid., p. 38-41.

14 Ibid., p. 10.
} 
of science for at least one generation would push back the primitive society to its animal origins or, more likely, such a society would cease to exist at all. ${ }^{15}$

Myth fulfils the overall social pragmatical function. Malinowski's anthropological field studies prove that it is unproductive to view myths as merely articulated and written narratives, they should be determined according to their manifestation, in other words, according to the way different societies experience them.

The fundamental functionality of myth is manifested through vital cultural practices in social, ritual and ethical aspects. Thus, this distinguishes myth from science and philosophical allegories. Myth does not explain something and does not inform about the past historical events or express the boldness of human imagination. Indigenous peoples use other narratives and means of communication like scientific knowledge, folktales, legends, which Malinowski also attentively analyses. Myth, if considered as a part of a culture, is no longer a tale but reality. It determines the way of life, strengthens and encodes beliefs, justifies the ritual, represents the social code and moral principles. ${ }^{16}$

Besides the rituals, customs and social structures themselves include the myth references and are regarded as results of some mythical events. Malinowski emphasizes that "the cultural fact is a monument in which the myth is embodied"17. Hence, in scholar's opinion, the myths determine and exert control over many cultural features and form the "dogmatic backbone of primitive civilization". In this regard, there is no difference between primitive and modern societies. Much to Malinowski's surprise, the determinative role of myth in social subordination, rituals, moral codes and institutions that has remained unchanged till the present day went unnoticed

15 Ibid., p. 10-11.

16 B. Malinowski, Myth in primitive psychology [in:] Magic, Science and Religion and Other Essays, ed. R. Redfield, The Free Press, Glencoe, Illinois 1948, p. 74-89.

17 Ibid., p. 85. 
by anthropologists of the West, even though Christianity has always shared common traits with indigenous myth systems. ${ }^{18}$

However, the biological factor is the basis for Malinowski's functionalist theory. The need that transfer the mythical to the real is a secondary one and only has a purpose to maintain the kind of culture that is able to satisfy the basic human needs. In this case, the specific features of a human become vague and culture itself is regarded merely as a complicated and long way (in comparison to the animal instincts) of achieving the aforementioned biological goals. Blumenberg was the one to humanize the functionalism of myth. In his opinion, myths are the only guiding lights in the world where there is a lack of instincts and the abyss of reality appears incomprehensible. Notably, Malinowski also defined myth as a reference point that determines the significance of things.

The Ukrainian scientific discourse has long acknowledged Malinowski's work as a classic. His work is regarded as the foundation of functionalism, however, is rarely deeply analysed. The limited available bibliography sources currently leave us with two perspectives of reception of Malinowski's works in Ukraine: 1) a brief summary of the key aspects of his studies ${ }^{19}$, particularly in regard to myth ${ }^{20} ; 2$ ) the partial implementation of his ideas for more extensive research.

It has to be expected that more insightful studies of Malinowski's work emerge in Poland, his motherland even though the scholar's career is most tightly associated with foreign countries. He spent a few years at the University of Leipzig and went on to head the Department of Anthropology of the London School of Economics (1927). From the beginning of World War II until his death in 1942, he lived in the United States, where he taught at Cornell and Yale

18 B. Malinowski, Myth as a Dramatic Development of Dogma [in:] Malinowski and the Work of Myth, ed. I. Strenski, Princeton University Press, Princeton, New Jersey 2014, p. 117-128.

19 O. Hinda, Skarbnytsia svitovoi antropolohichnoi dumky: teoretychni postulaty Bronislava Malinovskoho, „Pedahohichna dumka”, nr 1, 2010, s. 74-76.

${ }^{20}$ I. Frys, Mifolohichni kontseptsii XX st.: ohliad problemy, „Kyivski polonistychni studii”, t. 19, 2012, s. 377-382. 
universities. However, the future outstanding anthropologist was born in 1884 in Krakow. It was there that he received his education (first at the Jan Sobieski Secondary School, later at the University of Krakow) and his first doctorate (for research in physics and mathematics, in 1908; Malinowski received his second doctorate in anthropology in London in 1916). ${ }^{21}$

A big step towards increasing the visibility of Malinowski's studies was made when the book "Malinowski between Two Worlds: the Polish Roots of the Anthropological Tradition"22 was published. The book was dedicated to the celebration of 100 years since the researcher's birth and was the result of the collaboration between Polish and British anthropologists. The introduction was written by Malinowski's daughter Helena Wayne. For the first time, the Polish period of the researcher's life was described in detail revealing the origins of his intellectual journey. Krzysztof J. Brozi ${ }^{23}$ from Maria Curie-Skłodowska University also refers to the processes that took place at the turn of the 19th and 20th centuries in academic circles in Krakow in his work on the origins of the teachings of B. Malinowski. Brozi notes that in the days of Malinowski's youth there was a variety of philosophical ideas, from positivism, empiriocriticism, neo-Kantianism, Darwinism, Hegelianism, Aristotelianism up to the philosophical teachings of the Far East. Stefan Pawlicki, a historian of philosophy, who was interested in the culture of the ancient East and cognitive theories, the influential representative of empiriocriticism Wladyslaw Heinrich, and the positivist Maurycy Straszewski, can be considered Malinowski's mentors. According to Brozi, the theoretical framework of these researchers

${ }^{21}$ R. Firth, Introduction: Malinowski as Scientist and as Man [in:] Man and Culture. An Evaluation of the Work of Malinowski, ed. R. Firth, Routledge \& Kegan Paul, London 1960, p. 1-15.

22 R. Ellen, E. Gellner, G. Kubica, and J. Mucha, eds, Malinowski between Two Worlds: The Polish Roots of an Anthropological Tradition, Cambridge University Press, New York 1988.

${ }^{23}$ K. Brozi, Philosophical Premises of Functional Anthropology, "Philosophy of the Social Sciences", nr 22(3), 1992, p. 357-369. 
specifically influenced the development of Malinowski's ideas. In a collective monograph on the concept of law by Malinowski ${ }^{24}$, the first part is also devoted to justifying the influence exerted on his views by such Polish intellectuals as Stanislaw Estreicher and Dragun Latur.

While working at Jagiellonian University, Petr Skalnik ${ }^{25}$ researched the role of philosophy in Malinowski's intellectual biography. He came to the conclusion that religion, ethics, politics and, above all, cultural aspects of Malinowski's ideas have their origins in philosophical theories. At the same time, B. Malinowski defended a certain autonomy of anthropology from philosophy. In contrast to philosophy, anthropology, in his opinion, was meant to adhere to the empirical data collected in field research.

In the context of mythology studies, the most attention is paid to Malinowski's view of myth as a living cultural force ${ }^{26}$, including his critique of the textual analysis of the perception of magic by the indigenous people, without taking into account their own cultural practices. ${ }^{27}$ Malinowski's concept of the function of myth is considered to be one of the central points of his functionalism. ${ }^{28}$ In particular, his remark about the correlation between the role of myth in the life of indigenous people and the role of the Bible in Christian culture is further observed. ${ }^{29}$ It is worth noting that Malinowski's

24 Bronislaw Malinowski's Concept of Law, ed. M. Stępień, Springer, 2016.

25 P. Skalnik, Malinowski and Philosophy [in:] Philosophy and Anthropology. Border Crossing and Transformation, ed. A. K. Giri, J. R. Clammer, Anthem Press, London/New York 2013, p. 167-183.

${ }^{26}$ M. Ples, Swiadomość mityczna jako problem filozoficzny, „IDEA - Studia nad strukturą i rozwojem pojęć filozoficznych", XXIV, 2012, s. 5-18.

${ }^{27}$ M. Rakoczy, Słowo magiczne jako działanie - o kilku walorach koncepcji Bronisława Malinowskiego, „Poznańskie studia slawistyczne”, nr 4, 2013, s. 151-163.

${ }^{28}$ M. Mazurkiewicz, The Types, Interpretations and Functions of Myth, „Respectus Philologicus", nr 22(27), 2012, p. 45-56.

${ }^{29}$ M. M. Boużyk, Dlaczego mit? Kilka uwag w świetle filozofii klasycznej [w:] Tożsamość w ezoterycznych nurtach kultury, red. A. Świerzowska, I. Trzcińska, LIBRON, Kraków 2016, s. 9-25. 
contribution is implemented in further studies of Melanesian myths ${ }^{30}$, within which he lived and carried out most of his fieldwork.

The way that modern researchers utilize Malinowski's ideas to strengthen their own positions in discussions on several current issues is of particular interest. For example, his idea of myth as an integral part of culture serves as a starting point of a chapter in research on mythological elements in the narratives of the transgender transition. ${ }^{31}$ The rehabilitation of non-European cultural traditions proposed by Malinowski and his thesis on cultural equality proved to be useful in the context of combating xenophobia during the European migration crisis, which also affected Poland. ${ }^{32}$ At the same time, Malinowski's emphasis on the idea of cultural integrity, as well as his critique of the integration of the indigenous people, were used as an argument in favour of homogeneous Polish nation-building. ${ }^{33}$ The critique of economical rationality in the perception of human proposed by Malinowski in his analysis of the non-utilitarian symbolic ritual exchange among indigenous people proved to be effective in the unmasking of modern mythology ${ }^{34}$, in particular the myths of the consumer society ${ }^{35}$. It is also noteworthy that in the study on

${ }^{30}$ F. M. Rosiński, Funkcja mitu, opowiadania i bajki w kulturze krajowców Melanezji, „Colloquia Anthropologica et Communicativa: Mit, prawda, imaginacja”, t. 3, 2011, s. 61-78.

31 A. M. Klonowska, S. Bonvissuto, Personal and Collective Trans-Mythologies: Creative Attitudes to Gender Incongruence Among Transgender Individuals, "Creativity Studies", 2019, nr 12(1), p. 61-74.

32 D. Baumgarten-Szczyrska, K. Milewska, D. Obalek, Spotkanie z innym jako przykład edukacji globalnej w przestrzeni muzeum, „Muzealnictwo”, nr 58, 2017, s. 227-239.

33 J. Szacki, Polish Sociology and Problems of Nation Building [in:] National Survival in Dependent Societies: Social Change in Canada and Poland, ed. R. Breton, G. Houle et al, McGill-Queen's University Press, Montreal 1990, p. 71-82.

34 M. Napiórkowski, Mitologia współczesna, Wydawnictwa Uniwersytetu Warszawskiego, Warszawa 2013.

35 R. Rogoziecki, Konsumpcja jako mit społeczeństwa postindustrialnego. O Baudrillardowskim pojęciu konsumpcji, „Przegląd Socjologiczny”, t. 64, nr 3, 2015, s. $27-51$. 
mythological narratives formed around the death of John Paul II the views on myth proposed by Malinowski are also present. ${ }^{36}$

Thus, Poland is characterized by a comprehensive study of Malinowski's ideas with a remarkable emphasis on his intellectual origins. Therefore, he is widely referred to and acknowledged in different modern discourses. However, it seems that there is a gap in understanding of his heritage as a step into general revealing the rationality of myth in philosophical trends of the 19th and 20th centuries. ${ }^{37}$

There were countless attempts to draw attention to the reason in myth made by different scholars before Malinowski, for instance in the large-scale system of the philosophy of mythology introduced by Friedrich Schelling ${ }^{38}$, which was later developed by Ernst Cassirer in his "Philosophy of Symbolic Forms" 39 . However, Malinowski seems to become the first researcher who managed, having experienced the role of myth in the everyday life of indigenous societies, to deeply grasp the idea of myth as a rational way of exploring the world. His work changed the way we perceived the archaic societies and proved their way of thinking, which seemed irrational and "paralogical" to us before, to be completely rational. In this regard, Malinowski went a step further than his authoritative teacher Fraser.

In 1951, Willard Quine, one of the prominent representatives of analytical philosophy, came to a stunning conclusion in one of his most famous works "Two Dogmas of Empiricism". He revealed that the physical objects are comparable, epistemologically, to the Homeric gods and "both enter our conception only as cultural

${ }^{36}$ M. Hodalska, Śmierć Papieża, narodziny mitu, Wydawnictwo Uniwersytetu Jagiellońskiego, Kraków 2010.

${ }^{37}$ See more elaboration on the extension of limits of the rationality in the philosophy of mythology of the 19th and 20th centuries: O. Siedin, Shchodo reabilitatsii mifu ta rozshyrennia mezh rozumnoho u filosofskii dumtsi XIX-XX st., „Naukovi zapysky NaUKMA. Filosofiia ta relihiieznavstvo”, t. 3, 2019, s. 76-84.

${ }^{38}$ F. W. Schelling, Philosophie der Kunst, Cotta, Stuttgart 1859.

39 E. Cassirer, Philosophie der symbolischen Formen. Zweiter Teil: Das mythische Denken, Wissenschaftliche Buchgesellschaft, Darmstadt 1994. 
posits" 40 . So, they act as convenient mediators between thinking and experience. Quine also noted that he, being a "qua lay physicist", believed in physical objects, and not in Homeric gods, for the reason only that the former reflects the material of experience more effectively. However, Quine qualitatively equated the mythical and scientific worldview. Thus, the opposition between mythical and rational thinking was further reduced in analytical tradition as well. In the modern philosophy of mythology, the ideas about the rational functionality of myth are successfully developed and an inclusive research horizon is formed, which is based on the methodology developed by various scientific disciplines and takes a variety of manifestations of the mythical into account. ${ }^{41}$ Malinowski is of great interest nowadays, as he made a unique anthropological contribution to the general tendency of rehabilitation of myth and its inclusion in the rational (on the contrary to the progressive-educational guidelines that prevailed in the science of myth of the 19th century).

\section{References}

Barthes R., Mythologies, Editions du Seuil, Paris 1957, p. 179-233.

Baumgarten-Szczyrska D., Milewska K., Obalek D., Spotkanie z innym jako przykład edukacji globalnej w przestrzeni muzeum, „Muzealnictwo”, nr 58, 2017, s. 227-239. Blumenberg H., Arbeit am Mythos, Suhrkamp, Frankfurt am Main 1979.

Bottici C., A Philosophy of Political Myth, Cambridge University Press, NY 2007. Boużyk M. M., Dlaczego mit? Kilka uwag w świetle filozofii klasycznej [w:] Tożsamość w ezoterycznych nurtach kultury, red. A. Świerzowska, I. Trzcińska, LIBRON, Kraków 2016, s. 9-25.

Brozi K., Philosophical Premises of Functional Anthropology, "Philosophy of the Social Sciences", nr 22(3), 1992, p. 357-369.

Cassirer E., Philosophie der symbolischen Formen. Zweiter Teil: Das mythische Denken, Wissenschaftliche Buchgesellschaft, Darmstadt 1994.

40 W. V. O. Quine, Two Dogmas of Empiricism, "The Philosophical Review", vol. 60, no 1,1951, p. 41.

${ }^{41}$ See more about inclusive approach to the definition of myth.: O. Siedin, Definitsiia mifu: u poshukakh inkliuzyvnoho pidkhodu, „Naukovi zapysky NaUKMA. Filosofiia ta relihiieznavstvo", t. 4, 2019, s. 58-66. 
Cassirer E., The Myth of the State, Yale Univ. Press, New Haven 1946.

Doty W. G., Mythography. The Study of Myths and Rituals, The University of Alabama Press, Tuscaloosa and London 2000.

Ellen R., Gellner E., Kubica G., and Mucha J., eds, Malinowski between Two Worlds: The Polish Roots of an Anthropological Tradition, Cambridge University Press, New York 1988.

Firth R., Introduction: Malinowski as Scientist and as Man [in:] Man and Culture. An Evaluation of the Work of Malinowski, ed. R. Firth, Routledge \& Kegan Paul, London 1960, p. 1-15.

Frys I., Mifolohichni kontseptsii XX st.: ohliad problemy, „Kyivski polonistychni studii", t. 19, 2012, s. 377-382.

Hinda O., Skarbnytsia svitovoi antropolohichnoi dumky: teoretychni postulaty Bronislava Malinovskoho, „Pedahohichna dumka”, nr 1, 2010, s. 74-76.

Hodalska M., Śmierć Papieża, narodziny mitu, Wydawnictwo Uniwersytetu Jagiellońskiego, Kraków 2010.

Kajfosz J., Mitologie Rolanda Barthes'a a antropologia kognitywna [w:] Imperium Rolanda Barthes'a, red. A. Grzegorczyk, A. Kaczmarek, K. Machtyl, Wydawnictwo Naukowe Uniwersytetu im. Adama Mickiewicza, Poznań 2016, s. 95-106.

Klonowska A. M., Bonvissuto S., Personal and Collective Trans-Mythologies: Creative Attitudes to Gender Incongruence Among Transgender Individuals, “Creativity Studies", 2019, nr 12(1), p. 61-74.

Lévi-Strauss C., Anthropologie structurale, Librairie Plon, Paris 1958, p. 227-255.

Lévy-Bruhl L., La mythologie primitive: le monde mythique des australiens et des papous (Nouv. éd.), Presses universitaires de France, Paris 1963.

Malinowski B., A Scientific Theory of Culture and Others Essays, Oxford University Press, New York 1960, p. 36.

Malinowski B., Freedom and Civilization, Roy Publishers, New York 1944.

Malinowski B., Myth as a Dramatic Development of Dogma [in:] Malinowski and the Work of Myth, ed. I. Strenski, Princeton University Press, Princeton, New Jersey 2014, p. 117-128.

Malinowski B., Myth in primitive psychology [in:] Magic, Science and Religion and Other Essays, ed. R. Redfield, The Free Press, Glencoe, Illinois 1948, p. 72-89.

Mazurkiewicz M., The Types, Interpretations and Functions of Myth, „Respectus Philologicus", nr 22(27), 2012, p. 45-56.

Napiórkowski M., Mitologia współczesna, Wydawnictwa Uniwersytetu Warszawskiego, Warszawa 2013.

Ples M., Swiadomość mityczna jako problem filozoficzny, „IDEA - Studia nad strukturą i rozwojem pojęć filozoficznych", XXIV, 2012, s. 5-18.

Quine W. V. O., Two Dogmas of Empiricism, "The Philosophical Review”, vol. 60, no 1,1951, p. 20-43. 
Radcliffe-Brown A. R., The Andaman Islanders, The University Press, Cambridge 1922

Rakoczy M., Słowo magiczne jako działanie - o kilku walorach koncepcji Bronisława Malinowskiego, „Poznańskie studia slawistyczne”, nr 4, 2013, s. 151-163.

Richards A. I., The Concept of Culture in Malinowski's Work [in:] Man and Culture. An Evaluation of the Work of Malinowski, ed. R. Firth, Routledge \& Kegan Paul, London 1960, p. 15-32.

Rogoziecki R., Konsumpcja jako mit społeczeństwa postindustrialnego. O Baudrillardowskim pojęciu konsumpcji, „Przegląd Socjologiczny”, t. 64, nr 3, 2015, s. 27-51.

Rosiński F. M., Funkcja mitu, opowiadania i bajki w kulturze krajowców Melanezji, "Colloquia Anthropologica et Communicativa: Mit, prawda, imaginacja”, t. 3, 2011, s. 61-78.

Schelling F. W., Philosophie der Kunst, Cotta, Stuttgart 1859.

Siedin O., Definitsiia mifu: u poshukakh inkliuzyvnoho pidkhodu, „Naukovi zapysky NaUKMA. Filosofiia ta relihiieznavstvo", t. 4, 2019, s. 58-66.

Siedin O., Shchodo reabilitatsii mifu ta rozshyrennia mezh rozumnoho u filosofskii dumtsi XIX-XX st., „Naukovi zapysky NaUKMA. Filosofiia ta relihiieznavstvo", t. 3, 2019, s. 76-84

Skalnik R., Malinowski and Philosophy [in:] Philosophy and Anthropology. Border Crossing and Transformation, ed. A. K. Giri, J. R. Clammer, Anthem Press, London/New York 2013, p. 167-183.

Stepien M., Bronislaw Malinowski's Concept of Law, Department of Sociology of Law Jagiellonian University, Krakow 2016.

Szacki J., Polish Sociology and Problems of Nation Building [in:] National Survival in Dependent Societies: Social Change in Canada and Poland, ed. R. Breton, G. Houle et al, McGill-Queen's University Press, Montreal 1990, p. 71-82. 


\section{Uliana Baran}

Vasyl' Stus Donetsk National University (Ukraine)

ORCID: 0000-0002-2902-321X

\section{The development of children's literature in Ukraine in the XX-XXI centuries}

\section{Abstract:}

After Ukraine's independence in 1991 Ukrainian children got wider access to the translations of the works of prominent world writers for children. The classic literature of the world, aiming to mediate the children's feelings for beauty and literary aesthetic, became an integral part of the Ukrainian educational system. Thanks to the increase of famous children's books written in modern Ukraine, Ukraine is now experiencing the growth of a new generation of more intelligent and capable citizens free from communism ideology, able to integrate and positively contribute to the modern multicultural world.

However "children and war" is now again among the painful topics in modern Ukrainian society but not new in history and literature. There are no wars, initiated by Ukrainians. The Famine of Ukrainians in the East of Ukraine by Russians, the Second World War, physical genocide of Ukrainian families and their children for the whole century even also just for the Ukrainian language saved Pain and Distrust in the generation memory of Ukrainians.

But the aim of this survey of the Ukrainian literature for children and youth is to show the developing processes in the society on the basics of the main ideas, topics, directions and values during the XX-XXI centuries, beginning since the end of the XIX century by such prominent writer like Ivan Franko.

Keywords: Ukrainian children's literature, Ukrainian literature for children and youth, values.

The aim of my survey of the Ukrainian literature for children and youth is to show the developmental processes in it within the historical (colonial and post-colonial) context, to explicit the difference of literature paradigms under historical circumstances, for instance, 
Soviet ideology, to compare trends in depicting a child and childhood in Ukrainian and Western European literature for children and youth of the same period, as well as to emphasize the change of direction in modern literary works for children and youth in Ukraine.

The Soviet-era came into the history of Ukrainian children's literature as the period of long-lasting dependence on the ideology of communism. The children's literature back then played a role in forming the cult of Soviet childhood ${ }^{1}$.

Ukrainian children literature of the XX-XXI centuries has been reviewed in the past by Emilia Ohar who analyzed the sources collected by Olexander Ivanchenko ${ }^{2}$. These sources include literature published by the most popular publishing companies in Ukraine. For example, every year the publishing house "Veselka" (Kyiv) publishes near 240-250 book titles with a total number of copies being over 40 million. For many years they published children novels and stories translated from 49 languages used on the territory of the Soviet Union and from 42 other world languages. The books from "Veselka" were exported into 128 countries of the world and were presented during prestigious book fairs in Moscow, Frankfurt-amMain, Chicago and other similar events.

The ideological trends of internationalization and breaking cultural borders in the culture and literature in the Soviet Union including Soviet Ukraine were somewhat similar to those in North America and the European Union after the Second World War. There was, however, the difference. While the Soviets tried to create the "cult of soviet childhood", the rest of the world was trying to create another utopian model - "world children's republic". Emer O'Sullivan explains internationalization as the process of developing the media-industry products (including literature products like

${ }^{1}$ E. Ohar, Kontraversiinist radianskoho dyskursu [w:] eadem, Dytiacha knyha $v$ ukrainskomu sotsiumi (dosvid perekhidnoi doby), Svit, Lviv 2012, s. 38-55.

2 O. Ivanchenko, Vydavnytstvo "Veselka": osoblyvosti funktsionuvannia y rozvytku (1934-2010 rr.), a dissertation abstract, Taras Shevchenko National University Press, Kyiv 2011. 
stories, novels, poems, etc.) that abase borders between American and European worlds. ${ }^{3}$ This process includes translation and adaptation for a wider international audience of the work which focuses on people or events of a specific nation or country. In terms of children's literature reintegration, we can speak today about the two most influential groups, "western region" with the exchange between English, German, French, Dutch and Scandinavian languages, and "eastern region" with the exchange between the Slavic languages (especially Russian), Hungarian, German (GDR) exchange.

Literature researcher Raisa Movchan in one of her articles titled "Literature for children and youth in the system of Ukrainian literature history in XX century"4 provides the following information. In the 1920s the translations into the Ukrainian language of the literary works of Rudyard Kipling, Mark Twain, Karel Hloucha, Ernest Thompson Seton, Jules Gabriel Verne became available for the first time. They were printed in Lviv publishing-house "The world of the child". Lviv at that time was not part of Soviet Ukraine. The Ukrainian translations of Andersen's and Brothers Grimms' fairy-tales reached the Ukrainian children only in the second half of the 1930s. The prominent works of the world literature were more available in the Russian translations, reflecting the communist strategy of promoting the Russian language while often oppressing other languages used on the territory of the Soviet Union, especially Ukrainian.

Next, we discuss the most representative Ukrainian children's writers active during the time from the end of the XIX century until the breakup of the Soviet Union in 1991. We focus on those of them who are viewed as successful writers for children and have none or minimum effect of soviet ideology and propaganda on their work.

The Ukrainians novelists Leonid Hlibov, Marko Vovchok, Yuriy Fedkovych, Ivan Nechuy-Levytsky, Olena Pchilka, Ivan Franko, Borys

${ }^{3}$ E. O'Sullivan, Kinderliterarische Komparatistik, Winter, Heidelberg 2000, s. 15. ${ }^{4}$ R. Movchan, Literatura dlia ditei ta yunatstva $v$ systemi istorii ukrainskoi literatury XX stolittia, „Literatura. Dity. Chas: Visnyk Tsentru doslidzhennia literatury dlia ditei ta yunatstva", No 1, Navchalna knyha - Bohdan, Ternopil 2011, s. 12-17. 
Hrinchenko, Maria Hrinchenko (Zahirnya), and later also the early modernists Mykhailo Kotsiubynsky, Lesya Ukrainka, Volodymyr Vynnychenko, Oleksandr Oles, Mykola Vorony, Spyrydon Cherkasenko, were the adult writers that started writing for children later in their career during the second half of XIXth century. The characteristics of the style of their writing for children include the detailed and realistic descriptions of story elements and folk pragmatism. Examples of literary work written using this style we can find in stories M. Kotsiubynskyi 'Yalynka', 'Kharytia', 'Malenkyi hirshnyk', all novels written by B. Hninchenko and 'Malenkyi Horban' by S. Cherkasenko.

At the end of the XIX century and the beginning of the XX century, the next important tendency in Ukrainian children's literature can be recognized. Authors are more inclined to breaking stereotypes, introducing new themes and characters. This is especially seen in the works of V. Vynnychenko (cycles "Namysto", "Kumedija z Kostem", "Fedjko-Chalamydnyk", "Babusyn podarunok") or Ivan Franko (fairy-tales "Koly she zviri hovoryly" (tr.: "When the animals could talk")), and the world-wide known poem "Lys Mykyta"5.

Among those writers, Ivan Franko is one of the most famous Ukrainian writers who wrote for both adults and children. He was the first one who tuned his writing with the cultural and social background of young readers even when working on the adaptation of fairy-tales from all over the world, published or never published. This special tuning is evident in all his work on retelling native Ukrainian folklore stories, adaptations of "Narodnyje russkije skazki" by Alexander Afanasyev, "Sagen und Märchen der Südslawen" by Friedrich Kraus, "Kinder- und Hausmärchen" by the Brothers Grimm, "Griechische und albanesische Märchen" by Ioan Georg von Hann, Teodor Benfejer "Pantschatantra. Fünf Bücher indischer Fabeln, Märchen und Erzählungen" and Ludwig Fritze "Pantschantra",

${ }^{5}$ I. Franko, Lys Mykita [in:] B. Kümmerling-Meibauer, Klassiker der Kinder- und Jugendliteratur: ein internationales Lexikon,. Bd. 1, J. B. Metzler, Stuttgart 1999, s. 365-367. 
textbook „der Lebensklugheit in Erzählungen und Sprüchen“, also "Tuhfat ikwam ussafa" in French translation by Harns de Tassi „Les animaux en discussion avec I'homme“ and other. ${ }^{6}$ In one of his published collection of stories, he made the following comment: "For those who want to know the origin of my fairy-tales I can tell the origin or source. But every fairy-tale I rewrote fundamentally, adapting it to the taste, understanding, and surroundings of our children, our readers" 7 . This approach made him international classic and canonic children's writer of Ukraine. His collection "Koly she zviri hovoryly" was published in English translations in the magazine "The Ukrainian Canadian" in 1947-1983 and reached also an English-German young reader thanks to the Ukrainians Diaspora. Having a very good world reputation as a writer, being the star of Ukrainian bohemia of these times, Ivan Franko managed to bring the Ukrainian children's literature up from the underground. And he did it through the contributions to not only the pedagogical "school canon" 8 but also to the international children's literature canon as discussed in the work of Bettina Kümmerling-Meibauer 9 . An example here is his excellent adaptation of brother Grimm stories that are often perceived as more realistic and attractive for contemporary international readers. Nowadays we also see his work is being successfully used in creating new literary products for children. For example, very talented young Ukrainian illustrators Romana Romanyshyn and Andrij Lesiv produced and published a picture book for children of the age $3+$ based on the story "Ripka" written by Ivan Franko in 1891. This picture book won awards and was included in

${ }^{6}$ H. Sabat, Ivan Franko i dytiacha literatura: Teoretychni problemy funktsionuvannia ta retseptsii kazok pro tvaryn, Literatura. Dity. Chas: Visnyk Tsentru doslidzhennia literatury dlia ditei ta yunatstva, No 4, Diatlyk M., Rivne 2013, s. 133.

${ }^{7}$ I. Franko, Koly shche zviri hovoryly. Kazky dlia ditei [w:] eadem, Zibrannia tvoriv u 50-ty tomakh, t. 20, Naukova dumka, Kyiv, s. 75.

${ }^{8}$ B. Kümmerling-Meibauer, Integration und Ausgrenzung: Wandel in der Bewertung von Kinderliteratur [w:] Bettina Kümmerling-Meibauer, Kinderlitaratur, Kanonbildung und literarische Wertung, Stuttgart 2003, s. 271.

${ }^{9}$ Ibidem. 
the Selection of International Children's and Youth Literature "The White Ravens 2013".

Next, we focus on the period after the era of Ivan Franko, Mykhailo Kotsiubynsky, Lesya Ukrainka, Marko Cheremshyna. In the 1920s the new political reality influenced the development of Ukrainian literature. We distinguish the literature of Ukrainian emigrants who didn't accept the soviet ideology from the literature of the writers who worked in soviet Ukraine and had to adjust to the communism realities. The known authors contributing to the literature of Ukrainian emigrants are Vynnychenko, Cherkasenko, Oles, Lepky. In what follows we focus on the writers from Soviet Ukraine.

The main topics of most soviet poems and novels for children between the 1920s and the 1960s were the celebration of Lenin's ideology and praising the prosperous and great soviet system with happy soviet children, even if many children were not happy at all and lived in the harsh conditions. Sometimes these literary works with propaganda were written in pour style and could not be well understood, yet, everyone had to know how to recite them by heart. ${ }^{10}$ So, the main allowed topics at that time were patriotism, social humanism, favouring common needs over individual needs, a friendship between soviet nations, glorifying the work focused on building communism, etc. The literary works were hardly realistic due to the need to include these ideological norms. We talk about the state of children's literature, where the main focus is not esthetic values but the ideological stamps, false pathos and falsification of reality. Examples here are novels by Natalia Zabila, Oksana Ivanenko, Dmytro Cherednychenko and poetries for children written by Pavlo Tychyna, Maksym Rylsky, Volodymyr Sosiura.

But there was another part of Ukrainian children's literature of these times written outside Soviet Ukraine. This written in exile work

10 M. Vardanian, Kotseptsiia adresata zbirky opovidan V. Vynnychenka «Namysto» u konteksti literatury dlia ditei i yunatstva» 20-kh rr. XX st., Literatura. Dity. Chas: Visnyk Tsentru doslidzhennia literatury dlia ditei ta yunatstva, vyp. 4, Diatlyk M., Rivne 2013. 
is actually recognized and accepted as the modern "school canon" today. In this part of Ukrainian literature, we can see the different paradigm and a rather realistic view of the Ukrainian child and the surrounding reality. For example, all child characters in Volodymyr Vynnychenko novels for children in the collection "Namysto"11 are part of dynamic plots which include adventures, social communications, psychological challenges, facing and resolving conflicts, including conflicts between generations. His novels include serious psychological analysis and description of the real Ukrainian social environment. They are good reads for both children and adults. Indeed, for the benefit of younger readers the texts are written in suitable clear language, often using short laconic sentences, providing a clear description of the environment and problems children were where facing these times. For adult readers, the novels bring the benefit of better understanding the children's reasoning and behaviour, and their need for the love and attention of their parents. This trend in Ukrainian literature is well summarized by the following words of Maria Nikolajeva: “...not as literature addressed to children, but as a sort of storytelling therapy for frustrated adults that had left their lovely homes, their gardens, their parents, their good friends, flowing away from the Soviet regime and missing the motherland during their whole life, hoping to come back one day but not have a real chance to get back"12.

Above trends in the Ukrainian children's literature prevailed up till the new "Khrushchev thaw" phenomenon started in the sixties when the literature and art, in general, were not as much restricted by soviet censorship as before and could focus on some new directions and topics. In the 1960s, the following new and very interesting writers in Ukraine started writing for children: Vsevolod Nestayko,

${ }^{11}$ V. Vynnychenko, Namysto: opovidannia [tekst], uporiad. Y. Y. Broiak, Veselka, Kyiv 1989, 380 s.

12 M. Nikolajeva, Growing up. The dilemma of children's literature [in:] Childrens literature as communication: the ChiLPA Project, edited by Roger D. Sell, Volume 2, Amsterdam; Philadelphia 2002, p. 112. 
Viktor Blyznets, Yevhen Hutsalo, Vasyl Symoneko, Mykola Vingranovsky, Lina Kostenko, Dmytro Pavlychko, Hryhir Tiutiunnyk, Valeriy Shevchuk, Yaroslav Stelmakhand many others. In their works, we can find the attempts to understand the child's soul and the uniqueness of childhood and adolescence. In style and genre, the children's literature trends are similar to adult's ones except in the children's literature the trend of adopting the style without multiple references to communism ideological elements is more pronounced. The new trend is more about "maintaining a myth of a happy and innocent childhood, apparently fueled by writers' nostalgic memories and bitter insights into the impossibility of returning to the childhood"13. This concept of a happy childhood in Ukraine was not, in fact, reflecting the real circumstances for soviet children living in harsh conditions of soviet reality. Interesting that this false happy childhood assertion sub-trend seems to be present in the Ukrainian children's literature even nowadays.

If we look now at the development of children's literature, for example, in Germany during the same time, we can see that all the trends and changes in the style of writing for children were made by the adult writers for whom the reason for writing included the need for the self-therapy because they were frustrated during the childhood by some family or social traumas. This is especially relevant for writers who were children during the Second World War. Indeed, German writers of that period often include psychological analysis of events typical for their childhood, for example, bad parents good child scenario, social and cultural conflicts. They proclaim the emancipation of children while leaving the parents' motivations and behaviour analysis out of the story. This may have some negative effect on the reader child who can make rather inaccurate conclusions on the importance of a good child-parent relationship and social life for a happy childhood.

The same post-war generation of Ukrainian children' writers, on the other hand, adopted a different trend. They wrote rather funny

13 Ibidem, p. 113. 
and lovely stories to make the children happy even if real life was not so easy. They were trying to analyze the mistakes from their childhood in a more positive light, showing the better possibilities to stay happy in life despite all the social and generation troubles, and encourage the reader child to be a strong character and find the good way to move towards better future.

It should be noted that the above-discussed distinction between the Ukrainian trend (depicting child life in a rather positive happy way) and the European trend (focusing more on psychological analysis of rather difficult childhood) is not sharp or obvious. Both trends were present in Ukrainian and the rest of Europe literary works.

In summary, the children's literature in this period covered many different topics and genres and contributed to many pedagogical and multidisciplinary investigations. It was the time of "growing up" of children's literature. This resulted in an expansion of the children's literature in volume, style, and topic selection. Ukrainian writers publish new fairy-tales, adventure novels, stories about school and the everyday life of children. The work written in this period became part of the modern "school canon" in the pedagogical educational system in Ukraine.

For example, the prominent Ukrainian children's writer of this period Vsevolod Nestayko explains his motivation and writing style as follows. "I became the children's writer. Why for children? - Because I wished to be back into childhood - but different childhood than I had: Funny, full of adventures, games, entertainments. This different childhood scenario is, therefore, often present in my fairy-tales and adventures novels" 14 . His most popular trilogy "Toreadory z Vasjukivky"15 is the first modern Ukrainian adventure story. It is still being read and appreciated by millions of young readers. This work is about

\footnotetext{
14 T. Vorobets, Khudozhnia svoieridnist trylohii Vsevoloda Nestaika «Tereadory $z$ Vasiukivky", Literatura. Dity. Chas: Visnyk Tsentru doslidzhennia literatury dlia ditei ta yunatstva, Vyp. 2, Navchalna knyha - Bohdan, Ternopil 2012, s. 70-77.

15 V. Nestaiko, Toreadory z Vasiukivky, Veselka, Kyiv 1973.
} 
the everyday adventures of happy children, it avoids any focus on or even mentioning of the grey and sad aspects of real life in the Soviet system. This type of writing is characterized by Maria Nicolajeva as "a symbolic depiction of a maturation process so that it is not a strict accurate reflection of existing reality. The content that was written and marketed for children and young people focuses on a particular phase in a childhood-to-adulthood transition, with ethos ranging from an ideal harmony (Arcadia, Paradise, Utopia, idyll), with different degrees of departure from it, to some mission that may either succeed or fail" 16 . Indeed, Vsevolod Nestayko succeeded in creating the "primal harmony" of the virtual "idyll" of childhood, which is something children of Ukraine actually needed and still need. Interesting that communist authorities of Ukraine blamed author for creating "anti-pedagogic" influence on the soviet children. ${ }^{17}$ However, after the proclamation of the independence of Ukraine in 1991, he became a fully appreciated writer of classic children's literature. His trilogy has been adapted by the author to reflect new social realities of Ukrainian children in the multicultural world and was later re-edited by the Ukrainian publishing house "ABABAHALAMAHA". The final edition of the trilogy has 461 pages and includes integrated genres like epistolary (written letters, notices), songs that reflect Ukrainian history, legends that help the reader to better understand the original mentality and religious background of characters. Prominent German literature investigator Bettina Kümmerling-Meibauer ${ }^{18}$ recognizes the following most important aspects of the contribution of Vsevolod Nestayko to the modern canon of Ukrainian children's literature: internationality, a mix of genres, and development and widening of the existing traditional canon. These are the three aspects of the "processed canon"19. The

${ }^{16}$ M. Nikolajeva, op. cit., p. 112.

17 V. Kostiuchenko, Literaturnymy stezhkamy. Narys ukrainskoi literatury dlia ditei XX stolittia, K. I. S., Kyiv 2009, s. 201.

${ }_{18}$ B. Kümmerling-Meibauer, Kinderlitaratur, Kanonbildung und literarische Wertung, Stuttgart 2003.

${ }^{19}$ Ibidem, s. 277. 
trilogy "Toreadory z Vasjukivky" written in an excellent style for children of age 10 and higher, obtained many national and international awards and prizes.

Comparing the historical development of children's literature in Ukraine and Western Europe, one can recognize the limited impact on Ukrainian literature of the typical story-telling trends established in Western Europe at the beginning of the XIX century. This was changed after Ukraine's independence in 1991 when Ukrainian children get wider access to the translations of the works of prominent world writers for children, including the Brothers Grimm, Hans Christian Andersen, Wilhelm Hauff. The classic literature of the world, aiming to mediate the children's feeling for beauty and literary aesthetic ${ }^{20}$, became an integral part of the Ukrainian education system. Thanks to the increased access to the world's famous children's books from all over the world started in the young country almost 50 years later than in Europe and America, Ukraine is now experiencing the growth of a new generation of more intelligent and capable citizens free from communism ideology, able to integrate and positively contribute to the modern multicultural world.

For such one young reader in Ukraine are writing also Galina Malyk and Zirka Menzatjuk. In their works (about Chornobyl "Zlochynci z paraleljnoho svitu" - "Criminals from the parallel world" in humoristic-sarcastic style by Galina Malyk or about the collapse of the Soviet Union from the perspective of a twelve-yearold girl from the West of Ukraine in the novel "Jak ja rujnuvala Imperiju" - "How I ruined the Empire"), - we can follow the modern combination of old literary tradition from Hryhir Tiutiunnyk, Volodymyr Rutkivskyi and humoristic and easiness from Vsevolod Nestayko. Memories of the war, disaster but still life gladness and eternal human values are the main intentions. But even in the newest science-fiction novels "Soulary" and "Powder from dragons bones" written by a very young fantast for adolescence Volodymy Arenev we can find how gentle and philosophically he tries to show a fair of

${ }^{20}$ Ibidem, s. 271. 
the new war by the adults from the generation of the Second World War and not acceptation of the disasters of the war by the children in modern Ukraine, who are playing in the war with the toy soldiers or even recognizing the new one.

A good example of how the new generation has grown up, how the democratic and free mental activity and life gladness of young Ukrainian people were broken again from the side of Russia (Maidan and the War of 2014) is the world-known picture book "The War that Changed Rondo" made by Ukrainian illustrators Romana Romanyshyn and Andriy Lesiv (Agrafka Studio, "Vydavnyctvo Staroho Leva"):

The town called Rondo was unique. The air was clear and transparent as if woven from the thinnest light. All of its unusual and gentle residents grew flowers, nourished gardens and parks, built peculiar houses, spoke to birds and plants, loved to sing, draw and write poetry. They all enjoyed living in Rondo. Still, the three friends Danko, Zirka and Fabian loved the town the most. Everyone in Rondo knew them. [...] Rondo was famous for its wonderful flowers. The pride and beauty of the town was a large greenhouse located on the central square. It contained a collection of rare flowers and plants from the furthest parts of the planet. The strangest of all was that these flowers could sing. Concerts often took place in the greenhouse. The top venue was a vocal performance of Mozart's rondo [...] It was an ordinary day in Rondo. The residents rushed about with their usual business. Danko was heading to his friends, as he knew that Zirka just returned from her travels and had lots of new stories and drawings. The sun was shining, the flowers and birds were singing. Everything was as usual... Suddenly all became quiet. Then, a wary whisper spread around: the WAR is coming to our town. ${ }^{21}$

In their book Romana and Andij are idealistically showing at the end how it is possible with the lights and all-together to win the war:

The brighter the light and the louder the anthem, the quicker the War disappeared, along with the darkness and prickly black flowers. The whole town was singing the anthem until all the black flowers disappeared and the obscurity dissolved completely. This was a VICTORY! [...] The residents of Rondo

${ }^{21}$ R. Romanyshyn, A. Lesiv, Viina, shcho zminyla Rondo, Vydavnytstvo Staroho leva, Lviv 2015, s. 2, 8-9, 11-13. 
slowly rebuilt the town and reconstructed the greenhouse, where new flowers grew and now sing the anthem every morning just as before.

Unfortunately, it is impossible to renew everything. The transparent body of Danko still has a web of cracks near his heart, the edges of Zirka's wings remained burnt, and Fabian is limping on the pricked leg. The residents of the town changed. Each of them has sorrowful memories of the War that changed Rondo forever. Now, there are also many red poppies growing all around the town. ${ }^{22}$

Poppy is an international symbol of commemorating the fallen during the war, beginning with 1914.

"Children and war" is now again the most painful topic in modern Ukrainian society but not new in our history and literature. There are not wars, initiated by Ukrainians. The Famine of Ukrainians in the East of Ukraine by Russians and oppressions of Ukrainians by Polls in West, the Second World War, physical genocide of Ukrainian families and their children for the whole century even also for the Ukrainian language till 1991 saved Pain and Distrust in the generation memory of Ukrainians. The war caused again by Russia: orphans, strangers, death, fear and untruth are the real feelings of the Ukrainians again and are becoming the new themes in the modern Ukrainian literature for children and youth.

But in conclusion, to say the development of global culture with an interlacing of various world economic systems which is followed and served by new media and other modern communicative and information technologies disorder of political borders, the growing voluntary mobility of individuals and also resettlements of the people caused by war, poverty or political repressions opens more and more widely space multicultural communication. It also provides a variety of subjects, the conflicts and brings to the origin of new cultural identities in each separate nation which interlacing realizes a modern international canon of children's literature based on the child-centric concept.

22 Ibidem, s. 31, 33-35. 


\section{References}

Baran U., Aktyvnyi kanon suchasnoi literatury dlia ditei ta yunatstva: Zakhid ta Skhid [w:] „Naukovi pratsi: naukovo-metodychnyi zhurnal”, Vyp. 227. T. 239. Filolohiia. Literaturoznavstvo, ChDU im. Petra Mohyly, Mykolaiv 2014, s. 8-12.

Franko I. J., Mykita L., Kümmerling-Meibauer, Bettina: Klassiker der Kinder- und Jugendliteratur: ein internationales Lexikon, pub. Weimar: Metzler, Stuttgart 1999, Bd. 1.

Franko I., Koly shche zviri hovoryly [w:] Kazky dlia ditei, Zibrka Tvoriv: U 50-ty tomakh, Naukova dumka, Kyiv 1979, T. 20.

Ivanchenko O., Vydavnytstvo "Veselka": osoblyvosti funktsionuvannia i rozvytku (1934- 2010 rr.), avtoreferat dys.. ... kand. nauk iz sotsialnykh komunikatsii, Kyivskyi natsionalnyi universytet im. T. Shevchenka, Instytut zhurnalistyky, Kyiv 2011.

Kachak T., Tendentsii rozvytku ukrainskoi prozy dlia ditei ta yunatstva pochatku XXI st., Akademvydav, Kyiv 2018.

Kostiuchenko V., Literaturnymy stezhkamy. Narys ukrainskoi literatury dlia ditei XX stolittia, «K. I. S.», Kyiv 2009.

Kümmerling-Meibauer B., Integration und Ausgrenzung: Wandel in der Bewertung von Kinderliteratur [in:] Kümmerling-Meibauer, Bettina. Kinderlitaratur, Kanonbildung und literarische Wertung, Stuttgart 2003.

Kyzylova V., Khudozhnia spetsyfika ukrainskoi prozy dlia ditei ta yunatstva druhoi polovyny XX stolittia, DZ "LNU imeni Tarasa Shevchenka", Luhansk 2013.

Movchan R., Literatura dlia ditei ta yunatstva $v$ systemi istorii ukrainskoi literatury XX stolittia, Literatura. Dity. Chas: Visnyk Tsentru doslidzhennia literatury dlia ditei ta yunatstva, Vyp. 1, Navchalna knyha - Bohdan, Ternopil 2011.

Nestaiko V., Toreadory $z$ Vasiukivky, Veselka, Kyiv 1973.

Nikolayeva M., Growing up. The dilemma of children's literature [in:] Children's literature as communication: the ChiLPA Project, edited by Roger D. Sell, Volume 2, Amsterdam-Philadelphia 2002.

O'Sullivan E., Statusrelevante Funktionen von Kinderliteratur [in:] Kinderliterarische Komparatistik, ed. Emer O'Sullivan, pub. Winter, Heidelberg 2000

Ohar E., Kontraversiinist radianskoho dyskursu [w:] Dytiacha knyha v ukrainskomu sotsiumi (dosvid perekhidnoi doby), red. Emiliia Ohar, Svit, Lviv 2012.

Romanyshyn R., Lesiv A., Viina, shcho zminyla Rondo, Vydavnytstvo Staroho Leva, Lviv 2015

Sabat H., Ivan Franko i dytiacha literatura: Teoretychni problemy funktsionuvannia ta retseptsii kazok pro tvaryn, Literatura. Dity. Chas: Visnyk Tsentru doslidzhennia literatury dlia ditei ta yunatstva, Vyp. 4., Diatlyk M., Rivne 2013. 
Vardanian M., Kotseptsiia adresata zbirky opovidan V. Vynnychenka "Namysto" u konteksti literatury dlia ditei i yunatstva 20-kh rr. XX st., Literatura. Dity. Chas: Visnyk Tsentru doslidzhennia literatury dlia ditei ta yunatstva, Vyp. 4., Diatlyk M., Rivne 2013.

Vorobets T., Khudozhnia svoieridnist trylohii Vsevoloda Nestaika "Tereadory $z$ Vasiukivky, Literatura. Dity. Chas: Visnyk Tsentru doslidzhennia literatury dlia ditei ta yunatstva, Vyp. 2, Navchalna knyha - Bohdan, Ternopil 2012.

Vynnychenko V., Namysto: opovidannia, uporiad. Y. Y. Broiak, Veselka, Kyiv 1989. 
V. Ad fontes 


\section{Valerii Zema}

National Academy of Sciences of Ukraine (Ukraine)

ORCID: 0000-0003-4771-3393

\section{Wizjonerstwo historyczne w tekstach pisarzy innowierczych}

\section{Historical Visionary in the Writings of Dissident Authors}

\section{Abstract:}

This article reviews the creation and the roots of two historical legends about the trip of Ivan Smera to Alexandria and the privilege of Alexander Macedon to Slavs. The methodology of current research is based on the comparison of historical narratives. Two versions of the legend about the trip to the Orient were composed on the ground of old Kyivan chronicle which narrates the story about the choice of religion by Kyivan prince Volodimer in the last decades of the Xth century when several ambassadors were sent to study the peculiarities of Judaism, Islam, Latin and Byzantine Christianity. During the second half of the XVI century, a new version of this tale was composed by Calvinists in Polish-Lithuanian Commonwealth. It narrates the visit of a certain person (Jolash or Ivan Smera) who arrived at Alexandria in North Africa to investigate the customs of the local Christian community. Ivan Smera found that the customs and the rite of the local community reflect the ideals of simple Christian service, without icons and church decoration. The rite of this religious community responds to the customs and the service of Calvinism. Smera has reported about the customs of Alexandria's Christians to Volodimer but the Kyivan price ignored the ambassador's notes and accepted Christianity in the byzantine rite.

The other legend, which circulated in East and Central Europe during the Renaissance, narrates about the privilege of Alexander Macedon that was inscribed by golden letters on the tables in Alexandria. This imagined document relates that Slavic tribes arrived from the lands of Illyria and Dalmatia under the rulership of chieftains Lech, Roxolan, and Czech. It seems that both legends are rooted in Alexandria because Arianism prevailed in this city during late antiquity and Calvinism leaders supposed to establish good relations with orthodox patriarchs 
of this city in the second half of the XVI century. Religious life in ancient Alexandria was treated by the authors of the legend about the trip to North Africa as an example of perfect Christianity.

Keywords: the Renaissance, the Reformation, Antiquity, Calvinism, historical legend, falsification, Rus'.

Wraz z renesansowym powrotem ku źródłom i wzorom antycznym, na Litwie i w Koronie pojawiły się dzieła o charakterze historycznym i etnograficznym. Na pozór ekstrawaganckie fabuły tworzyły bogatą starożytną przeszłość dla lokalnych grup etnicznych, a wraz z rozwojem reformacji powstały też opowieści o charakterze konfesyjnym. W tym artykule zwrócę uwagę na kształtowanie się wyimaginowanej „nowej przeszłości” na przykładzie legend autorów-ewangelików, którzy zwracali uwagę na przeszłość swoich prawosławnych sąsiadów. Metodologia tego badania jest oparta na komparatystycznym zestawieniu tekstów o charakterze narracyjno-historycznym.

Jeden $\mathrm{z}$ najbardziej znanych utworów o charakterze fantastycznym jest historia rzekomego listu Połowca Iwana Smery z Aleksandrii, fabuła której jest oparta na narracji starożytnych ruskich kronik w części, która przedstawia historię o „poszukiwaniu wiary”. Dzięki przeróbce tej opowieści wyznawcy kalwinizmu próbowali zdobyć własną odległą przeszłość. Oryginalna opowieść o „poszukiwaniu wiary” powstała na kartach dawnej „Powieści minionych lat” jeszcze na początku XII wieku. Według opowieści, książę kijowski Włodzimierz Światosławowicz, wysłał ambasadorów w różne kraje świata w celu odnalezienia lepszej wiary. Ambasadorowie po powrocie opowiadali o osobliwościach islamu, judaizmu, chrześcijaństwa bizantyjskiego i łacińskiego.

Druga legenda, wpływy której moim zdaniem można postrzegać w liście Iwana Smery, powstała w obliczu poszukiwania starożytnych korzeni Słowiańskich ludów zamieszkałych na ziemiach dawnej Rzeczpospolitej. Ta legenda o przywileju Aleksandra Macedońskiego współtworzyła „nową przeszłość” dla etnicznych grup, której wersję przedstawił autor $\mathrm{z}$ grona twórców Rzeczypospolitej Babińskiej 
Stanisław Sarnicki w swoich „Rocznikach Polskich” (Annales Polonorum, 1587).

Tworzenie legend etnicznych w Europie Środkowej i Wschodniej trwało w warunkach powstania podobnych legend w Europie Zachodniej, więc Stanisław Sarnicki, Stanisław Orzechowski lub Maciej Stryjkowski mieli poprzedników, za jednego z których można uznać benedyktyna Jana Tritemiusza (1462-1516), który tworzył swoje legendy etniczne w kontekście pojawienia się idei miliastycznych. Według Anthoniego Graftona, ten zakonnik był zaangażowany w tworzenie etnicznej mitologii dla cesarza Maksymiliana Habsburga i Franków. Benedyktyn po raz pierwszy spotkał się z władcą w 1505 r., kiedy panujący nie miał ani stolicy, ani znacznego zamku, ale mógł „kapitalizować” przeszłość swoich przodków, bo poszukiwał korzeni dynastii burgundzkiej i Habsburgów w antycznej Troi. W tym samym czasie Albrecht Dürer przedstawił „Bramę Honoru” - łuk triumfalny zaprojektowany w celu potwierdzenia pochodzenia przodków cesarza z Egiptu, a Hartmann Schedel uważał za przodka Franków ostatniego władcę Troi - Priama. ${ }^{1}$ Wreszcie w 1514 r. Tritemiusz opublikował historię Franków, opierając swoje pismo na pracach domniemanego autora, który żył w 500 r., za panowania Chlodwiga, króla, który zjednoczył wszystkie plemiona Franków i został ochrzczony jako katolik. Według Graftona, schemat Tritemiusza był prosty: Frankowie przybyli do Bawarii, skąd wypędzili aborygenów, którzy zachowywali się jak zwierzęta, jedząc żołędzie. Benedyktyn twierdził, że posiada nadludzkie zdolności, a magia i nauka są ze sobą nierozerwalnie związane. Pisał historię jakby pod dyktando aniołów, tak jak jego starożytni poprzednicy. ${ }^{2}$

List z Aleksandrii do księcia Włodzimierza jest przykładem poszukiwania „konfesyjnej ojczyzny”. Podobnie jak Chlodwig, książę kijowski zjednoczył plemiona ruskie i został ochrzczony, co tworzyło przestrzeń do fantazji dla pisarzy czasów odrodzenia. Opowieść

\footnotetext{
${ }^{1}$ A. Grafton, Worlds Made By Words: Scholarship and Community in the Modern West, Cambridge 2011, p. 71.

2 Ibidem, p. 77.
} 
o poszukiwaniu odpowiedniej wiary stała się dobrą okazją dla autorów-ewangelików. List Połowca Iwana Smery, który powstał prawdopodobnie w drugiej połowie XVI wieku, tworzył „nową przeszłość” ewangelików; ta opowieść zachowała się w dwóch wersjach (polskiej i łacińskiej). Ogólnie rzecz biorąc, wierni Kościołów reformowanych zwracali się ku przeszłości dla poszukiwania alternatywnego, własnego doświadczenia i uzasadnienia własnego wyznania. Według Bruce’a Gordona, liczne publikacje „źródeł chrześcijaństwa” - pism Ojców Kościoła - miały wielki wpływ podczas reformacji. Gordon zwraca uwagę na to, że wyznawcy Kościołów reformowanych aktywnie, chociaż nie bez brzytwy Ockhama, poszukiwali dzieł i biografii ich rzekomych "proroków” - Augustyna, Bernarda z Clairvaux, Jana Husa, Savonaroli. Pojawienie się przeszłości wyznań reformowanych przejawiało się w pisaniu dzieł polemicznych, które miały obalić oskarżenia o schizmę, wysunięte przez ortodoksów, a poprzedni męczennicy służyli przykładem i zainspirowali walkę o własne miejsce wśród innych wyznań ${ }^{3}$.

List Smery dotarł do nas w dwóch podobnych wersjach, zawartych w pracach polskich ewangelików: starsza wersja mieści się w książce Andrzeja Lubienieckiego (rękopis z lat 1612/13), zaś druga jest związana z publikacją Andrzeja Węgierskiego (ukazała się drukiem w 1652 r., powtórzona w 1679 r.). W tej historii „wyboru wiary” dodano wzmianki o Aleksandrii jako miejscu, w którym istnieje odmiana chrześcijaństwa, niby bliska kalwinizmowi. Niemal detektywistyczna historia znalezienia i utraty rękopisu zawiadamia, że oryginalny list Połowca Smery, który odwiedził starożytne centrum chrześcijaństwa i opisał zwyczaje chrześcijan, w tajemniczy sposób zniknął. Wydawca jego kopii, socynianin Christopher Sand (16441680), napisał, że „pożyczył” informacje o autorze z zaginionej kroniki Stefana Budzyńskiego (1590). Według Budzyńskiego, oryginał znalazł kiedyś w pobliżu Starego Sambora diakon z Witebska Koźma

${ }^{3}$ B. Gordon, The Changing Face of Protestant History and Identity in the Sixteenth Century [in:] Protestant History and Identity in Sixteenth-Century Europe, Vol. 2: The Later Reformation, Aldershot 1996, p. 13. 
Kołodyński, przetłumaczył na język polski i wysłał do Budzyńskiego. Georgij Golenchenko uważa, że Szymon Budnyi również wspomniał o liście Smery ${ }^{4}$. Friedrich Bock twierdził, że Benedykt Wiszowaty (zm. 1704 r.) znalazł przesłanie w rękopisie swojego współwyznawcy Jana Jakuba Hryniewicza Trembickiego (1597-1678) i nadrukował w wersji łacińskiej w załączniku do historii kalwinisty Andrzeja Węgierskiego (1678). ${ }^{5}$ Opierając się na fakcie, że starzec Artemij, który uciekł z Moskwy na Litwę, ponieważ głosił poglądy sprzeczne z panującym Iosyflanstwem, wspominał heretyckie przemówienia Koźmy lub Andrzeja w Witebsku w 1562 r., badacze próbują utożsamić „wolnomyśliciela” z Koźmą Kołodyńskim, co powinno służyć potwierdzeniu historyczności tej postaci, a także prawdziwości przesłania Połowca Smery z Aleksandrii. ${ }^{6}$

Iwan Franko uważał, że list mógł pochodzić z kręgu antytrynitariuszy, więc jego autorem najprawdopodobniej był sam Stefan Budzyński. Genezę legendy o wzorowej strukturze wspólnoty chrześcijańskiej, o której zawiadamia list Smery, Franko widział w legendzie Księdza Jana, króla abisyńskiego, który ogłosił idealną strukturę państwa, a w wyprawach krzyżowców Franko widział impet dla historii legendarnego Księdza Jana ${ }^{7}$. Laura Ronchi sugeruje, że list Smery został napisany przez kalwinistów ${ }^{8}$, ponieważ jego osobliwością jest faktyczne uznanie filioque, a pod tym względem prawosławni zasadniczo różnią się od wyznawców Kościołów

${ }^{4} \mathrm{G}$. Golenchenko, Ideinye i kulturnye swiazi wostocznosławianskih narodow w XVI - seredine XVII w., Minsk 1989, s. 112-124.

${ }^{5}$ J. Tazbir, Falsyfikat w stużbie propagandy różnowierczej [w:] Kościół, społeczeństwo, kultura: Prace ofiarowane profesorowi Wiesławowi Müllerowi z okazji pięćdziesięciolecia pracy naukowej i dydaktycznej, Lublin 2004, s. 31-32.

${ }^{6}$ I. Maliszewskij, Podlożnoje pismo polowca Iwana Smery $k$ welikomu kniaziu Władimiru Swiatomu, Kiew 1876, s. 67; G. Golenchenko, Idejnye i kulturnye swiazi wostochnosławianskih narodow, s. 113.

7 I. Franko, Studii na poli karpatoruskoho pysmenstwa XVII - XVIII w. [w:] Zapysky NTSz, t. 41, 1901, s. 31-39.

${ }^{8}$ L. Ronchi, Predicazione riformata e ortodossia in Lituania nel 16 sec.: La Epistola di Ivan Smera sulla conversion della Russia, „Protestantismo”, An. 50, 1995, fasc. 3, p. 195-217. 
reformowanych, którzy przestrzegali katolickiej wykładni nauki o zesłaniu Ducha Świętego. ${ }^{9}$

Według legendy list (falsyfikat) Iwana Smery został znaleziony w 1567 r. przez prawosławnego diakona, a później arianina Andrzeja (Koźmę) Kołodyńskiego. Andrzej Lubieniecki (1551-1623) w swojej „Poloneutychii” twierdził, że Kołodyński był tylko tłumaczem listu na język ruski, a następnie na język polski, kopiując tekst na wniosek skarbnika koronnego Stanisława Sobka (zm. 1569). Druga łacińska wersja opowieści o podróży Smery pojawiła się dzięki publikacji Benedykta Wiszowatego, który w osobnej części „Historii Kościoła” porównał praktyki religijne chrześcijan aleksandryjskich z końca $\mathrm{X}$ wieku z naukami Jezusa. Pierwsza wersja podróży do Aleksandrii w poszukiwaniu "lepszej wiary", opisana przez Lubienieckiego, zawierała katolicki topos o szybkim upadku Cesarstwa Bizantyjskiego pod tureckimi ciosami z charakterystyczną interpretacją, zarzucając Grekam czczenie „idola” zamiast odosobnienia od papieża. Dla Lubienieckiego ważne jest również to, że starożytne świątynie chrześcijaństwa przekształcono w meczety, jak znany kościół św. Sofii w Konstantynopolu. Główną intrygą tej narracji jest to, że książę Włodzimierz Światosławowicz wysłał swojego doktora i sekretarza Jołasza (w wersji łacińskiej Iwan Smera) na ziemie „greckie” w celu zbadania lokalnej wiary i zwyczajów. Podróżując przez Węgry, Serbię i Bułgarię, Jołasz dotarł do Antiochii, Jerozolimy, a następnie Aleksandrii. Stamtąd oznajmił, że żadne z nabożeństw, ani rzymskie, ani greckie mu nie odpowiadały i dopiero w Aleksandrii podobało mu się nabożeństwo bez obrzędów ludzi biednych, cierpiących ze strony „niesprawiedliwych Greków”. Do przyjęcia tej wiary wysłannik próbował przekonać Włodzimierza Światosławowicza, ale książę zignorował propozycję; poprosił cesarza bizantyjskiego Bazylego o wydanie siostry za mąż i został ochrzczony w obrządku greckim, co odpowiada

${ }^{9}$ L. Ronchi de Michelis, Eresia e riforma nel cinquecento: La dissidenza religiosa in Russia, Claudiana- Torino 2000, p. 160. W łacińskiej wersji posłania Smery głoszona formula równego zejścia Świętego Ducha: «in nomine Patris Dei Omnipotentes et Filii eius Jesu Christi, et sancti Spiritus ex eadem Deo procedentis». 
narracji ruskiego latopisu „Powieści minionych lat”, ułożonego pod Kijowem na początku XII wieku. List Jołasza do księcia Włodzimierza, wyryty na dwunastu mosiężnych tablicach „starożytnymi ruskimi literami” (tu chodzi raczej o cyrylicki alfabet), został później rzekomo znaleziony w klasztorze św. Zbawiciela w Starym Samborze w ziemi przemyskiej przez skarbnika koronnego Stanisława Sobka i przekazany diakonowi Andrzejowi Kołodyńskiemu, który przetłumaczył go na język ruski, a następnie na polski. Podczas pobytu w Lublinie, Lubieniecki otrzymał jeden z licznych egzemplarzy listu od księdza Tylickiego, wówczas pisarza-ewangelika. ${ }^{10}$

Druga wersja historii wędrówki do Aleksandrii w poszukiwaniu prawdziwej wiary zawarta jest $\mathrm{w}$ łacińskim wydaniu Andrzeja Węgierskiego. W nim wędrówka ambasadora na skraj chrześcijańskiego Wschodu sięga 980 r.; kilka lat przed tym, jak książę Włodzimierz poślubił córkę (siostrę) cesarza bizantyjskiego Bazylego II Bułgarobójcy. Iwan Smera, uczony lekarz, udał się na Wschód, aby zaczerpnąć wiedzy o greckim chrześcijaństwie. Z Aleksandrii napisał list do Rusi, która następnie przyjęła chrześcijaństwo w obrządku bizantyjskim. Później ten list został przetłumaczony na język polski przez Andrzeja Kołodyńskiego w Witebsku ze starożytnych bułgarskich liter pisanych na złotych tablicach, które znaleziono w klasztorze Zbawiciela (Spasa) na ziemi przemyskiej w 1567 r. Relacja ta, podobnie jak u Lubienieckiego, wspomina o podróży przez Jerozolimę do Aleksandrii w Egipcie i opisuje dwie wersje chrześcijaństwa zaobserwowane przez Smerę. Świątynie jednej z nich nazywane przez autora synagogami, co odzwierciadla utrwaloną tradycję w Koronie Polskiej nieprzyjaznego określenia świątyń prawosławnych, a Grekom zarzucano bałwochwalstwo, przepowiadając ich „wieczną śmierć”: „aroganccy Grecy będą cierpieli w wiecznym ogniu”. Natomiast autor wyraża pozytywne nastawienie do innych Kościołów, w których, podobnie jak w protestanckich świątyniach, nie ma „bożków”, a jedynie ławy i stoły. W takich świątyniach przemawiają podobni do aniołów pobożni „czciciele” wybrani przez całą wspólnotę. Wierni,

10 A. Lubieniecki, Poloneutychia, Warszawa-Łódz 1982, s. 125. 
zwani „Nowym Izraelem”, zbierają się codziennie na polecenie Boga aby modlić się o świcie i po zachodzie słońca, to znaczy o godzinach trzeciej i dziewiątej. ${ }^{11} \mathrm{Tu}$ też zamieszczone zostało proroctwo, że Żydzi uznają Chrystusa za Zbawiciela. Elementy religijnego utopizmu i wizja idealnego ustroju są wpisane w narrację posłania Iwana Smery.

Opowieść o szczególnym miejscu Aleksandrii i straconych pismach można odnaleźć w innej legendzie, która została rozpowszechniona w czasach renesansu w Polsce. Skupiona jest ta opowieść na bardzo popularnym wtedy temacie genezy Słowian, która opowiadała o tak zwanym przywileju Aleksandra Macedońskiego. Uważa się, że Stanisław Orzechowski po raz pierwszy wspomina o przywileju Aleksandra w przedmowie do „Kroniki” (1544), w której opowiada legendę o pochodzeniu Polaków i innych Słowian. ${ }^{12}$ Orzechowski zauważa, że wzmianka o przywileju zapożyczona jest z „czeskich annałów”, które opisują nabywanie i zamieszkanie ziem Sarmacji Europejskiej przez Roksolana, Czecha i Lecha, wielkich dowódców wojskowych. Autor wielokrotnie podkreśla, że ojczyzną tych Słowian była Macedonia i Dalmacja. Taka narracja opiera się na renesansowej legendzie o praojczyźnie Polaków, Czechów i Rusów, która uzasadniona jednocześnie na średniowiecznej legendzie o pochodzeniu Słowian w kronice Wielkopolskiej o trzech braciach - Czechu, Lechu i Rusie (ostatni był dopisany później, po ułożeniu całości tekstu). Zmienioną wersję o przywódcach plemion przedstawił Jan Długosz, który pisał o tym, że Rus był synem Lecha, a Czech został wyznaczony na młodszego brata Lecha. ${ }^{13}$ Podobna legenda o trzech przywódcach, krytykowana przez Justa Scaligera, powstała we Fryzji i opowiadała, jak pisze Anthony Grafton, o trzech mężach-przywódcach - Fryzie, Sasie i Brunu - którzy przybyli z Indii czterysta lat przed Bożym Narodzeniem. Studiowali oni u Platona,

11 A. Wengerscii, Libri quattuor slavoniae Reformatae, Varsoviae 1973, p. 499-500.

12 F. Pfister, Die Entdeckung Alexanders des Großen durch die Humanisten [in:] Renaissance und Humanismus in Mittel-und-Osteuropa, Bd. 1, Berlin 1961, s. 73 .

13 J. Skomiał, Polscy kronikarze wieków śriednich o Rusi i Rusinach, „Annales Universitatis Mariae Curiae-Skłodowska”, vol. LIX (Sectio G), 2012, 1, s. 86. 
walczyli pod dowództwem Filipa II Macedońskiego i Aleksandra Macedońskiego, a następnie osiedlili się we Fryzji, skąd wypędzili gigantów, którzy zamieszkiwali Europę Północną. ${ }^{14} \mathrm{~W}$ kijowskiej „Powieści minionych lat” zawarte nawet dwie legendy o braciach-założycielach. Pierwsza opowiada o trzech braciach założycielach Kijowa i ich siostrze, druga o fundatorze dynastii kniaziów kijowskich: Ruryku i jego dwóch braciach Waregach, którzy przybyli razem na ruskie ziemie. ${ }^{15}$ Biskup Piotr z Biłhorodu pod Kijowem w swoim przemówieniu na Lyońskim soborze (1245 r.) opowiada o powstaniu dynastii tatarskich i mongolskich przewódców. Założyciel dynastii nomadów miał trzech synów: Tezir-chana, Churi-chan i Batatar-chana, którzy zdewastowali ruskie ziemie. ${ }^{16}$

Pseudoantyczna legenda o włoskich korzeniach Litwinów powstała na fali renesansowych poszukiwań początków etnicznych, według której Rzymski przywódca Palemon sprowadził plemiona litewskie na tereny bałtyckie. Ta legenda powstała na podstawie „Roczników” Jana Długosza, który kilka razy powraca w swoim arcydziele ku tematowi włosko-rzymskich korzeni Litwinów, przeprowadzonych na tereny nadbałtyckie przez legendarnego Wilię, który opuścił Rzym. Orzechowski odrzuca germańskie lub scytyjskie pochodzenie Polaków i potwierdza ich słowiańskie korzenie etniczne, przypominając o spokrewnieniu języka czeskiego, polskiego i ruskiego $\mathrm{Z}$ językiem macedońskim, dalmatyńskim i iliryjskim. ${ }^{17}$

Koncepcja przywileju Aleksandra Macedońskiego na ziemiach Polski, Ukrainy i Czech dla mieszkańców Dalmacji i Macedonii została rozwinięta w „Rocznikach polskich” Sarnickiego (Kraków, 1582), która niestety pozostaje poza uwagą współczesnej historiografii.

14 A. Grafton, Bring Out Your Dead: The Past as Revelation, Cambridge, Massachusetts, 2004, p. 136.

${ }^{15}$ Ipatiewskaia letopis (PSRL=2). t. 2, Moskva: Iazyki slavianskoi kul'tury 2001, kol. 7, 14.

16 MGH. Scriptores (in Folio). Hannoverae 1885, t. 27, p. 474-475; Annales monasterii de Burton, London 1864, vol. 1, p. 271-275; Matthaei Parisiensis, Chronicon majus. Ed. H.R. Luard, London 1877, t. IV, p. 386-389.

17 S. Orichovii, Annales, Posnaniae 1854, p. 7-9. 
W swoich poglądach wyznaniowych ewangelik Stanisław Sarnicki (1532-1597) opowiadał się za zbliżeniem z Braćmi Czeskimi, jak to miało miejsce w przypadku Kujaw. ${ }^{18} \mathrm{~W}$ wersji Sarnickiego "przywilej lub dyplom" Aleksandra zezwolił słowiańskim plemionom na osiedlenie się na ziemiach między Borystenem-Dnieprem i Dunajem $^{19}$. Wizja Dniepru jako granicy zamieszkiwania Słowian zdefiniowana rzekomo przez Aleksandra miała swoje ugruntowanie w dziełach geografa Ptolemeusza, jak wspomniał Sarnicki, określając terytorium „przestrzeni Aleksandra”. Sarnicki wspomina też na kartach swego dzieła o Sarmacji, podział której na Azyjską i Europejską wpływał na kształtowanie się tożsamości szlachty od czasów odrodzenia. Taki podział został wprowadzony przez starożytnego autora Pomponiusza Mele.

Odwołanie się do starożytnego źródła (przywilej Aleksandra) miało udowodnić historyczność dokumentu. Jak uważa Friedrich Pfister, Maciej Miechowita twierdził, że granica osadnictwa Słowian została określona przez ojca Aleksandra Macedońskiego Filipa II. Sarnicki stwierdza, że źródła o przywileju zostały odnalezione w archiwach Królestwa Czeskiego, a później były przekazane do krakowskiego klasztoru. Taka fabuła o podróży źródła odzwierciedla pewne wpływy „legendy o św. Hieronimie” poszerzonej w Koronie Polskiej pod wpływem zaistnienia ośrodka chorwacko-czeskiego, który wywierał wpływ na rozwój języków lokalnych na literaturę polską i ruską w XV wieku. Legenda o św. Hieronimie jako tłumaczu Pisma Świętego na język słowiański powstała we wczesnym średniowieczu. ${ }^{20}$ Zaś o św. Hieronimie jako tłumaczu Pisma Świętego z języka hebrajskiego wspominał już późnoantyczny autor Kasjodor. ${ }^{21}$ Klasztor benedyktynów-Chorwatów powstał najpierw w Pradze, a później na

18 J. Bidlo, Jednota bratska v prvním vyhnanství, č. II (1561-1572), Praha 1903, s. 145.

${ }^{19}$ F. Pfister, Die Entdeckung Alexanders des Großen durch die Humanisten, s. 74;

S. Sarnicii, Annalium Polonicorum, Kraków 1587, p. 44.

${ }^{20}$ J. Verkholantsev, The Slavonic Letters of St. Jerome: The History of Legend and Its Legacy, DeKalb, 2014, p. 60-61.

${ }^{21}$ Cassiodorus M.A. Cassiodori, Opera omnia, Lutetia 1865, t. II (Patrologia Latina, t. 70), col. 1123-1124. 
krakowskim Kleparzu. Działalność klasztorów jest znana dzięki tłumaczeniu tekstów tradycji katolicko-łacińskiej na języki słowiańskie.

Według Sarnickiego, Lech poprowadził osadników z Ilirii do zdewastowanej Sarmacji. Autor aktywnie przywołuje korzenia antyczne i wyjaśnia współczesną etymologię przez pryzmat historii starożytnej. Na przykład stwierdza, że nazwa miejscowości Dziwczy Grad na Śląsku wskazuje, że Amazonki poślubiły Sarmatów i tu właśnie zamieszkały. ${ }^{22}$ Przypomina, że brzegi Borystenu były zamieszkane przez ludność „,dolnych Kozaków”, pochodzenie których kojarzy się z czasami Kimeryjczyków. Stanisław Sarnicki wspomina o udziale tego ludu w wojnie między Troją i Cimborami, ludu, który poszukiwal doli w falach Borystenu. Opisuje Roksolanów jako wojowniczy lud, a Kozacy, zgodnie z jego wersją, musieli walczyć z Mitrydatesem królem pontyjskim, który toczył boje ze Scytami. ${ }^{23}$ Poszukiwania etniczne Sarnicki ugruntował na pracach wspomnianego wyżej Tritemiusza. Sarnicki znajduje Gotów („getta”) na przestrzeniach Sarmacji: na przykład uważa, że imię Markomir - w rzeczywistości, według Grzegorza z Tours, nie jest Gotem ani Gettem, ale Frankiem, przodkiem Merowingów i „synem” Priama z Troi - znajdowało odzwierciedlenie w imionach Kazimir, Włodimir, Ludomir, bo język Gotów jest spokrewniony $z$ polskim i sarmackim. ${ }^{24}$ Fakt, że autor zwraca szczególną uwagę na Kozaków, odzwierciedla stworzenie ich pierwszego rejestru w 1578 r., niebawem odbyła się wyprawa przeciwko Moskwie pod dowództwem króla Stefana Batorego i wojewody kijowskiego Wasyla Ostrogskiego (1581). ${ }^{25} \mathrm{O}$ obyczajach Kozaków opowiadał też Jan Orzelski, który był uczestnikiem wyprawy i prowadził pertraktacje z nimi. ${ }^{26}$ Maciej Stryjkowski (1582 r.) traktuję Kozaków jako lud wojowniczy i pograniczny. Wspomina,

\footnotetext{
22 S. Sarnicii, Annales Polonorum, p. 23.

${ }^{23}$ Ibidem, p. 29.

${ }^{24}$ Ibidem, p. 39.

${ }^{25}$ P. Kułakows'kyj, Do istorii stsunkiw rejestrowych kozakiw i prykordonnych starost u 1578-1583 rokach, „Visnyk L'vivs'kogo uniwersytetu: Serija istoryczna”, vyp. 34, 1999, s. 407-423.

${ }^{26}$ Annales Domus Orzelsciae per Joannem Orzelski, Posnanie 1854, p. 26-27.
} 
że „Jatwieziów też do Mazowsza i Lubelskiej ziemię kozactw drapieżnymi ustawicznie nasyłali, których tegoż Bolesław Wstydliwy poraził i wykorzenił z Podlasza"27. To, że polski król jest wspominany w kontekście „Kozaków” i wyprawy przeciw Jaćwieży, nie jest przypadkowym. Na czas panowania Bolesława przypadają wojny toczone przeciwko Jaćwieży po przywództwem ruskiego księcia Daniela Romanowicza.

Oczywiście, oprócz takiego "hiperantycznego" poglądu, w okresie renesansu zaistniało również krytyczne podejście ku głoszonym opowieściom o starożytności Polaków, które wyszło spod pióra przybysza z ziemi włoskiej Filipa Kallimacha. W swoim dziele z 1476 r., ponad sto lat przed ukazaniem się kroniki Sarnickiego, Kallimach odrzucił stwierdzenie średniowiecznego dziejopisarza Wincentego Kadłubka, który prześledził pochodzenie Polaków niemal od czasów biblijnego Potopu, twierdząc, że byli tymi samymi Scytami, z którymi walczył Aleksander Macedoński, a rzymianin Grak (Krak) wtedy założył Kraków. Zdaniem Kallimacha warto odrzucić te „babskie kłamstwa”. Przypuszczalnie pod wpływem Jordanowego "Gotyku” przypomina, że Polacy byli w zwyczajach zbliżeni do wenedów-pomorzan i sarmatów: łączyło ich ograniczenie praw władcy, którego potęga nie była ani najwyższa, ani nieograniczona. ${ }^{28}$ Odrzucenie legendy o grecko-rzymskim pochodzeniu Polaków służy Kallimachowi dla wprowadzenia nowej teorii politycznej, która ogranicza absolutyzm monarchy. W Kallimachowej konstrukcji starożytnego społeczeństwa istotnymi są wpływy koncyliaryzmu, który doprowadził do zmian politycznej teorii doby odrodzenia. Według teorii koncyliarystów, rozwijanej paryskimi uczonymi od początku XV wieku, sobór całego Kościoła stawał wyższym nad papieży, a absolutyzm ich władzy jest

${ }^{27}$ M. Stryjkowski, Kronika Polska, Litweska, Żmudzka i wszystkiej Rusi, t. 1, Warszawa 1980, s. 9.

${ }^{28}$ P. Callimachi, Vita et mores Gregorii Sanocei, Varsoviae 1958, p. 36-37. Jordanowa "Getyka” jest późnoantyczną kosmografią, która opowiada o Wielkiej wędrówce luduów, czasem przypisywana autorstwu Kasjodora. Nanowo została otwarta w 1442 r. przez wybitnego działacza włoskiego renesansu Eneusza Piccolominiego, a pózniejszego papieża Pijusza II. 
ograniczony. Później ta teoria została przełożona na życie polityczne i miała wpływ na rozwój zasad wyborności władcy. ${ }^{29}$

W swojej opowieści o przywileju Słowianom, Stanisław Sarnicki pragnął tworzyć wizję dokumentu historycznego, rzeczywistego, zachowanego w kilku odmianach językowych: bułgarskiej, chorwackiej, greckiej. Jedna $z$ dawnych wersji przywileju została napisana po grecku, złotymi literami na pergaminie, w egipskiej Aleksandrii. Ale wraz z podbiciem Konstantynopola przez Mahometów, dokument trafił do tureckiego skarbca, w końcu w Czechach zostało odnalezione słowiańskie tłumaczenie przywileju. Legenda o dyplomie Aleksandra Macedońskiego była również znana w Wenecji w 1550 r. ${ }^{30}$ Historia legendy o przywileju Słowian została zbadana przez Friedricha Pfistera: powstała ona na początku XVI wieku, a niektóre z jej fragmentów można zobaczyć w pismach Siegmunda von Herbersteina. Kolejny zabytek, który przyczynił się do powstania legendy o przywileju, jest wymieniona przez badacza - czeska kronika Hajeka (1541), która przedstawia przesiedlenie władców Chorwacji i Ilirii, Czecha i Lecha, na tereny Czech i Polski w 644 r., chociaż przywilej Aleksandra nie został tutaj wymieniony. ${ }^{31}$ Pfister zauważa, że przy okazji założenia klasztoru benedyktynów św. Kosmy i Damiana w Pradze (1348), gdzie mieli prowadzić liturgię w języku słowiańskim w imieniu św. Hieronima, wymienione są tylko pozdrowienia dla Słowian od Aleksandra. Dopiero u Orzechowskiego legenda o przywileju nabiera ostatecznej formy, o czym pisze Bartosz Paprocki. ${ }^{32} \mathrm{~W}$ związku z tym można wysnuć wniosek, że historia ukrytych i odnalezionych pism w Aleksandrii opisana przez Sarnickiego mogła mieć wpływ na historię o Iwanie Smerze, który odwiedził Aleksandrię, gdzie napisał tekst opisujący lokalną społeczność chrześcijańską, zwyczaje której są bliskie przykazaniom kalwinizmu.

${ }^{29}$ F. Oakley, Politics and Eternity: Studies in the History of Medieval and Early Modern Political Thought, Leiden, Boston, Köln 1999, p. 149-185.

${ }^{30}$ S. Sarnicii, Annales Polonorum, Kraków, 1587, p. 46.

${ }^{31}$ F. Pfister, Das Privilegium Slavicum Alexanders des Großen, „Zeitschrift für Slawistik", Bd. V, 1961, H. 3, s. 325.

32 Ibidem, s. 333-335. 
Przekonanie, że Aleksandria jest wymarzonym miejscem dla ewangelików, wynika $z$ prób nawiązania kontaktów przez przywódców tego Kościoła $\mathrm{z}$ lokalnym patriarchą w drugiej połowie XVI wieku, a jednocześnie przyciągano uwagę ku tej miejscowości $\mathrm{z}$ tego powodu, że był to kiedyś centrum dysydenctwa religijnego. Te dwa przykłady (List Smery i przywilej Aleksandra Macedońskiego) dobrze pokazują, jak powstała „nowa przeszłość”, w jakiej elementy narracji historycznej były połączone $\mathrm{z}$ fikcyjnymi fabułami w celu potwierdzenia starożytności etnosu lub wyznania.

\section{References}

Annales Domus Orzelsciae per Joannem Orzelski, Posnanie 1854.

Annales monasterii de Burton, vol. 1, London 1864.

Bidlo J., Jednota bratska v prvním vyhnanství, č. II (1561-1572), Praha 1903.

Callimachi P., Vita et mores Gregorii Sanocei, Varsoviae 1958.

Cassiodorus M. A. Cassiodori, Opera omnia, Lutetia 1865, t. II (Patrologia Latina, t. 70), col. 1123-1124.

Gordon B., The Changing Face of Protestant History and Identity in the Sixteenth Century [in:] Protestant History and Identity in Sixteenth-Century Europe, Vol. 2: The Later Reformation, Aldershot 1996.

Grafton A., Bring Out Your Dead: The Past as Revelation, Cambridge, Massachusetts 2004.

Grafton A., Worlds Made By Words: Scholarship and Community in the Modern West, Cambridge 2011.

Golenchenko H. Ideinyie i kulturnyie sviazi vostochnoslavianskikh narodov v XVIseredinie XVII v. Minsk 1989.

Ipatiewskaia letopis (PSRL=2). t. 2, Moskva: Iazyki slavianskoi kul'tury 2001.

Kułakows'kyj P., Do istorii stsunkiw rejestrowych kozakiw i prykordonnych starost u 1578-1583 rokach, „Visnyk L'vivs'kogo uniwersytetu: Serija istoryczna”, vyp. 34, 1999.

Lubieniecki A., Poloneutychia, Warszawa-Łódz 1982.

Malishevskii I. Podlozhnoie pis'mo polovtsa Ivana Smery k velikomu kniaziu Vladimiru Sviatomu, Kyiv 1876.

Luard H. R., ed, Matthaei Parisiensis Chronicon Majus, vol. IV, London 1877.

Monumenta Germaniae Historica. Scriptores (in Folio). Ex rerum Anglicarum scriptorebus saec. XII et XIII, T. 27, ed. Lieberman F. \& Pauli E. Hannoverae: Typis Culemmanorum, 1885. 
Oakley F., Politics and Eternity: Studies in the History of Medieval and Early Modern Political Thought, Leiden, Boston, Köln 1999.

Orichovii S., Annales, Posnaniae 1854.

Pfister F., Das Privilegium Slavicum Alexanders des Großen, „Zeitschrift für Slawistik", Bd. V, 1961, H. 3.

Pfister F., Die Entdeckung Alexanders des Großen durch die Humanisten [in:] Renaissance und Humanismus in Mittel-und-Osteuropa, Bd. 1, Berlin 1961.

Ronchi de Michelis L., Eresia e riforma nel cinquecento: La dissidenza religiosa in Russia, Claudiana-Torino 2000.

Ronchi L., Predicazione riformata e ortodossia in Lituania nel 16 sec.: La Epistola di Ivan Smera sulla conversion della Russia, „Protestantismo”, An. 50, fasc. 3, 1995.

Sarnicii S., Annales Polonorum, Cracoviae 1587.

Skomiał J., Polscy kronikarze wieków śriednich o Rusi i Rusinach, „Annales Universitatis Mariae Curiae-Skłodowska", vol. LIX (Sectio G), 2012, 1.

Tazbir J., Falsyfikat w stużbie propagandy różnowierczej [w:] Kościót, społeczeństwo, kultura: Prace ofiarowane profesorowi Wiesławowi Müllerowi z okazji pięćdziesięciolecia pracy naukowej i dydaktycznej, Lublin 2004.

Verkholantsev J., The Slavonic Letters of St. Jerome: The History of Legend and Its Legacy, Cornell University Press, 2014.

Wengerscii A., Libri quattuor slavoniae Reformatae, Varsoviae 1973. 


\title{
Mykola Krupach
}

Lviv Ivan Franko National University (Ukraine)

ORCID: 0000-0002-0911-1693

\section{«3 лупою літературного детектива» (До проблеми ідентифікації утаємничених текстів)}

\section{"With a Magnifying Glass of a Literary Detective" (The problem of identifying clandestine texts)}

\begin{abstract}
:
The article "Contemporary Ukrainian Poetry" by Oleh Olzhych has been given the status of an authoritative source in domestic literary criticism in recent decades, in particular, in the study of the genesis of emigrant poetry of 1920-1930 and in general on the interpretation of the state of national literature in eastern and western countries, which in the interwar period were respectively under the rule of Russia and Poland. Only the "textual coincidences, general concept and intonation" of the article and Olzhych's related texts were taken as the basis of identification. Such a technique contains elements of pre-programming of the final result and can lead to erroneous conclusions in identifying the author of the publication. It draws attention to the analogies of text construction, subject matter, lexical and stylistic coincidences, etc., but distracts from what is the main in the objective establishment of the publication of a particular person - the (internal) content of the text. The example of Olzhych's attitude to the process of development of national literature in the interwar period and especially to the work of his father (Oleksandr Oles) shows that he can't be the author of a politically quite controversial article "Contemporary Ukrainian Poetry".
\end{abstract}

Keywords: article Contemporary Ukrainian Poetry, identification of authorship, ideological bias, O. Olzhych, O. Oles. 
Як уже доводилося зазначати믈 статті Б.-I. Антонича Роеzја ро tej stronie barykady, вперше опублікованій 1934 року в польському журналі «Sygnały»², та оглядові Сучасна українська поезія у вітчизняному літературознавстві останніх десятиліть деякими дослідниками надано статус авторитетних джерел, зокрема, при дослідженні генези еміграційної поезії 1920-1930 рр. та загалом щодо інтерпретації стану розвитку національної літератури на східно- та західноукраїнських землях, які в міжвоєнний період перебували під владою відповідно Росії та Польщі. Авторство огляду Сучасна українська поезія приписують О. Ольжичу, котрий був не тільки фаховим істориком, письменником, але й одним із лідерів ОУН, що після розколу організації залишився у її т. зв. «мельниківському» Проводі й у червні 1944 р. був закатований у німецькому концтаборі Заксенгаузен. Зосібна цей огляд увійшов до таких вагомих видань творів письменника, як книги Незнаному Воякові ${ }^{3}$ та Поезія. Проза ${ }^{4}$. Однак упорядники цих збірників не назвали жодних серйозних аргументів, які підтверджують ідентифікацію авторства огляду. Більш того, у книгах уміщені дещо відмінні варіанти цієї оглядової статті. Так, в одному із них вказано, що огляд Сучасна українська поезія повністю або частково був написаний орієнтовно 1938 р., а опублікований за підписом «А. Б.» аж у середині 1942 р. в «Українському віснику» ${ }^{5}$, що виходив у Берліні.

Дійсно, в огляді $є$ певні текстуальні подібності, що вказують на його ймовірний зв'язок із деякими статтями О. Ольжича, зосібна із статтею Українська культура, яка також 1942 р. (зразу ж після публікації огляду Сучасна українська поезія) була надрукована в тому самому періодичному виданні та підписана вже звичним для письменника псевдонімом - Д. Кардаш.

${ }^{1}$ M. Krupach, Geneza tematyky ukrainskoi emihratsiinoi poezii 1920-1930-kh rokiv u interpretatsii B.I. Antonycha, "Spheres of culture", Volume V, Lublin 2013, s. 133-141.

2 B. I. Antonycz, Poezja po tej stronie barykady, „Sygnały”, 1934, nr 4-5, s. 3-4.

3 O. Olzhych, Neznanomu Voiakovi, Kyiv 1994, s. 173-185.

${ }^{4}$ O. Olzhych, Poeziia. Proza, Kyiv 2007, s. 191-201.

${ }^{5}$ Ibidem, s. 200, 509, 511. 
Загалом доведення авторства публікації надзвичайно складна, довготривала та скрупульозна робота над текстом, котру потрібно, як із дещо іншого приводу висловився С. Гординський, здійснювати «з лупою літературного детектива»6. Однак завданням цієї публікації не є спроба визначити дійсного автора статті Сучасна украӥнська поезія, котрого з-поміж іншого можна запідозрити навіть в упередженій презентації процесу розвитку української літератури в міжвоєнний період на територіях, що перебували під владою, зокрема, Росії та Польщі. Наприклад, аналізуючи «поезію Західної України», автор огляду твердив про «часи польської окупації», що начебто витворили на цих землях «окремий тип поетів», котрі «пишуть тільки періодично,

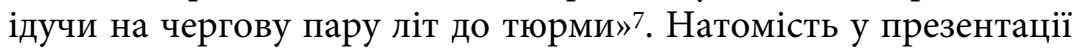
східноукраїнської літератури автор огляду твердив про панування на цих землях «большевицької влади» та лише поступове «посилення московського наступу». А про масові репресії та політичні переслідування на цих теренах якщо і згадував, то часом у якомусь аж надто хаотично-грайливому стилі (як от: «3 Рильським та іншими величинами відбув „балачку” сам Постишев» тощо) $)^{8}$, не характерному для аналітично виважених публікацій О. Ольжича.

Так, у дослідженні Українська культура, пишучи про «большевицьку окупацію», О. Ольжич виділяв у ній «добу сталінізму», яку ще називав «добою репресій», коли була остаточно знищена національна література на східноукраїнських землях. Щодо західноукраїнських земель, то О. Ольжич якраз підкреслював, що у 1920-1930 рр. там були «деякі можливості» для культурної діяльності українців навіть попри «брак постійної лінії поступування зі сторони поляків»9. Також автори обох оглядів вважали, що

${ }^{6}$ S. Hordynskyi, Na perelomi epokh. Literaturoznavchi statti, ohliady, esei, retsenzii, spohady, Lviv 2004, s. 103.

7 O. Olzhych, Neznanomu Voiakovi..., s. 183.

8 Ibidem, s. 175, 179.

9 Ibidem, s. 223-224. 
започаткування української еміграційної літератури відбулося 1922 р. на території Польщі. Зосібна, за О. Ольжичем, у «таборі інтернованих в Каліші». А у статті Сучасна украӥнська поезія чита$€$ єо, що в «концентраційних польських таборах, де було інтерноване українське військо» ${ }^{10}$. Якщо взяти до уваги, що обидві публікації побачили світ у націоналістичному виданні 1942 р., тобто напередодні загострення українсько-польських протистоянь (коли і Україна, і Польща вже були окуповані німцями та їхніми союзниками), то ці та інші політичні аспекти оглядів потребують окремих розлогих коментарів дискусійного характеру.

Отож мета запропонованої статті - зосередити увагу дослідників на проблемах більш скрупульозної ідентифікації авторства низки утаємничених публікацій, зосібна тих, що містять оціночні судження політичного характеру. Адже насправді вони можуть виявитися маніпулятивними вкиданнями в інформаційний простір, зокрема, з метою загострення як внутрішніх, так і міжнаціональних протистоянь. Відповідно основним завданням цієї публікації $є$ виклад окремих аналітичних спостережень саме аполітичного (зокрема формального та біографічного) характеру, що заперечують приналежність огляду Сучасна украӥнська поезія перу О. Ольжича.

У науковій літературі знаходимо чимало прикладів обгрунтування приналежності тексту конкретному авторові. Однак кожна ідентифікація, зокрема, анонімної чи втаємниченої публікації вимагає розроблення індивідуальної методики, що обумовлена ступенем складності поставлених перед дослідниками проблем. Загалом ідентифікація тексту передбачає передусім збір формальної інформації, яка випливає з його різнобічного аналізу та вибудовує індивідуально-комплексний абрис ймовірного автора, але не як конкретної особи, твори котрої прагнуть віднайти, а цілком автономної.

Із примітки упорядника книги Незнаному Воякові можна прийти до висновку, що при визначенні авторства статті Сучасна

${ }^{10}$ Ibidem, s. 180, 220. 
украӥнська поезія ця фаза дослідження була дещо проігнорована, про що вже доводилося писати ${ }^{11}$. За основу ідентифікації начебто були взяті лише «текстуальні збіги, загальна концепція й інтонація [тут і далі всі виокремлення в цитатах мої - M. К.]» ${ }^{12}$ цього огляду та, очевидно, деяких інших текстів О. Ольжича, передусім споріднених за жанром. Подібна методика містить у собі елементи попередньої запрограмованості кінцевого результату і може призвести до хибних висновків щодо ідентифікації автора публікаціі. Вона привертає увагу до поверхневих аналогій (побудови тексту, тематики, лексичних та стилістичних збігів тощо), але відволікає від основного в об’єктивному встановленні приналежності публікації конкретній особі - змістового (внутрішнього) наповнення тексту. Зосібна перешкоджає визначити основні параметри ідейних напрямів (векторів) світогляду автора, що (попри можливі уніфікації, характерні для політично-культурного оточення) обов'язково містить елементи індивідуальності, які виражаються в певних суб'єктивних оцінках окремих явищ чи персоналій та які в певний період історичного часу проявляються в конкретних твердженнях.

Так, поняття «загальна концепція» публікації може мати двояке трактування. Коли мова йде про загальну концепцію тексту, як про його ідейний задум, то потрібно зазначити, що вона для будь-кого літературного огляду є досить трафаретною, тому подібність статті Сучасна украӥнська поезія до, наприклад, відповідного фрагменту Ольжичевого дослідження Украӥнська культура обумовлена уніфікованими критеріями. Проте коли розглядати концепцію як систему доказів окремих положень, поглядів на те чи інше явище або спосіб розуміння та тлумачення ïx, то в обох текстах вони явно різняться.

11 M. Krupach, "Pershyi” ta "druhyi" poety "Prazkoi shkoly”: problema avtentychnosti „svidchen avtorytetnykh myttsiv", "Pomiędzy. Між. Между. Between. Zwischen. Entre: Polonistyczno-Ukrainoznawcze Studia Naukowe, Wrocław 2015, №. 1, s. 219-232.

12 O. Olzhych, Neznanomu Voiakovi..., s. 426. 
Передусім кожен літературний огляд має мати чітко визначену хронотопну структуру, об'єкт, предмет, мету й завдання дослідження. Зокрема, у статтях Сучасна українська поезія та Українська культура наявні часово-просторові координати дослідження, які збігаються. Для порівняльної зручності часові обмежимо 1920-1930 рр. Відповідно в той період просторові координати в обох публікаціях сумарно представлені так: «Східні Українські Землі» (далі - «СУЗ»), «Західні Українські Землі» (далі - «ЗУЗ»), Західна Волинь, Закарпаття, Буковина, еміграція. Оскільки територіальний поділ розселення українців у 1920-1930 рр. є константним, то він має бути відображений у будь-якому літературному огляді того часу. Звідси випливає іх перша жанрово-структурна уніфікація. Однак, приступаючи до написання конкретного огляду, автор повинен вирішити, у якій географічній послідовності він розглядатиме літературу окремого регіону, а також переконатися, чи $€$ в нього на той час фактологічний матеріал, аби охопити кожен із них. Таким чином, вибудовується вже певна індивідуально-авторська концепція структури («композиції) дослідження.

Автор статті Сучасна українська поезія говорить про розвиток поетичної творчості на окремих теренах у такій послідовності: СУЗ - еміграція - Західна Волинь - ЗУЗ - Закарпаття Буковина. В огляді Українська культура географічна складова структури презентації національної літератури явно різниться: еміграція - Закарпаття - Буковина - $3 У 3$ - СУЗ. Отже, виникає запитання, для чого О. Ольжичеві, якщо він дійсно автор цих двох оглядів, один за одним надрукованих у тому самому періодичному виданні, потрібно було терміново змінювати географічну складову структури публікацій? Таке перетасовування фрагментів тексту мимоволі спонукає уважного читача побачити в спільному авторстві цих двох оглядів сумарний абрис якогось маніпулятивного презентанта, який, наприклад, зацікавлений у якомога більшій кількості публікацій, але аж ніяк не О. Ольжича - скрупульозного ученого, політичного діяча, філігранного поета. 
Наведений приклад уже доволі рельєфно ілюструє, що концептуальні засади обох оглядів доволі відмінні. Більш того, якщо їх і далі уважно аналізувати, то в них знайдемо й чимало інших розбіжностей. Однак це вже теми окремих студій, які потребують скрупульозного вивчення політичних векторів презентованих у текстах ідей. Наприклад, автор огляду Сучасна украйнська поезія нав'язує читачеві політичну установку, буцімто в 1920-1930 pр. національна (а то й націоналістична) література найбільшого розвитку зазнала саме на східноукраїнських землях, що перебували під протекторатом «большевицької влади». Він навіть оголосив «націоналістом» М. Хвильового ${ }^{13}$, котрий (як проросійський червоноармієць-чекіст) був причетний до збройного повалення влади УНР та до кінця життя залишався ідейним комуністом. Така позиція автора огляду навіть апріорі мала викликати щонайменше дискусію в націоналістичному таборі. І якраз стаття Украӥнська культура засвідчує, що саме О. Ольжич вступив у приховане протистояння з втаємниченим автором огляду. Неспроста О. Ольжич літературу «СУЗ», розуміючи ступінь просякнення іiі комуністичними ідеями, у процесі осмислення здобутків національної культури поставив на останнє місце. Натомість правофланговою в міжвоєнний період він оголосив саме літературу української еміграції, започатковану на території Польщі.

Аби ще раз серйозно засумніватися в непричетності О. Ольжича до написання статті Сучасна українська поезія, достатньо різнобічно проаналізувати хоч би один із їі початкових фрагментів, де, зокрема, наявне таке концепційне твердження про розвиток української поезії перших десятиліть ХХ століття:

Чупринка бере до рук рушницю повстанця і падає під кулями ЧеКа. Олесь, Вороний, В. Самійленко, С. Черкасенко, Пачовський ідуть на еміграцію виспівувати свій біль і незломну віру на холодному камінні чужих столиць. Інші замовкають назавжди. I коли чуємо ще тепер голоси поетів цієї генерації, поетів, що з них мало хто зломився, то все

${ }^{13}$ Ibidem, s. 176. 
це $є$ голоси з минулого, чужі новій суворій добі. Сучасна українська поезія - це нові люди і нові слова ${ }^{14}$.

Звичайно, у процитованому фрагменті навіть без особливих зусиль можна відшукати «текстуальні збіги, загальну концепцію й інтонацію», характерні для творчості О. Ольжича. Так, наприклад, у вірші «Двадиять літ кривавиться земля...» згадана «доба жорстока», в якій «ростуть» на зміну загиблому, але «непокоримому поколінню» саме «брати, суворі і великі» 15 , тобто також виростають «нові люди». Коли врахувати, що в обох фрагментах наявні такі синонімічні пари, як «суворий та жорстокий», «незламний та непокоримий», «генерація та покоління», а також є спільна лексема «доба», то вже начебто бачимо в них явні «текстуальні збіги». Також в обох текстах начебто є і спільна ідеологічна «концепція», а саме - «жорстокої», «суворої доби» та зміни «поколінь» у боротьбі за власну землю, що обумовлює багато в чому і споріднену в них «інтонацію», яку можна окреслити як «незламну». Варто також звернути увагу, що для порівняння взяті ще й кардинально різні за жанром тексти. Тож уже начебто достатньо підстав, аби запевняти, що вони обидва можуть належати одному авторові.

Та для ідентифікації авторства більш важливою є наступна стадія порівняльного аналізу, в результаті якого дослідник уже повинен абстрагуватися від будь-яких текстуальних аналогій, а якраз зосередитися на виявленні відмінностей - передусім ідейного та смислового характеру. Для цього, зокрема, необхідно перечитати цитований фрагмент статті Сучасна украӥнська поезія, гіпотетично допустивши, що його автором є саме О. Ольжич. У такому разі зразу ж впадає у вічі, що в уривку згаданий О. Олесь - батько письменника. Тож цілком логічно провести маркірування синової рецепції творчого здобутку батька, яка начебто випливає з фактологічної інформації, наявної в цьому

\footnotetext{
14 O. Olzhych, Poeziia. Proza..., s. 192.

15 Ibidem, s. 31.
} 
фрагменті, та для порівняння спробувати віднайти ії в інших текстах О. Ольжича, зокрема написаних орієнтовно в той же період, але авторство котрих не викликає сумнівів.

Зосібна публічна рецепція висловлювань, наявних у статті Сучасна українька поезія, набрала чинності з моменту виходу статті, тобто 331 травня 1942 p. ${ }^{16}$ На той час із перелічених у цитованому фрагменті поетів попередньої «генерації» живим залишився тільки О. Олесь. Тож автор статті «чути ще тепер голос» міг тільки його. Та в будь-якому випадку, що ж почув батько в публічному монолозі сина, якщо той дійсно був автором огляду?

Результати такого ймовірного звернення щонайменше спантеличують: син, хоч і дещо похвалив батькову творчість, та все ж перекреслив іiі, назвавши «чужою» йому, та відправив у «минуле», тобто фактично - похоронив, як ідейно погріб доробок й інших поетів попередньої генерації, котрі, згідно 3 авторським переліком, вже дійсно відійшли з життя. Себе ж, як випливає із загального контексту статті, відніс до «нових людей» із «новими словами». Тож начебто О. Ольжич проголосив себе поетом майбутнього, котрому, на відміну від батька, таки вдасться перемінити світ у вже «новій суворій добі». У такому разі цинізм та чванство О. Ольжича, не кажучи вже про такі аморальні категорії, як синівська бездушність, черствість, невдячність, егоїстичність тощо, буквально вражають.

О. Олесь набагато раніше за свого сина став одним із найпотужніших співців пробудження національно-державної свідомості українського народу. У значній мірі й завдяки його творчості виросло нове покоління борців за незалежність України, котре вже проявило себе в національно-визвольній боротьбі 1917-1921 років. Ще більш цинічним та пихатим виглядало 6 таке синівське зречення творчості батька, коли читати варіант статті Сучасна украӥнська поезія, уміщений у книзі Незнаному Воякові, де невідомо хто приписав О. Ольжичеві начебто

16 O. Olzhych, Neznanomu Voiakovi..., s. 426. 
адораційну самохарактеристику власної творчості, яка до того ще й фактологічно недостовірна ${ }^{17}$.

Водночас виникає запитання: чи дійсно О. Ольжич міг так категорично відгороджувати власну творчість від батькової? Якщо звернутися до автентичних текстів О. Ольжича, то там якраз не знаходимо жодних протистоянь не тільки між його та батьковою творчістю, але й між їх ідейно-життєвою позицією. Більш того, син вважав, що разом зі спільниками (представниками молодшого покоління) він іде тим же «українським шляхом», на який ще 1903 року вступив його батько. Так, у листі до О. Олеся, написаному орієнтовно 1943 р., тобто невдовзі після публікації статті Сучасна украӥнська поезія, О. Ольжич писав:

Десь далеко той [1]903 рік, коли Ти, молодий і дужий, ставив свої перші кроки на тому українському шляху, що ним так без ліку іде нас тепер, бадьорих і знесилених, але однаково зв'язаних з ним до останнього подиху. Я бачу яскравіше в уяві 1907 рік і 1912, коли ти писав «По дорозі в казку» і їздив до Криворівні, бачу Пущу, хвилююся, згадуючи зими [19]18 і [19]19 років... ${ }^{18}$.

Звичайно, гіпотетично можна припускати, що О. Ольжич лише публічно оголошував чужою йому творчість батька, а в приватному листі вводив його в оману, твердячи, буцімто вони все ж ідуть спільним «українським шляхом». Але й таке припущення заперечують окремі твердження О. Ольжича, зосібна публічно висловлені саме в дослідженні Украйнська культура.

Так, автор огляду Сучасна українська поезія твердив, що «під прапорами естетики й символізму» О. Олесь увійшов у літературу разом із М. Вороним, Г. Чупринкою та галицькою «Молодою Музою» ${ }^{19}$. На відміну від нього, у статті Украйнська культура із перелічених попередником поетів лише М. Вороний зарахований О. Ольжичем до символістів, які, на його думку,

17 Ibidem, s. 182-183.

18 O. Olzhych, Vybrani tvory, Kyiv 2009, s. 363.

19 O. Olzhych, Poeziia. Proza..., s. 191. 
загалом хоч «і прийшли як реакція по невдачах революції 1905 р.», але у «творчості своїй $€$ „світові”, а цим і мало національні». Далі О. Ольжич якраз наголошував, що саме

поети Олесь і Чупринка утримують тісний зв'язок з українською національною дійсністю, що виявляється у першого сильним реагуванням на життя в Україні та передчуттям великих подій недалекого будучого та через впливи народної творчості мова й світовідчуття його $€$ виразно національні, тоді як у Чупринки помітний неспокій, вичуття свого трагічного майбутнього й героїчний порив. Обидва, хоч були близькі до символістів, мають сильний контакт із життям, й суспільна та національна ідея у них $є$ рушійною силою ${ }^{20}$.

Також, на думку О. Ольжича, й у часи національно-визвольних змагань 1917-1921 рр. далі «співи боротьби і перемоги дзвенять у творчості Олеся» ${ }^{21}$.

Як бачимо, й у публічній візії О. Ольжича, що змальована у статті Українська культура, він іде з батьком так само спільним «українським шляхом», початок якого проглядає ще в глибині тисячоліть. I між ними немає ніяких ідейно-творчих протистоянь, що їх намагався нав'язати автор огляду Сучасна украӥнська поезія, зокрема, як між представниками різними поколінь національних поетів. Тож О. Ольжичеві загалом явно чужа концепція попередника про виникнення після поразки національно-визвольної боротьби 1917-1921 рр. «новітньої націоналістичної духовності героїчного типу» 22 без органічного зв’язку поколінь. Її предтечу в літературі він вбачає не тільки у творчості Т. Шевченка, I. Франка, Лесі Українки, але, зокрема, і свого батька (О. Олеся) та Г. Чупринки. Цікаво, що й у цитованому вірші «Двадиять літ кривавиться земля...» О. Ольжича так само немає жодних протистоянь між поколіннями борців за власну землю.

У статті Украӥнська культура навіть відчутно, що зневажливо-відчужене ставлення автора огляду Сучасна украӥнська

\footnotetext{
20 Ibidem, s. 239-240.

21 Ibidem, s. 242.

22 Ibidem, s. 201.
} 
поезія (котрий начебто належить до соратників сина - теж «націоналістів»), зокрема, до творчості О. Олеся глибоко ранило О. Ольжича, тому в дуже скупих характеристиках доробку інших письменників, що обумовлені жанром публікації, він дещо ширше зупинився саме на дореволюційній творчості свого батька, аби фактологічно заперечити несправедливі оцінки попередника. Не виключено також, що під впливом ідеї відчуження, зокрема Олесевої поезії від творчості нового покоління поетів, висловленої автором у статті Сучасна украйнська поезія, О. Ольжич і заговорив у листі про спільний з батьком «український шлях», обрамлюючи цитований фрагмент словами надзвичайно ніжної синівської любові:

Мій дорогий батьку! [...] Мені хотілося 6 схилитися коло Твого ліжка і притиснути Твою руку до моєї щоки [...] Боляче мені, мій дорогий, за Тебе і за себе, що не приніс я Тобі стільки підпори і потіхи, скільки мав би і скільки Ти потрібував [...] А тепер мені тільки смутно і хочеться поцілувати Твої руки і дороге, схудле обличчя ${ }^{23}$.

За якийсь час після написання цього листа О. Ольжича не стало. Дізнавшись про мученицьку смерть сина, слідом за ним помер й О. Олесь. Однак і досі в низці публікацій пропагується міф про їх начебто ідейно-творчі протистояння, інспірований, зокрема, не тільки втаємниченим автором статті Сучасна украӥнська поезія, але навіть соратниками О. Ольжича. Так, наприклад, О. Жданович (Штуль), немовби солідаризуючись із концепцією невідомого автора огляду, у статті 1947 р. 3 монументальною назвою Суворий $і$ великий запевняв:

Це не випадок, що великий батько став відомий під іменем О. Олесь, а великий син - О. Ольжич. Дві зовсім відмінні доби, дві зовсім різні тенденції і два зовсім окремі стилі. Тому й псевдоніми бринять протилежно ${ }^{24}$.

${ }^{23}$ O. Olzhych, Vybrani tvory..., s. 363-364.

${ }^{24}$ Ibidem, s. 470. 
Згодом у публікації 1953 р., патетично названій «Поезія нової доби», О. Жданович висловив думку, що О. Олесь не тільки «співець ніжних почувань», але і «зриву революції 1917 р.» Проте й далі протиставляв його творчість синовій та переконував, буцімто «О. Ольжич вже в своєму псевдонімі вносить інше звучання: звучання княжої броні» ${ }^{25}$, якось забуваючи, що саме О. Олесь автор поетичної збірки Княжа Украйна, написаної ще $1920 \mathrm{p}$.

Однак автентичні тексти О. Ольжича явно заперечують подібні твердження. Наприклад, у статті Украӥнська історична свідомість, опублікованій 1941 р., О. Ольжич також підкреслював мілітарний характер творчості батька, наголошуючи на єдності різних поколінь поетів у боротьбі за національну державу:

Тяжко йшло світочам XIX віку забити природний войовничий дух народу. Безсилі були вони теж проти основного героїчно-революційного спрямування поезії Шевченка і Лесі Українки з ії «гордощами у серці» і «одваги мечем двосічним». Вибухало це і в Олеся, іскрами розсипалося над Чупринкою: «не сокирою - мечем прорубано пущі дики». Пройшло двадцять літ, і мілітаризм опанував знову українську літературу і всю духовість. Не випадково ж меч увійшов у емблему нового українства ${ }^{26}$.

Таким чином, наведені лише окремі факти з автентичних текстів О. Ольжича вже явно заперечують його причетність до написання огляду Сучасна украйнська поезія. Також потрібно зазначити, що є чимало й інших аргументів, які підтверджують такий попередній висновок та потребують подальшого висвітлення в окремих публікаціях.

Зрештою, невідомо звідки взялася зараз уже фактично беззастережна ідея зарахування до публікацій О. Ольжича загалом доволі політично провокативного огляду Сучасна українська поезія, підписаного криптонімом А. Б., який для втаємничення

25 Ibidem, s. 18.

26 O. Olzhych, Poeziia. Proza..., s. 271-272. 
власних публікацій письменник начебто й не практикував. Та це знову ж таки (як і вже згадані) теми для окремих студій, зосібна ідейно-політичних.

\section{References}

Antonycz B. I., Poezja po tej stronie barykady, „Sygnały”, 1934, nr 4-5, s. 3-4.

Hordynskyi S., Na perelomi epokh. Literaturoznavchi statti, ohliady, esei, retsenzii, spohady, Lviv 2004.

Krupach M., Geneza tematyky ukrainskoi emihratsiinoi poezii 1920-1930-kh rokiv u interpretatsii B.I. Antonycha, "Spheres of culture", Volume V, Lublin 2013, s. $133-141$.

Krupach M., "Pershyi" ta "druhyi" poety "Prazkoi shkoly": problema avtentychnosti „svidchen avtorytetnykh myttsiv", "Pomiędzy. Mizh. Mezhdu. Between. Zwischen. Entre: Polonistyczno-Ukrainoznawcze Studia Naukowe”, Wrocław 2015, № 1, s. 219-232.

Olzhych O., Vybrani tvory, Kyiv 2009.

Olzhych O., Neznanomu Voiakovi, Kyiv 1994.

Olzhych O., Poeziia. Proza, Kyiv 2007. 
VI. Artykuły recenzyjne 


\section{Olha Morozova, Doslidzhennia istorii Ukrainy pershoi polovyny XX st. $v$ suchasnii polskii istoriohrafii: napriamky, kontseptsii, dyskusii, Vydavnytstvo CzNU im. Petra Mohyly, Mikolaiv 2020, ss. 432}

The study of Ukrainian history in the first half of the 20th century in contemporary Polish historiography: trends, concepts and discussions.

\section{Abstract:}

This paper analyses the state of contemporary Polish historiography about the history of Ukraine in the first half of the 20th century, a very dramatic period in Polish-Ukrainian relations, with a high emotional charge, influenced by political and ideological elements. Olha Morozova's book is an important voice in the historiographic Polish-Ukrainian discourse. The author indicates different aspects linking the history of both nations, but without passing over the difficult or even dramatic moments of their common history. The book enriches contemporary knowledge about Polish historical thought, prompts Ukrainian and Polish historians to reflect and perhaps reorient their findings and assessments. Olha Morozova takes the position of continuing the calm Polish-Ukrainian dialogue, eliminating the emotional and ideological elements as much as possible.

Keywords: history of Ukraine, the first half of the 20th century, Polish historiography.

Recenzowana książka, która była wydana przez Wydawnictwo Czarnomorskiego Uniwersytetu Narodowego im. Petra Mohyły w Mikołajowie, jest rozprawą habilitacyjną Olgi Morozowej, znanej badaczki zarówno na Ukrainie, jak również w Polsce. Olga Morozowa jest dyrektorką Ukraińsko-Polskiego Instytutu Naukowo-Badawczego 
w Mikołajowie, członkiem Towarzystwa Historiograficznego, które skupia polskich i ukraińskich historyków, była też uczestniczką letnich szkół języka i kultury polskiej. Dla swoich badań uzyskała wsparcie polskich instytucji, na przykład Fundacji im. Krzysztofa Skubiszewskiego. Autorka książki wielokrotnie uczestniczyła w międzynarodowych konferencjach w Polsce, a także była organizatorką wielu międzynarodowych konferencji na Ukrainie, w których licznie uczestniczyli polscy historycy.

Olga Morozowa podjęła bardzo istotny, a jednocześnie trudny problem badawczy. Badaczka zanalizowała stan współczesnej polskiej historiografii na temat dziejów Ukrainy w pierwszej połowie $\mathrm{XX}$ wieku, okresu bardzo dramatycznego w stosunkach polsko-ukraińskich o dużym ładunku emocjonalnym, gdzie oddziałują elementy polityczne i ideologiczne. Dzieje współżycia narodów polskiego i ukraińskiego charakteryzują się z jednej strony przykładami współpracy i kulturowym wzbogaceniem, jak również z drugiej strony wybuchami nieprzyjaznych działań, konfliktów. Monografia Olgi Morozowej może być bliska wszystkim, którzy stoją na stanowisku ukraińsko-polskiego dialogu i pojednania.

Olga Morozowa prowadziła szeroko zakrojone prace badawcze i analityczne, pracując na bogatym zestawie źródeł historiograficznych, jakie były pokłosiem badań naukowych i literatury popularnonaukowej historyków, przede wszystkim polskich, ale też ukraińskich, w ciągu ostatnich 30 lat. Niektóre z zagadnień dziejów polsko-ukraińskich były przedmiotem prac historiograficznych polskich historyków. ${ }^{1}$ Dość stwierdzić, że bibliografia monografii

1 Podam tylko publikacje dotyczące stosunków polsko-ukraińskich w latach 19171921: M. Dutkiewicz, Sojusz polsko-ukraiński 1920 roku w świetle polskiej historiografii [w:] Polska i Ukraina w walce o niepodległość 1918-1920, red. T. Krząstek, Warszawa 2009, s. 361-371; E. Koko, Sojusz Piłsudski-Petlura w polskiej historiografii, „Warszawskie Zeszyty Ukrainoznawcze”, t. 3, 1996, s. 305-314; M. Krotofil, Militarne aspekty stosunków polsko-ukrainskich z lat 1917-1921 $w$ świetle literatury polskiej [w:] Pratsi Ukrainsko-Polskoi komisii doslidzhennia vzaiemyn (1917-1921 rr.) / Prace Polsko-Ukraińskiej Komisji dla Badania Relacji Wzajemnych w latach 1917-1921, red. J. J. Bruski, W. Werstiuk, W. Skalski, t. 1, 
Olgi Morozowej zawiera aż 1959 pozycji. Oparcie się na podstawie solidnych źródeł historiograficznych prowadziło do właściwych analiz i wnioskowania, a także w konsekwencji do wyważonych ocen.

Zakres chronologiczny książki obejmuje lata 1989-2020. Właśnie pod koniec XX wieku, w kontekście przemian politycznych, rozpoczął się proces reorientacji stosunków ukraińsko-polskich, w tym trudnych problemów wspólnej przeszłości. Interesująca jest w związku z tym periodyzacja zaproponowana przez Olgę Morozową, która podzieliła ten okres na podokresy, przyjmując jako kryterium zmianę gabinetów politycznych i związane z tym kolejne modyfikacje polityki pamięci historycznej (lata 1989-1995, 1995-2000, 2000-2005, 2005-2007, 2007-2009, 2009-2015, 2015-2020). Wydaje się oczywiste, że w przypadku twórczości historycznej na temat dziejów Ukrainy w pierwszej połowie XX wieku, a zwłaszcza stosunków polsko-ukraińskich w tym czasie, narosłych emocji, ideologizacji problematyki, przyjęta periodyzacja jest właściwa.

Konstrukcja książki jest prawidłowa, pozwalająca na realizację postawionego celu, czyli przedstawienia badań dziejów Ukrainy w pierwszej połowie XX wieku we współczesnej historiografii polskiej. Książka składa się z następujących elementów (poszczególne tytuły podam w tłumaczeniu): wykazu skrótów, wprowadzenia, pięciu rozdziałów (I. Historiograficzne, źródłoznawcze i metodologiczne aspekty badania; II. Współczesna polska ukrainistyka: instytuty, periodyki, personalia; III. Problemy historii Ukrainy pierwszych dziesięcioleci XX w. we współczesnej polskiej historiografii; IV. Problematyka ukraińska okresu międzywojnia we współczesnych polskich badaniach naukowych; V. Problemy stosunków ukraińsko-polskich lat 1939-1947 we współczesnej polskiej historiografii), wniosków, streszczenia w języku polskim, streszczenia w języku

Kijów 2019, s. 169-179; J. Pisuliński, Polityczne relacje polsko-ukraińskie 19171921 w badaniach polskich historyków [w:] Pratsi Ukrainsko-Polskoi komisii doslidzhennia vzaiemyn (1917-1921 rr.) / Prace Polsko-Ukraińskiej Komisji dla Badania Relacji Wzajemnych w latach 1917-1921, red. J. J. Bruski, W. Werstiuk, W. Skalski, t. 1, Kijów 2019, s. 49-72. 
angielskim, bibliografii, biografii wybranych polskich ukrainoznawców, indeksu nazwisk. Każdy rozdział składa się z trzech podrozdziałów. $\mathrm{W}$ tytułach rozdziałów niepotrzebne są powtórzenia, zawarte przecież w tytule głównym książki. Rozumiem jednak, że może to wynikać $\mathrm{z}$ konwencji pisania prac kwalifikacyjnych na Ukrainie.

W rozdziale pierwszym Olga Morozowa zanalizowała aspekty historiograficzne, źródłowe i metodologiczne, a także przedstawiła założenia monografii. Jej zdaniem krytyczne podejście do wspólnej przeszłości urozmaiciło dyskurs naukowy między polskimi i ukraińskimi historykami, wzbogaciło problematykę badawczą. Znaczący wkład do rozumienia problemu w polskim środowisku intelektualnym wniósł orędownik porozumienia i współpracy polsko-ukraińskiej Jerzy Giedroyć, co w swoich wcześniejszych badaniach mocno podnosiła Olga Morozowa. ${ }^{2}$ Istotny wpływ na ukształtowanie się wizji stosunków polsko-ukraińskich miał także list Bohdana Osadczuka do Lecha Wałęsy z 1993 r. Bohdan Osadczuk (1920-2011) był ukraińskim publicystą i dziennikarzem, sowietologiem, badaczem historii Europy Środkowo-Wschodniej, który blisko współpracował na emigracji z Jerzym Giedroyciem i innymi polskimi intelektualistami. Poczesne miejsce w poszukiwaniu wspólnych ocen przeszłości zajęła Polsko-Ukraińska Komisja Historyków. Punktem zwrotnym w badaniu wspólnej przeszłości było powstanie ośrodków naukowych, takich jak Fundacji św. Włodzimierza Chrzciciela Rusi Kijowskiej w Krakowie, Południowo-Wschodniego Instytutu Naukowego w Przemyślu, Instytutu Europy Środkowo-Wschodniej w Lublinie i innych.

W rozdziale drugim Olga Morozowa charakteryzuje wkład poszczególnych instytucji naukowo-badawczych w rozwój problematyki dziejów Ukrainy w pierwszej połowie XX w., a także osiągnięcia w tym zakresie poszczególnych naukowców, takich jak: Władysław Andrzej Serczyk, Jarosław Moklak, Andrzej Nowak, Eugeniusz Koko, Grzegorz Motyka, Stanisław Stępień, Rafał Wnuk, Jerzy Maternicki, Aleksander Smoliński i inni. Autorka podkreśliła rolę twórczości

2 O. Morozowa, Ideia nezalezhnoi Ukrayiny v diialnosti Ezhy Gedroitsia, „Naukovi Pratsi”, t. 274, 2016, s. 75-79. 
i wysiłków organizacyjnych polskich historyków ukraińskiego pochodzenia: Roman Drozd, Emilian Wiszka, Bohdan Halczak, Igor Hałagida, Rościsław Żerelik, Aleksander Kolańczuk, Stefan Kozak, Grzegorz Kuprianowicz, Włodzimierz Mokry i inni. Uzupełniają tę listę przedstawiciele Polonii: Jerzy Giedroyć i inni. Nie byli oni wprawdzie profesjonalnymi historykami, ale ich głos był istotny dla świadomości historycznej Polaków, odbierany przez szerokie rzesze publiczności. Olga Morozowa porównawczo zanalizowała też dokonania historyków ukraińskich w problematyce pierwszej połowy XX w.: Leonida Zaszkilniaka, Jarosława Kałakury, Mykoły Lytwyna, Ihora Iliuszyna, Wołodymyra Komara, Jarosława Hrycaka, Mykoły Henyka, Jewhena Sinkiewicza, Witalija Telwaka, Natalii Jakowenko i innych. W monografii znalazła też miejsce analiza twórczości diaspory ukraińskiej reprezentowanej przez twórczość Romana Koropeckiego, Grigorija Grabowicza (George Gregory Grabowicz), Tarasa Hunczaka, Bohdana Osadczuka, Wołodymyra Kosyka, Romana Szporluka i innych. Olga Morozowa proponuje także czytelnikom próbę prozopograficznego portretu współczesnych polskich ukrainoznawców.

W monografii dużo uwagi poświęcono analizie czasopism naukowych, które są ważnym narzędziem szerzenia zainteresowania przeszłością narodu ukraińskiego na arenie międzynarodowej. Olga Morozowa szczególne miejsce przyznała polskim czasopismom wydawanym na emigracji, czyli „Kulturze” i „Zeszytom Historycznym”. Dzięki tym pismom idee poszanowania tożsamości innych narodów przenikały do polskiej publiczności, co pozytywnie wpłynęło na atmosferę w duchu pojednania narodów polskiego i ukraińskiego.

W pozostałych rozdziałach Olga Morozowa skoncentrowała się na wielu kontrowersyjnych problemach w stosunkach polsko- ukraińskich, w ujęciu których istnieją zasadnicze różnice między autorami polskimi i ukraińskimi. W szczególności są to: powstanie Zachodnioukraińskiej Republiki Ludowej i wojna polsko-ukraińska 1918-1919, działalność Organizacji Ukraińskich Nacjonalistów i Ukraińskiej Powstańczej Armii, tragedia wołyńska (rzeź wołyńska), powojenne wysiedlenia Polaków i Ukraińców, operacja „Wisła” i inne. 
W tym kontekście Olga Morozowa zanalizowała stanowiska i oceny funkcjonujące w historiografii polskiej i ukraińskiej w sposób wyważony, nie pomijając jednak kontrowersyjnych zagadnień. Na przykład opisując wydarzenia na Wołyniu polscy badacze koncentrują się na ich bezpośrednich przyczynach. Natomiast większość ukraińskich i część polskich historyków rozważa problem znacznie szerzej i jako jedną z głównych przyczyn konfrontacji polsko-ukraińskiej wskazuje dyskryminacyjną politykę władz polskich wobec Ukraińców w latach przedwojennych. Trwa również dyskusja na temat liczby ofiar. Narracja ma często emocjonalny charakter. Dyskurs historiograficzny był często wykorzystywany do osiągnięcia określonych celów politycznych, a wypracowane przez historyków koncepcje i paradygmaty odegrały ważną rolę w kształtowaniu ideologii państwowej i społecznej.

W obszernych wnioskach Olga Morozowa przedstawiła najważniejsze analizy i uogólnienia o ostatecznym charakterze, istotne dla współczesnego rozumienia procesu historiograficznego w Polsce i perspektyw badań na przyszłość. Bardzo dobrze, że autorka we wnioskach przedstawiła rekomendacje dotyczące węzłowych tematów do przyszłych badań polskich i ukraińskich historyków w zakresie dziejów Ukrainy w pierwszej połowie XX w. Na szczególne uznanie zasługują propozycje dotyczące sposobów intensyfikacji ukraińsko-polskiego dialogu historyków w celu otwartego i produktywnego zrozumienia kluczowych zagadnień wspólnej historii Ukrainy i Polski. Aby dyskurs polsko-ukraiński był bardziej otwarty i produktywny Olga Morozowa uznała, że należy kontynuować dyskusję na temat węzłowych zagadnień historii Ukrainy pierwszej połowy XX wieku w ramach konferencji, kongresów, publikacji etc., także angażować się we wspólne badania interdyscyplinarne, poszukiwanie wspólnych rozwiązań w podejściu do analizy wydarzeń. Konieczne jest oparcie się o obiektywizm i naukowość, pluralizm podejść i chęć zrozumienia innych, promowanie odpolitycznienia, demitologizacji i destereotypizacji ocen. Należy zatem unikać nadmiernego akcentowania negatywnych aspektów stosunków ukraińsko-polskich, zaś $\mathrm{w}$ większym stopniu podkreślać wspólne pozytywne doświadczenia 
historyczne (na przykład układ Józefa Piłsudskiego i Symona Petlury). Wreszcie byłoby dobrze przejść do budowania międzysąsiedzkiej polsko-ukraińskiej pamięci w oparciu o zrozumienie i przebaczenie, pamiętając, że historia powinna być czynnikiem jednoczącym, a nie narzędziem wzniecania nowych konfliktów.

Niewątpliwie książka Olgi Morozowej jest ważnym głosem w historiograficznym dyskursie polsko-ukraińskim, co znajduje potwierdzenie $\mathrm{w}$ opublikowanych $\mathrm{w}$ tak krótkim czasie recenzji w periodykach ukraińskich. ${ }^{3}$ Autorka wskazała zarówno na aspekty łączące historię obu narodów, ale bez przemilczania trudnych, czy wręcz dramatycznych, momentów wspólnej historii. Nauka historyczna (o ile historia jest nauką, a nie literaturą) ma charakter idiograficzny, nie zaś nomotetyczny, stąd wielość faktów, postaw, stanowisk etc. Czy uda się sprowadzić polsko-ukraiński dyskurs historiograficzny do poziomu imputacji kulturowej, bez elementów ideologicznych? Nie wydaje mi się to możliwe w najbliższej przyszłości. Można nawet stwierdzić, że jestem w tym mniej optymistycznie nastawiony niż Olga Morozowa, aczkolwiek oczywiście naszą rolą jako historyków jest przyjęcie postawy obiektywizmu i neutralności.

Podsumowując, Oldze Morozowej udało się przygotować poważne opracowanie naukowe, które wzbogaca współczesną wiedzę o polskiej myśli historycznej, skłania ukraińskich i polskich historyków do refleksji, a być może do reorientacji swoich ustaleń i ocen na historię Ukrainy w pierwszej połowie XX w. Z całą pewnością Olga Morozowa stoi na stanowisku kontynuacji spokojnego dialogu polsko-ukraińskiego, maksymalnie eliminując elementy emocjonalne i ideologiczne.

${ }^{3}$ I. Romaniuk [rec.], Morozova O. Doslidzhennia istorii Ukrainy pershoi polovyny $X X$ st. $v$ suchasnii polskii istoriohrafi: napriamky, kontseptsii, dyskusii, CHNU im. P. Mohyly, Mykolaiv 2020, 431 s.; „Naukovi zapysky VDPU imeni Mykhaila Kotsiubynskoho", Seria: Istoriia, Vinnytsia 2020, s. 118-120; N. I. Zemziulina [rec.] Morozova O. S. Doslidzhennia istorii Ukrainy pershoi polovyny XX st. v suchasnii polskii istoriohrafi: napriamky, kontseptsii, dyskusii: monohrafiia, CHNU im. P. Mohyly, Mykolaiv 2020, 432 s.; „Visnyk Cherkaskoho universytetu”, Seriia: Istorychni nauky, nr 1, 2020, s. 177-178. 


\section{References}

Dutkiewicz M., Sojusz polsko-ukraiński 1920 roku w świetle polskiej historiografii [w:] Polska i Ukraina w walce o niepodległość 1918-1920, red. T. Krząstek, Warszawa 2009, s. 361-371.

Koko E., Sojusz Piłsudski-Petlura w polskiej historiografii, „Warszawskie Zeszyty Ukrainoznawcze", t. 3, 1996, s. 305-314.

Krotofil M., Militarne aspekty stosunków polsko-ukraińskich z lat 1917-1921 w świetle literatury polskiej [w:] Pratsi Ukrainsko-Polskoi komisii doslidzhennia vzaiemyn (1917-1921 rr.) / Prace Polsko-Ukraińskiej Komisji dla Badania Relacji Wzajemnych w latach 1917-1921, red. J. J. Bruski, W. Werstiuk, W. Skalski, t. 1, Kijów 2019, s. 169-179.

Morozowa O., Ideia nezalezhnoi Ukrayiny v diialnosti Ezhy Gedroitsia, „Naukovi Pratsi”, t. 274, 2016, s. 75-79.

Pisuliński J., Polityczne relacje polsko-ukraińskie 1917-1921 w badaniach polskich historyków [w:] Pratsi Ukrainsko-Polskoi komisii doslidzhennia vzaiemyn (1917-1921 rr.) / Prace Polsko-Ukraińskiej Komisji dla Badania Relacji Wzajemnych w latach 1917-1921, red. J.J. Bruski, W. Werstiuk, W. Skalski, t. 1, Kijów 2019, s. 49-72.

Romaniuk I. [rec.], Morozova O. Doslidzhennia istorii Ukrainy pershoi polovyny XX st. v suchasnii polskii istoriohrafii: napriamky, kontseptsii, dyskusii, CHNU im. P. Mohyly, Mykolaiv 2020, 431 s.; „Naukovi zapysky VDPU imeni Mykhaila Kotsiubynskoho", Seria: Istoriia, Vinnytsia 2020, s. 118-120.

Zemziulina N. I. [rec.] Morozova O. S. Doslidzhennia istorii Ukrainy pershoi polovyny XX st. $v$ suchasnii polskii istoriohrafii: napriamky, kontseptsii, dyskusii: monohrafiia. CHNU im. P. Mohyly, Mykolaiv 2020, 432 s.; „Visnyk Cherkaskoho universytetu", Seriia: Istorychni nauky, 2020, nr 1, s. 177-178. 


\title{
Mariusz R. Drozdowski
}

\section{Historia wojen domowych w Polsce Alberta Viminy, w przekładzie Krzysztofa Żaboklickiego, pod redakcją, ze wstępem i komentarzami Teresy Chynczewskiej-Hennel, Instytut Badań nad Dziedzictwem Kulturowym Europy, Białystok 2017, ss. 284}

\begin{abstract}
:
The review concerns an edition of Albert Vimina's work History of civil wars in Poland (Historia delle guerre civili in Polonia) by Teresa Chynczewska-Hennel. The edition consists of two main parts. The first, which is an extensive introduction, was devoted mainly to the description of Albert Vimina's biography. The second part contains The History of Civil Wars in Poland, which consists of five books on 196 pages. The main part contains descriptions of the struggles of the Polish-Lithuanian Commonwealth with the Zaporizhian Cossacks in the years 1648-1651. The following three parts, attached to The History of Civil Wars in Poland, are also related to the author's personal observations. As I have already mentioned, the reviewed edition is published in Poland for the first time and it has been prepared with knowledge of editorial art and in accordance with the recommendations of the publishing manual. It must be emphasized at this point that what clearly distinguishes it from the Lithuanian edition from 2012 is, above all, the excellent translation and extensive set of footnotes. In conclusion, it must be said with certainty that we have received a very successful edition and, what is worth emphasizing, not the last one in the publisher's output.
\end{abstract}

Keywords: Vimina, war, Commonwealth, Ukraine, Cossack, Khmelnytsky Uprising. 
$\mathrm{Z}$ uwagi na wciąż istniejące wcale niemałe zainteresowanie tak historyków polskich, jak zagranicznych oraz spoZZZrego grona czytelników dziejami Ukrainy i stosunkami polsko - ukraińskimi, pojawienie się na rynku wydawniczym dzieła Alberta Viminy Historia wojen domowych $w$ Polsce musi budzić zainteresowanie.

Rzeczone dzieło przedstawiające wnikliwy obraz wojny Rzeczypospolitej z Kozaczyzną pod wodzą Bohdana Chmielnickiego, jest wspaniałym źródłem, które w znaczący sposób wzbogaca naszą dotychczasową wiedzę o tym wydarzeniu stanowiącym trudną i bolesną kartę w historii obu narodów.

Decyduje o tym przede wszystkim fakt, że zawarte w nim ciekawe spostrzeżenia Viminy, są wynikiem jego osobistych doświadczeń i obserwacji, które niewątpliwie spisywał w trakcie podejmowanych przez siebie misji. Przytacza więc na kartach utworu wiele interesujących rozmów przeprowadzonych ze znaczącymi osobami w Rzeczypospolitej. Opisuje obrady Sejmu, charakteryzuje kraj, zwyczaje, stosunki społeczne i wiele innych spraw. Zapoznaje Vimina czytelnika nie tylko z przebiegiem wydarzeń, ale też stara się zrozumieć ich przyczyny. Dopuszcza do głosu przedstawicieli obu walczących w powstaniu Chmielnickiego stron. Dostrzega tło europejskie w opisie konfliktu, uważa bowiem, iż powstanie Kozaczyzny to nie tylko, jego zdaniem, walka o narodowe i społeczne prawa Ukrainy, ale niestety konflikt Słowiańszczyzny prawosławnej z rzymskokatolicką. Spogląda na powstanie Chmielnickiego poprzez pryzmat dwóch kultur: zachodniej powiązanej z Rzymem, i wschodniej związanej z Bizancjum.

Dlatego też należy wyrazić radość, że na wydanie tego dzieła po raz pierwszy w Polsce zdecydowała się Teresa Chynczewska-Hennel. Edycji - co nie pozostaje bez znaczenia - podjęła się autorka wielu cenionych prac naukowych ${ }^{1}$, znamienita badaczka

1 T. Chynczewska-Hennel, Świadomość narodowa szlachty ukrainskiej i Kozaczyzny od schyłku XVI do połowy XVII w., PWN, Warszawa 1985; eadem, Rzeczpospolita XVII wieku w oczach cudzoziemców, Zakład Narodowy im. Ossolińskich, Wrocław 1993; Między sobą. Szkice historyczne polsko-ukraińskie, 
historii Ukrainy w dobie nowożytnej jak również dziejów kultury staropolskiej.

Recenzowana praca składa się ze wstępu, czterech części, na które składają się: Historia wojen domowych w Polsce, Krótka relacja o sukcesach oręża Moskali przeciw Polakom na Litwie, Relacja o państwie moskiewskim, Szwecja, bibliografii, indeksu osobowego. Dobre wrażenie pozostawia również forma edytorska niniejszej książki.

Niniejsze wydanie składa się z dwóch zasadniczych członów. Pierwszy, będący obszernym wstępem, został poświęcony w głównej mierze opisowi życiorysu Alberta Viminy. Chynczewska-Hennel nie koncentruje się na samej faktografii, lecz w oparciu o źródła archiwalne, drukowane oraz bogatą literaturę przedmiotu, analizuje najistotniejsze wątki aktywności dyplomatycznej Autora Historii wojen domowych $w$ Polsce, a także szczegółowo ukazuje jego osiągnięcia.

Dowiadujemy się zatem, że Alberto Vimina, którego prawdziwe imię i nazwisko brzmiało Michele Bianchi, przypuszczalnie około 1648 roku pojawia się w Warszawie, gdzie znajduje opiekuna w osobie nuncjusza Stolicy Apostolskiej w Rzeczypospolitej Giovanniego de Torresa, który pełnił swą misję w latach 1645-1652 (s. VIII). To właśnie ów nuncjusz wskazał na Alberta Viminę jako na najodpowiedniejszą osobę nadającą się do wyjazdu na Ukrainę. W końcu maja 1650 roku - jak dowodzi T. Chynczewska-Hennel - Vimina znalazł się we Lwowie a następnie 3 czerwca dotarł do Czehrynia, siedziby Chmielnickiego (s. XI).

W bardzo interesujący sposób zostało ukazane spotkanie dyplomaty z przywódcą powstania kozackiego. Przebiegało ono jak czytamy - w dobrej atmosferze. W odpowiedzi na złożoną przez Viminę propozycję walki przeciwko Turkom, Chmielnicki stwierdził, że:

red. T. Chynczewska-Hennel, N. Jakowenko, Instytut Europy Środkowo-Wschodniej, Lublin 2000; eadem, Nuncjusz i król. Nuncjatura Maria Filonardiego w Rzeczypospolitej 1636-1643, Wydawnictwo Neriton - Instytut Historii PAN, Warszawa 2006; eadem, One World - Many Colours, Zakład Wydawniczy Nomos, Kraków 2019. 
[...] jego ludzie mogliby wyruszyć na Morze Czarne, ale pod dwoma warunkami. Tatarzy powinni zerwać sojusz z Portą zaś król Jan Kazimierz udzielić swego zezwolenia Chmielnicki stwierdził ponadto, iż musi przemyśleć możliwości organizacyjne podjęcia takiej wojny. Przypomniał także o obietnicach finansowych Władysława IV. Zaproponował ponowne spotkanie z Viminą w Czehryniu, po jego konsultacjach z mocodawcą. (s. XI)

Jak trafnie konkludowała T. Chynczewska-Hennel, wenecki wysłannik, po dwóch spotkaniach odbytych z Chmielnickim oraz rozmowach $z$ innymi osobami, zdał sobie sprawę, że wrogość Kozaków wobec Polski byłaby trudna do załagodzenia.

Ciekawie wypadają także fragmenty opisujące kolejną misję dyplomatyczną Viminy. Autorka podkreśla, że w listopadzie 1654 roku zaoferował on swe usługi dyplomatyczne Senatowi Najjaśniejszej Republiki Wenecji proponując wyjazd do Moskwy w celu pozyskania pomocy do walki przeciwko potędze otomańskiej. Rzeczona propozycja została zaakceptowana, albowiem na co słusznie zwraca uwagę T. Chynczewska-Hennel:

W Wenecji stracono nadzieję na uzyskanie pomocy Polski i przemyśliwano poważnie strategie w oparciu o ewentualne działanie Kozaków zaporoskich i dońskich przeciwko Turcji zabezpieczającej planowaną blokadę Konstantynopola. (s. XV)

Odnotowując poszczególne etapy podróży Viminy do Rosji, Autorka podkreśla, że Vimina, ominąwszy rosyjsko-polski teatr wojenny dzięki popłynięciu statkiem z Travemünde do Rewala, 6 sierpnia przybył do Smoleńska, gdzie oczekiwał nadaremnie przyjazdu cara Aleksego Michajłowicza. Wyjechał także - jak kontynuuje T. Chynczewska-Hennel - poza Smoleńsk w kierunku granicy z Litwą do Borysowa, gdzie miał kolejny raz nadzieję na spotkanie z carem, do którego ostatecznie nie doszło. Pobyt Viminy w Rosji - co zauważa Autorka - zaowocował pierwszą wersją jego relacji o Moskwie nazwanej Breve racconto dei profitti dell'armi de Moscovitii contra Polonia in Lituania i Relatione della Moscovia.

W tym ustępie książki odnajdujemy także drobiazgową charakterystykę dzieła Viminy, jego ocenę w dotychczasowej historiografii oraz omówienie uprzednich edycji. Nie sposób nie przywołać w tym 
miejscu fragmentu wypowiedzi Autorki na temat walorów poznawczych wspomnianego utworu:

Zapoznaje Vimina czytelnika nie tylko z przebiegiem wydarzeń, ale też stara się zrozumieć ich przyczyny. Dopuszcza do głosu przedstawicieli obu walczących w powstaniu Chmielnickiego stron. Dostrzega tło europejskie w opisie konfliktu, uważa bowiem, iż powstanie Kozaczyzny to nie tylko, jego zdaniem, walka o narodowe i społeczne prawa Ukrainy, ale niestety konflikt Słowiańszczyzny prawosławnej z rzymskokatolicką. Spoglądał na powstanie Chmielnickiego poprzez pryzmat dwóch kultur: zachodniej powiązanej z Rzymem, i wschodniej związanej z Bizancjum. (s. XVIII)

Człon drugi wypełnia Historia wojen domowych $w$ Polsce, która składa się z pięciu ksiąg umieszczonych na 196 stronach. Główna część zawiera opisy zmagań Rzeczypospolitej Obojga Narodów z Kozaczyzną zaporoską w latach 1648-1651.

Początek pierwszej księgi rozpoczyna się od opisu niezwykłych zjawisk przyrodniczych, które miały zapowiadać nieszczęścia wojenne oraz śmierci króla Władysława IV. Ukazane zostały też klęski wojsk koronnych w bitwach pod Żółtymi Wodami, Korsuniem i Piławcami a także inne wypadki do końca roku 1648 . To w tym fragmencie dzieła znajdujemy informację na temat pochodzenia społecznego Chmielnickiego, która jak niegdyś słusznie zauważył Janusz Kaczmarczyk ${ }^{2}$, może być kluczem do rozwikłania zagadki rodowodu przywódcy powstania:

O Chmielnickim barbarzyńcy nie należącym do polskiej szlachty, wiadomo jednak, że przyszedł na świat w dość zacnej rodzinie. Jak mówią, ojciec jego był litewskim szlachcicem, który schronił się na Zaporożu uciekając przed wymierzoną mu przez sądy karą zwaną przez Polaków infamią, oznaczającą utratę szlachectwa. (s. 13)

Interesujące pozostają także wypowiedzi odnośnie wojskowości Kozaków czy wyznawang przez nich religii (s. 15). Księga druga

2 Zob. J. Kaczmarczyk, Bohdan Chmielnicki, wyd. 2, Zakład Narodowy im. Ossolińskich, Wrocław 2007, s. 16-17. 
rozpoczyna się od wydarzeń związanych z inauguracją 1649 roku i koronacją Jana Kazimierza. Następna jej część przynosi m.in. omówienie dyplomatycznych kontaktów i negocjacji, których celem było zawarcie pokoju między walczącymi stronami, toczących się w czerwcu tego roku obrad senatorów zdominowanych sprawami związanymi ze spodziewaną wojną z Kozakami czy chociażby pierwszej fazy kampanii 1649 r. (ss. 65-98).

Uwadze Viminy nie umknęły także działania zbrojne jakie toczyły się na Litwie późnym latem i jesienią 1648 r. Wzmiankuje więc zarówno o klęsce Hrehorego Mirskiego w bitwie pod Horwolem a także o zdobyciu i spaleniu przez niego Pińska. Przytoczmy tu jakże bardzo plastyczny opis tego ostatniego z rzeczonych wydarzeń:

Mirski zauważywszy, że ich ogień odnosi skutek, rozkazał kilku drużynom niemieckich muszkieterów podejść pod szaniec: część z nich brała na cel ukazujących się na nim ludzi, inni podczołgiwali się coraz bliżej. Obrońcy zaczynali tracić odwagę i nadzieję na przetrwanie, więc muszkieterom udało się jako pierwsi wejść na wały. [...] Miasto i obóz w nieładzie zapełniły się litewskim wojskiem, rozpoczęła się straszliwa rzeź, gdyż Mirski pałał żądzą zemsty za klęskę nad Orilem1, pragnął przelewu nieprzyjacielskiej krwi. Aby cios stał się jeszcze dotkliwszy, kazał podłożyć pod kilka budynków ogień, który rozprzestrzenił się szybko, bo wszystko było z drewna, i tak spłonęło wkrótce całe miasto. (ss. 72-73)

Księgę trzecią otwierają opisy związane z opuszczeniem przez króla Warszawy w dniu 24 czerwca 1649 r. i marszem w kierunku Ukrainy. Rozważania Viminy koncentrują się tu w głównej mierze na kwestiach wiążących się z odsieczą Jana Kazimierza oblężonemu przez Kozaków i Tatarów Zbarażowi, obroną Zbaraża, bitwą pod Zborowem czy wreszcie ugodą zborowską. Godne podkreślenia w tym fragmencie pracy jest zamieszczenie jak najbardziej trafnej oceny zawartego pod Zborowem porozumienia między Rzeczypospolita a Kozaczyzną. W ocenie Viminy, jego postanowienia niesatysfakcjonowany żadnej ze stron ${ }^{3}$ :

3 Podobnego zdania na temat ugody zborowskiej był W. A. Serczyk, Na płonacej Ukrainie. Dzieje Kozaczyzny 1648-1651, Warszawa 1998, s. 265-267. 
Kozacy żałowali [...] zawarcia pokoju, gdyż wymknęło im się z rąk pewne, wspaniałe zwycięstwo, dzięki któremu mogli stać się sławni, Polsce zaś dyktować prawa. Także Polacy żalili się gorzko, że zawarty został pokój tak haniebny, pozwalający spragnionemu krwi szlacheckiej, chciwemu zemsty, żądnemu łupów barbarzyńcy zachować potężną armię, co sprawia, że wiszące nad Rzeczpospolitą niebezpieczeństwo nie ustaje, a tylko odsuwa się w czasie. Ruś nie jest bynajmniej zwyciężona, pozostaje pod bronią zwrócona przeciw Polsce, Kozacy zyskali Zaporoże i godność hetmańską, schizmatycy stają na czele wyżej wymienionych województw pełnych wojowników, koni, bydła wszelkiego rodzaju, gdzie ziemia nader urodzajna dostarcza wszystkiego, czego człowiekowi potrzeba. Nieszczęściem było na dodatek to, że Tatarzy przekonawszy się o korzyściach, jakie przynosi im sojusz z Kozakami, skuszeni perspektywą łupu gotowi będą im pomoc za każdym razem, gdy ci chwycą za broń. Rzeczpospolita nie stała się zatem bezpieczniejsza, jest też jeszcze bardziej podzielona, gdyż wzrosły siły stronnictwa schizmatyków, które starać się będzie pozyskać sobie innych dysydentów, do czego już dochodziło na wszystkich sejmach w przeszłości. (s. 125)

Księgę czwartą inauguruje opis sejmu listopadowego 1649 roku. Wśród pozostałych, poruszanych w niej, wątków szczególnie cenne jest dość obszerne omówienie przebiegu poselstwa braci Puszkinów, które przybyło do Warszawy w marcu 1650 r. Vimina, analizując chociażby wysunięte przez wysłanników cara moskiewskiego żądania ${ }^{4}$, jak najbardziej trafnie odnotowuje, że:

Te niestosowne, oparte na tak bardzo wątłych podstawach roszczenia zmierzały najwyraźniej do wypowiedzenia wojny. Uznano wprawdzie, że nie są całkiem niedorzeczne przyczyny, z których Moskale się skarżą, lecz zuchwałość ich żądań sprawiła, że nie zechciano zastanowić się nad środkami, które mogłyby ich zadowolić. Nie żądali oni zadośćuczynienia za zniewagi, pragnęli zemsty,

${ }^{4}$ Domagano się m.in. zapłacenia 500000 węgierskich dukatów jako rekompensaty za omyłki w tytulaturze cara i za wydawanie książek znieważających naród moskiewski oraz „[...] zwrotu Smoleńska, księstwa siewierskiego i wszystkich ziem zajętych swego czasu wraz z nimi przez Zygmunta III i Władysława I", Historia wojen domowych $w$ Polsce Alberta Viminy, w przekładzie Krzysztofa Żaboklickiego, pod redakcją, ze wstępem i komentarzami Teresy Chynczewskiej-Hennel, Instytut Badań nad Dziedzictwem Kulturowym Europy, Białystok 2017, s. 157. 
a za pominięcie tytułów domagali się zwrotu krainy tak rozległej, że na mniejszym obszarze mieści się wiele europejskich królestw. (s. 157)

W dalszej partii księgi Autor wspomina także o wyprawie kozacko-tatarskiej do Mołdawii, której przyczyn upatruje gównie w przyjaznym stosunku „[...] wojewody do Polaków; nie popierał on ich otwarcie orężem, lecz pomagał potajemnie swoimi radami i dostarczaniem wielu ważnych wiadomości o zamiarach i ruchach Kozaków" (s. 164).

Piąta i ostatnia księga zamyka wydarzenia zmagań Rzeczypospolitej z powstaniem Chmielnickiego na początku 1652 roku. Niezmiernie atrakcyjne są tu obserwacje Autora na temat rozpoczętej w lutym 1651 r. nowej wojny między Rzecząpospolitą a Kozaczyzną, a także na jej moment zwrotny, którym była bitwa pod Beresteczkiem. Na dowód tego przywołajmy tu przynajmniej fragment opisu zmagań pod wspomnianym Beresteczkiem w dniu 30 czerwca 1651 r.:

Trzydziestego rankiem uszykowano więc wojsko do bitwy i skierowano w tamtą stronę strażnika Houwaldta, Niemca, wraz z Wolfem, kapitanem królewskiej gwardii i kilkoma armatkami, a za nimi w dobrym porządku więcej wojska przeznaczonego do wykonania przedsięwzięcia. Na wzgórzu przebywało wtedy kilka tysięcy Tatarów nie wiadomo, czy po to, aby je strzec, czy też po to, aby stamtąd wyruszyć na jakiś wypad. Na widok zbliżających się polskich żołnierzy wyrzekli się oni stawiania oporu i nie czekając nawet, aż zagrzmią muszkiety, nie tyle wycofali się, co uciekli na równinę. Zająwszy wzgórze Polacy zaczęli natychmiast strzelać z owych armatek. Dwóch tatarskich dostojników ugodzonych jedną kulą padło trupem u stóp chana, znajdującego się tam przez przypadek lub w celu zaprowadzenia porządku wśród tych, którzy wzgórze opuścili. Przerażony tym zdarzeniem chcąc uniknąć niebezpieczeństwa ruszył on galopem; zobaczyli to barbarzyńcy i pomyśleli, że ucieka, więc równie szybko za nim popędzili. Strach ogarnął nie tylko stojących najbliżej, pogłoska o ucieczce władcy rozeszła się szybko i wszyscy rzucili się tam, gdzie wydało im się, że będą bezpieczn.i (s. 188)

Następne trzy części dołączone do Historii wojen domowych $w$ Polsce, wiążą się również z osobistymi obserwacjami Autora. Krótka relacja o sukcesach oręża Moskali przeciw Polakom na Litwie opisuje wojnę z Moskwą w latach 1654-1655, która spowodowana została 
konfliktem z Kozaczyzną. Kolejny fragment to Relacja o państwie moskiewskim, w której Vimina opisuje położenie, klimat, obyczaje, religię, sposób sprawowania władzy, przedstawia charakterystykę Rosji połowy XVII wieku. Ostatnią część książki stanowi z kolei opis Szwecji, którą odwiedził w swej podróży w roku 1653.

Jak już wspomniałem recenzowana edycja ukazuje się w Polsce po raz pierwszy i została opracowana ze znajomością sztuki edytorskiej oraz zgodnie z zaleceniami instrukcji wydawniczej. Trzeba w tym miejscu podkreślić, że to, co wyraźnie odróżnia ją od wydania litewskiego z 2012 r. to przede wszystkim doskonałe tłumaczenie oraz rozbudowany aparat przypisów.

Profesjonalnego przekładu z języka włoskiego dokonał Krzysztof Żaboklicki, profesor filologii włoskiej Uniwersytetu Warszawskiego, w latach 1991-2004 dyrektor Stacji Polskiej Akademii Nauk w Rzymie, uznany tłumacz Machiavellego oraz współczesnych pisarzy włoskich, między innymi Umberto Eco.

W 408 przypisach zostały natomiast umieszczone wyjaśnienia oraz informacje uzupełniające odnośnie występujących w tekście osób, nazw geograficznych, wydarzeń, co umożliwi mniej obeznanemu w materii czytelnikowi łatwiejszy odbiór i zrozumienie dzieła.

Kończąc należy z całą mocą stwierdzić, że otrzymaliśmy niezwykle wartościową i udaną edycję i co warto zaakcentować nie ostatnią w dorobku Wydawcy

\section{References}

Historia wojen domowych w Polsce Alberta Viminy, w przekł. K. Żaboklickiego, red., ze wstępem i komentarzami T. Chynczewskiej-Hennel, Instytut Badań nad Dziedzictwem Kulturowym Europy, Białystok 2017.

Chynczewska-Hennel T., Świadomość narodowa szlachty ukraińskiej i Kozaczyzny od schyłku XVI do połowy XVII w., PWN, Warszawa 1985.

Chynczewska-Hennel T., Rzeczpospolita XVII wieku w oczach cudzoziemców, Zakład Narodowy im. Ossolińskich, Wrocław 1993.

Chynczewska-Hennel T., Jakowenko N., Między sobą. Szkice historyczne polsko-ukraińskie, Instytut Europy Środkowo-Wschodniej, Lublin 2000. 
Chynczewska-Hennel T., Nuncjusz i król. Nuncjatura Maria Filonardiego w Rzeczypospolitej 1636-1643, Wydawnictwo Neriton, Warszawa 2006.

Chynczewska-Hennel T., One World - Many Colours, Zakład Wydawniczy Nomos, Kraków 2019.

Kaczmarczyk J., Bohdan Chmielnicki, wyd. 2, Zakład Narodowy im. Ossolińskich, Wrocław 2007.

Serczyk W. A., Na płonacej Ukrainie. Dzieje Kozaczyzny 1648-1651, Warszawa 1998. 


\title{
Jarosław Poliszczuk
}

Adam Mickiewicz University in Poznań (Poland)

ORCID: 0000-0001-9081-7900.

\section{Graniczne kształty ukraińskiego dramatu. Natalia Maliutina, Ukraińska dramaturgia końca XIX i poczq̨tku XX wieku. Wydawnictwo Adam Marszałek, Toruń 2020, 271 s.}

\section{Border shapes of Ukrainian drama. Natalia Maliutina, Ukraińska dramaturgia końca XIX i poczq̨tku XX wieku. Wydawnictwo Adam Marszałek, Toruń 2020,} 271 s.

\begin{abstract}
:
The review analyses the new book of professor Natalia Maliutina Ukrainian Drama of the End of XIX and Beginning of XX Centuries (Torun 2020). The discussed book offers a systematic view of the Ukrainian drama. The author is interested in the process of the appearance of the new drama's forms and genres on the borders of mentioned ages at the time when in Ukrainian literature period of modernism was beginning. The main attention in the book is dedicated to literary works of outstanding writers such as Ivan Karpenko-Karyi, Lesia Ukrainka, Volodymyr Vynnychenko, Oleksandr Oles. Therefore, the researcher also appeals to the creativity of less known and even forgotten writers of that time, between them Spyrydon Cherkasenko, Liubov Yanovska, Hnat Khotkevych etc. The monography of Natalia Maliutina evidences the influences of European culture on Ukrainian drama and appeals to the wide comparative problems of Europe of the mentioned period.
\end{abstract}

Keywords: Ukrainian literature, drama, genre, writer, identity, modernism, culture.

Autorki dzieła recenzowanego chyba nie ma potrzeby przedstawiać czytelnikowi. Jest ona profesorem nadzwyczajnym w Instytucie 
Filologii Wschodniosłowiańskiej Uniwersytetu w Białymstoku oraz profesorem zwyczajnym w Odesskim Uniwersytecie imienia I. Mecznikowa. Rusycystka, ukrainistka, komparatystka, która specjalną uwagę skupia na badaniach dramaturgii z okresu XIX-XXI st. Szczególnym zainteresowaniem badawczym prof. Natalii Maliutiny jest identyfikacja kulturowa tekstów dramatycznych, a także ujawnienie $\mathrm{w}$ takich tekstach cech performatywnych, co stanowi charakterystyczną osobliwość literatury współczesnej. Kompetencje badawcze w tym zakresie problematyki zostały udowodnione przez poprzednie publikacje Natalii Maliutiny. Mam na myśli przede wszystkim jej monografie autorskie poświęcone przekształceniom tożsamościowym w twórczości współczesnych dramaturgów rosyjskich - Поэтика высказывания в пвесах одесских драматургов Анны Яблонской и Александра Марданя (Poetyka wypowiedzi w sztukach odesskich dramatopisarzy Anny Jabłońskiej i Aleksandra Mardania, Rzeszów 2016) oraz Проблема культурной (само)идентибикациии героя в новейшей постсоветской драме: переформатировка (Problem kulturowej (auto)identyfikacji bohatera w najnowszym dramacie postsowieckim: przeformatowanie, we współautorstwie z Anną Maroń, Kraków 2019) ${ }^{1}$. Interesującą pozycją wydawniczą nawiązującą do zbadania roli performansu we współczesnej kulturze popularnej jest praca zbiorowa Перформатизация современной русской драмы: славянский контекст (Rzeszów 2019) ${ }^{2}$, zainicjowana i zredagowana przez prof. N. Maliutinę. Ten cały dorobek naukowy (oprócz wspomnianych książek warto wspomnieć tutaj również liczne artykuły ogłaszane w czasopismach naukowych) świadczy, że w osobie autorki mamy do czynienia $\mathrm{z}$ wnikliwym i rzetelnym badaczem nowoczesnego i ponowoczesnego dramatu.

1 Zob.: N. Maliutina, Poetika vyskazyvaniya v piesakh odesskikh dramaturgov Anny Yablonskey i Aleksandra Mardanya, Wydawnictwo Uniwersytetu Rzeszowskiego, Rzeszów 2016; N. Maliutina, A. Maroń, Problema kulturnoy (samo)identifikatsii geroya $v$ noveyshey postsovetskoy drame: pereformatirovka, "Collegium Columbinum", Kraków 2019.

2 Performatrizatsiya sovremennoy russkoy dramy: slavyanskiy kontekst, pod red. N. Maliutiney, Wydawnictwo Uniwersytetu Rzeszowskiego, Rzeszów 2019. 
Publikację nowej książki znanej rusycystki i ukrainistki Natalii Maliutiny wypada ocenić jako zdarzenie o wadze wyjątkowej. Oprócz tego, że monografia w sposób istotny uzupełnia dotychczasową wiedzę z zakresu historii literatury ukraińskiej, jest ona udaną próbą systemowego ujęcia rozwoju dramaturgii w przełomowym dla ukraińskiej kultury okresie, jakim był koniec XIX i początek XX wieku. ${ }^{3}$ Autorka obserwuje ewolucje form dramatycznych - od tradycyjnego dramatu obyczajowego preferującego wątki folklorystyczne, etnograficzne bądź historyczne po nowatorski dramat modernistyczny, którego szczytowe osiągnięcia w literaturze ukraińskiej reprezentuje twórczość Łesi Ukrainki oraz Wołodymyra Wynnyczenki. Jej uwaga badawcza skupia się na procesie transformowania rozmaitych gatunków dramatu pod presją niespokojnego, wręcz zbuntowanego czasu, jakim został w piśmiennictwie i sztuce europejskiej przełom wieków.

Przez wnikliwą analizę tekstów ukraińskich dramatopisarzy badaczka uwypukla zasadniczą różnicę, która zachodzi pomiędzy tradycyjnym ujęciem relacji człowieka i rzeczywistości a jej modernistyczną odmianą. Ta różnica przyczyniła się do kształtowania nowej postawy bohatera, ale również rzutowała na rozwój form i gatunków ówczesnego dramatu, zbliżającego się do światopoglądu człowieka nowoczesnego. Przecież, jak twierdzą teoretycy modernizmu,

[...] myśliciele i pisarze dziewiętnastowieczni postulowali lub przynajmniej próbowali postulować współgranie, wzajemną odpowiedniość oraz substancjalną

${ }^{3}$ Przełom modernistyczny cieszył się wyjątkowym zainteresowaniem badaczy ukraińskich w ostatnich dekadach, gdy - po upadku ZSRR oraz po unieważnieniu cenzury sowieckiej - doszło do niezaangażowanych badań nad literaturą końca XIX i pocz. XX st. W tym okresie zostały ukazane solidne rozprawy badawcze autorstwa S. Pawłyczko, T. Hundorowej, J. Poliszczuka, H. Sywaczenko et al. Zob.: S. Pavlychko, Dyskurs modernizmu v ukrainskiy literaturi, Lybid, Kyiv 1997; T. Hundorova, Proiavlennia Slova. Dyskursiia rannioho ukrainskoho modernizmu, vyd. 2, pereroblene ta dop., Krytyka, Kyiv 2009; Y. Polishchuk, Mifolohichnyi horyzont ukrainskoho modernizmu, Lileia-NV, Ivano-Frankivsk 2002; H. Syvachenko, Prorok ne svoiei vitchyzny. Ekspatrianskyi „metaroman” Volodymyra Vynnychenka: tekst $i$ kontekst, Vydavnychyi dim „Alternatyvy”, Kyiv 2003. 
jedność struktury logicznej świata materialnego, struktury ludzkiego logosu oraz [...] współgranie między tym, co Fokkema i Ibsch nazywają „światem pozorów i wyższym światem absolutnego Piękna i Prawdy”. Moderniści, przeciwnie, byli dotknięci $\mathrm{w}$ mniejszym lub większym stopniu poczuciem wzajemnej dyslokacji sfer materialnej, ludzkiej i metafizycznej. (...) Owo poczucie radykalnego wyobcowania manifestuje się szczególnie w modernistycznym potraktowaniu czterech pytań: o status rozumu, o status języka, o naturę historii oraz o status kultury Zachodu. ${ }^{4}$

Autorka książki ujmuje badany okres jako sytuację przejściową pomiędzy tendencją pozytywistyczną dominującą $\mathrm{w}$ piśmiennictwie II połowy XIX stulecia a nasilającym się ruchem modernistycznym, którego wpływy nie były przecież odbierane bez dyskusji w ówczesnym, mocno skolonizowanym społeczeństwie ukraińskim. Paradoksalną cechą tamtego okresu jest to, że powstanie na przełomie wieków nowej świadomości artystycznej młoda generacja twórców zawdzięczała nie tylko wpływom kultury Zachodu, lecz również starym narodnickim formacjom zorientowanym na wzorce kultury europejskiej. Ci starsi pisarze potrafili połączyć hasła tożsamości narodowej z ideami wolności, równości, demokracji. Mimo wszystko na przełomie wieków napięcia kulturowe były odczuwalne bardzo ostro: są to napięcia pomiędzy generacjami, światopoglądami, strategiami estetycznymi etc. Potrzeba konsolidacji na gruncie kultury narodowej aktualizowała wspólne zasady wielu pisarzy, natomiast w ich środowisku ciągle „ścierały się tendencje przeciwstawne: radykalizm estetyczny rodem z Zachodu walczył z pragnieniem zachowania wszystkiego, co przypomina o narodowej tożsamości" ${ }^{5}$.

W ostrej debacie o kondycję literatury ukraińskiej i jej aktualnych drogach rozwojowych wystąpiły w pierwszych latach XX st. najwybitniejsi autorzy - Iwan Franko, Łesia Ukrainka, Mychajło Kociubyński, Olga Kobylańska, Mykoła Woronyj etc. Wspomniana debata dotyczyła głównie twórczości prozatorskiej i poetyckiej. Być może, w odniesieniu do dramaturgii wytyczone przez jej uczestników

${ }^{4}$ R. Sheppard, Problematyka modernizmu europejskiego [w:] Odkrywanie modernizmu, pod red. R. Nycza, Wydawnictwo Universitas, Kraków 1998, s. 112-113.

${ }^{5}$ A. Korniejenko, Ukraiński modernizm, Wydawnictwo Universitas, Kraków 1998, s. 96. 
argumenty nie były tak ostre, jak te stosowane wobec innych gatunków literackich. Niemniej jednak początek XX wieku obfituje, jak dowodzi autorka książki, w ciekawe poszukiwania nowych chwytów poetykalnych w zakresie twórczości dramatycznej. W utworach młodych pisarzy Wołodymyra Wynnyczenki, Ołeksandra Ołesia, Spyrydona Czerkasenki, Hnata Chotkewicza kształtuje się nowa forma, która z czasem zostaje uznana jako narodowy odpowiednik zachodnioeuropejskiego dramatu symbolicznego („nowego dramatu”). Dobrym tłem dla prężnego rozwoju dramaturgii jest także rozkwit życia teatralnego na Ukrainie Naddnieprzańskiej, zwłaszcza po rewolucji 1905 roku, kiedy powstają liczne trupy teatralne z powodzeniem występujące na terenie całej Ukrainy.

Książka o ukraińskiej dramaturgii z przełomu XIX-XX wieku wypełnia poważną lukę badawczą ukazując rozwój dramatu w jego ciągłości procesualnej. Ważną cechą rozprawy naukowej Natalii Maliutiny jest właśnie szerokie spojrzenie na badane zjawisko pozwalające na zarysowanie złożonego procesu kreowania nowych gatunków i podgatunków w ówczesnej twórczości dramatycznej. Oczywiście, głównymi bohaterami prezentowanej monografii są Iwan Karpenko-Kary, Łesia Ukrainka, Wołodymyr Wynnyczenko, czyli pisarze, których zasługi dla rozwoju teatru ukraińskiego są dobrze znane i w żadnej mierze niekwestionowane. Poza tym badaczka dokładnie wyeksponowała również utwory autorów mniej znanych, lecz zasługujących na uwagę w kontekście omawianych zmian modernizacyjnych zachodzących w literaturze ukraińskiej na przełomie wieków.

Rozważania Natalii Maliutiny o dramaturgii ukraińskiej są o tyle istotne, o ile twórczość dramatyczna w tradycyjnym ujęciu była odbierana jako dopełnienie do dorobku prozatorskiego, któremu od XIX wieku przypisywano wagę nadrzędną. Tak więc w starych skryptach $\mathrm{z}$ historii literatury ukraińskiej (np. autorstwa prof. Bohdana Lepkiego ${ }^{6} \mathrm{z}$ okresu międzywojennego) rola dramaturgii i teatru była określona fragmentarycznie. Nie są wolne od podobnego

${ }^{6}$ B. Łepki, Zarys literatury ukraińskiej: podręcznik informacyjny, Warszawa Kraków 1930. 
fragmentaryzmu także niedawno wydane w Polsce opracowania $\mathrm{z}$ tego zakresu wiedzy: omawiając twórczość pisarzy XIX wieku badacze skupiają główną uwagę na twórczości prozaików, zwłaszcza na powieściach Iwana Neczuja-Łewyckiego, Panasa Myrnego, Iwana Franki, natomiast dramaturgia zostaje siłą rzeczy zepchnięta na margines. Taka konstelacja wiedzy o rozwoju piśmiennictwa odpowiada pewnym zasadom ujmowania literackości pod względem jej zapotrzebowania społecznego, choć nie jest do końca słuszna. Brakuje jej precyzji, wobec czego charakterystyka dramaturgii zaproponowana przez Natalię Maliutinę, wydaje się istotnym elementem wzbogacającym systemową wiedzę o ewolucji literackiej, zwłaszcza pod względem gatunkowym.

Autorka książki przekonująco pokazuje na licznych przykładach - zarówno tych znanych w historii literatury ukraińskiej, jak i na nowo odkrytych - jak ważną dziedziną twórczości literackiej była we wspomnianym czasie dramaturgia absorbująca nowe idee oraz lansująca nowe prądy artystyczne. W ten sposób dramatopisarze niespokojnej epoki bezpośrednio przyczynili się do rychłej modernizacji całej kultury narodowej Ukraińców zbliżając ją z kulturą innych krajów europejskich. Zasługi Łesi Ukrainki, Wołodymyra Wynnyczenki, Ołeksandra Ołesia, tzn. pisarzy, którzy wytyczyły nowe drogi $\mathrm{w}$ rozwoju dramaturgii i teatru ukraińskiego na początku nowego stulecia, - w tym zakresie trudno przecenić. Ale także nie należy lekceważyć spuścizny twórczej autorów mniej znanych, pozostających w cieniu wielkich autorytetów, jak słusznie mniema autorka książki Ukraińska dramaturgia końca XIX i poczatcu XX wieku. Stąd wynika opcja skrupulatnego badania dorobku literackiego Hnata Chotkiewicza, Borysa Hrinczenki, Lubowi Janowskiej, Spyrydona Czerkasenki, Adriana Kaszczenki, Nadiji Kybalczicz etc. Warto docenić, że Natalia Maliutina nie tylko poddaje rozważaniu utwory znane i wysoko cenione, ale - wykazując rzetelność i dokładność zaawansowanego badacza - omawia i interpretuje dramaty oraz szkice zapomniane, wydobyte $\mathrm{z}$ archiwów i starych czasopism: $\mathrm{w}$ jej mniemaniu służą bowiem dowodem różnorodności artystycznej w dorobku ukraińskich dramatopisarzy omawianego okresu. 
Całościowa treść książki została ułożona w sposób logiczny i konsekwentny oraz ujęta w sześciu rozdziałach. Za dobry przyczynek do poznania ukraińskiej dramaturgii warto uznać przedmowę do monografii przygotowaną przez jej redaktorów naukowych: Bogusława Bakułę i Agnieszkę Matusiak. Autorzy przedmowy przybliżają czytelnikowi polskiemu przedmiot rozprawy monograficznej - zarówno z punktu widzenia historycznego, traktując o trudnych warunkach i osobliwościach rozwoju piśmiennictwa ukraińskiego w XIX i na pocz. XX wieku, jak i w ujęciu komparatystycznym apelując do kontekstu przełomu modernistycznego w kulturach narodowych Europy Zachodniej i Środkowo-Wschodniej. Wypada zgodzić się z sugestią, iż teksty dramatyczne Łesi Ukrainki czy Wołodymyra Wynnyczenki całkiem dobrze nadają się do porównania $z$ nowatorskim dramatem Henrika Ibsena, Stanisława Wyspiańskiego, Maurice'a Maeterlincka oraz innych znakomitych pisarzy europejskich. Przedmowa jest nie tylko udanym zaproszeniem czytelnika do lektury książki Natalii Maliutiny, ale również wstępnym rozeznaniem w zakresie badań nad dramaturgią ukraińską, która jak dotąd przeważnie była niedoceniana przez historyków literatury.

W rozdziale pierwszym zarysowany zostaje rozwój ukraińskiej dramaturgii omawianej epoki, przy czym szczególna uwaga poświęcona zostaje nieustannemu poszukiwaniu przez pisarzy nowych kształtów literackości w obliczu radykalnych przemian zachodzących w kulturze europejskiej u progu modernizmu. Chodziło o przekształcenie samej istoty akcji oraz konfliktu dramatycznego: zamiast skupienia się na akcji zewnętrznej i wyeksponowania konfliktu widocznego pisarze nowej generacji próbują zanurzyć się w skomplikowany i sprzeczny świat wewnętrzny bohatera, $w$ tym także obserwują jego dylematy moralne, wahania i wątpienia spowodowane doświadczeniami życiowymi i bogatym światem wyobraźni ${ }^{7}$. W tej części książki zostaje ujawniona specyficzna sytuacja teatru ukraińskiego, który w znacznym stopniu zachował tradycję romantyczną, kojarzoną

7 Zob.: R. Sheppard, Problematyka modernizmu europejskiego [w:] Odkrywanie modernizmu..., s. 112. 
z pierwiastkiem narodowym - ludowym językiem, folklorem, obyczajowością. Mówimy przecież o okresie uległości kolonialnej, gdy kultura ukraińska przeżywała mocną presję cenzuralną ze strony władz Imperium Rosyjskiego. W tych warunkach historycznych zachodnioeuropejskie hasła modernizacji sztuki były odbierane w świecie słowiańskim (w tym ukraińskim) niejednoznacznie, ponieważ kultura narodowa była obarczona zobowiązaniami wynikającymi z braku niepodległości narodowej.

W drugim rozdziale badaczka prezentuje twórczość dramatopisarską Iwana Karpenki-Karego, najwybitniejszego przedstawiciela teatru ukraińskiego na przełomie wieków - zarówno autora sztuk, jak i reżysera oraz aktora, realizującego najbardziej głośne podówczas projekty teatralne. Autorka przedstawia postać tego zasłużonego twórcy we właściwej ewolucji jego talentu i wyjaśnia, dlaczego w ostatnich utworach mistrza widoczne są dosyć mocne wpływy nowych tendencji artystycznych. O zachodzących w dramatopisarstwie zmianach świadczy autonomizacja bohatera, wprowadzenie akcentów ironicznych, psychologiczne napięcie akcji etc. - takie cechy N. Maliutina notuje w dramatach Iwana Karpenki-Karego z ostatnich lat jego życia.

Dobrze rozbudowanym wydaje się rozdział trzeci monografii Natalii Maliutiny zatytułowany Zjawiska przejściowe „nowego dramatu” ukraińskiego końca XIX i początku XX wieku. W tej części rozprawy znajdują miejsce najważniejsze wytyczne unowocześnienia ukraińskiego dramatopisarstwa omawianego okresu. Badaczka omawia wpływy sztuki symbolistycznej, zauważa osobliwy psychologizm „nowego dramatu”, śledzi zmiany w postrzeganiu bohatera oraz próby zweryfikowania w duchu czasu dramatu obyczajowego. Przy okazji apeluje również do kontekstów literacko-kulturowych rosyjskich, polskich czy zachodnioeuropejskich. Tematy związane z losem zaangażowanej patriotycznie inteligencji, upadkiem „szlacheckich gniazd" bądź kryzysem tradycyjnej cywilizacji wiejskiej pod koniec XIX st. przecież były popularne w wielu literaturach narodowych. Intrygującym wątkiem dla rozważań jest również symbolizacja obrazowości, uprzedmiotowienie (bądź odwrotnie, 
odprzedmiotowienie) sensów ukrytych w słowach, inspirowanie gier słownych, dostosowanie środków retorycznych do swoistej mody na subtelność obowiązującej w czasie narodzin modernizmu.

Kolejne trzy rozdziały poświęcone zostają wybitnym twórcom „nowego dramatu”, przy czym N. Maliutina dobiera właściwe interpretacyjne klucze do charakterystyki każdej z prezentowanych postaci. Przez to twórczość dramatopisarska Łesi Ukrainki jest ujęta jako „dramaturgia słowa w teatrze poetyckim” - w ten oto sposób podkreślono nowatortstwo poetki w podejściu do zrealizowania tematów powszechnych. Omawiając poematy dramatyczne Ołeksandra Ołesia badaczka podkreśla symbolistyczne podłoże ich obrazowości. Z kolei w postawie twórczej Wołodymyra Wynnyczenki upatruje rzadko spotykaną oryginalność i paradoksalność myślenia, zaprezentowaną w sztukach eksperymentalnych epatujących ówczesną publiczność i drażniących krytyków. ${ }^{8}$ Mimo wszystko to właśnie dramaty Wynnyczenki należy uznać za zjawiska nowatorskie w wielu znaczeniach, zrywały one bowiem z tradycyjną moralnością w okresie nasilających się nastrojów rewolucyjnych i anarchistycznych. Każdy z rozdziałów omawianej monografii Natalii Maliutiny zamyka zwięzłe (z wypunktowanymi zdaniami) podsumowanie. Szkoda, że zabrakło zakończenia reasumującego treść całej rozprawy, choć brak ten częściowo zrekompensowany przez wspomniane nota bene zamieszczone w poszczególnych rozdziałach.

Cennym aneksem są w monografii Natalii Maliutiny Noty biograficzne mało znanych ukrainskich dramatopisarzy. Czytelnik znajdzie tutaj nazwiska wielu zapomnianych autorów, o których rzadko traktują ukraińskie źródła encyklopedyczne. Zamyka całość bibliografia rozprawy ułożona według zasad wydawnictwa naukowego: prezentowane $\mathrm{w}$ niej najważniejsze pozycje $\mathrm{w}$ języku ukraińskim, a także w innych językach.

Lektura monografii autorskiej Natalii Maliutiny Ukraińska dramaturgia końca XIX i początku XX wieku świadczy o tym, że mamy do czynienia z przemyślanym, dobrze ułożonym tekstem naukowym. Bez

${ }^{8}$ Zob.: H. Syvachenko, Ibidem. 
wątpienia o wartości wydania decyduje fakt redakcji naukowej dokonanego przez prof. dr hab. Bogusława Bakuły z Uniwersytetu im. Adama Mikiewicza w Poznaniu oraz prof. dr hab. Agnieszkę Matusiak z Uniwersytetu Wrocławskiego. Książka wyróżnia się na tle innych znanych mi współczesnych pozycji wydawniczych z tego obszaru problematyki badawczej. Mam nadzieję, że będzie z entuzjazmem potraktowana przez czytelnika, zwłaszcza przyda się młodym badaczom ukrainistom, jak również będzie korzystna dla badań o charakterze komparatystycznym, ponieważ odkrywa wiele inspirujących wątków obecnych $\mathrm{w}$ różnych literaturach słowiańskich $\mathrm{z}$ okresu przełomu modernistycznego.

Natalia Maliutina dokładnie wyjaśnia okoliczności historyczne życia literackiego omawianej epoki, ale również z sukcesem prezentuje wybitne postacie i dzieła literatury ukraińskiej, obserwuje ich ścisły związek z ówczesną kulturą europejską. Autorka książki udowadnia, że dramaturgia ukraińska całkiem dobrze wpisuje się w konteksty teatru europejskiego przełomu stuleci, reaguje w sposób adekwatny na eksperymenty ideowo-artystyczne spowodowane przez utwory Henrika Ibsena, Maurice'a Maeterlincka, Gerharta Hauptmanna, Richarda Wagnera. W takim kształcie ukraiński dramat oraz życie teatralne z czasów zwrotu modernistycznego może zainteresować nie tylko badaczy historii i kultury Ukrainy, ale szerszy krąg czytelników zainspirowanych różnorodnością europejskiego modernizmu.

Warto nadmienić, że czytelnik polski stosunkowo słabo obeznany z literaturą bliskich sąsiadów ze Wschodu, mimo wielu podobieństw, które zbliżają piśmiennictwo ukraińskie z polskim, zwłaszcza w okresie trwania pod presją Imperium Rosyjskiego w XIX i na pocz. $\mathrm{XX}$ wieku. Tłumaczenia $\mathrm{z}$ ukraińskiego $\mathrm{w}$ lata poprzednie były wykonywane raczej sporadycznie, a ich znaczenie nieporównywane ze znaczeniem przekładów z rosyjskiego bądź czeskiego. Dopiero ostatnio ta sytuacja ulega pewnej poprawie, lecz dotyczy to głównie ukraińskiej literatury współczesnej, wtedy jak wartościowe dzieła pochodzące z XIX czy pocz. XX wieku zostają w kraju nadal nieznane i nie rozpoznawalne. Podobno jest $\mathrm{z}$ opracowaniami naukowymi: rozprawy z zakresu historii literatury i kultury ukraińskiej rzadko są 
publikowane w Polsce. Wobec tego świeżo opublikowana monografia Natalii Maliutiny wydaje się całkiem aktualną pozycją wydawniczą.

\section{References}

Hundorova T., Proiavlennia Slova. Dyskursiia rannioho ukrainskoho modernizmu, vyd. 2, pereroblene ta dop., Krytyka, Kyiv 2009.

Korniejenko A., Ukraiński modernizm. Próba periodyzacji procesu historycznoliterackiego, Wydawnictwo Universitas, Kraków 1998.

Łepki B., Zarys literatury ukraińskiej: podręcznik informacyjny, Warszawa - Kraków 1930.

Maliutina N., Poetika vyskazyvaniya v piesakh odessikh dramatudgov Anny Yablonskey i Alexandra Mardania, Wydawnictwo Uniwersytetu Rzeszowskiego, Rzeszów 2016.

Maliutina N., Maroń A. Problema kulturnoy (samo)identifikatsii geroya $v$ noveyshey postsovetskoy drame: pereformatirovka, „Collegium Columbinum”, Kraków 2019.

Maliutina N., Ukraińska dramaturgia końca XIX i początku XX wieku, red. naukowa B. Bakuła, A. Matusiak, Wydawnictwo Adam Marszałek, Toruń 2020.

Pavlychko S., Dyskurs modernizmu v ukrainskii literaturi, Lybid, Kyiv 1997.

Performatrizatsiya sovremennoy russkoy dramy: slavyanskiy kontekst, pod red. N. Maliutiney, Wydawnictwo Uniwersytetu Rzeszowskiego, Rzeszów 2019).

Polishchuk Y., Mifolohichnyi horyzont ukrainskoho modernizmu, Lileia-NV, Ivano-Frankivsk; 2002.

Syvachenko H., Prorok ne svoiei vitchyzny. Ekspatrianskyi "metaroman" Volodymyra Vynnychenka: tekst i kontekst, Vydavnychyi dim „Alternatyvy”, Kyiv 2003.

Sheppard R., Problematyka modernizmu europejskiego [w:] Odkrywanie moderni$z m u$, pod red. R. Nycza, Wydawnictwo Universitas, Kraków 1998, s. 71-140. 
VII. Varia 


\title{
Ihor Stambol
}

Borys Grinchenko Kyiv University (Ukraine)

ORCID: 0000-0002-3099-3862

\section{Цвинтар Ольшани у Празі як місце пам'яті українців}

\section{Olshany Cemetery in Prague as a place of memory of Ukrainians}

\begin{abstract}
:
The article clarifies the role of the Olshany cemetery in Prague as a location for the memory of Ukrainians and about Ukrainians. Olshany is one of the largest necropolises of prominent Ukrainians outside Ukraine. Most Ukrainians buried here became emigrants as a result of the defeat of the Ukrainian National Revolution of 1917-1921. The purpose of this article is to demonstrate the perception of this necropolis among Ukrainians, to show some aspects of mentions of Olshany in the Ukrainian information space and to find out its possible role as a place of memory. The topic of Olshany became more active in the Ukrainian media in 2017 due to the threat of losing the grave of one of the most prominent Ukrainian poets of the early twentieth century - Oleksandr Oles (Kandyba) and his wife. The periodicity of attention to Olshany is explained by the interest of Ukrainians in the subject of the Ukrainian National Revolution of 1917-1921, which also acquires a greater resonance closer to the memorable dates. Members of the Ukrainian governments buried in the cemetery, including Fedor Shvets, Stepan Siropolko, Volodymyr Leontovych, Sofia Rusova, Hryhoriy Sydorenko, Apollinarii Marshynsky, as well as scientists and artists Spiridon Cherkasenko, Mykola Andrusov, Yevhen Ivanenko and others, together with the military UGA, are very important part of the memory of Ukrainian post-revolutionary emigration, and involve people in understanding their destinies through the fields in which they were engaged before, during and after the Revolution. That is why Olshany already acts as a place of memory for Ukrainian historians, teachers, diplomats, etc. But given the professional diversity of the people buried there and the significant legacy they have left behind, this place has greater potential. And new generations of Ukrainians who work or study in the Czech Republic now can contribute even more to this.
\end{abstract}


Keywords: Prague, Olshany cemetery, Sofia Rusova, Oleksandr Oles (Kandyba), memory

Цвинтар Ольшани, що знаходиться у столиці Чеської Республіки, внаслідок перебування значної кількості українців у Празі після поразки Національної Революції 1917-1921 років, є одним із найбільш помітних некрополів видатних українців за межами України. Нещодавно в інформаційному просторі України це місце набуло значного звучання, але навряд чи можна сказати, що, крім дослідників та свідомих громадян, воно $є$ відомим місцем. Проте коли українець потрапляє до такого дружнього міста, як Прага, то не може не подивуватися тій ролі, яку вона відіграла у житті біженців з окупованої більшовиками України. Чимало з них знайшли вічний спочинок на цвинтарі Ольшани, тому його можна справедливо називати місцем пам'яті українців. Але яке мнемонічне значення він несе? Що відчуватиме українець або представник іншої нації, який потрапить у це місце? Мета статті - продемонструвати сприйняття цього некрополя серед українців. Завданнями $є$ висвітлення згадок про Ольшани в українському інформаційному просторі та з'ясування його можливої ролі як місця пам'яті.

Варто відзначити, що саме поняття «місце пам'яті» $є$ досить багатозначним ${ }^{1}$. У цьому випадку зводиться до місця, що має значний потенціал осмислення періоду, певного діяча, складної долі емігранта-українця або ж галузі, з якою були пов'язані поховані на Ольшанах. Цвинтарі є одними 3 найдавніших «центрів» пам'яті про людей минулих епох, які дозволяють живим зберігати враження, що померлі не зникли безслідно. Водночас місця поховань видатних представників певного суспільства часто стають місцями паломництва, завдяки чому

${ }^{1}$ S. Nabok, Prostir i pamiat: na perekhrestiakh kontekstiv [w:] „Naukovi zapysky Instytutu politychnykh i etnonatsionalnykh doslidzhen im. I. F. Kurasa NAN Ukrainy", 2017, Vyp. 5-6, s. 244-253. 
навіть розвинувся цілий напрям - «некропольний туризм» 2 . Празький цвинтар Ольшани займає помітне місце у цій галузі для багатьох поколінь та народів, зокрема і для українців.

Стаття в газеті «Україна молода» за 2004 рік висвітлює деякі аспекти створення православного некрополя, зокрема, побудову церкви у «псковсько-новгородському стилі» ${ }^{3}$. Інтернет-сторінка «Радіо свобода» 2009 року вмістила статтю Олени Пеленської про кубанського українця - дослідника Федора Щербину, прах якого донедавна покоївся на цвинтарі Ольшани, але був вивезений росіянами без відома українців. Авторка також звертала увагу на те, що більшість українських некрополів у Чеській Республіці не мають догляду і поступово зникають ${ }^{4}$ В інтернет-виданні «Історична правда», метою якого є популяризація української історії, міститься публікація «Могили наших у Празі. Екскурсія Ольшанським кладовищем», де демонструвалися світлини могил українців з коротким історичним екскурсом 5 .

Найактивніше в українських 3MI тема Ольшан зазвучала 2017 року у зв'язку із загрозою втрати могили одного з найвидатніших українських поетів початку ХХ століття Олександра Олеся (Кандиби) та його дружини. Тоді мешканець Праги, який сплачував оренду за місце на цвинтарі, помер, і попри те що плату було внесено, син орендодавця хотів на місці могили видатного поета поховати вже свого батька. У цьому випадку досить добре спрацювали українське Міністерство закордонних справ та інші урядові інституції, влаштувавши ексгумацію і урочисте перепоховання літератора в Києві на Лук'янівському цвинтарі 6 .

2 O. Buhrii, Nekropolnyi turyzm ta yoho obiekty na Ukraini [w:] „Heohrafiia ta turyzm", 2010, Vyp. 4, s. 52-62.

3 V. Kipiani, Nashi mohyly na Olshanakh [w:] „Ukraina moloda”, [19.05.2004], https://www.umoloda.kiev.ua/number/181/204/6263/

4 O. Pelenska, Nashi - ne nashi mohyly, "Radio Svoboda", [26.02.2009], https:// www.radiosvoboda.org/a/1500042.html

${ }^{5}$ Mohyly nashykh u Prazi. Ekskursiia Olshanskym kladovyshchem [w:] „Istorychna pravda", [21.08.2021], https://www.istpravda.com.ua/artefacts/4d304aa0d0c23/

6 Ekshumatsiia prakhu Oleksandra Olesia. Khronika skandalu [w:] „Istorychna pravda”, [21.08.2021], https://www.istpravda.com.ua/short/2017/01/4/149424/ 
Ці події призвели і до появи значної кількості публіцистичних статей, одна з яких красномовно визначила ставлення українців до своїх співвітчизників, похованих у Празі, як «Національне безпам'ятство» ${ }^{7}$.

Показовими для з'ясування сприйняття сучасними українцями місця поховання післяреволюційних емігрантів до Чехії можуть служити дані «Google-trends», що зберігає запити користувачів найпопулярнішої у світі пошукової системи «Google». Пошукові запити «Ольшанський цвинтар» з України (українською мовою) не були масовими, але є достатніми, аби простежити динаміку. За даними за увесь час - найбільше їх спостерігалося у квітні 2007 року, вдвічі менше було у серпні 2008 року, надалі невелика активність спостерігається у липні 2012, січні 2013, липні 2014 років, січні 2016 року, грудні, березні і вересні 2017 року, вересні-жовтні 2018 року та лютому-березні 2019 років. Одним із пояснень такої періодичності запитів, вочевидь, можна вважати зацікавлення українців тематикою Української Національної Революції 1917-1921 рр., яке також набуває більшого резонансу ближче до пам'ятних дат. Аналіз запитів за п'ять останніх років свідчить про найбільше зацікавлення користувачів Інтернету у січні, серпні та грудні 2017 року, якраз у той рік, коли відбулася ексгумація та перепоховання Олександра Олеся.

Окрім того, трапляться згадки про цвинтар, як важливе місце для українців, і на різноманітних популярних чеських ресурсах. Так, у 2019 році у популяризаційному ролику «Українські місця у Празі», знятому на замовлення Посольства України в Чехії знімальною групою «ОМ Media Production» (режисером і продюсером фільму стала відома у Празі журналістка Оксана Мойсенюк) як одне з таких місць позначено й Ольшани. Наразі Празькі краєзнавчі осередки слідкують за могилами та поряд із похованнями видатних діячів облаштовано інформаційні таблички з QR-кодами для швидкого отримання інформації про похованих

7 A. Chernov, Natsionalne bezpamiatstvo: Olshanskyi tsvyntar bilia Prahy [w:] „Ukrainske slovo”, 2017, Vol. 4 (25-31 sich.), s. 4, (Koly poshanuiemo svoikh) 
Праця Оксани Пеленської «Україна поза Україною» також суттєво доповнює географію української еміграції в Чехії та значення цвинтаря як останнього спочинку для багатьох з них У статті Ольги Зубко відзначено занепад українських некрополів на території Чеської Республіки та перелік видатних українців, зокрема і похованих на Ольшанах ${ }^{9}$. Водночас Ольшани згадуються у науково-інформаційній площині України не лише в контексті поховань українців. Наприклад, у літературознавчих розвідках, зокрема щодо поетики символів чеської письменниці Даніели Годрової, відзначено «а за спиною на знімку Ольшанський цвинтар - один 3 ключових топосів у романах» ${ }^{10}$. Тобто українські дослідники звертають увагу і на рецепцію цього місця серед чехів.

Незважаючи на значне обурення української громадськості справою могили Олександра Олеся та досить вдалі дії збоку українських урядовців, які продемонстрували правильний приклад вирішення ситуації, інші поховання українців за кордоном, схоже, чекає доля могили згаданого поета. Станом на 2020 рік порожня могила видатного поета ще присутня в Ольшанах, але ії̈ значення сприймається вже більше як маркер занепаду діаспорних спільнот та мале зацікавлення в українців до перенесення праху своїх видатних діячів на територію вже незалежної Батьківщини. Наразі можна визначити основні моменти, які характеризують цвинтар як місце пам'яті, що могло 6 стати основою екскурсій та різноманітних пам'ятних програм для студентів-українців та великої кількості українських трудових мігрантів у Чехіі.

${ }^{8}$ O. Pelenska, Ukraina poza Ukrainoiu: Entsyklopedychnyi slovnyk mystetskoho, kulturnoho i hromadskoho zhyttia ukrainskoi emihratsii v mizhvoiennii Chekhoslovachchyni (1919-1939), Praha 2019.

${ }^{9}$ O. Zubko, Zdobutky i vtraty ukrainskoi emihratsiinoi elity: otsinka $v$ chasi (ChSR, 1918 - 1939 rr.) [w:] „Istorychni i politolohichni doslidzhennia”, 2018, № 2, s. 79-90.

${ }^{10}$ Y. Polova, Poetyka symvoliv u romani Daniely Hodrovoi «Teta» [w:] „Komparatyvni doslidzhennia slovianskykh mov i literatur. Pamiati akademika Leonida Bulakhovskoho", 2009, vyp. 10, s. 398-406. 
Насамперед, у контексті пам'яті варто згадати історію Української Революції. Тут похований один 3 членів Директорії Української Народної Республіки - Федір Швець (19091940) - науковець-геолог, політик і дипломат, який долучився до розбудови української вищої освіти, як у вільній Україні, так і в різноманітних еміграційних освітніх інституціях ${ }^{11}$. У контексті українського державотворення однією із найпомітніших сторінок його діяльності став Акт Злуки УНР та ЗУНР 22 січні 1919 року. Адже саме він читав текст цього документа для велелюдного Софійського Майдану в Києві. Проблема Соборності українських земель $є$ перманентною і набуває нових наголосів у контексті окупації територій РФ. Вона завжди лунає з прив'язкою до Акту 1919 року, а отже й до Федора Швеця, похованого на Ольшанах.

Ще однією відомою постаттю, яка знайшла спочинок на цвинтарі Ольшани і пов'язана з багатьма періодами українського націєтворення та педагогіки, є Софія Русова (1856-1940). В юності вона долучилася до діяльності Київської та Харківської Громади, виступала з рефератами на роковинах Т. Шевченка та підтримувала разом з чоловіком Олександром Русовим україномовне книговидавництво. Вона також входила до таємної самостійницької організації «Братерство Тарасівців», за участь у якому навіть була ув'язнена поліцією ${ }^{12}$. Починаючи 3 часів Першої Російської революції, Софія Русова активно працювала на ниві української освіти, публікувала теоретичні праці, проводила лекції, боролася проти російської колоніальної політики в галузі виховання нових поколінь.

У період Української Народної Республіки Софія Русова входить до Центральної Ради і Секретаріату освіти, в якому очолювала

${ }^{11}$ O. Zubko, 2013 rik: 131-i rokovyny $z$ dnia narodzhennia Fedora Petrovycha Shvetsia (1882-1940 rr.) [w:] „Chasopys ukrainskoi istorii”, 2014, vyp. 29, s. 51-58.

12 Більше про тарасівців тут: I. Stambol, Vplyv Ukrainskoi revoliutsii 1917 - 1921 rr. na doli yii natkhnennykiv (na prykladi uchasnykiv "Braterstva Tarasivtsiv») [w:] „Ukrainska biohrafistyka”, 2017, vyp. 15, s. 105-121. 
дошкільний і позашкільний відділи ${ }^{13}$. Її внесок у концепцію національної освіти є визнаним в Україні і значною мірою прописані нею постулати, в тому числі і щодо розвитку творчого мислення дітей, досі використовуються в освіті. Емігрувавши до Чехословацької Республіки, діячка не припинила своїх педагогічних студій і видала десятки теоретичних праць. Окрім того, у Празі вона виступила організатором українського жіночого руху, вписавши таким чином своє ім'я у всі можливі українські дослідження гендерних студій. Тож місце ії поховання є важливою точкою на карті осмислення української педагогіки та жіночого руху.

Також важливою постаттю української педагогіки та науки $€$ Степан Сірополко (1872 - 1959) - педагог, організатор шкільництва та освіти України, міністр освіти в уряді Директорії УНР, бібліограф та історик освіти. Разом із Софією Русовою він активно працював у напрямку становлення української освіти як за часів Революції, так і в еміграції. Його науковий та громадський доробок також важливий у контексті розвитку книжкової та бібліотечної справи. Тому коли дослідники звертаються до теми становлення вітчизняного бібліотекознавства та національної бібліографії, оминути внесок Степана Сірополка неможливо ${ }^{14}$. Трохи у меншій мірі це стосується і розвитку теоретичних та практичних засад української журналістики, хоч науковець активно апелював до появи власне українського типу газет та публіцистики ${ }^{15}$.

Ще один український громадський і політичний діяч, який похований на Ольшанах, Володимир Леонтович (1866-1933) -

${ }_{13}$ Sofiia Rusova - pedahoh, derzhavnyi diiach, prosvitytel: do 155-richchia vid dnia narodzhennia: biobibliohr. pokazhch., uporiad. A. M. Dorkenu, T. V. Loha, avt. vstup. st. Y. Kovalenko, Kyiv 2010.

${ }^{14}$ T. Kivshar, Stanovlennia Stepana Siropolka yak bibliotekoznavtsia [w:] „Ukrainska biohrafistyka", 2010, vyp. 6, s. 103-124.

${ }_{15}$ P. Brytskyj, Stepan Siropolko - vydatnyi pedahoh, bibliotekoznavets ta istoryk osvity Ukrainy [w:] "Naukovi pratsi Kamianets-Podilskoho natsionalnoho universytetu imeni Ivana Ohiienka", Ser. : Bibliotekoznavstvo. Knyhoznavstvo, 2013, vyp. 3 , s. $18-26$. 
міністр Української Держави Скоропадського. Постать прямо пов'язана з видавництвом київських газет «Громадська думка» і першої щоденної газети Наддніпрянщини «Рада». Від його меценатських та дипломатичних зусиль залежала значна частина наукових проєктів Михайла Грушевського, громадських ініціатив Євгена Чикаленка та багато інших науковців та письменників ${ }^{16}$. Він і сам є автором багатьох художніх творів. Водночас його погляди і знання стали основою земельного закону - такого проблемного і для сучасної України питання - який дослідники називають одним із найдемократичніших на той час ${ }^{17}$. Окрім того, Володимир Леонтович долучався до створення української юридичної термінології - 1919 року світ побачив «Московськоукраїнський правничий словничок», який охоплює 4396 слів. Могила цього діяча - це місце пам'яті про українця-мецената, який перебував у епіцентрі національного творчого і видавничого руху, а також був успішним підприємцем та благодійником.

Григорій Сидоренко (1874-1924) - підписаний на цвинтарі як «міністр посол УНР»- уродженець Херсонщини, інженер шляхів, міністр Пошти і телеграфу УНР. Як міністр відзначався українізаційною політикою у своєму відомстві. Серед його досягнень як дипломата було керівництво українською делегацією на Паризькій мирній конференції. Щоправда, перемовини не виявилися тоді вдалими, мемуаристи згадують, що Григорій Сидоренко навіть гримнув кулаком по столу під час перемовин з Жоржем Клемансо, коли той пропонував зменшити території УНР 18 . Працював послом у Відні, а в часи

${ }^{16}$ I. Hyrych, Volodymyr Leontovych v ukrainskomu hromadsko-politychnomu zhytti [w:] "Ukrainskyi arkheohrafichnyi shchorichnyk", 2012, vyp. 16-17, s. 268-299. 17 Ukrainskyi podvyzhnyk i literator: do 150-richchia vid dnia narodzhennia Volodymyra Mykolaiovycha Leontovycha: biobibliohrafichnyi pokazhchyk, uporiad. N. I. Tarasova, O. V. Leontovych, NPU imeni M. P. Drahomanova, Kyiv 2016, s. 9-14.

${ }^{18}$ Y. Kostyk, Dyplomatychna diialnist hrafa Mykhaila Tyshkevycha (Za materialamy periodychnykh vydan) [w:] „Zbirnyk prats Naukovo-doslidnoho instytutu presoznavstva”, 2011, vyp. 1, s. 130-141. 
еміграції долучився до бібліотечної справи - керував бібліотекою Української господарської академії в Подєбрадах.

Також уродженець Херсонщини - Аполінарій Маршинський (1865-1929) - підписаний на надмогильному камені як «в.о. міністра фінансів УНР», працював у багатьох фінансових установах, водночас долучаючись до справ «Старої громади». Незважаючи на свій фах, в еміграції викладав українську літературу та займався перекладами.

Простір Ольшанського цвитаря опосередковано пов'язує сьогодення зі знаковим для українського історіописання твором «Історією України-Русі» Миколи Аркаса. Там поховано дружину видатного історика та композитора Ольгу (1857-1936), в дівоцтві Шишкіну. За життя чоловіка вона активно сприяла його творчим пошукам, долучалася до збору етнографічних матеріалів, а після смерті Миколи Аркаса, долаючи фінансову скруту, 1912 року організувала друге видання однієї з найпопулярніших праць 3 історії України. Перед еміграцією вона передала велику кількість документів до архівів та бібліотек, що зараз є основою для багатьох досліджень з історії української інтелігенції рубежу XIX-XX століть ${ }^{19}$. Родина Аркасів, окрім їхнього творчого внеску в українську культуру, також є знаковим явищем Півдня України: попри грецьке походження та ласку з боку російської влади, міцно трималися саме проукраїнських позицій.

Ще одним уродженцем півдня України, що похований на Ольшанах, $є$ відомий письменник і драматург Спиридон Черкасенко (1876-1940). У дореволюційний період він відзначився як педагог та журналіст, а в період Революції став одним із основних укладачів українських підручників ${ }^{20}$. В еміграції, спочатку в Ужгороді, видавав періодику для молоді, а далі осів неподалік Праги. Художні тексти Спиридона Черкасенка

${ }^{19}$ V. Shkvarets, Mykola Mykolaiovych Arkas: Zhyttia. Tvorchist. Diialnist, Mykolaiv-Odesa, 2002.

${ }^{20}$ Spyrydon Cherkasenko: postat u vyri istorii: rekomendatsiinyi spysok literatury, uklad. L. Shevtsova, Mykolaiv 2016. 
також пройняті темою дитинства та виховання молодого покоління ${ }^{21}$.

Академік Микола Андрусов (1861-19924) - одесит, випускник місцевого університету - відомий вчений-геолог, професор Юр'ївського (Тарту) та Київського університетів. Його праці з геології, зокрема Чорного моря, досі $є$ актуальними для спеціалістів. Він є першовідкривачем багатьох видів та автором багатьох гіпотез стосовно розвитку Чорного моря, чому посприяла перша глибоководна експедиція в морі, організована ним $^{22}$. Незважаючи на російське підданство Миколи Андрусова, його науковий доробок важливий для українців і місце поховання має значення в контексті сприйняття його ідей та осмислення наукового шляху.

Поряд зі згаданими вище, на Ольшанах поховані й інші українські інтелектуали, зокрема Євген Іваненко (1883-1941) професор математики, Українського Високого Педагогічного Інституту в Празі, автор шкільних підручників з математики; Кузьма Безкровний (1876-1937) - уродженець Кубані, один із ініціаторів створення Кубанської Народної Республіки і проголошення ïi конституції, а також прихильник Соборності України, лектор Української господарської Академії; професор Марія Славінська (1879-1958) та «In Memoriam» професор Максим Славінський (1868-1945); Антін Хмарук та «In Memoriam» дипломату та члену Центральної Ради УНР Миколі Галагану, якого совєтські каральні органи вивезли з Чехії після Другої світової і вбили; член Ради республіки УНР, доктор історії Яків Огородник (1894-1930).

Помітними є і декілька могил українських військових: Осипа Баб’юка (1894-1950) - хорунжого Української Галицької Армії

${ }^{21}$ I. Kotiash, Avtobiohrafichni elementy khudozhnikh tvoriv Spyrydona Cherkasenka [w:] „Literatura. Dity. Chas: Visnyk Tsentru doslidzhennia literatury dlia ditei ta yunatstva", vyp. 4, 2013, s. 75-80.

22 N. Shatalov, Akademik Mykola Ivanovych Andrusov - zasnovnyk morskyi heolohii i okeanolohii. Do 155-richchia vid dnia narodzhennia [w:] „Heolohiia i korysni kopalyny Svitovoho okeanu”, 2016, № 12 (1), s. 81-92. 
та «In Memoriam» сотнику УГА, професору Івану Баб’юку та Николі Баб’юку, який загинув у бою 1919 року. Крім того, там поховано ще одного хорунжого УГА - Антіна Будницького. Варто зауважити, що в іншому крилі цвинтаря $є$ окреме поховання советських вояків, що брали участь у боях за Прагу, серед яких, вочевидь, було чимало етнічних українців. Проте їхні могили несуть переважно просовєтські або і проросійське символічне навантаження, зокрема і через характер розміщення пам'ятників та символіку тоталітарної імперії.

Напевно, неможливо описати усі могили похованих на цвинтарі Ольшани українців, адже вони розміщені по сусідству з російськими діячами «білого руху», деякі вже зникли, втратили надписи або й хрести, інші були перенесені. Навколо православної церкви багато могил без табличок, тож, напевно, чимало «нашого цвіту» вже і не відшукати. Часто серед авторів, що описують це місце, виникає плутанина стосовно поховання того чи іншого діяча на цьому цвинтарі, з причини його проживання у Празі. Зокрема у багатьох біографічних нарисах про ще одного міністра УНР - Сергія Шелухина - згадується, що його було поховано на Ольшанах, але відомостей про могилу віднайти не вдалося зовсім.

Узагальнюючи, варто відзначити, що Ольшанський цвинтар, переважно пов'язаний з українськими інтелектуалами та провідниками державного будівництва. Для пересічного українця, більшість зі згаданих постатей $є$ маловідомими, або про них знають фрагментарно. Тому Ольшани вже зараз виступають як місце пам'яті для українських істориків, педагогів, дипломатів тощо. Але з огляду на професійне різноманіття похованих там людей і значний спадок, який вони залишили після себе, це місце має дуже великий потенціал. I ще більше цьому можуть посприяти нові покоління українців, які працюють або навчаються у Чеській Республіці. Загалом це місце наштовхує на думку про долю інтелігенції народу, який не здатен розпізнати правду і кривду та звик сприймати чужинецькі «прості рішення» для складних питань: від засвоєння популістських більшовицьких 
гасел, до тих, надмірно пацифістських та малоросійських, які задурманюють сучасні покоління українців. Символічна могила «від матері України - тї вірним синам» за такого погляду набуває набагато ширшого значення.

\section{References}

Brytskyi P., Stepan Siropolko - vydatnyi pedahoh, bibliotekoznavets ta istoryk osvity Ukrainy [w:] "Naukovi pratsi Kamianets-Podilskoho natsionalnoho universytetu imeni Ivana Ohiienka”, Ser. : Bibliotekoznavstvo. Knyhoznavstvo, 2013, vyp. 3, s. 18-26.

Buhrii O., Nekropolnyi turyzm ta yoho obiekty na Ukraini [w:] „Heohrafiia ta turyzm", 2010, vyp. 4, s. 52-62.

Chernov A., Natsionalne bezpamiatstvo: Olshanskyi tsvyntar bilia Prahy [w:] „Ukrainske slovo”, 2017, vol. 4 (25-31 sich.), s. 4, (Koly poshanuiemo svoikh)

Ekshumatsiia prakhu Oleksandra Olesia. Khronika skandalu [w:] „Istorychna pravda", [21.08.2021], https://www.istpravda.com.ua/short/2017/01/4/149424/ Hyrych I., Volodymyr Leontovych v ukrainskomu hromadsko-politychnomu zhytti [w:] "Ukrainskyi arkheohrafichnyi shchorichnyk", 2012, vyp. 16-17, s. 268-299. Kipiani V., Nashi mohyly na Olshanakh [w:] „Ukraina moloda”, [19.05.2004], https://www.umoloda.kiev.ua/number/181/204/6263/

Kivshar T., Stanovlennia Stepana Siropolka yak bibliotekoznavtsia [w:] „Ukrainska biohrafistyka”, 2010, vyp. 6, s. 103-124.

Kostyk Y., Dyplomatychna diialnist hrafa Mykhaila Tyshkevycha (Za materialamy periodychnykh vydan) [w:] „Zbirnyk prats Naukovo-doslidnoho instytutu presoznavstva”, 2011, vyp. 1, s. 130-141.

Kotiash I., Avtobiohrafichni elementy khudozhnikh tvoriv Spyrydona Cherkasenka [w:] „Literatura. Dity. Chas: Visnyk Tsentru doslidzhennia literatury dlia ditei ta yunatstva", vyp. 4., 2013, s. 75-80.

Mohyly nashykh u Prazi. Ekskursiia Olshanskym kladovyshchem [w:] „Istorychna pravda”, [21.08.2021], https://www.istpravda.com.ua/artefacts/4d304aa0d0c23/

Nabok S. Prostir i pamiat: na perekhrestiakh kontekstiv [w:] „Naukovi zapysky Instytutu politychnykh i etnonatsionalnykh doslidzhen im. I. F. Kurasa NAN Ukrainy", 2017, vyp. 5-6, s. 244-253.

Pelenska O., Nashi - ne nashi mohyly, "Radio Svoboda”, [26.02.2009], https:// www.radiosvoboda.org/a/1500042.html

Pelenska O., Ukraina poza Ukrainoiu: Entsyklopedychnyi slovnyk mystetskoho, kulturnoho i hromadskoho zhyttia ukrainskoi emihratsii v mizhvoiennii Chekhoslovachchyni (1919-1939), Praha 2019. 
Polova Y., Poetyka symvoliv u romani Daniely Hodrovoi «Teta» [w:] „Komparatyvni doslidzhennia slovianskykh mov i literatur. Pamiati akademika Leonida Bulakhovskoho", 2009, vyp. 10, s. 398-406.

Shatalov N., Akademik Mykola Ivanovych Andrusov - zasnovnyk morskyi heolohii i okeanolohii. Do 155-richchia vid dnia narodzhennia [w:] „Heolohiia i korysni kopalyny Svitovoho okeanu", 2016, № 12 (1), s. 81-92

Shkvarets V., Mykola Mykolaiovych Arkas: Zhyttia. Tvorchist. Diialnist, MykolaivOdesa 2002.

Sofiia Rusova - pedahoh, derzhavnyi diiach, prosvitytel: do 155-richchia vid dnia narodzhennia: biobibliohr. pokazhch., uporiad. A. M. Dorkenu, T. V. Loha, avt. vstup. st. Y. Kovalenko, Kyiv 2010.

Spyrydon Cherkasenko: postat u vyri istorii: rekomendatsiinyi spysok literatury, uklad. L. H. Shevtsova, Mykolaiv 2016.

Stambol I., Vplyv Ukrainskoi revoliutsii 1917 - 1921 rr. na doli yii natkhnennykiv (na prykladi uchasnykiv «Braterstva Tarasivtsiv») [w:] „Ukrainska biohrafistyka”, 2017, vyp. 15, s. 105-121.

Ukrainskyi podvyzhnyk i literator: do 150-richchia vid dnia narodzhennia Volodymyra Mykolaiovycha Leontovycha: biobibliohrafichnyi pokazhchyk, uporiad. N. I. Tarasova, O. V. Leontovych, NPU imeni M. P. Drahomanova, Kyiv 2016. Zubko O., 2013 rik: 131-i rokovyny $z$ dnia narodzhennia Fedora Petrovycha Shvetsia (1882-1940 rr.) [w:] „Chasopys ukrainskoi istorii”, 2014, vyp. 29, s. 51-58.

Zubko O., Zdobutky i vtraty ukrainskoi emihratsiinoi elity: otsinka v chasi (ChSR, 1918 - 1939 rr.) [w:] „Istorychni i politolohichni doslidzhennia”, 2018, № 2, s. 79-90. 


\section{Tetiana Kachak}

Vasyl Stefanyk Precarpathian National University (Ukraine)

ORCID: 0000-0002-6863-1736

\section{Дитинство в часи кризи XX-XXI ст. у літературі та культурі Центральної та Східної Європи}

\section{Childhood during the crisis of the XX-XXI centuries in literature and culture of Central and Eastern Europe}

Час і суспільні умови формують образ дитини і дискурс дитинства у соціокультурному вимірі національного і світового буття, генерують актуальний предмет мультидисциплінарних наукових студій. Проблема репрезентації дитинства в часи кризи XX-XXI ст. у літературі та культурі Центральної та Східної Європи стала ключовою темою міжнародної наукової конференції, організованої кафедрою україністики Варшавського університету 28-29 травня 2020 р.

У вітальних зверненнях до учасників завідувач кафедри україністики dr Katarzyna Jakubowska-Krawczyk і декан факультету прикладної лінгвістики Svitłana Romaniuk наголосили на важливості наукових заходів такого формату. У колі фахівців $€$ можливість детально обговорити проблему, дискутувати і формувати різнобічне і в той же час цілісне уявлення про літературні, культурні явища, процеси і феномени. Кафедра україністики започаткувала серію «камерних» конференцій у 2019 році. Тоді науковці «Pracownia Badań nad Ukraińską Tożsamością» зініціювали конференцію «Ukraińskie światy dzieciństwa i młodości» (10.06.2019), а дослідники «Pracownia Dziejów Polsko-Ukraińskich Stosunków Literackich» - «Filozofia bycia i przetrwania (siły witalnej, 
oporu) w ego-dokumenrach pisarzy, malarzy, filmowców ukraińskich (od Orlika do współczesnych)» (9.11.2019).

Онлайн-режим не завадив упродовж двох днів плідно працювати філологам, культурологам і мистецтвознавцям із університетів Польщі, України, Хорватії. Цікаві презентації досліджень, жвава дискусія, виважений полілог розширили погляди науковців на проблему дитинства у літературі й культурі.

Доповіді першої сесії транслювали оригінальні й новаторські інтерпретації світу дитини у творах письменників-класиків. Канд. філол. наук, доц. Богдан Тихолоз (Львівський національний університет імені Івана Франка) проаналізував сенси і модуси метафори дитинства, оприявленої у багатожанровій творчій спадщині Івана Франка. Науковець окреслив широкий спектр варіантів філософського (пере)осмислення цієї метафори: «від автобіографічно-мемуарного его-образу “малого Мирона", через художнє моделювання комплексу сирітства, численні варіації на тему проблематики школи і виховання - до усвідомлення продуктів творчості як власних “духових дітей”, а нереалізованих задумів - як “невроджених дітей”».

Зображення дитинства у ранніх оповіданнях Михайла Коцюбинського у контексті творення канону модерної прози детально розглянув професор Ярослав Поліщук (Uniwersytet Adama Mickiewicza). Канд. філол. наук, доцент Ольга Яблонська (Східноєвропейський національний університет імені Лесі Українки) зосередила увагу на проблемі індивідуальної та національної ідентичності дитини у творчості Модеста Левицького.

Учасники другої конференційної сесії презентувати результати досліджень, предметом яких були автобіографічні спогади письменників про власне дитинство. Проф. Walentyna Sobol (Uniwersytet Warszawski) дала широкий огляд зображення дитинства і дитини в історіях приватного життя, зацікавила аналізом документів, які свідчать про особливості розвитку, навчання і виховання дитини в суспільних умовах минулих епох.

3 цікавою доповіддю «Пам'ять як Дім: світ дитинства у мемуарному дискурсі родини Франків» виступила проф. Наталія 
Тихолоз (Львівський національний університет імені Івана Франка). Дослідниця зіставила спогади про батька дітей Івана Франка і увиразнила уявлення про їхні дитячі роки.

Канд. філол. наук, доц. Оксана Пашко (Національний університет «Києво-Могилянська академія») для аналізу обрала спогади про дитинство Володимира Куліша і спрямувала увагу наукової спільноти на проблеми трагічних доль дітей письменників «розстріляного відродження» у радянський час.

На прикладі аналізу дитячої прози 1930-х років доктор філол. наук, проф. Ольга Харлан (Бердянський державний педагогічний університет) продемонструвала суть експерименту більшовицької влади щодо побудови «нового суспільства» і формування «нової людини». Імпонує позиція дослідниці щодо актуальності певних аспектів тогочасної традиції зображення дитинства і образу дитини. Йдеться, насамперед, про показ дитинства як життєвого етапу, в якому формуються важливі загальногуманістичні цінності (дружби, вірності, відповідальності тощо).

Нові ракурси у дослідженні теми воєнного дитинства у новелістиці Григора Тютюнника завдяки інструментарію постколоніальної методології відкрила проф. Halina Korbicz.

Дитячі страхи і травми - маркери дитинства у часи суспільних криз, голокосту, воєн; лейтмотиви творів для дорослих центральна проблема доповідей і дискусій під час роботи третьої сесії конференції. Канд. філол. наук, доц. Ірина Яковенко (Київський університет імені Бориса Грінченка) грунтовно дослідила топологію дитячого страху та репрезентацію станів афекту FEAR-TERROR в романі Світлани Алексієвич «Останні свідки. Соло для дитячого голосу». Систему дитячого сприйняття жорстокої дійсності з позицій двох однолітків - німецького хлопчика Бруно та єврейського Шмуля в окупованого німцями Кракові проаналізувала у контексті інтерпретації роману Дж. Бойна «Хлопчик у смугастій піжамі» докт. філол. наук, проф. Світлана Ковпік (Криворізький державний педагогічний університет).

Нові ракурси художньої інтерпретації дитинства і процесів дорослішання дитини на тлі епохи, з урахуванням урбаністичних 
топосів і локусів у контексті літературознавчого прочитання роману Ю. Винничука «Танго смерті» розглянула Marta Kaczmarczyk (Katolicki Uniwersytet Lubelski Jana Pawła II). На прикладі сучасної української прози Paulina Olechowska (Uniwersytet Warszawski) порушила проблему актуалізації постпам'яті у досвіді дитини.

Четверту сесію конференції було присвячено обговоренню літератури, адресованої дітям. Докт. наук із соціальних комунікацій, проф. Світлана Кравченко (Східноєвропейський національний університет імені Лесі Українки) запропонувала огляд українського книговидання для дітей, зробила спробу виокремити традиції та нові тренди. Під час обговорення доповіді проф. Галина Корбіч зазначила: «Власне, за великим переліком, що стосується книговидавничої справи, забракло висвітлення тенденцій книговидавничого процесу/процесів та аналітичного занурення в нові тренди». А Ольга Новик вказала на те, що «сучасні тенденції кризового стану книговидавництва в Україні посутньо змінять цифри, наведені Світланою Кравченко, оскільки видавництва для дітей змушені припинити своє існування».

На переоцінці постмодерних європейських цінностей та специфіці зображення дитини в каноні української та німецької літератур для юних читачів зосередила свою доповідь канд. філол. наук, доц. Уляна Баран (Донецький національний університет імені Василя Стуса; Центр дослідження літератури для дітей та юнацтва). Погляди дослідниці щодо функціональних параметрів тексту, його впливу на формування національної та європейської ідентичності дитини-читача викликали жваву дискусію. Ольга Яблонська у коментарях уточнює: «Слушна думка п. Уляни про те, що проблема дитини - на перетині засадничих світоглядних питань суспільства. Однак поняття європейської людини має національні особливості».

«Образ дитини - концептуальна основа сучасної української прози для дітей та юнацтва» - тема доповіді док. філол. наук, проф. Тетяни Качак (Прикарпатський національний університет імені Василя Стефаника). Дослідниця висвітлила основні 
принципи й тенденції творення дитячих образів, проаналізувала найпоширеніші типи дітей-персонажів у сучасній реалістичній прозі. Проф. Ольга Харлан та доц. Ольга Яблонська звернули увагу на аналітичність і синтетичність цієї роботи, a dr Albert Nowacki зазначив, що це солідний перегляд сучасної української прози для дітей і запропонував «у майбутньому, щоб доповнити картину дитячого книжкового ринку, зробити аналогічний перегляд перекладної літератури для дітей».

Докт. філол. наук Сніжана Жигун (Київський університет імені Бориса Грінченка) предметом наукового осмислення обрала образ дитячого будинку у творчості і житті Оксани Іваненко. Системно і цілісно літературознавець проаналізувала три повісті («Манівцями», «Рідні діти», «Весілля в монастирі») та аргументовано довела тезу про внутрішній конфлікт письменниці Оксани Іваненко, яка була переконана в потребі виховувати сиріт в умовах, наближених до родини, але мусила позірно славити ідеї соціального виховання, зокрема А. Макаренка.

Принципи екологічної взаємодії в дитячих оповіданнях Олеся Ільченка озвучила здобувач Юлія Куманська (Східноєвропейський національний університет імені Лесі Українки).

Важливу проблему антимілітарного досвіду осмислення Другої світової війни в художніх творах для і про дітей порушила докт. філол. наук, проф. Віталіна Кизилова (ДЗ «Луганський національний університет імені Тараса Шевченка»). У площині ії аналітики написані на основі спогадів про власне дитинство повісті М. Вінграновського, Г. Тютюнника, В. Рутківського, Є. Гуцала. Авторка зауважила тяглість традиції атнимілітарного показу війни у твоpax про і для дітей до і після 60-х років XX ст. і на поч. XXI ст.

Широкий об'єкт дослідження (від фольклорних зразків і до сучасної літератури) презентував у цікавій доповіді «Дитяча травма як елемент зав'язки літературного твору для дітей та юнацтва» канд. філол. наук, доц. Віктор Кисіль (Харківський національний університет імені В. Н. Каразіна).

Мотиви втраченого дитинства, дитячої травми, генераційного конфлікту дітей і батьків у текстах сучасних письменників 
Софії Андрухович, Сергія Жадана, Володимира Лиса, Ірен Роздобудько, Олега Сенцова обговорювали науковці на п'ятій сесії конференції.

Спираючись на психологічні дослідження травмованої дитячої свідомості, враховуючи специфіку впливу війни на формування індивідуальної ідентичності, доктор філол. наук, доц. Оксана Пухонська (Національний університет «Острозька академія») проаналізувала роман американсько-хорватської письменниці Сари Новіч «Дівчинка на війні». Літературознавиця називає його прикладом упровадження проблеми дитячої травми війни у ширший культурний контекст з метою актуалізації потенційних можливостей культуротерапії травмованого суспільства.

У коло наукових інтересів учасників конференції з Хорватії Dariya Pavlešen, Domagoj Kliček (Загребський університет) теж входить проблема конструювання ідентичності особистості. На основі дослідження роману Софії Андрухович «Фелікс Австрія», аналізу оповіді героїні, науковці продемонстрували, як дитячі спогади впливають на формування особистості; як феномен пам'яті, відсутність спогадів та їх конструювання може стати мотивацією подальших дій дорослої людини.

На матеріалі роману «Інтернат» Сергія Жадана кандидат філологічних наук, доцент Уляна Федорів (Львівський національний університет імені Івана Франка) окреслила вплив категорії травми на формування національної та культурної ідентичності, проаналізувала художню репрезентацію мотиву втраченого дитинства. А доктор філологічних наук, професор Ольга Новик (Бердянський державний педагогічний університет) у компаративному зіставленні цього роману із романом «Крадійка книжок» Маркуса Зузака розкрила художньо-психологічні аспекти долі дитини, яка мусить жити/ виживати/ дорослішати у часи війни, кризи.

Генераційний конфлікт дітей і батьків у травматичному ландшафті національної самоідентифікації, розгорнутий у п'єсі С. Жадана «Хлібне перемир'я", - предмет дослідження Алли Демченко (Херсонський державний університет). 
Dr Albert Nowacki (Katolicki Uniwersytet Lubelski Jana Pawła II) презентував результати системного дослідження творчості Володимира Лиса. Цього разу у центрі аналітичного дискурсу науковця - образ дитини і дитинства у повістях письменника.

3 цікавістю учасники слухали доповідь dr. Katarzyna Jakubowska-Krawczyk, яка запропонувала оригінальний ракурс інтерпретації оповідань Олега Сенцова і наголосила на художніх аспектах автобіографічного показу дитячого світу, дорослішання і формування ціннісних позицій юної особистості.

Заключна шоста сесія об'єднала науковців в обговоренні проявів дитинства у мистецьких парадигмах. Детальний огляд публіцистичних текстів часопису «Кур'єр Кривбасу» з метою виокремлення проблеми показу соціальних та політичних змін очима дитини здійснила аспірантка Херсонського державного університету Наталія Чавура. Схвальні відгуки отримала візуалізована доповідь dr. Marta Zambrzycka, присвячена проблемі втечі в інфантилізм, аналізу дискурсу дитинства як форми протиставлення в живописі вибраних художників «Паризької комуни». Інтертекстуальність як особливу ознаку літератури для дітей та молоді проаналізував Dawid Bzorek (Uniwersytet Warszawski).

Конференція вирізнялася 3-поміж подібних заходів особливою активністю учасників у віртуальному просторі: обговоренні доповідей, спілкуванні у чаті. Професор Ярослав Поліщук у підсумковій дискусії запропонував радикально переглянути радянський канон літератури для дітей та юнацтва і провести його реконструкцію. Радянська дитяча література, на думку науковця, - то соціальний утопізм, який не може мати продовження. Однак проф. Ольга Харлан заперечила повне відкидання літератури цього періоду, а проф. Тетяна Качак зауважила, що все-таки в історії української літератури для дітей варто прослідкувати тяглість традиції, наприклад, у зображенні дитинства, художній репрезентації дитячої травми чи навіть художнього представлення уже згадуваного образу дитячого притулку.

Було проговорено й питання художньої інтерпретації в літературі та культурі дихотомічних категорій дитячий\дорослий, 


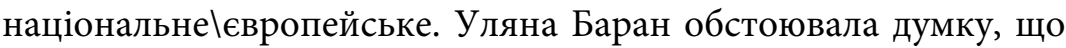
українська реалістична література для підлітків (12+) ще не відбулася як явище, на противагу німецькій чи іншим європейським літературам. Натомість Тетяна Качак продемонструвала книги сучасних українських письменників, які відповідають запитам підлітків, оскільки порушують актуальні для них проблеми, демонструють знайомі й близькі моделі поведінки героя-ровесника, і констатувала, що ця ніша достатньо заповнена якісною національною прозою.

Резонанс, який викликали доповіді учасників конференції, засвідчує, що актуальність осмислення феномена дитинства загострюється у контексті кризових ситуацій, ідеологічних, економічних, культурних, соціальних і політичних змін. Дитинство $є$ підвалиною розвитку майбутніх генерацій, показником рівня розвитку сучасного суспільства, тому важливим $€$ питання врахування і збереження його специфіки як найбільш цінного і відповідального періоду життя людини, соціокультурного феномена. Кафедра україністики не залишається осторонь ключових проблем гуманітаристики, розширює національні кордони і забезпечує європейський контекст наукових студій.

Науковці подякували організаторам за чудовий конференційний онлайн-майданчик, який, всупереч карантинним умовам, став успішною платформою для спілкування фахівців, обговорення і дискусій, зародження нових ідей та мотивації для подальших досліджень. 


\title{
Larysa Vakhnina
}

National Academy of Sciences of Ukraine (Ukraine)

ORCID: 0000-0002-1030-7140

Myroslava Karatsuba

National Academy of Sciences of Ukraine (Ukraine)

ORCID: 0000-0003-4836-9264

\section{Відзначення ювілею Максима Рильського в Інституті мистецтвознавства, фольклористики та етнології ім. М. Т. Рильського НАН України}

\section{Celebrating the anniversary of Maxim Rylsky at the Rylsky Institute of Art Studies, Folklore and Ethnology NAS, Ukraine}

\begin{abstract}
:
The article is devoted to the events of the M. T. Rylsky Institute of Art History, Folklore and Ethnology of the National Academy of Sciences of Ukraine, dedicated to the 125th anniversary of the poet-academician Maksym Rylsky, who was its director for many years, as well as analytical coverage of the issues of the international scientific conference, which took place in Kyiv on December 28, 2020, co-organized and participated by Polish scientists.
\end{abstract}

Keywords: Maksym Rylsky, anniversary, culture, conference, Ukraine, Poland.

Мета статті: показати нове бачення багатогранної постаті поета-академіка Максима Рильського в контексті ювілейних заходів Інституту мистецтвознавства, фольклористики та етнології імені М.Т. Рильського НАН України. Це стосується як нових 
видань останніх років, так і організації міжнародної наукової конференції в Києві, що відбулася 28 грудня 2020 р.

19 березня 2020 р. виповнилося 125 років від дня народження видатного українського поета та перекладача, академіка Максима Тадейовича Рильського. Його життя та науковоорганізаційна діяльність були пов'язані з Інститутом мистецтвознавства, фольклористики та етнології імені М.Т. Рильського, який з честю носить його ім'я. 1942 р. під час евакуації до Уфи Інституту українського фольклору він стає його директором, Інститут очолює до самої смерті (1964р.). Саме з ініціативи М.Т.Рильського Інститут розширює коло своїх дослідницьких інтересів, змінюється його назва - Інститут мистецтвознавства, фольклору та етнографії АН УРСР. Після Другої світової війни М.Т. Рильський чимало зробив для розвитку академічної науки, був членом Президії Академії наук України, головою Українського комітету славістів, брав участь у міжнародних з'їздах славістів, сприяючи розвитку міжнародних зв'язків українських учених. Його творча та наукова діяльність залишаються в центрі уваги вчених IМФЕ ім. М.Т. Рильського НАН України. Було видано цілий ряд наукових праць, присвячених його спадщині.

Важливою подією для дослідників та шанувальників творчого доробку Максима Рильського стала Міжнародна наукова конференція «Максим Рильський як учений та організатор науки», присвячена 125-річчю від дня народження Максима Тадейовича Рильського, яка відбулася 28 грудня 2020 року в ІМФЕ ім. М.Т. Рильського НАН України. Серед членів оргкомітету міжнародної конференції є також меморіальний музей Максима Рильського, Благодійна організація «Фонд Максима Рильського “Троянди й виноград”", а також Майстерня дослідження польсько-українських літературних зв'язків на кафедрі україністики Варшавського університету, яку очолює проф., доктор філологічних наук Валентина Соболь. До організаційного комітету конференції також увійшла відомий дослідник творчості М.Т. Рильського, польський літературознавець, доктор 
габілітований, ад’юнкт кафедри літературознавства Інституту неофілології Університету Марії Кюрі-Склодовської у Любліні (Польща) Людмила Сірик ${ }^{1}$.

28 грудня 2020 р. $з$ ранкового пленарного засідання розпочала свою роботу Міжнародна наукова конференція «Максим Рильський як учений та організатор науки», приурочена до 125 річниці від дня народження поета й науковця. Програма конференції передбачала роботу кількох тематичних блоків доповідей, присвячених різним аспектам діяльності М. Рильського. На відкритті конференції із привітальним словом виступили організатори і шановані гості заходу, зокрема директор Інституту мистецтвознавства, фольклористики і етнології ім. М.Т. Рильського академік Г.А. Скрипник, яка згодом доповнила його залученням поетичних виступів визначних українських поетів про М. Рильського протягом півгодинної перерви між пленарними засіданнями; керівник Фонду Максима Рильського «Троянди й виноград», спадкоємець поета Максим Рильський, а також директор Київського літературно-меморіального музею Максима Рильського В.Л. Колесник; доцент кафедри теорії і історії мистецтв Харківської державної академії дизайну і мистецтв, кандидат історичних наук В.А. Сушко. Основний масив наукових доповідей було представлено у виступах учасників із доповідями, заявленими на двох пленарних засіданнях, тоді конференція продовжувала свою діяльність у заочному форматі, йдеться про роботу секційних засідань, із текстами виступів учасників яких можна буде ознайомитися у збірнику наукових статей, видання яких планується у прийдешньому році.

Під час перерви учасники конференції мали змогу ознайомитися із матеріалами відеогалереї портретів М.Т. Рильського з альбому, підготовленого співробітниками Інституту. До ювілею свого патрона ІМФЕ ім. М. Т. Рильського НАН України видав друком книжку «Максим Рильський в спогадах, працях

${ }^{1}$ L. Siryk, Antropolohichna konceptsiia liudyny v poezii kyivskykh neoklasykiv [w:] „Narodna tvorchist ta etnolohiia”, 2, IMFE, Kyiv 2020, s. 28-39. 
та портретах» 2 , спецвипуск журналу «Народна творчість та етнологія». Було представлено тематично розмаїтий матеріал, приурочений до 125-річчя від дня народження М. Рильського. Це галерея портретів і біографічних фотографій митця, добірка його поезій і наукових публікацій, спогади та творчі рецепції колег і сучасників.

Привітальні виступи скерували увагу доповідачів і слухачів на значенні творчості М.Т. Рильського в українській культурі XX ст., їі відгомонах у різних мистецьких напрямках у столітті XXI, а також на творчих контактах Рильського із його визначними сучасниками.

Різні аспекти спадщини М. Рильського перебували у фокусі уваги знаних доповідачів першого пленарного засідання, робота якого тривала у першій половині дня. Так, проф. КНУ ім. Тараса Шевченка М. Стріха звернувся до вельми актуальної на сьогодні теми українізації опери у світлі діяльності М. Т. Рильського ${ }^{3}$, оперні переклади якого є гідними, аби звучати зі сцени сучасних українських театрів. Доповідач заохочував співробітників IMФЕ ім. М.Т.Рильського НАНУ (далі скорочено - ІМФЕ НАНУ) до всебічного аналізу цієї проблеми.

Праця М.Т. Рильського, видана майже 80 років тому, важлива для розуміння ключових віх української історії, присвячена темі стародавнього Києва, виступала об’єктом уваги проф. кафедри україністики Варшавського університету п. Валентини Соболь.

Співробітник ІМФЕ НАНУ, доктор мистецтвознавства Л.П. Корній звернулася до теми впливу творчого середовища на формування яскравої особистості на прикладі представників родини Рильських - Тадея і Максима - і знакового українського композитора М. Лисенка. Слід відзначити цю доповідь як таку,

${ }^{2}$ Maksym Rylskyi u spohadakh, pratsakh ta portretakh (do 125-richchia vid dnia narodzhennia). Albom. NASA Ukraine, IMFE im. M.T. Rylskoho. Holovnyi redaktor H. A. Skrypnyk, IMFE, Kyiv 2019, 244 s. + III іл.

${ }^{3}$ M. Strikha, Maksym Rylskyi - perekladach opernykh libretto: literaturnyi, mysteckyi, natsiietvorchyi vymiry, Vidpovidalnyi redaktor V. Kuzyk, IMFE, Kyiv 2020. 
що висвітлює спадкоємність традицій українського мистецтва. У певному аспекті суголосною із цією темою була й доповідь доцента Поліського університету Г. Махоріна (м. Житомир), який визначив як показову рису творчої вдачі Максима Рильського у контексті його родоводу спадкоємність любові до українського народу. Тезу було проілюстровано на прикладах із репрезентованих доповідачем грунтовних збірників статей і спогадів, серед них найяскравіший - «У світлі слави Рильських».

Завідувач відділу ІМФЕ НАНУ проф. Л. К. Вахніна у своїй доповіді звернулася до однієї з базових проблем сучасної славістики - значення наукової діяльності М.Т. Рильського як одного з фундаторів української славістичної науки, організатора і учасника міжнародних з'їздів славістів ${ }^{4}$.

Важливою складовою засідання виступає звернення доповідачів до важливого питання - особистих, творчих і наукових контактів М.Т. Рильського з вітчизняними діячами культури і науки. Так, особисті і творчі контакти Рильського із визначними науковцями доби, зокрема знаним літературознавцем О. Білецьким, були темою виступу провідного наукового співробітника ІМФЕ НАНУ Т.П. Рудої, автора книжки «Максим Рильський: грані великого таланту» (Київ, 2017)5. Дружні взаємини корифеїв української культури зі сфер поетичного і музичного слова М. Рильського, Дмитра й Левка Ревуцьких постають в усій повноті у грунтовній доповіді фахівця-музикознавця, старшого наукового співробітника IМФЕ НАНУ В. Кузик. Суголосся геніїв М. Рильського і О. Довженка опиняється у центрі уваги виступу визначного українського кінознавця, старшого наукового співробітника ІМФЕ НАНУ С.В. Тримбача. Доповідач звертається до фактів, пов'язаних зі знайомством письменників, що відбулося понад сто років тому, аналізує значення заяв на захист

${ }^{4}$ L. Vakhnina, Do yuvileiu Maksyma Rylskoho, Mystetstvo ta osvita, Kyiv 2020, s. 60-61.

5 T. Ruda, Hrani velykoho talantu: Maksym Rylskyi - poet, perekladach, uchenyi, Holovnyi redaktor H. A. Skrypnyk., IMFE, Kyiv 2017. 
О. Довженка з боку М. Рильського, участь М. Рильського у дискусії стосовно виходу фільму «Поема про море» тощо.

До проблеми спадкоємності і близькості наукових традицій звертається провідний науковий співробітник ІМФЕ НАНУ О.О. Микитенко, простежуючи шляхи української лексикології та проблем наукового перекладу на яскравих прикладах наукових шкіл, пов'язаних із постатями М.Т. Рильського, Л.А. Булаховського і Й.А. Багмута.

На питання: чи можна інтерпретувати фільм через наратив, дає відповідь п. А. Ганжа, старший науковий співробітник Інституту української мови НАН України, звертаючись до Ірунтовного аналізу змісту і передісторії створення фільму, де представлено творчу постать М. Рильського, - «Poeta Maximus» (2008).

«Максим Рильський у відлуннях дискурсів Голосіївського парку» - у такий спосіб прозвучав творчий геній поета у світлі бачення М.Й. Хая, провідного наукового співробітника ІМФЕ НАНУ. Голосієво як місцевість-колиска, своєрідна захисна аура цієї місцевості і споруда на вулиці Грушевського (приміщення ІМФЕ НАНУ), органічно пов'язана із родиною Рильського, погляд сучасних діячів культури на творчу постать М. Рильського як «латентного дисидента» (термін запропонований у виступі) - основні творчі напрямки-тези доповідача.

Друга частина пленарного засідання розпочалася після перерви о 14.00 із доповіді проф. Київського національного університету ім. Тараса Шевченка М.К. Наєнка, присвяченої участі М. Рильського як свідка у сфабрикованій справі Спілки визволення України, де планувалося засудження 45 учасників. Доповідач детально описує свідчення М. Рильського, його оцінку діяльності учасників справи - неокласиків, фігурантів «Ланки» $\mathrm{i}$ «ВАПЛІТЕ».

Звернення до творчої постаті Максима Рильського, відповідно до концепції висвітлення особистості на сторінках «Української музичної енциклопедії», підготовленої співробітниками ІМФЕ НАНУ, стає об'єктом уваги яскравої доповідачки, старшого наукового співробітника-музикознавця з IMФЕ НАНУ - І. Сікорської. Своєрідним тематичним продовженням 
цієї доповіді був виступ доктора мистецтвознавства, професора ДВНЗ «Прикарпатський національний університет імені Василя Стефаника» (Івано-Франківськ), яка звернулася до солоспівів композиторів (детально увагу приділено музичним зразкам «Марія», «На білу гречку впали роси», «Моряк»), представників української діаспори, підготовлених на базі текстів М.Т. Рильського.

Постать М. Рильського як перекладача з сербської народної поезії виступає у руслі дослідницької уваги старшого наукового співробітника ІМФЕ НАНУ М. Карацуби. Доповідачка охарактеризувала художні переклади Рильським сербської народної поезії як досконале відтворення оригіналу в максимальному наближенні до нього щодо стилю, жанру, характеру образності, навіть при певних, неминучих перестановках - шляхом компенсації образу.

Природа і пам’ятки культури у життєтворчості М.Т. Рильського постають як «територія свободи» у грунтовній, прекрасно ілюстрованій слайдами доповіді старшого наукового співробітника ІМФЕ НАНУ Л. Босої.

Науковий співробітник ІМФЕ НАНУ О. Летичевська звернулася до історії листа М. Рильського з особистого архіву актриси Н. Гебдовської. Свою доповідь авторка ілюструвала фотографіями, слайдами архівних документів.

Духовні пошуки та аксіологія М. Т. Рильського опинилися у фокусі дослідницької уваги харківських гостей з Академії неперервної освіти (доповідачі В. Чуркіна, Г. Вороніна).

Християнська тематика (тема прощення, образ сонця-світла, образ Богоматері, образ гордині, образ воскресіння тощо) у поезії митця виступала об’єктом уваги молодшого наукового співробітника ІМФЕ НАНУ О. Прилепи.

Наукова співробітниця І. Лісняк (ІМФЕ НАНУ) звертається до кобзарської тематики у творчості М. Рильського, аналізує думовий епос у світлі зацікавлень М. Рильського.

М.Т. Рильський і функціонування часопису «Народна творчість та етнографія» - тема останнього виступу другого 
пленарного засідання, виголошена С. Василик, молодшим науковим співробітником IМФЕ НАНУ.

Тематикою секційних засідань конференції було передбачено розгляд широкого спектру проблем народознавчого, мистецтвознавчого та культурологічного спрямування.

Зауважимо, що робота засідань проходила дуже плідно, було виголошено чимало доповідей, значення яких для розуміння творчого феномену постаті М. Рильського не варто применшувати. У конференції взяло участь чимало знаних науковців-рильськознавців, чиї доповіді збагатили науковий арсенал IMФЕ НАНУ. Серед польських вчених слід також відзначити, крім уже згаданих виступів Валентини Соболь (Варшава) і Людмили Сірик (Люблін), також цікаві доповіді Василя Назарука (Варшава) та Ярослави Конєвої (Ольштин). Участь польських науковців є символічною, адже Максим Рильський відомий не тільки як майстерний перекладач «Пана Тадеуша» Адама Міцкевича, його величезні заслуги і як дослідника польської культури та українсько-польських культурних взаємин було відзначено високим званням Почесного Доктора Ягеллонського університету, а також польських державних нагород.

Модераторами конференції, яка відбувалася онлайн, були директор ІМФЕ ім. М.Т. Рильського НАН України, академік Ганна Скрипник, та завідувач відділу української та зарубіжної фольклористики Лариса Вахніна.

Висновки: Хотілося відзначити високий науковий рівень конференції, висловити подяку їі організаторам і найкращі побажання творчих успіхів їі численним учасникам як в Україні, так i за їі межами. Виголошені доповіді та наукові дискусії стануть не тільки новим внеском в дослідження спадщини видатного поета і науковця, а й відкриють для дослідників та шанувальників його творчості маловідомі чи призабуті сторінки його життєвого шляху, сприятимуть розвитку українсько-польських наукових та культурних взаємин. В інституті з нагоди ювілею М.Рильського відкрито меморіальну кімнату поета-академіка. 


\section{References}

Maksym Rylskyi u spohadakh, pratsakh ta portretakh (do 125-richchia vid dnia narodzhennia). Albom. NASA Ukraine, IMFE im. M. T. Rylskoho. Holovnyi redaktor H. A. Skrypnyk, IMFE, Kyiv 2019, 244 s. + III іл.

Ruda T., Hrani velykoho talantu: Maksym Rylskyi - poet, perekladach, uchenyi. Holovnyi redaktor H. A. Skrypnyk., Vydavnytstvo IMFE, Kyiv 2017.

Strikha M., Maksym Rylskyi - perekladach opernych libretto: literaturnyi, mystetskyi, natsiietvorchyi vymiry. Vidpovidalnyi redaktor V. Kuzyk. IMFE, Kyiv 2020.

Siryk L., Antropolohgichna koncepcijia ludyny v poeziji kyivskikh neoklasykiv [w:] «Narodna tvorchist ta etnolohiia», 2. IMFE, Kyiv 2020.

Vakhnina L. K., Do yuvileiu Maksyma Rylskoho, Mystetstvo ta osvita, Kyiv 2020, s. $60-61$. 


\section{Teresa Chynczewska-Hennel}

University of Białystok (Poland)

ORCID: 0000-0002-9847-4540

\section{Profesor Ihor Skoczylas (5 IV 1967 - 20 XII 2020)}

\section{Professor Ihor Skochylas (5 IV 1967 - 20 XII 2020)}

\section{Abstract:}

This article is written in memoriam of Ihor Skochylas, a historian and outstanding researcher. In 1993 he graduated from the Ivan Franko National University of Lviv. He worked at the Academy of Sciences of Ukraine and then at the Ukrainian Catholic University in Lviv. He was visiting professor at the Ukrainische Freie Universität in Munich. He is the author of 250 scientific publications on the history of the Ternopil region and, above all, the history of the Church in Ukraine in the broader perspective of the history of the First Republic and in connection with the universal Church. Innovative research by Ihor Skoczylas is related to the search for a "mental map". The book by Ihor Skoczylas, co-authored with A. Gil, entitled "Eastern Churches in the Polish-Lithuanian state" (Lublin-Lviv 2014).

Keywords: Ihor Skochylas, in memoriam, Lviv, historian.

Nigdy nie pomyślałam, że Ihor odejdzie tak wcześnie. Braliśmy ostatnio wspólnie udział w Międzynarodowej Konferencji zorganizowanej przez Uniwersytet Papieski Jana Pawła II w Krakowie, w dniach 18-19 listopada 2020 roku. Tematem konferencji było „Dziedzictwo Synodu Zamojskiego 1720-2020. Wyzwania i perspektywy”. Dyskutowaliśmy w gronie naukowców zajmujących się problematyką wyznaniową w dawnej Rzeczypospolitej oraz w czasach współczesnych. Referenci reprezentowali uczelnie z Polski, Włoch, Ukrainy i Białorusi. Ponieważ to czasy pandemii, większość uczestników połączyła się z organizatorami dzięki formatowi on - line. Jesteśmy od prawie już roku przyzwyczajeni do tego typu kontaktów, 
w ten sposób odbywają się zajęcia ze studentami, egzaminy, rady naukowe, obrony prac doktorskich i spotkania konferencyjne. Kiedy zobaczyłam na ekranie komputera mojego Kolegę ze Lwowa, wróciły wspomnienia naszych spotkań kongresowych, konferencyjnych i koleżeńskich z Warszawy, Rzymu, Lwowa, Kijowa.

Pamiętam dobrze Jego odwiedziny w moim domu, razem z profesorem Andrzejem Gilem przy kawie rozmawialiśmy o perspektywach współpracy historyków polskich i ukraińskich. Patrzyliśmy z okna mojego pokoju zatłoczonego książkami i papierami w dal - na las. Nas już nie będzie, ale las będzie rósł - nie pamiętam, kto wówczas wypowiedział to. Las - ileż symboliki kryje w sobie to słowo - pierwszy dom człowieka, schronienie duszy, miejsce istot nadprzyrodzonych, ratunek dla naszej planety... Rozszerzać można tę symbolikę niemal w nieskończoność. Ale wówczas nie uświadamialiśmy sobie, w jak nieoczekiwany sposób, niezrozumiały wtedy dla nas, czas bezlitośnie przyspieszy.

Gawędziliśmy sobie w przerwach tej ostatniej wspólnej konferencji, ja w Warszawie w moim mieszkaniu, Ihor we Lwowie. Opowiadał o swojej i swoich kolegów pracy, o tym, że mimo zagrożenia Covidem czują się wszyscy dobrze.

Minął miesiąc od tamtego spotkania. Wiadomość o Jego śmierci dotarła nagle, niespodziewanie, okrutnie, bez jakiegokolwiek zrozumiałego tu na ziemi sensu. Ihor odszedł zaatakowany przez działanie bezwzględnie niszczącego wirusa.

Młody, w pełni sił do dalszego życia i działania - pozostawił swoją zrozpaczoną rodzinę, bliskich, przyjaciół, kolegów.

Ihor Skoczylas (Skochilyas) urodził się 5 kwietnia 1967 roku w Cyganowie, w powiecie Borszczów, w obwodzie Tarnopolskim. Wówczas Ukraina znajdowała się w ZSRR. Ihor przeżywał bardzo, jak wszyscy jego rodacy, ogromną radość z odzyskania niepodległości, cenił ją i przestrzegał swoich uczniów, że nie wolno jej już nigdy utracić. Od najmłodszych lat interesował się historią, uważał, że historia powinna uczyć ludzi, jak bardzo ważna jest wolność narodów i każdego pojedynczego człowieka. Jego Alma Mater to Lwowski Uniwersytet Narodowy imienia Iwana Franki, na którym ukończył 
w roku 1991 z wyróżnieniem kierunek historyczny. Zaangażował się, jeszcze w czasach studenckich w działalność lokalnego towarzystwa propagującego wiedzę historyczną i został rychło współzałożycielem Towarzystwa „Dzherelo” (Borszczow) oraz współredaktorem „Kroniki Borszczowa”. W latach 1992-1995 był członkiem Rady Redakcyjnej naukowego zbioru „Ukraina w przeszłości” a także Przewodniczącym Zespołu Historycznego i członkiem Komisji Archeologicznej Naukowego Towarzystwa Szewczenki. Był też członkiem Ukraińskiego Towarzystwa Heraldycznego.

Profesor Ihor Skoczylas od 1993 roku pracował naukowo w Instytucie Archeografii Ukraińskiej i Źródłoznawstwa Narodowej Akademii Nauk Ukrainy we Lwowie przechodząc przez kolejne szczeble naukowe. Od roku 1999 pracowal jako wykładowca, a od 2020 roku był kierownikiem Katedry Historii Kościoła w Ukraińskim Katolickim Uniwersytecie. Od roku 2010 pełnił funkcję Dziekana Wydziału Nauk Humanistycznych na tej Uczelni, w 2016 roku został także prorektorem do spraw nauki.

W latach 2013-2015 był profesorem wizytującym (Visiting Professor) w Ukraińskim Wolnym Uniwersytecie w Monachium (Ukrainische Freie Universität).

Dorobek naukowy Profesora Skoczylasa jest imponujący, ponad 250 artykułów, opracowań dotyczących historii regionu Tarnopola, historii Kościoła na Ukrainie w zawsze szerokim ujęciu widzenia tego zagadnienia z perspektywy Rzeczypospolitej i związków z Kościołem powszechnym. Swoje prace publikował $\mathrm{w}$ języku ukraińskim, angielskim, włoskim, litewskim, polskim i rosyjskim.

Językiem polskim i włoskim, wiem $\mathrm{z}$ doświadczenia, bo w tych językach z Nim rozmawiałam, posługiwał się bez najmniejszego błędu i akcentu. Widać było od pierwszych słów w rozmowie, że miał niewątpliwy, nie dany wszystkim talent lingwistyczny, ale miał też coś znacznie ważniejszego. Był obdarzony ogromną elegancją w sposobie wypowiadania, pisania i przede wszystkim oznaczał się widoczną dla nas kolegów szlachetnością charakteru.

Nie miejsce tu, w tym smutnym wspomnieniu wymienić choćby najważniejsze Jego publikacje. Nie można jednak pominąć 
na przykład monografii z 2004 roku opublikowanej we Lwowie Heneralni vizytatsii Kyivskoii uniinoii mytropolii XVII-XVIII stolit: Lvivsko-Halycko-Kamianecka yeparkhiia, T. 2.

Znając doskonale archiwalia rzymskie, które wykorzystywał w swych pracach Profesor Skoczylas, powstawały publikacje oryginalne uwzględniające szeroki wachlarz źródeł. Wiele nowego wnosiły książki i artykuły dotyczące także wizytacji kościołów i klasztorów diecezji włodzimierskiej z końca XVII i początku XVIII wieku. Współpraca z polskim historykiem, profesorem Andrzejem Gilem układała się pomyślnie, przynosząc w efekcie cenne pozycje. Pragnę tu zwrócić uwagę na obszerne studium obu Autorów, na książkę Kościoły Wschodnie w państwie polsko-litewskim w procesie przemian i adaptacji: Metropolia Kijowska $w$ latach 1458-1795, (Instytut Europy Środkowo-Wschodniej, Lublin-Lwów 2014). Pozycja ta była recenzowana przez piszącą te słowa na łamach naszego Rocznika ${ }^{1}$. Należy zwrócić uwagę, iż Autorzy wykorzystali w pracy nad historią Kościołów Wschodnich - prawosławnego i unickiego (greckokatolickiego) w omawianym okresie, rozumianym jako okres przemian i adaptacji w państwie polsko - litewskim, bogaty materiał źródłowy, drukowany i rękopiśmienny z archiwów polskich, ukraińskich, litewskich i rosyjskich. Charakterystyczne i nowatorskie zarazem w badaniach Profesora Ihora Skoczylasa było zawsze poszukiwanie „mentalnej mapy”, rozumianej jako szerokiej przestrzeni wiernych, tej której nie uwzględniają dawne podziały administracyjne, mające wpływ na nasze rozumienie podziałów kształtowane przez widzenie map. A przecież zdaniem Uczonego postrzeganie odległych miejsc i przestrzeni wokół zmieniało się z czasem i dlatego rozumienie istoty takich wyobrażeń można dostrzec właśnie dzięki konceptowi „mapy mentalnej”.

${ }_{1}$ T. Chynczewska - Hennel, Andrzej Gil, Ihor Skoczylas, Kościoły Wschodnie w państwie polsko - litewskim w procesie przemian i adaptacji: Metropolia Kijowska w latach 1458-1795, Instytut Europy Srodkowo - Wschodniej, Lublin - Lwów 2014, ss. 683, „Studia Polsko - Ukraińskie”, Warszawa 2015, 2, s. 195-200. 
To, co bardzo ważne podkreślenia w pracach Ihora Skoczylasa, to niezgoda na widzenie Kijowa, tradycji Rusi Kijowskiej i kijowskiego chrześcijaństwa narzucanej przez propagandę rosyjską, ściśle zresztą dla celów politycznych nie przecież dla wrażliwości historycznej czy religijnej. Rzetelna analiza historyczna, głęboka znajomość przeszłości, prawdziwa naukowa refleksja - to powinność każdego prawdziwego historyka. I to przesłanie przewija się w badaniach historycznych Profesora Skoczylasa.

Ihor Skoczylas był laureatem wielu nagród i wyróżnień również w Polsce. Jego prace wysoko zawsze oceniano. Recenzowana na łamach „Studiów Polsko - Ukraińskich książka Ihora Skoczylasa i Andrzeja Gila uzyskała prestiżową nagrodę Wydawców Katolickich „Feniks” w Warszawie w roku 2015.

Profesor Ihor Skoczylas zmarł 20 grudnia 2020 roku - w pełni sił twórczych, zawodowych, pozostawił nas wszystkich bliskich w ogromnym żalu. Będziemy o Tobie pamiętać i o lesie, by tam móc pomilczeć wśród drzew i pomedytować o sprawach godnych i mądrych dobrego Człowieka - tak jak czynił to Horacy (Listy 1.4.4).

\section{References}

Chynczewska - Hennel T., Gil A., Skoczylas I., Kościoly Wschodnie w państwie polsko - litewskim $w$ procesie przemian i adaptacji: Metropolia Kijowska w latach 1458-1795, Instytut Europy Środkowo - Wschodniej, Lublin - Lwów 2014, ss. 683, „Studia Polsko - Ukraińskie”, Warszawa 2015, 2, s. 195-200. 
www.wuw.pl 